ANGELA DENISE GRATÃO AMORIM

\title{
A mediação da informação contábil sob a ótica da ciência da informação
}

São Paulo - SP 


\section{ANGELA DENISE GRATÃO AMORIM}

\section{A mediação da informação contábil sob a ótica da ciência da informação}

Tese apresentada ao Departamento de Biblioteconomia da Escola de Comunicação e Artes da Universidade de São Paulo pelo Programa de Pós-graduação em Ciência da Informação como pré-requisito para a obtenção do titulo de doutora.

Área de concentração: Ciência da Informação e Documentação.

Linha de pesquisa: Análise Documentária Orientadora: Prof. Dra. Nair Yumiko Kobashi

São Paulo - SP 
Folha de Aprovação 


\section{AGRADECIMENTOS}

Gostaria de expressar minha gratidão às entidades pesquisadas, representadas pelos seguintes entrevistados:

UNIBANCO, Leandro Alves da Silva e Nira Bessler;

ULTRAPAR, Fernanda Leme Brasil e Maristela Seiler;

BANCO ITAÚ, Geraldo Soares;

BANCO BRADESCO, Jean Felipe Leroy e Edna R. Santos;

PETROBRAS, Marcus Vinícius Guimarães.

Meu reconhecimento à edificante orientação da Professora Doutora Nair Yumiko Kobashi.

Com apreço quero agradecer as sugestões da Professora Doutora Asa Fujino, presente em minha banca de qualificação e defesa final.

Especial admiração de longa data ao Professor Doutor L. Nélson de Carvalho, presente em minha banca de qualificação e defesa final.

De coração agradeço a meu marido, meu melhor amigo, Eduardo Ribeiro Amorim e a meu Deus, absoluto e perfeito.

Também quero mencionar a ajuda fundamental de minha amiga bibliotecária Lúcia Sassaki, orientadora extra-oficial e de meus familiares: Sr. Dario Benedicto Amorim, Gabriella M.R. Amorim e Isabel M.R. Amorim, sem os quais esta tese não seria concluída. 
Todas as leis protetoras são ineficazes, para gerar a grandeza econômica do país, todos os melhoramentos materiais são incapazes de determinar a riqueza, se não partirem da educação popular, a mais criadora de todas as forças econômicas, a mais fecunda de todas as medidas financeiras.

Obras Completas de Rui Barbosa, v. 10, t. 1, p. 143, 1883.

Fonte: Fundação Casa de Rui Barbosa, Rio de Janeiro. Disponível em: <http://www.casaruibarbosa.gov.br>. Acesso em: 1 maio 2003 
RESUMO

As companhias abertas, por meio de seus departamentos de Relações com investidores, oferecem serviços de informação, dedicados à construção de significados para usuários de divulgações contábil-financeiras. Esses serviços foram, nesta pesquisa, estudados como mediação institucional.

O estudo sobre a transferência de informações contidas nos relatórios contábeis e sua mediação permitiu a congregação interdisciplinar entre a Teoria da Contabilidade, especificamente em sua função comunicativa, e a Ciência da Informação.

Os objetivos estabelecidos foram: relacionar os serviços informacionais gerados pelas companhias abertas aos paradigmas de transferência de informações de domínios específicos, estabelecidos nas Teorias da Comunicação e Informação; apresentar e analisar as práticas de mediação institucional realizadas pelas empresas estudadas; e apresentar alternativas que pudessem aprimorar os processos de comunicação de informações contábil-financeiras.

A pesquisa de campo escolhida foi um estudo de casos múltiplos, aplicado em cinco empresas com setores de Relações com Investidores reconhecidos e teve como metodologia uma análise triangular envolvendo a empresa, seu ambiente de sociedade anônima e o macro ambiente sócio-econômico. As unidades de análise foram estabelecidas com base nas principais áreas de pesquisas em Ciência da Informação.

Como generalizações, observou-se que os relatórios contábeis constituem um conjunto voltado ao público externo à empresa e com domínio da linguagem de especialidade. A mediação tem forte embasamento na interatividade com os usuários e não há barreiras de armazenamento de informações. O crescimento dos serviços informacionais está relacionado aos atributos de relevância, conforme definido na Ciência da Informação, e na confiança conquistada. Entre outros resultados, a pesquisa também trouxe, para ser inserido nas pesquisas e aplicações da Ciência da Informação, o conjunto de características qualitativas da informação, cunhado pela Teoria da Contabilidade. 


\section{ABSTRACT}

The public corporations, by means of their investor relations departments, offer information services devoted to the construction of meaning for financial disclosure users. These services were, in this research, studied as institutional intermediation.

The study on information transference present in the accounting reports and their intermediation allowed for the interdisciplinary combination of the Accounting Theory, especially its communicative function, and the Information Sciences.

The established goals were: a) to relate the information services generated by the public corporations to the information transference paradigms in specific domains, according to the Communication and Information Theories; b) to introduce and to analyze the institutional intermediation practices by the studied companies; and c) to introduce alternatives that could improve the financial disclosure process.

The chosen field research was a study of multiple cases, applied in five companies with renowned investor relations departments and used a triangular analysis methodology involving the company, its corporate environment and its macro social and economic environments. The analysis units were established based on the main research areas according to the Information Sciences.

As a rule, it was observed that the accounting reports constitute a set of information oriented to the external public with the command of the special languages. The intermediation is strongly based on the interactivity with the users without any information storage barriers. The information services growth is related to the relevance attributes, as defined by the Information Sciences, and on trust. Among other results, the research also showed the set of qualitative information characteristics, coined by the Accounting Theory, to be inserted in the forthcoming Information Sciences researches and applications. 
SUMÁRIO

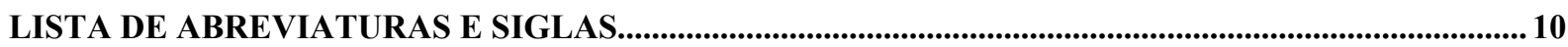

SEÇÃO 1: INTRODUÇÃO.................................................................................................................................. 1

SEÇÃO: 2. REFERENCIAL TEÓRICO E CONTEXTO INSTITUCIONAL .................................................6

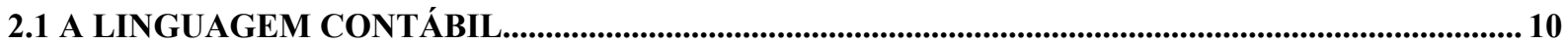

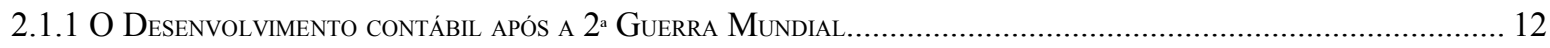

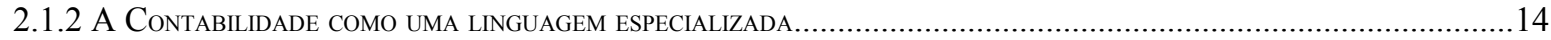

2.2 CONCEITOS DE CIÊNCIA DA INFORMAÇÃO RELACIONADOS AO TEMA..................................... 17

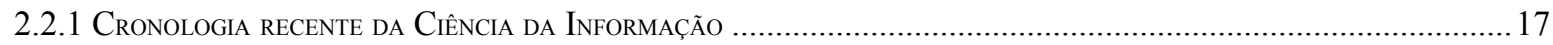

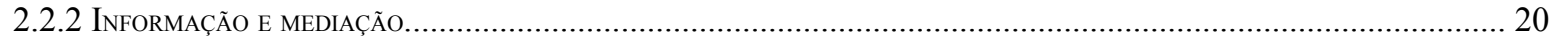

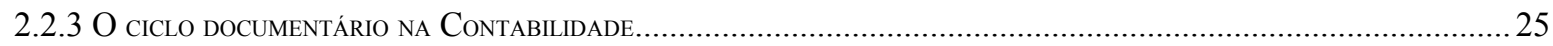

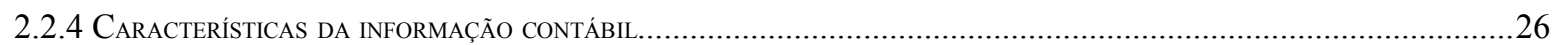

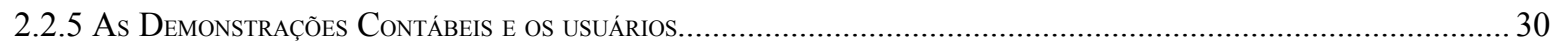

2.3 A MEDIAÇÃO INSTITUCIONAL DE INFORMAÇÕES CONTÁBEIS................................................. 32

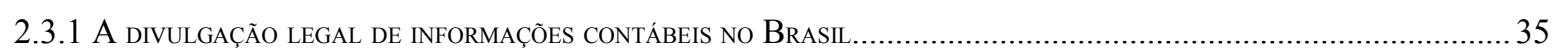

2.4 O SISTEMA FINANCEIRO NACIONAL .....................................................................................................36

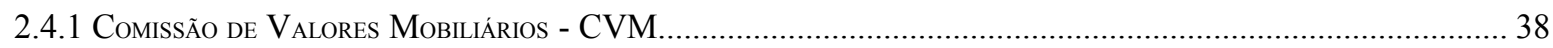

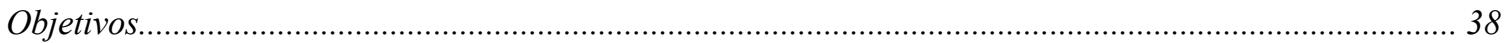

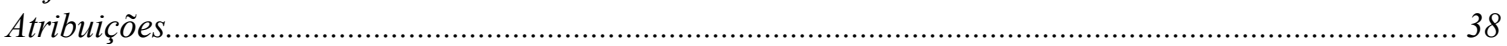

O trabalho da CVM relacionado à divulgação de informações contábil-financeiras..................................39

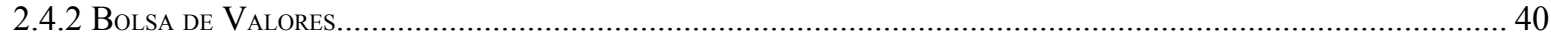

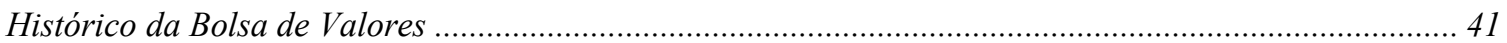

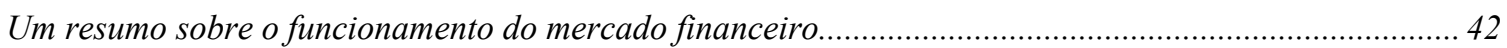

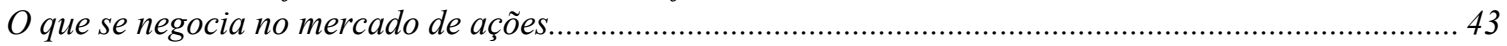

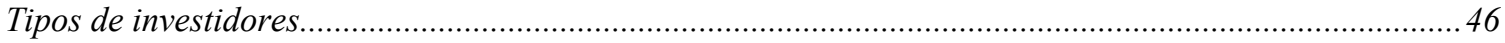

SEÇÃO 3: ANÁLISE DESCRITIVA DAS "RELAÇÕES COM INVESTIDORES".................................... 47

3.1 CONCEITO E FINALIDADE DAS RELAÇÕES COM INVESTIDORES.........................................47

3.2 A CONSTITUIÇÃO DA FUNÇÃO RELAÇÕES COM INVESTIDORES NAS EMPRESAS...............50

3.3 FUNDAMENTOS DE UM PROGRAMA DE RELAÇÕES COM INVESTIDORES..............................52

3.3.1 ObJetivos Para um PRograma de RelaÇÕes com InVESTIDORES....................................................................53

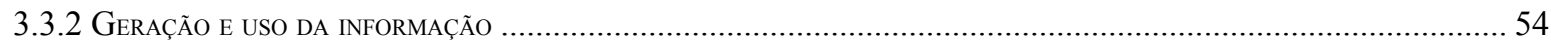

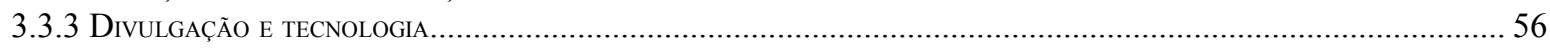

3.4 O ENFOQUE DA VALORIZAÇÃ

3.5 AS INFORMAÇÕES RELEVANTES..........................................................................................................63

SEÇÃO 4: APRESENTAÇÃO DA PESQUISA DE CAMPO.........................................................................66

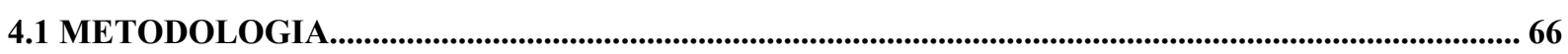

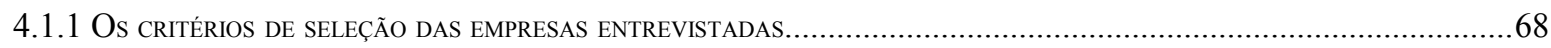

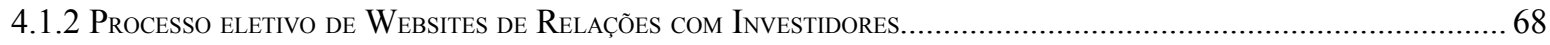

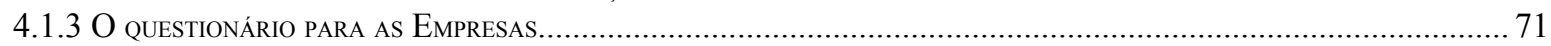

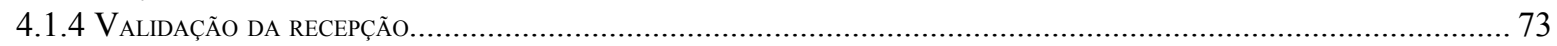

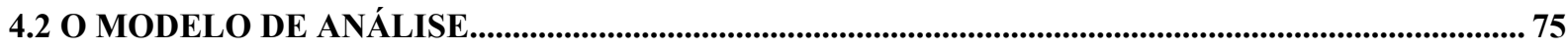

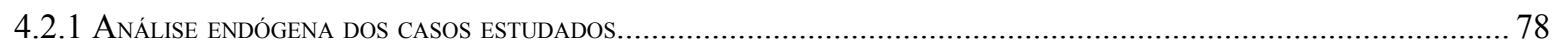

4.2.2 ANÁLISE DE REPRESENTAÇÃO E TRANSFERÊNCIA DA INFORMAÇÃO

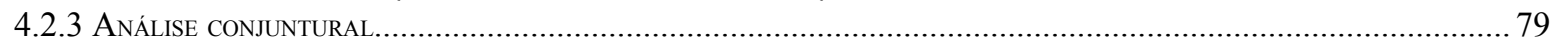

4.3 INTEGRAÇÃO DA CIÊNCIA DA INFORMAÇÃO E DA MEDIAÇÃO DAS INFORMAÇÕES CONTÁBEIS. 
SEÇÃO 5: ANÁLISE INTERPRETATIVA E CONSIDERAÇÕES FINAIS....................................................80

5.1 ANÁLISE ENDÓGENA DOS CASOS ESTUDADOS.................................................................................... 80

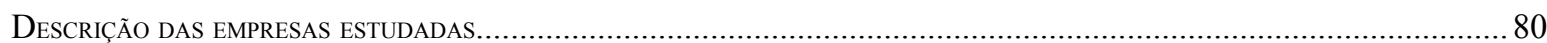

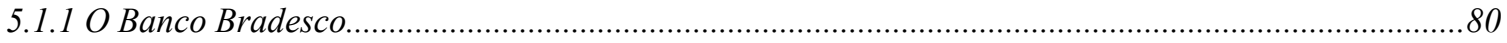

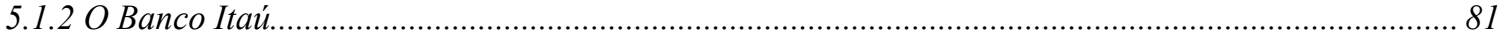

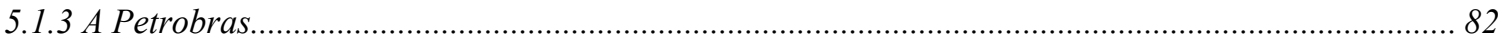

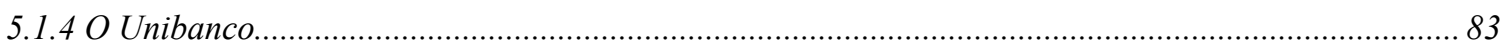

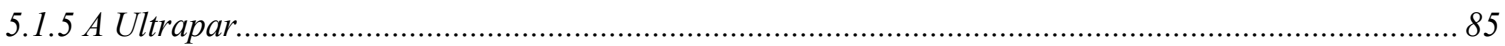

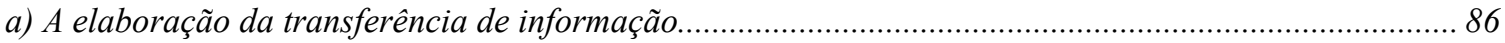

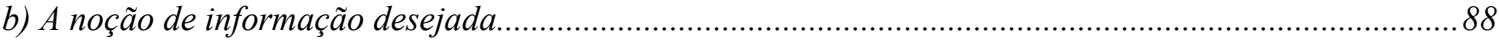

5.2 ANÁLISE DE REPRESENTAÇÃO E TRANSFERÊNCIA DA INFORMAÇÃO.................................. 89

a) Informação e produtor: a geração e a representação da informação................................................... 90

b) Eficácia dos sistemas de informação........................................................................................ 92

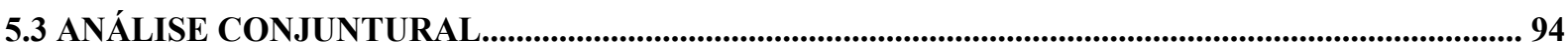

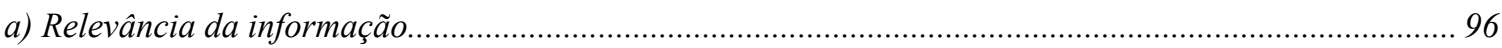

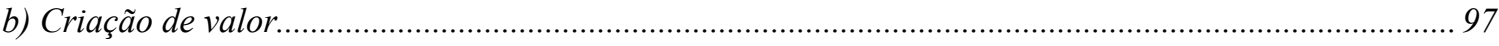

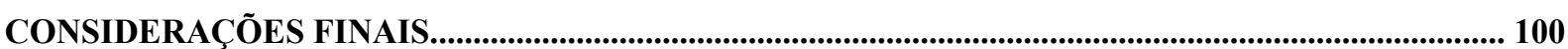

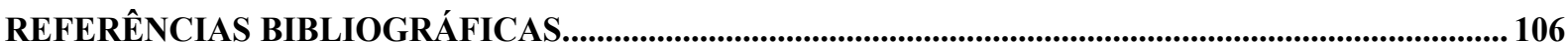

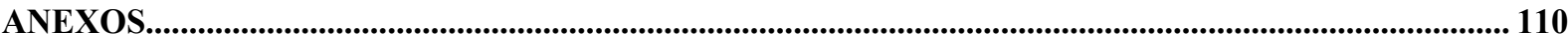




\title{
Lista de abreviaturas e siglas
}

\author{
APIMEC Associação dos Profissionais do Mercado de Capitais \\ BOVESPA Bolsa de Valores de São Paulo \\ CVM Comissão de Valores Mobiliários \\ IASB International Accounting Standards Board \\ SEC Security Exchange Commission \\ SFN Sistema Financeiro Nacional \\ IBGC Instituto Brasileiro de Governança Corporativa \\ ANIMEC Associação Nacional de Investidores do Mercado de Capitais
}




\section{Seção 1: Introdução}

Esta pesquisa tem como tema a comunicação das informações contábeis geradas pelas companhias abertas, com enfoque nas formas de mediação institucional por elas adotadas.

Nas últimas décadas, as companhias abertas - empresas que podem negociar suas ações na Bolsa de valores - começaram a prover serviços de construção de significado para as informações técnicas destinadas ao mercado investidor.

Há, desse modo, um aumento relevante de serviços informacionais prestados pelas companhias abertas. Um estudo sobre a prática da evidenciação de informações não obrigatórias nas Demonstrações Contábeis das empresas brasileiras revelou que, em 2003, 75\% das empresas pesquisadas publicaram esse tipo de informação juntamente com as legalmente obrigatórias (Colares e Ponte, 2003).

Além do aumento da chamada "evidenciação voluntária" por parte das companhias abertas, diversas entidades relacionadas ao mercado de capitais - como a Associação dos Analistas e Profissionais de Investimento do Mercado de Capitais (APIMEC), Instituto Brasileiro de Governança Corporativa (IBGC) e o Instituto Brasileiro de Relações com Investidores (IBRI) - têm buscado ampliar o conhecimento sobre o mercado de capitais e aumentar o número de associados por meio de diversos mecanismos comunicacionais.

Os usuários também estão crescendo e se diversificando. A Bolsa de Valores de São Paulo (Bovespa) vem criando, do mesmo modo, diversos mecanismos para aumentar o número de investidores, especialmente pessoas físicas, como o "Projeto Educar", "Bovespa vai à praia", "Iniciantes" etc. A mesma instituição atingiu, em janeiro de 2006, o maior número de negociações já realizadas até então - 35.952 pontos alcançados em um único pregão e o volume negociado atingindo a marca de $R \$ 2,5$ bilhões. Os Clubes de Investimento, que representam investidores que se unem para aplicar suas reservas no mercado de capitais, vêm crescendo vigorosamente - em janeiro de 2000 havia 186 clubes em atividade e no ano de 2005, no mesmo mês, foram registrados 1.066 deles. Estes grupos estão entre os 
diversos usuários das informações contábeis que ainda não estão descritos em pesquisas, embora a divulgação seja igualmente dirigida a eles.

O estudo sobre a transferência de informações contidas nos relatórios contábeis e sua mediação requer uma articulação interdisciplinar. O desenvolvimento da comunicação entre os fornecedores dessas informações e seus usuários exige, mais que nunca, descrições e análises mais elaboradas.

Esta pesquisa aborda um produto recente de mediação da informação, entendendo "mediação" como a criação do significado. São formas de construção, comunicação e uso da informação, que vêm sendo utilizadas por diversas grandes empresas. De forma mais precisa, foi estudada a diversificação dos serviços informacionais das companhias abertas, por meio de abordagem interdisciplinar entre a Ciência da Informação e a Teoria da Contabilidade. De forma mais precisa, será estudada a mediação institucional que ocorre nas companhias abertas por meio de seus departamentos de "Relações com Investidores". A revista RI (Relações com Investidores) $n .^{\circ}$ 66, de agosto de 2003, define a expressão "relações com investidores":

É o conjunto de atividades, métodos, técnicas e práticas que, direta ou indiretamente, propicie a interação das áreas de Contabilidade, Planejamento, Comunicação, Marketing e Finanças, com o propósito de estabelecer uma ligação entre a administração da empresa, os acionistas (e seus representantes) e os demais agentes que atuam no mercado de capitais e que integram a comunidade financeira nacional ou internacional.

A falta de conhecimento do contexto do uso das informações contábeis e de construção de sentido para o usuário tem como resultado um distanciamento entre a emissão e a recepção dessas informações. O governo, ao exigir a abertura de informações contábeis das empresas, faz isso sem considerar as limitações de compreensão decorrentes do alto nível de especialidade da linguagem contábil. De fato,

Um dos grandes desafios da Contabilidade, relativamente à evidenciação, tem sido o dimensionamento da qualidade e da quantidade de informações que atendam às necessidades dos usuários das demonstrações contábeis em determinado momento. Como parte do esforço desenvolvido nesse campo, surgiram as notas explicativas que são informações complementares às demonstrações 
contábeis, representando parte integrante das mesmas. (FIPECAFI, 2000, p.363)

As notas explicativas, elaboradas com rigidez técnica, não realizam as mediações adequadas aos conteúdos "legalmente" apresentados nos veículos de publicação. Uma prova disso é o crescimento de serviços de mediação institucional promovidos pelas companhias abertas, concomitantemente à evidenciação tradicional.

A Contabilidade tem uma função comunicativa. Como linguagem de especialidade, a Contabilidade tem como um de seus objetivos o ato de informar. Para tanto, gera novos produtos documentais, padroniza relatórios, desenvolve estratégias e pesquisas acadêmicas em torno da melhoria do conteúdo informacional.

O primeiro dos objetivos do órgão internacional de padronização de documentos contábeis - International Accounting Standards Board (IASB) -, melhor apresentado na seção 2, é o seguinte:

(a) desenvolver, no interesse público, um único conjunto de normas contábeis globais de alta qualidade, inteligíveis e exeqüiveis, que exigem informações de alta qualidade, transparentes e comparáveis nas demonstrações contábeis e em outros relatórios financeiros, para ajudar os participantes dos mercados de capital e outros usuários em todo o mundo a tomar decisões econômicas;

Em entrevista à revista Exame de 26 de novembro de 2003, Arthur Levitt, presidente da Security Exchange Commission (SEC) dos Estados Unidos de 1993 a 2001, fez recomendações às empresas brasileiras a respeito da necessidade de transparência nas informações, afirmando:

... é preciso que as empresas liberem informações importantes simultaneamente para todos os seus investidores, grandes $e$ pequenos. É necessário também que os relatórios produzidos pelas empresas, fundos mútuos, bancos de investimentos e também a CVM empreguem uma linguagem clara, evitando o jargão.

Porém, como melhorar a compreensão dos usuários na transferência de informações contábil-financeiras das companhias abertas? 
Os problemas já enumerados exigem abordagens que analisem criticamente as mediações praticadas e apresentem soluções para esses problemas. Muitos são os aspectos que poderiam ser investigados. Na presente pesquisa, definem-se como objetivos:

1. Relacionar os serviços informacionais gerados pelas companhias abertas aos paradigmas de transferência de informações de domínios específicos, estabelecidos nas Teorias da Comunicação e Informação;

2. Apresentar e analisar as práticas de mediação institucional realizadas pelas empresas estudadas;

3. Apresentar alternativas que possam aprimorar os processos de comunicação da informação contábil para os investidores.

Os pressupostos da pesquisa identificados com base na literatura da área e de entrevistas exploratórias realizadas na Associação dos Analistas e Profissionais de Investimento do Mercado de Capitais (APIMEC) são:

- As demonstrações contábeis apresentadas são produzidas em linguagem especializada da área contábil, não podendo ser compreendida sem conhecimentos prévios da terminologia empregada;

- As companhias abertas publicam suas demonstrações contábeis em jornais e também as tornam disponíveis em seus websites, porém tais acessos não garantem a construção do significado pelos diferentes segmentos de usuários;

- A Contabilidade tem desenvolvido novas demonstrações para suprir os usuários com mais elementos para suas decisões, porém os usuários têm buscado mediação das informações existentes para incrementar a tomada de suas decisões.

Com base nos pressupostos e na questão proposta neste estudo de casos múltiplos, as hipóteses fundamentais formuladas são: 
1. A Contabilidade deve empregar o conceito de mediação, segundo a Ciência da Informação, para melhorar a sua função comunicativa;

2. Os serviços de mediação implementados pelas empresas estão relacionados a um aumento de valor para seus proprietários;

3. A tecnologia utilizada é determinante para estes serviços de mediação.

Dessa forma, a redação deste trabalho está organizada de forma que esta primeira seção apresente o fenômeno observado e sua investigação científica em torno da questão de pesquisa e os objetivos decorrentes.

A seção 2 traz o referencial teórico, primeiramente um apanhado cronológico da evolução histórica da Contabilidade, enfocando a forma de realizar a sua função comunicativa. Em seguida, uma breve cronologia da Ciência da Informação, enfatizando as teorias das áreas relacionadas ao objeto de estudo.

A seção 3 apresenta o conceito e as funções do trabalho em Relações com investidores.

Complementando os resumos que descrevem cada seção, a seção 4 faz a integração da Ciência da Informação e da Ciência Contábil, apresentando a pesquisa aplicada, os procedimentos de investigação adotados, a metodologia para as entrevistas, a forma de tratamento das respostas, os usuários selecionados (executivos de Relações com Investidores), suas atribuições e usos das informações contábeis.

A seção 5 trará as respostas obtidas nas entrevistas, a análise e interpretação dos dados e a crítica das hipóteses segundo a referência teórica selecionada. Ao final serão apresentadas as principais conclusões do projeto. 


\section{seção: 2. Referencial Teórico e Contexto institucional}

Um relatório contábil pode ser definido como "exposição resumida $e$ ordenada de dados colhidos pela contabilidade" (MARION, 2005, p.39). Ao abordarem a utilização dos relatórios contábeis pelos investidores (usuários externos à empresa), Iudícibus e Marion afirmam:

é através dos relatórios contábeis que se identifica a situação econômico-financeira da empresa; desta forma, o investidor tem às mãos os elementos necessários para decidir sobre as melhores alternativas de investimentos. Os relatórios evidenciam a capacidade da empresa em gerar lucros e outras informações. (IUDícIBUS e MARION, 2000, p. 42).

O uso desses relatórios, como instrumentos de comunicação, também se insere na vocação da Contabilidade:

A Contabilidade se caracteriza como Ciência da avaliação da empresa como um todo, adotando sistemas de informações específicos, mas cuja tendência é de sistema global de informação e de comunicação. o objetivo da Contabilidade seria o de fornecer informações úteis para a tomada de decisões econômicas, ou em outros termos, permitir aos estratos de usuários a possibilidade de avaliar a situação patrimonial financeira da entidade e, em sua dinâmica, as tendências futuras. (GUAGLIARDI, 1987, p. 20)

As pesquisas desenvolvidas sobre os processos de comunicação tendem, segundo Lasswell (1977, p. 105), a se concentrar nos seguintes itens:

- Quem? - representado pelo "comunicador", é o item estudado na análise de controle;

- Diz o quê? - é a mensagem propriamente dita, estudada como análise de conteúdo;

- Em que canal? - é o veículo da mensagem, estudado em análise de meios (media);

- Para quem? - é o público alvo, o receptor, estudado como análise de audiência;

- Com que efeito? - é o produto, o conjunto de resultados e impressões causadas, estudado em análise de efeitos. 
O produtor da informação contábil, para efeito desse estudo, é a companhia aberta. É ela quem detém os dados e toma as decisões, das quais derivam o conjunto das demonstrações contábeis.

Entretanto, devido ao impacto das informações que as companhias prestam e também das que deixam de divulgar, tanto a forma como o conteúdo da informação contábil têm sido objetos de pesquisas e regulamentações, notadamente desde o início do século XX.

As análises relativas ao controle da informação contábil e seu conteúdo partem da função social da contabilidade. Essa função é o fundamento da divulgação compulsória, que, no Brasil, ocorre na forma da Lei das Sociedades por Ações e nas regulamentações emitidas pela Comissão de Valores Mobiliários (CVM). Dentre os objetivos da CVM está a proteção do investidor contra o uso de informações não divulgadas igualmente para todos no mercado, além de evitar ou coibir tipos de fraudes destinadas a criar condições artificiais de demanda, oferta ou preço dos valores mobiliários. Para esta pesquisa, um objetivo da CVM merece destaque - o de assegurar o acesso por parte do público a informações sobre os valores mobiliários negociados e sobre as companhias que os tenham emitido.

Resumidamente, o aspecto social pode ser apresentado como:

...tentar fazer com que a informação financeira relevante se torne publicamente disponível tão depressa quanto factível para minimizar a possibilidade de uso de informação privilegiada. Quando a informação privilegiada é utilizada vantajosamente por alguns indivíduos, outros participantes saem perdendo. (HENDRIKSEN e VAN BREDA, 1999, p. 119)

Quanto à análise de meios, os principais veículos para as informações contábil-financeiras, além da publicação das demonstrações contábeis em jornais, são os websites das empresas na Internet, materiais impressos e informações gravadas em CDs. Sendo assim, as formas de acesso a este conjunto de informações podem ser analisadas por duas frentes:

a) A estrutura padronizada das demonstrações; 
b) Os produtos de mediação, assim chamadas as demais formas de contato explicativas orais, eletrônicas ou impressas entre as companhias abertas e os investidores.

Entretanto, grande parte das formas de divulgação voluntária de informações - ou seja, além das legalmente exigidas - que predomina em contabilidade derivam de pesquisas e regulamentações oriundas de países com forte tradição em mercados de ações. No Brasil, a tendência decorre do modelo de divulgação internacional, que é regido pelo seguinte objetivo: "dar informações sobre a posição financeira, os resultados e as mudanças na posição financeira de uma entidade, que sejam úteis a um grande número de usuários em suas tomadas de decisão" (IASB, 2001 p. 46).

Quanto ao público-alvo, os investidores constituem o grupo de referência para a produção de informações, em parte por seu inerente direito de conhecer o patrimônio e os resultados da empresa, mas também porque "em parte, o motivo dessa falta de ênfase em outros usuários, que não investidores, é devida à ausência de conhecimento a respeito de suas decisões." (HENDRIKSEN e VAN BREDA, 1999, p. 511).

Quanto ao efeito, concluindo o resumo de Lasswell supracitado, uma análise de efeito da comunicação contábil é parte da discussão pretendida na pesquisa, na forma de estudo da mediação praticada pelos setores de "Relações com Investidores" das empresas selecionadas. Afinal, o ato de comunicação pressupõe a geração de um efeito para quem se destina e para quem se pretende influenciar, conforme Berlo:

Nosso objetivo básico na comunicação é nos tornar agentes influentes, é influenciar outros, nosso ambiente físico e nós próprios, é nos tornar agentes determinantes, é termos opção no andamento das coisas. Em suma, nós nos comunicamos para influenciar - para influenciar com intenção. (BERLO, 1999, p.12)

Acredita-se que as informações contábeis divulgadas têm uma forte influência nas decisões econômicas de investidores, entre outros usuários, e que estão associadas às perspectivas que se formam em torno do futuro da empresa. É cada vez menor o número de empresas que processam informações contábeis ainda 
com a seguinte mentalidade: "É comuníssimo escritores pensarem que o seu trabalho seja escrever relatórios técnicos, em lugar de influenciar o comportamento dos leitores" (BERLO, 1999, p. 13).

Permitir ao leitor inferir sobre os fluxos futuros de caixa, perceber o grau de acuidade com que os valores foram levantados e em qual tempo de realização são atributos dos relatórios contábeis, dentre os quais se destacam o conjunto de demonstrações contábeis e as notas explicativas (complementares às demonstrações).

No website da Comissão de Valores Mobiliários - órgão regulador do Mercado de Valores Mobiliários no Brasil, há um "rol de notas explicativas" sugerido, com a seguinte apresentação:

Dessa forma, dando continuidade a essa política, qual seja, concorrer para a melhoria das informações divulgadas pelas companhias abertas, apresenta-se uma consolidação de notas explicativas, que resultou do trabalho de pesquisa em Instruções, Deliberações e Pareceres de Orientação da CVM, além de Ofícios-Circulares da Superintendência de Normas Contábeis e de Auditoria da autarquia. Sempre que necessário, as devidas atualizações serão procedidas.

Como se observa, os relatórios contábeis são uma composição documental, regulada pelos órgãos oficiais, obrigatória para as companhias abertas e emitida em linguagem técnica. O papel do órgão regulador é "concorrer para a melhoria das informações divulgadas pelas companhias abertas", isto é, para auxiliar o usuário a tomar decisões econômicas. Em torno dessa função, diversos relatórios são criados ou remodelados, os processamentos dos dados são acelerados, surgem novas terminologias etc., conforme definido abaixo:

A Contabilidade é o grande instrumento que auxilia a administração a tomar decisões. Na verdade, ela coleta todos os dados econômicos, mensurando-os em forma de relatórios ou de comunicados, que contribuem sobremaneira para a tomada de decisões. $A$ Contabilidade é a linguagem dos negócios. Mede os resultados das empresas, avalia o desempenho dos negócios, dado diretrizes para tomadas de decisões. (MARION, 2005, p. 23) 
A Contabilidade analisa as decisões econômicas possíveis e busca fornecer as informações necessárias para dar suporte às mesmas. Com este objetivo, os sistemas de informação contábil, nas empresas, evoluem juntamente com os avanços alcançados nas melhorias dos processos e da técnica.

De maneira geral, pode-se dizer que um sistema de informação contábil será tão avançado quanto mais for capaz de produzir todos os relatórios gerenciais (além dos tradicionais) da forma mais automática e repetitiva possível, com o menor grau de trabalho adicional por parte do contador. (IUDÍCIBUS e MARION, 2000, p. 55)

Nesta citação, o avanço no sistema de informação contábil está associado a processos automatizados e controlados pelo contador, que é o elaborador do relatório. Isso reflete um método centralizado no emissor da informação.

\subsection{A Linguagem Contábil}

Registros de negócios, inventários de patrimônio e de comércio de trocas são encontrados em diversas civilizações há mais de 8.000 anos AC, tais como China, Egito, Caldéia, Pérsia, entre outras, conforme D'áuria (1959). Porém, os primeiros registros de técnicas contábeis similares aos que deram singularidade à linguagem contábil remontam ao século XII. Embora não haja menção a um ou mais criadores dessa especialidade, o registro mais antigo de uma escrituração contábil foi encontrado no acervo municipal da cidade de Gênova, Itália, relativo ao ano de 1.340, segundo Hendriksen e Van Breda (1999).

A História da Contabilidade teve um marco após a invenção da prensa por Gutemberg em 1440: foi o trabalho de seu primeiro codificador, um religioso italiano e professor de matemática de nome Lucca Pacioli. Sua obra intitulou-se "Summa de arithmetica, geometrica, proportioni et proportionalitá" e foi publicada, em Veneza, em 1.494, segundo D'áuria (1959). Grande parte dos termos do vocabulário técnico da contabilidade data dessa mesma época, conforme observa o historiador contábil 
Littleton, na citação de Hendriksen (Op.cit. p. 40), "fica-se impressionado (...) com o pouco que acrescentamos à contabilidade nos anos que se passaram desde então".

A característica mais peculiar da linguagem contábil é o método das "partidas dobradas", o que significa que, para cada evento econômico registrado, a origem e a aplicação dos recursos envolvidos são identificadas equanimente. Esta é a base nocional da Contabilidade como linguagem de especialidade, se considerarmos que:

A todo e qualquer campo de conhecimento corresponde um conjunto de noções que lhe é próprio. As áreas especializadas da experiência humana devem ter seu universo nocional devidamente identificado a partir de um dado ponto de vista, para que seja possível organizá-lo de forma sistemática, ou seja, inter-relacionada. (CINTRA et al, 2002, p.49)

Ou seja, sem esta forma de documentação padronizada e a terminologia de "débito" e "crédito", à Contabilidade faltaria o elemento de identidade, pois:

\begin{abstract}
A ausência de um sistema de noções devidamente sistematizado inviabiliza o empreendimento de dar forma a um conjunto de palavras, na medida em que esbarra, necessariamente, em dificuldades advindas da falta de compreensão ou da compreensão incorreta das possibilidades de relacionamento entre termos. (CINTRA et al, 2002, p. 49)
\end{abstract}

As principais alterações experimentadas pela contabilidade no passar dos séculos podem ser observadas sob um único estímulo: as novas formas de se prestar contas ao proprietário. Essa análise é possível com base em algumas práticas da contabilidade da época, assim descritas:

1. Durante o período que se estende até o século XVI, o principal objetivo da contabilidade era produzir informação para o proprietário - geralmente proprietário único. Em conseqüência, as contas eram mantidas em sigilo e não havia pressão externa, como hoje, no sentido de exatidão ou da adoção de padrões uniformes de divulgação.

2. Em parte, em decorrência da primeira observação, geralmente não era feita distinção clara entre os negócios pessoais e empresariais de um proprietário (...)

3. Os conceitos de exercício contábil e empresa em funcionamento inexistiam. Muitos empreendimentos eram de curta duração, ou continuavam apenas após a realização de algum objetivo empresarial 
específico. Em conseqüência, o lucro só era calculado quando da conclusão do empreendimento. (HENDRIKSEN e VAN BREDA, 1999, p.40).

Outro momento histórico que promoveu grandes avanços na contabilidade foi a Revolução Industrial. Muitas manufaturas eram constituídas por associações de empresários, permitindo a diversificação de investimentos, agora não mais vinculados somente às companhias de navegação.

Também se atribui às novas formas de investimentos, trazidas pela Revolução Industrial, a especialização profissional em contabilidade, seguida pelas primeiras associações de contadores.

A grande depressão resultante da queda bruta de investimentos na Bolsa de Nova York, em 1929, fortaleceu a preocupação com a padronização de procedimentos de contabilização, de forma a possibilitar comparações e verificações dos resultados apresentados pelas empresas. "Muitos indivíduos e grupos começaram a trabalhar na elucidação do que acreditavam ser princípios contábeis na década de 30." (HENDRIKSEN e VAN BREDA, 1999, p. 74).

\subsubsection{O Desenvolvimento contábil após a $2^{\mathrm{a}}$ Guerra Mundial}

No período de 1925 a 1950, nos Estados Unidos, o governo se interessou pelos sistemas orçamentários desenvolvidos pela Contabilidade nas empresas, sendo que a ONU adotou um sistema de orçamento público nesta base, conforme Pereira et al (2005). Nesta época começam a ser cunhados os relatórios especializados, como os financeiros, os tributários e os controles de custos e investimentos.

Entre 1950 e 1975, a intensificação do processamento de dados, permitida pelo uso de computadores, trouxe um impulso ao desenvolvimento do conhecimento contábil e deu origem aos novos modelos de gestão, conforme Pereira et al (2005).

Ainda nos Estados Unidos, sucederam-se boletins e pareceres de associações de profissionais e pesquisadores em contabilidade na busca por uma base teórica unificada para a matéria, dentre os quais se destacou um documento produzido pela American Association of Accountants (AAA), intitulado "A Statement 
of Basic Accounting Theory" em 1966 e o pronunciamento n. 4 do American Institute of Certified Public Accountants (AICPA), denominado "Basic Concepts and Accounting Principles Underlying Financial Statements of Business Enterprises". Dentre estas pesquisas, destacou-se a busca por um "referencial conceitual", sendo que o principal deles foi emitido pelo Financial Accounting Standards Board (FASB), por meio da publicação de seis documentos, em um período compreendido entre 1978 e 1985.

\begin{abstract}
A divulgação financeira deve fornecer informações que sejam úteis para investidores e credores atuais e em potencial, bem como para outros usuários que visem a tomada racional de decisões de investimento, crédito e outras semelhantes. As informações devem ser compreensíveis aos que possuem uma noção razoável dos negócios e das atividades econômicas e estejam dispostos a estudar as informações com diligência razoável. (HENDRIKSEN e VAN BREDA, 1999 p. 93, sintetizando SFAC 1)
\end{abstract}

Em 1973, por meio de um acordo feito entre órgãos da profissão contábil da Austrália, Canadá, França, Alemanha, Japão, México, Holanda, Reino Unido, Irlanda e Estados Unidos, foi criado o International Accounting Standards Committee (IASC). A este Comitê foram acrescentadas, de 1983 a 2001, todas as entidades profissionais de Ciências Contábeis que já faziam parte da Federação Internacional de Contadores, o IFAC. Esta medida viabilizou a inclusão de novos países. As atividades do IASC são conduzidas pelo órgão International Accounting Standards Board (IASB) - com os seguintes objetivos, consolidados em uma Constituição:

(a) desenvolver, no interesse público, um único conjunto de normas contábeis globais de alta qualidade, inteligíveis e exeqüiveis, que exigem informações de alta qualidade, transparentes e comparáveis nas demonstrações contábeis e em outros relatórios financeiros, para ajudar os participantes dos mercados de capital e outros usuários em todo o mundo a tomar decisões econômicas;

(b) promover o uso e a aplicação rigorosa dessas normas; e

(c) promover a convergência entre as normas contábeis locais e as Normas Internacionais de Contabilidade para soluções de alta qualidade.

(IASB - 2001, p.11) 
Estes objetivos convergem para o enfoque maior da comunicação contábil: o auxílio à tomada de decisões econômicas.

\subsubsection{A Contabilidade como uma linguagem especializada}

As décadas seguintes da Contabilidade foram marcadas pela proliferação de novos relatórios, diversificação da manipulação dos dados, geração e aceleração de processos informacionais, com o uso de tecnologia cada vez mais sofisticada e a intersecção de conceitos da Administração e Economia.

É possível observar o desenvolvimento das Ciências Contábeis por meio da geração de novas demonstrações, que constituem documentos para a apresentação do objeto essencial de estudo: o patrimônio de uma entidade.

A grande maioria das demonstrações contábeis, que atingem a aceitação necessária para gerar sua adoção pelas empresas e seu ensino nas Universidades, é criada por professores universitários e/ou profissionais de alto nível técnico. Isso cria alguns traços comuns aos novos documentos: utilização da terminologia contábil, criação de novos termos e nível elevado de conhecimento da especialidade.

Como pesquisa anterior a este estudo e que lhe serve de fundamento, está a tese de doutorado apresentada à Faculdade de Economia, Administração e Contabilidade da Universidade de São Paulo, intitulada "A evidenciação de informações em companhias abertas - um estudo exploratório", de José R. Guagliardi. Este autor define que:

O objetivo da Contabilidade seria o de fornecer informações úteis para a tomada de decisões econômicas, ou em outros termos, permitir aos estratos de usuários a possibilidade de avaliar a situação patrimonial financeira da entidade e, em sua dinâmica, as tendências futuras." (GUAGLIARDI, 1987, p. 20).

Seu trabalho gerou um novo modelo de publicações, pois, em sua visão:

A contabilidade é ciência essencialmente utilitária a qual reage através de mecanismos intrínsecos aos estímulos gerados pelas expectativas de informações dos diversos setores da economia. (...) Muitos procedimentos contábeis foram estabelecidos sem um embasamento teórico e sim pelo pragmatismo contábil ao selecionar 
conceitos e técnicas contábeis, considerando significativamente a sua utilidade para atender objetivos específicos de alguns estratos de usuários de informação contábil. (GUAGLIARDI, 1987, p. 33)

Como usuários, o mesmo autor apresentou:

Por suas características intrínsecas, podemos classificar os estratos de usuários da informação:

a) Entidades Governamentais: disciplinadores legais, subsidiadores de desenvolvimento, grandes compradores; interessados em receita e lucros tributáveis, produtividade, valores adicionados, mão de obra empregada, benefícios à comunidade etc.

b) Financiadores: fornecedores de recursos ao desenvolvimento dos empreendimentos, com direito de regresso; interessados em conhecer fluxos futuros de caixa, capacidade e reputação da administração, perspectivas futuras.

c) Administração: controladores e disseminadoras de práticas para boa manutenção de taxas de retorno razoáveis e administração adequada do endividamento.

d) Empregados e sindicatos: disciplinadores de recursos humanos. Interessados na continuidade da empresa e na capacidade de manutenção e desenvolvimento de benefícios.

d) Entidades sociais: fiscalizadores das preservações sociais e ecológicas. Interessados nos planos de benefícios e de proteção ao meio ambiente.

f) Fornecedores e clientes: supridores de bens e de serviços; compradores de bens ou serviços. Interessados na continuidade da empresa e sua capacidade de saldar e fornecer benefícios passados, presentes e futuros.

g) Acionista majoritário: administração ou contratante da administração. Determina os destinos da empresa, sujeito a pressões de outros estratos de usuários. Interessado no desenvolvimento dos negócios, manutenção do lucro por ação, do fluxo de dividendos e da posição no mercado de ações.

h) Acionistas minoritários e investidores: aplicadores em ações sem condição de influírem na administração (destinos dos negócios). Interessados na performance da empresa capaz de manter fluxo de dividendo, lucro por ação, preço de cotação no mercado de ações.

i) Agentes do mercado de ações investidores ou intermediários: fornecedores das condições de expansão da capitalização e da liquidez das ações no mercado. Interessados no desempenho e perspectivas da empresa a fim de assessorar os investidores e/ou manutenção de carteiras de títulos, administração de clubes e fundos de investimentos em ações.

Pode-se considerar na acepção exata do termo, o segmento mais frágil de usuário de informação, aquele que dificilmente influenciaria na administração da empresa. (...)

j) Outros usuários: público em geral, órgãos nacionais e internacionais para padronização de informações, acordos comerciais e tecnológicos, ajuda econômica e social. Distantes ou próximos de modificarem atitudes de administração. Interesses são os mais variados possíveis. (GUAGLIARDI, 1987, p. 37) 
Sua pesquisa empírica foi aplicada ao segmento "i", agentes do mercado de ações investidores ou intermediários - especificamente, as corretoras com operação na BOVESPA. Além de traçar o perfil dessa modalidade de usuários supracitada, a tese ainda apresenta um novo modelo para uma demonstração contábil que pudesse ser mais útil para este usuário. Os principais resultados de sua pesquisa estão resumidos nos anexos.

Assim como essa tese, foram criados novos relatórios contábeis, procedimentos e processamentos da informação, notadamente a partir da década de 80, tais como: o sistema de tratamento de custos de produção e de gerenciamento baseado na divisão por atividades (Activity Based Costing e Activity Based Management); o Balanced Scorecard, dos acadêmicos Kaplan e Norton; a incorporação da estratégia empresarial na contabilidade, na obra dos mesmos autores intitulada The Strategy-focused Organization; o conceito de valor adicionado surgido da França - valeur ajouté - segundo Queiroz (1988), o qual se refere à Demonstração do Valor Adicionado (DVA); o controle de qualidade na contabilidade Kanatsu (1990); a contabilidade acelerada e pontual de Bragg (Just-in-time accounting, 1996) e assim sucessivamente.

Estas produções fazem surgir duas inferências fundamentais para esta pesquisa:

a) a visão de que a Contabilidade pode ser definida e pesquisada como uma linguagem. Dentre as linguagens de especialidade, esta pode ser considerada, conforme o senso comum, "a linguagem dos negócios".

b) é o criador do novo produto informacional que determina o objetivo deste, para quem se destina e para quais aplicações. Dito de outro modo, embora direcionado ao usuário, a apresentação do novo produto informacional reflete o que o emissor elege como importante e para qual decisão econômica se adequa. 


\subsection{Conceitos de Ciência da Informação relacionados ao}

\section{tema}

Um problema de comunicação institucional relacionado à interface entre empresa e usuários, que perfila a linguagem de especialidade contábil, gerou esta pesquisa possibilitando a discussão interdisciplinar entre as Ciências da Informação e a Contábil.

\subsubsection{Cronologia recente da Ciência da Informação}

Conforme Ferneda (2003), a primeira formulação do que veio a ser chamado de Ciência da Informação resultou das conferências do Georgia Institute of Technology de 1961 e 1962, onde foi definido como Ciência da Informação:

a ciência que investiga as propriedades e comportamentos da informação, as forças que regem o fluxo da informação e os meios de processamento da informação para uma acessibilidade e usabilidade ótimas. Os processos incluem a origem, disseminação, coleta, organização, recuperação, interpretação e uso da informação. O campo deriva de ou relaciona-se com a matemática, a lógica, a lingüística, a psicologia, a tecnologia da computação, a pesquisa operacional, as artes gráficas, as comunicações, a biblioteconomia, a administração e alguns outros campos. (SHERA e CLEVELAND, 1977, apud FERNEDA, 2003, p. 6)

A consolidação da Ciência da Informação é um processo de construção relativamente recente em torno de seu objeto, o qual pode ser definido como: a promoção da comunicação da informação desejada entre seu produtor e o destinatário de forma eficaz.

Dentre as definições mais citadas nos trabalhos científicos, encontra-se a de Borko: 
Ciência interdisciplinar que estuda as propriedades $e \quad o$ comportamento da informação e as técnicas, tanto manuais quanto mecânicas de processar a informação visando sua armazenagem, recuperação e disseminação. (BORKO, 1968, p. 3)

Na década de 90, Saracevic propõe uma definição para a Ciência da Informação, que se torna paradigmática:

A Ciência da Informação é um campo dedicado às questões científicas e à prática profissional voltadas para os problemas da efetiva comunicação do conhecimento e de seus registros entre os seres humanos, no contexto social, institucional ou individual do uso e das necessidades de informação. No tratamento destas questões são consideradas de particular interesse as vantagens das modernas tecnologias inforrmacionais. (SERACEVIC, 1996, p.47)

Para esta pesquisa, é interessante citar alguns movimentos que ocorreram a partir da década de 70. Nesta época, prevaleceu, nos trabalhos em Ciência da Informação, o enfoque na sucessão de técnicas de melhorias nos processos documentários, com ênfase no aprimoramento da documentação em si. Essa é a chamada abordagem tradicional - a que privilegia o documento, sem muita preocupação em relacioná-lo com o usuário, conforme Ingwersen (1992).

Subseqüentemente, surgem estudos que criticam o excessivo enfoque na evolução técnica e apresentem o usuário como a principal ênfase. É o início do período onde despontou a abordagem centrada no usuário, que demonstrou as seguintes características, segundo Ingwersen (1992):

- Objetivo e enfoque: estudo da representação dos problemas de informação, comportamento de pesquisa e os componentes humanos dos sistemas de informação em situações reais. A ênfase está no usuário individual e a representação da informação que ele busca diante do agente intermediário (bibliotecário), visando desenvolver a eficácia da recuperação da informação;

- Tipos de resultados e conseqüências: a recuperação da informação é vista como solução de problemas e orientação de objetivo em processo 
interativo. Diversos tipos de usuários freqüentemente com perguntas mal definidas e ambíguas;

- Compreensão da informação: informação em contexto amplo resumos (abridged), materiais não científicos, informações culturais e emocionais. A recuperação da informação desempenha papel importante na transferência de informação e comunicação em todos os níveis da sociedade;

- Utilização de Disciplinas de apoio: ciências cognitivas, psicologia, psicolingüística e inteligência artificial.

As pesquisas na Ciência da Informação percorreram os componentes do processo comunicativo, dito de outro modo, passaram pelo emissor, pelo documento, pelo veículo e pelo receptor, não nesta ordem necessariamente. Ainda assim, esta disciplina lida com o fenômeno da comunicação, não se limitando a um ou outro processo comunicativo, nem a meios de registro e documentação. Nessa visão, em 1978, Belkin (Belkin p. 58, apud Ingwersen) identifica cinco áreas relacionadas a essa ciência:

a)Transferência de informação em sistemas de comunicação humana - formal e informal -, ou seja, o fluxo entre instituições;

b)a noção de informação desejada - compreensão da geração e desenvolvimento de necessidades de informação na sociedade, entre grupos específicos ou indivíduos;

c)a eficácia dos sistemas de informação e transferência de informação - métodos e tecnologias que promovem o desempenho e qualidade da informação e dos sistemas de informação. Lida, portanto, com o desenvolvimento de teorias e modos para facilitar os processos de informação entre produtores e usuários;

d)as relações entre informação e produtor - conhecimento produzido e as formas de analisá-lo e representá-lo em sistemas de informação textuais;

e)a relação entre informação e usuário - estudo da relevância e o valor da informação.

Para o mesmo autor, a atual noção de "informação desejada" significa a junção dos estudos de cada participante da comunicação. Contém o estudo dos 
usuários, seus desejos e motivações para a busca da informação armazenada por diversos tipos de sistemas, os processos de acessar tal informação, seu uso e a obtenção de sentido. A Ciência da Informação comporta diversos tipos de usuários e permeia praticamente todas as áreas.

Finalizando esta sucinta retrospectiva, nos estudos sobre informação despontaram a esfera da cognição (Belkin, 1984), da linguagem e da produção de sentido (Blair, 1992), assim como das comunidades e suas práticas sociais (Capurro, 1991).

A transição de ênfases fez parte da busca do processo comunicativo como algo a ser estudado no todo. A estrutura e função da comunicação envolvem o emissor, a mensagem, o meio e o receptor, como componentes de um mesmo processo. A Ciência da Informação concentra os estudos sobre este processo interrelacionado dos componentes do ato da comunicação e sua teoria ganha corpo nas aplicações em outros campos do saber.

À medida que na academia a 'recém-nascida' Ciência da Informação está se reabilitando na ordem simbólica do saber científico, a exigência de teorização passou a ser cada vez mais central e, neste contexto, destaca-se a representação, notadamente na área do tratamento da informação. (PINTO, 2002, p. 117)

É possível analisar como a consolidação da teoria constitutiva da Ciência da Informação também evoluiu em diversos domínios, assumindo e assimilando características práticas.

\subsubsection{Informação e mediação}

Para este estudo, foi selecionado um aspecto específico da informação institucional - sua mediação, que compreende a recepção e a criação de significado:

A informação ganha sua existência tão-somente no plano de quem a recebe e não no plano de quem a emite. Na origem, tem-se apenas um conjunto de dados, que se pretende mais que meras cifras, mas que ainda não são informações. Assim, o dado só se tornará informação na medida em que provoque alguma ação por parte de 
quem o recebe, vale dizer, quando altera alguma estrutura vigente, $o$ que nem sempre ocorre. Resulta que a informação é da ordem da subjetividade, enquanto o dado é da ordem da objetividade. (SENRA, 1994, p. 38).

As modernas tecnologias e as divulgações financeiras on-line têm facilitado às empresas prestar esclarecimentos aos usuários. Para Polistchuk e Trinta:

Uma marca definitiva da contemporaneidade pode assim ser dada pela criação de máquinas, dispositivos técnicos e mecanismos comunicacionais que possibilitam a generalização dos processos de mediação. (POLISTCHUK e TRINTA, 2003, p. 146)

A mediação, para esta pesquisa, é entendida como a criação ou construção de significado. Isso ocorre quando há interferência explicativa entre o emissor e o receptor da informação.

Mediar significa fixar entre duas partes um ponto de referência comum, mas eqüidistante, que a uma e a outra faculte 0 estabelecimento de algum tipo de inter-relação. Mediações são estratégias de Comunicação. Pelas mediações de que participa, o ser humano representa a si próprio e aquilo que se passa em seu entorno, fazendo com que ocorra uma positiva produção de sentidos, a serem propostos e transacionados, e, finalmente, partilhados. (POLISTCHUK e TRINTA, 2003, p. 148).

A mediação também pode ser vista como o resultado de explicações e esclarecimentos oferecidos ao usuário, sendo, neste estudo, o serviço de comunicação de informações contábil-financeiras das companhias abertas.

O que se deve diferenciar é o caráter da comunicação e o da informação. Enquanto esta se apresenta dentro de uma moldura que se propõe alterar a estrutura cognitiva do receptor, aquela opera com os efeitos de sentido que irá provocar no receptor, sem que necessariamente ofusque a informação propriamente dita e que dela se possa dispensar. (TAVARES, 2002, p. 140)

As formas de comunicação empresarial estão relacionadas a "efeitos de sentido no receptor", enquanto que a informação está relacionada à "estrutura cognitiva", daí a importância da mediação. 
A origem do estudo da mediação está relacionada às pesquisas que visavam à compreensão dos processos de recepção, particularmente a televisiva. Segundo Fujino, a recepção começa a ser estudada como:

um processo no qual o receptor tem um papel ativo em um ambiente com características peculiares que o influenciam na apropriação das mensagens. (...) os estudos sobre o tema permitem uma melhor compreensão sobre o processo de produção da ressignificação, de apropriação ou incorporação das mensagens pelos sujeitos receptores, em um determinado espaço sociocultural. (FUJINO, 2000, p.68).

A mesma autora apresenta, em sua tese, duas abordagens sobre o estudo das mediações na América Latina, cujos autores são Martin-Barbero e Orozco Gómez. Para este último,

existem diversas mediações: a cognitiva, a cultural, as de referência, as institucionais e as originárias do meio de comunicação, onde a mediação considerada fundamental é a cultural. A cultura é que determina o desenvolvimento específico das habilidades cognitivas particulares (como a capacidade analítica, dedutiva, indutiva, etc), ao privilegiar o exercício de uma sobre a(s) outra(s). Tais abordagens centralizam as preocupações no receptor e não necessariamente no produtor da mensagem, embora considerem a necessidade de estudar a recepção no contexto da produção. (GOMEZ, apud FUJINO 2000, p. 70)

Ao enfocar a mediação da informação contábil, esta pesquisa se limita à mediação institucional, ou seja, uma das formas de criação de significado utilizada pelas empresas, em particular, as Companhias Abertas. Este serviço está a cargo das denominadas áreas de relações com investidores, que agregam profissionais com a função de criar atendimentos e produtos de comunicação e de mediação.

Para o modelo teórico-recepcional, "são as mediações - e não tanto as ações da mídia - que explicam e justificam o processo de recepção" (POLISTCHUK e TRINTA, 2003, p. 150). Embora a produção de sentido seja esperada na comunicação, tal sentido não se concentra na codificação do emissor, nem no meio escolhido para a divulgação, nem no processo que o receptor utiliza para decodificar. 
O sentido de uma mensagem repousará na interação continuada desses fatores, a cada um cabendo parcela de igual importância para que se consume, pela proposição de um sentido, a comunicação pretendida. (POLISTCHUK e TRINTA, 2003, p. 151)

Aplicado ao objeto desta pesquisa, não é somente pelo aperfeiçoamento dos relatórios contábeis e pela melhoria nos critérios técnicos de valoração do patrimônio e dos eventos que a Contabilidade registra que haverá progresso na percepção do destinatário da mensagem.

A comunicação contábil tem uma forte orientação para o uso de tecnologias de informação para tratar de indicadores acumulativos e para aumentar a velocidade dos processamentos. Porém, o desenvolvimento das funções de uso corre muito à frente do conhecimento sobre o usuário. Dito de outro modo, assim como ocorreu na Ciência da Informação, também na evolução da comunicação contábil observa-se a busca de melhoria de processos precedendo a busca das necessidades dos usuários.

Segundo Guerreiro,

A abordagem da teoria da comunicação da contabilidade considera o reconhecimento dos tipos de informação necessária para cada tipo principal de usuário. A nível prático essa premissa não se materializa, e em nível de teoria não temos observado contribuições significativas nesse sentido. (GUERREIRO, 1989, p. 21)

Esta citação corrobora um dos pressupostos para a pesquisa enumerados neste projeto, os quais foram coletados em entrevistas exploratórias. A idéia da falta de "materialização" da necessidade do usuário se exemplifica no seguinte pressuposto: as companhias abertas publicam suas demonstrações contábeis em jornais e também as tornam disponíveis em seus websites, porém tais acessos não garantem a construção do significado pelos diferentes segmentos de usuários. Este é um dos casos referidos por Barbosa (1997, p. 2) "Atualmente se reconhece que, em alguns casos, mais informação não resulta necessariamente em menos incerteza."

Entretanto, nota-se que os avanços tecnológicos trazem também vastas possibilidades de desenvolvimento da comunicação interativa com os usuários. 
Uma marca definitiva da contemporaneidade pode assim ser dada pela criação de máquinas, dispositivos técnicos e mecanismos comunicacionais que possibilitam a generalização dos processos de mediação. (POLISTCHUK e TRINTA, 2003, p. 146)

Esta vertente tecnológica é, na sociedade contemporânea, o veículo, por excelência, de aproximação entre produtos informacionais contábeis, emitidos pelas empresas, e usuários. Há uma diferença fundamental, estudada neste trabalho, entre os serviços informacionais desenvolvidos na pesquisa contábil mais recente e os desenvolvidos pelas companhias abertas. As empresas investem no conhecimento e na interatividade com seu receptor, buscando gerar nele o significado que ela deseja ter embutido na emissão, de forma muito mais agressiva que as pesquisas na área contábil. Estas investem, conforme já dito, no desenvolvimento documentário prioritariamente.

Porém, a Ciência da Informação, tal como as Ciências da Comunicação, assume que o sentido é processo gerado na mente do próprio receptor:

Um receptor costuma 'reconhecer mensagens', no sentido de que as submete, para fins de interpretação, ao crivo referente aos valores sociais que defenda, ao grau de instrução escolar que possua, à experiência de vida que tenha e à lógica de raciocínio que habitualmente adote. Pelo recurso ao código, que em algum grau de domínio tem em comum com o emissor, ele decodifica a mensagem; pelo exercício de seu repertório, ele a reconhece. Pela negociação mediadora, ele a dota de sentido. (POLISTCHUK e TRINTA, 2003, p. 150)

É necessária a utilização de métodos e técnicas para se aproximar do resultado esperado, útil e significativo para o usuário. Ou seja, conforme o texto a seguir, a produção do conhecimento não se faz por mero acesso à informação contábil.

Agente mediador da produção de conhecimento, o conceito de assimilação da informação é um processo de interação entre 0 indivíduo e uma determinada estrutura de informação, que gera uma modificação em seu estado cognitivo, produzindo conhecimento, que se relaciona corretamente com a informação recebida. É um estágio qualitativamente superior ao acesso e uso da informação. (BARRETO, 2002, p. 49) 
Portanto, a assimilação da informação não é conseqüência inerente ao processo da divulgação ou de tornar esta informação disponível e acessível. A mediação da informação contábil é a interface que promove o entendimento do usuário.

\subsubsection{O ciclo documentário na Contabilidade}

A Contabilidade, nas empresas, registra, processa e organiza informações das diversas áreas, as quais compõem o sistema organizacional, entre outras funções. Produz documentos, intitulados como relatórios contábeis, que tem o objetivo de informar tematicamente o patrimônio, a rentabilidade, o fluxo de recursos entre outros itens. Esta produção de relatórios, a partir de valores numéricos e conceitos econômicos, tem proximidade com os processos de análise documentária, pois:

Enquanto parte constitutiva de uma área de conhecimentos, a Análise Documentária assimila, necessariamente, os objetivos globais do tronco do qual é membro, qual seja o de determinar e criar princípios e mecanismos que promovam a circulação de informações e de documentos. (KOBASHI, 1994, p. 15)

Por força da legislação societária e tributária, o ciclo da elaboração destes documentos apresenta periodicidade mínima determinada, de onde se origina a "data de fechamento". Esta expressão marca o fim dos novos registros para que se possa incluir todo o arquivo disponível na constituição das demonstrações contábeis e para os cálculos dos impostos. Particularmente, as citadas demonstrações contábeis integram a função comunicativa da Contabilidade, pois representam, para as companhias abertas, o conjunto documentário a ser divulgado na mídia. É a informação contábil que circula no mercado, guardando relação com a Ciência da Informação, pois: 
A circulação de informações e documentos, tal como é compreendida no âmbito da Ciência da Informação, comporta as seguintes operações básicas: a) coleta de documentos; b) tratamento de documentos e c) difusão dos documentos. (KOBASHI, 1994, p. 15)

Mesmo dentro de uma formatação legal, existe a preocupação com o sentido do que é informado, conforme anuncia o mais novo princípio da Contabilidade:

\begin{abstract}
A fim de que a informação contábil represente fielmente a transação $e$ outros eventos que ela tem a finalidade de representar, é necessário que os eventos sejam contabilizados e as informações sejam apresentadas de acordo com sua substância e realidade econômica e não meramente com sua forma legal. (IUDíCIBUS e MARION, 2000, p. 115)
\end{abstract}

Assim, buscando representar os eventos econômicos contínuos, cuja sucessão produz a prosperidade ou o recuo de riqueza nas empresas, "os relatórios contábeis significam os produtos finais da Contabilidade" (IUDíCIBUS e MARION, 2000, p. 183).

\title{
2.2.4 Características da informação contábil
}

Como cenário gerador da necessidade de uma estrutura de conceitos e de terminologia específica, podem ser citadas as necessidades de informação advindas das movimentações do capital pelos mercados. Dentre estas, destacam-se a diversificação de investimentos, significando que um mesmo controlador de recursos financeiros aplica seu capital em empresas de setores e atividades diferentes. Isso, entre outras razões, gera a necessidade de comparabilidade de demonstrações contábeis, ou seja, permitir que tais investimentos possam ser avaliados a partir de uma mesma linguagem de especialidade. Outra forma de movimentação de capitais se dá pela globalização dos mercados, vista como o interesse em participar de empresas em diferentes países e moedas. Sobressai aqui a necessidade de 
informações padronizadas, que se refiram aos mesmos conceitos, em vários idiomas, com a mesma profundidade e transparência.

As Normas Internacionais de Contabilidade, editadas pelo International Accounting Standards Board (IASB), dedicam um capítulo à estrutura conceitual da Contabilidade. Nesse capítulo estão as características qualitativas das demonstrações contábeis, transcritas a seguir.

As características qualitativas são os atributos que tornam as demonstrações contábeis úteis para os usuários. As quatro primeiras características qualitativas são a compreensibilidade, relevância, confiabilidade e comparabilidade. (IASB, 2001, p. 49)

\section{Compreensibilidade}

Uma qualidade essencial das informações apresentadas nas demonstrações contábeis é que elas sejam prontamente entendidas pelos usuários. Para esse fim, presume-se que os usuários tenham um conhecimento razoável dos negócios, atividades econômicas e contabilidade e a disposição de estudar as informações com razoável diligência. Todavia, as informações sobre assuntos complexos que devam ser incluídas nas demonstrações contábeis, por causa da sua relevância para as necessidades de tomada de decisão pelos usuários, não devem ser excluídas meramente sob o pretexto de que seriam difíceis para certos usuários as entenderem. (IASB, 2001, p. 49)

\section{Relevância}

Para serem úteis, as informações devem ser relevantes às necessidades dos usuários em suas tomadas de decisões. As informações são relevantes quando influenciam as decisões econômicas dos usuários, ajudando-os a avaliar o impacto de eventos passados, presentes ou futuros, confirmando ou corrigindo as suas avaliações anteriores. (IASB, 2001, p. 49)

\section{a) Materialidade}

A relevância das informações é afetada pela sua natureza e materialidade. Em alguns casos, a natureza das informações, por si só, é suficiente para determinar sua relevância. (...) Em outros casos, tanto a relevância quanto a materialidade são importantes ...

As informações são relevantes se sua omissão ou distorção puder influenciar as decisões econômicas dos usuários tomadas com base nas demonstrações contábeis. A materialidade depende do tamanho o item ou do erro, julgado nas circunstâncias específicas de sua omissão ou distorção. Assim, a materialidade proporciona um 
patamar ou 'ponto de corte', em vez de ser uma característica qualitativa primária que a informação necessita ter para ser útil. (IASB, p.50)

\section{Confiabilidade}

Para ser útil, a informação deve ser confiável. A informação tem a qualidade de confiabilidade quando está livre de erros relevantes, e quando os usuários podem depositar confiança como representando fielmente aquilo que ela diz representar ou poderia razoavelmente esperar-se que represente.

A informação pode ser relevante, porém tão incerta em sua natureza ou representação que 0 seu reconhecimento pode ser potencialmente distorcido.

\section{a) Representação fidedigna}

Para ser confiável, a informação deve representar fielmente as transações e outros eventos que ela diz representar ou poderia razoavelmente esperar-se que represente." (...) "A maioria das informações financeiras está sujeita a algum risco de não atingir plenamente a representação fiel daquilo que pretende retratar...

b) Primazia da essência sobre a forma

Para que a informação represente fielmente as transações e outros eventos que ela se propõe a representar, é necessário que essas transações e eventos sejam contabilizados e apresentados de acordo com a sua essência ou substância e a sua realidade econômica, e não meramente sua forma legal. (IASB, p. 51)

c) Neutralidade

Para ser confiável, a informação contida nas demonstrações contábeis deve ser neutra, isto é, imparcial. As demonstrações contábeis não serão neutras se, pela escolha ou apresentação da informação, elas influenciarem a tomada de decisão ou um julgamento a fim de atingir um resultado ou desfecho predeterminado. (IASB, p. 51)

d) Prudência

Aqueles que preparam as demonstrações contábeis, entretanto, se deparam com as incertezas que inevitavelmente envolvem certos eventos e circunstâncias (...) A prudência consiste na inclusão de certa dose de cautela na formulação dos julgamentos necessários na elaboração de estimativas em certas condições de incertezas, no sentido de que ativos ou receitas não sejam superestimados e passivos ou despesas não sejam subestimados. (IASB, p. 51) 
e) Integridade

Para ser confiável, a informação constante das demonstrações contábeis deve ser completa, dentro dos limites da relevância e do custo. Uma omissão pode tornar a informação falsa ou distorcida e, assim sendo, não-confiável e deficiente em termos de sua relevância. (IASB, p. 51)

\section{Comparabilidade}

Os usuários devem poder comparar as demonstrações contábeis de uma entidade ao longo do tempo, a fim de identificar tendências na sua posição financeira e no seu desempenho. Os usuários devem também ser capazes de comparar as demonstrações contábeis de diferentes entidades, a fim de avaliar, em termos relativos, a sua posição financeira, os resultados e as mudanças na posição financeira. (IASB, p. 52)

A mesma organização apresenta o que denomina "limitações sobre a relevância e a confiabilidade", o que significa, neste caso, parâmetros a serem considerados além dos conceitos em si. São elas:

\section{Oportunidade das informações}

Se houver demora indevida em reportar a informação, ela poderá perder a relevância. A Administração poderá ter de estabelecer um equilíbrio entre reportar a informação na época oportuna e prover informações confiáveis. (IASB, p. 52)

Equilíbrio entre Custo e Benefício

o equilíbrio entre o custo e o benefício é uma limitação abrangente, em vez de uma característica qualitativa. Os benefícios decorrentes da informação devem exceder o custo de produzi-la. (IASB, p. 52)

Estas características qualitativas foram reunidas com base em pesquisas e práticas da contabilidade ao longo das últimas décadas. Como resultado, esse conjunto de atributos é útil para qualquer sistema de informação, podendo enriquecer a Ciência da Informação em diversas áreas de aplicação, especialmente a comunicação técnica. 


\subsubsection{As Demonstrações Contábeis e os usuários}

Para o IASB (2001, p. 36), dentre as diversas produções contábeis, os componentes das "Demonstrações Contábeis" são: "balanços patrimoniais, demonstrações de resultados ou das contas de lucros e perdas, demonstrações das origens e aplicações de recursos, notas explicativas e outras demonstrações anexas e material global, identificados como parte das demonstrações contábeis." Este conjunto de peças informativas possui formatos distintos e seu objetivo é "dar informações sobre a posição financeira, os resultados e as mudanças na posição financeira de uma entidade, que sejam úteis a um grande número de usuários em suas tomadas de decisão." (IASB, 2001, p. 46)

Esta mesma entidade descreve que as informações são para "necessidades comuns da maioria dos usuários", mas acrescenta:

Entretanto, as demonstrações contábeis não fornecem todas as informações que os usuários possam necessitar para tomar decisões econômicas, uma vez que elas retratam os efeitos financeiros de acontecimentos passados e não incluem necessariamente informações não-financeiras. (IASB, 2001, p. 46)

Certamente que, além do fato de informar eventos já ocorridos, existem outras limitações não citadas, como as dificuldades terminológicas. O que se depreende é que as ditas informações são dirigidas a usuários para "decisões econômicas", subentendendo que estes sejam já detentores de conhecimentos básicos da linguagem contábil.

A busca fundamental de um leitor de informações contábeis, com o objetivo de tomar alguma decisão econômica, segundo o IASB, é a "capacidade de a empresa gerar caixa (recursos financeiros)", considerando o tempo de ocorrência e a possibilidade de quantificação.

As decisões econômicas que são tomadas pelos usuários das demonstrações contábeis requerem uma avaliação da capacidade da entidade gerar caixa e equivalentes de caixa e da época e certeza de que tais recursos serão gerados. (IASB, 2001, p. 47) 
Uma vez que as principais ou as mais comuns decisões econômicas de um usuário de demonstrações contábeis (um investidor, por exemplo) são identificáveis, é possível apresentar estas informações de modo a suprir as consultas deste tipo de usuário. Isso não significa dizer que as demonstrações contábeis têm conteúdo escasso ou pouco abrangente. Ao contrário, elas descrevem a empresa, porém, em linguagem técnica.

O aspecto novo que esta pesquisa busca explorar é que estas avaliações de necessidades têm como atores principais sujeitos com formação contábil, ou seja, o que o "emissor" acredita ser a necessidade informacional do receptor. Um exemplo de questões atribuídas aos usuários por quem elabora as demonstrações contábeis é fornecido pelo próprio IASB:

A diretoria do IASC acredita que as demonstrações contábeis preparadas com tal finalidade satisfazem as necessidades comuns da maioria dos usuários. Isto porque quase todos os usuários estão tomando decisões econômicas, por exemplo, para:

a) decidir quando comprar, manter ou vender um investimento acionário;

b) avaliar a direção da entidade e a prestação de contas pela Administração;

c) avaliar a capacidade da entidade de pagar e proporcionar outros benefícios a seus empregados;

d) avaliar a segurança dos recursos financeiros emprestados à entidade;

e) determinar as políticas fiscais;

f) determinar a distribuição de lucros e dividendos;

g) preparar e usar estatísticas da renda nacional; ou

h) regulamentar as atividades das entidades (IASB, 2001, p. 42)

Em harmonia com as questões que apresenta como sendo próprias dos usuários, estes são identificados e classificados em 7 categorias principais: investidores, empregados, emprestadores, fornecedores e outros credores comerciais, clientes, governo e suas agencias e público em geral. A tabela a seguir explica, resumidamente, esses usuários e suas necessidades. 


\begin{tabular}{|c|c|}
\hline ábeis & lades \\
\hline $\begin{array}{l}\text { Investidores - são provedores de capital } \\
\text { de risco e seus analistas. Interesse: o risco } \\
\text { do investimento e o retorno que pode dar. }\end{array}$ & $\begin{array}{l}\text { Informações para subsidiar decisões de } \\
\text { compra, manutenção ou venda de } \\
\text { investimentos, assim como capacidade das } \\
\text { empresas de pagar dividendos. }\end{array}$ \\
\hline $\begin{array}{l}\text { Empregados e seus grupos } \\
\text { representativos. Interesse: a estabilidade e } \\
\text { lucratividade das empresas. }\end{array}$ & $\begin{array}{l}\text { Capacidade de pagamentos, benefícios das } \\
\text { empresas e oportunidades de emprego. }\end{array}$ \\
\hline $\begin{array}{ll}\begin{array}{l}\text { Emprestadores. } \\
\text { tempestividade } \\
\text { empresas. }\end{array} & \\
\text { emple capacidade e } \\
\end{array}$ & $\begin{array}{l}\text { Informações sobre a capacidade de } \\
\text { pagamento do empréstimo e de juros nos } \\
\text { vencimentos. }\end{array}$ \\
\hline $\begin{array}{l}\text { Fornecedores } \\
\text { comerciais. Interesse: capacidade e } \\
\text { tempestividade de pagamento das } \\
\text { empresas. }\end{array}$ & $\begin{array}{l}\text { As mesmas dos emprestadores, mas } \\
\text { provavelmente por um período de tempo } \\
\text { menor. }\end{array}$ \\
\hline $\begin{array}{ll}\text { Clientes. } & \text { Interesse: } \\
\text { operacional de uma empresa }\end{array}$ & $\begin{array}{l}\text { Informações que indiquem a continuidade da } \\
\text { empresa, especialmente nos } \\
\text { relacionamentos de longo prazo ou se o } \\
\text { cliente dela depende. }\end{array}$ \\
\hline $\begin{array}{l}\text { Governo e suas agências. Interesse: a } \\
\text { destinação dos recursos e nas atividades das } \\
\text { empresas. }\end{array}$ & $\begin{array}{l}\text { Informações que possam regulamentar as } \\
\text { atividades das empresas, estabelecer } \\
\text { políticas fiscais e dados estatísticos. }\end{array}$ \\
\hline $\begin{array}{l}\text { Público. Interesse: as diversas formas de } \\
\text { influência da empresa e sua contribuição } \\
\text { para a economia local. }\end{array}$ & $\begin{array}{l}\text { Informações sobre as tendências e a } \\
\text { evolução recente na prosperidade da } \\
\text { empresa e no campo de atividade. }\end{array}$ \\
\hline
\end{tabular}

Fonte: IASB, 2001, p. 45

\subsection{A mediação institucional de Informações Contábeis}

As informações contábeis apresentam as mesmas características de outras informações divulgadas pelas empresas, porém com a particularidade de serem expressas em linguagem de especialidade.

A informação é qualificada como um instrumento modificador da consciência do homem, adequadamente assimilada, produz conhecimento e modifica o estoque mental de saber do indivíduo, trazendo benefícios para seu desenvolvimento e para o bem-estar da sociedade em que vive. (BARRETO, 2002, p. 56) 
Além disso, especialmente por seu aspecto especializado, a linguagem contábil exige contextualização e um nível de conhecimento do código.

Um ato de comunicação se efetiva quando um emissor, remetente envia uma mensagem a um destinatário, receptor. Para se realizar de forma eficaz a mensagem necessita de um contexto de referência e este contexto precisa ser acessível ao receptor (...). É necessário ainda um código, total ou parcialmente comum ao emissor e ao receptor e finalmente um contacto, isto é, um canal físico e uma conexão psicológica entre o emissor e o receptor, que o capacite a entrarem e permanecerem em contato. (BARRETO, 2002, p. 50).

Permitir ao investidor entrar em contato com a empresa por um canal que permaneça aberto é parte dos motivos da legalização deste serviço. Quando se fala em divulgação, exigida por lei, de informações contábil-financeiras, a referência imediata é a Companhia Aberta - aquela que tem fins lucrativos, que presta contas a seus acionistas e que precisa de investidores.

Ao determinar o estabelecimento de um diretor de relações com investidores para este tipo de empresa, a Comissão de Valores Mobiliários (CVM) oficializa a abertura de um canal de diálogo entre os emissores da informação e os usuários, apresentado na seção 3 (item 3.2). Um profissional dedicado à comunicação com investidores, em um ambiente de busca de lucratividade, permitiu a aplicação de conceitos oriundos das teorias de Relações Públicas. Especialmente no relatório anual, que é o informe mais completo publicado pelas companhias abertas, percebe-se uma tendência de divulgação de uma imagem próspera da empresa juntamente com as informações contábeis.

É bom que fique claro que comunicação empresarial é uma atividade global, multidisciplinar, com objetivos específicos, que visa estabelecer um nível de informação estável e criar um conceito próprio para a empresa, do qual ela irá usufruir no mercado. (SHMIDT, 2001, p. 163).

Criar um "conceito próprio para a empresa", conforme a citação acima, não é o motivo deste canal de comunicação estabelecido pela Comissão de Valores Mobiliários (CVM), porém a empresa é um sistema, ou seja, opera com uma visão que norteia todas as suas atividades. Portanto, a estruturação de uma área somente 
para atender ao mercado, desvinculada das áreas afins, como Assessoria de Imprensa, pode representar um novo canal para o fortalecimento da imagem institucional planejada pela empresa.

Do lado positivo, uma organização pode ter como objetivo maximizar seus investimentos em comunicação, fazendo das lideranças de seus públicos de interesse possíveis porta-vozes de suas mensagens preferenciais e de seus objetivos (políticos, comerciais, estratégicos etc.). (MESTIERI, 2001, p. 19).

Outro conceito de Relações Públicas que pode ser notado, nesta mediação, é o uso da comunicação dirigida.

Comunicação dirigida é o processo que tem por finalidade transmitir ou conduzir informações para estabelecer comunicação limitada, orientada e freqüente com determinado número de pessoas homogêneas e identificadas. (ANDRADE, 1985 apud FERREIRA, 2001, p. 73).

Da mesma forma, a aproximação com os usuários, classificando-os e segmentando-os para o aprimoramento da forma de divulgação e dos serviços auxiliares de mediação, também é uma técnica da mesma teoria.

Embora esta abordagem de monitoramento de públicos e de integração dos recursos de comunicação, para seu uso de forma dirigida e segmentada, possa parecer um conceito novo para a área, esta sempre foi uma recomendação e uma prática de relações públicas. (MESTIERI, 2001, p. 20).

A mediação institucional das informações contábeis é um campo de aplicação de conceitos vindos da Contabilidade, da Análise Documentária e de Relações Públicas. O estudo dos serviços informacionais das companhias abertas permite identificar e a descrever melhor essas técnicas. 


\subsubsection{A divulgação legal de informações contábeis no Brasil}

A forma tradicional de veiculação das informações contábeis ocorre por meio de relatórios. Existem relatórios contábeis que são obrigatórios, por lei, para as empresas de capital aberto. Segundo a Lei 6404, de 15 de dezembro de 1976, conhecida como lei societária, as demonstrações obrigatórias são:

\footnotetext{
Seção II

DEMONSTRAÇÕES FINANCEIRAS

Disposições Gerais

Art. 176 Ao fim de cada exercício social, a Diretoria fará elaborar, com base na escrituração mercantil de companhia, as seguintes demonstrações financeiras, que deverão exprimir com clareza a situação do patrimônio da companhia e as mutações ocorridas no exercício:

I - balanço patrimonial;

II - demonstração dos lucros ou prejuízos acumulados;

III - demonstração do resultado do exercício;

IV - demonstração das origens e aplicações de recursos. (...)

$\S 4^{\circ}$ As demonstrações serão complementadas por notas explicativas e outros quadros analíticos ou demonstrações contábeis necessários para esclarecimento da situação patrimonial e dos resultados do exercício.
}

Dentre os relatórios não obrigatórios destacam-se a Demonstração do Fluxo de Caixa e a Demonstração do Valor Adicionado. O anteprojeto de lei que reformula a Lei das S.A. apresenta, como uma das alterações, a inclusão destes dois relatórios como obrigatórios e a exclusão da Demonstração das Origens e Aplicações de Recursos.

O conteúdo gráfico e semântico de cada uma dessas demonstrações, citadas no anteprojeto de lei, está resumidamente exposto no item "Publicação legal de Demonstrações contábeis", nos Anexos (p.168). 


\subsection{O Sistema Financeiro Nacional}

As economias desenvolvidas ou em acelerado processo de desenvolvimento têm como características comuns taxas de poupança elevadas, alta eficiência em sua intermediação ou a combinação das duas. Dito de outro modo, o crescimento está associado a elementos incentivadores da formação da poupança e de sua intermediação eficiente, que a torne acessível para quem quer e possui competência para investir. Assim como nas empresas, o crescimento da economia é o resultado do aumento contínuo da capacidade de produção. Essa expansão, segundo Faria (2004), depende de novos investimentos que produzam dois efeitos:

- Acumulação de capital produtivo (riqueza), e

- Aumento de produtividade.

Regulado pelo Conselho Monetário Nacional, o Sistema Financeiro Nacional é composto por um conjunto de instituições e sua existência permite a negociação entre as instituições carentes de recursos e as geradoras de reservas de recursos. Esse movimento é o principal responsável pelo crescimento de uma economia.

O sistema financeiro nacional pode ser entendido como um conjunto de instituições financeiras e instrumentos financeiros que visam, em última análise, transferir recursos dos agentes econômicos (pessoas, empresas, governo) superavitários para os deficitários. (ASSAF NETO, 2000, p. 61)

O quadro a seguir resume o conjunto das instituições que compõem o sistema e sua hierarquia: 


\begin{tabular}{|c|c|c|c|}
\hline \multirow{9}{*}{\multicolumn{2}{|c|}{$\begin{array}{l}\text { Sistema Financeiro } \\
\text { Nacional }\end{array}$}} & \multirow[b]{4}{*}{$\begin{array}{l}\text { Subsistema } \\
\text { Normativo }\end{array}$} & \begin{tabular}{l|l} 
Conselho Monetário & Comissões \\
Nacional - CMN & Consultivas \\
\end{tabular} \\
\hline & & & Banco Central do Brasil - BACEN \\
\hline & & & Comissão de Valores Mobiliários - CVM \\
\hline & & & $\begin{array}{l}\text { Instituições Especiais: } \\
\text { Banco do Brasil - BB } \\
\text { Banco Nacional de Desenvolvimento Econômico } \\
\text { e Social - BNDES } \\
\text { Caixa Econômica Federal - CEF }\end{array}$ \\
\hline & & \multirow{5}{*}{$\begin{array}{l}\text { Subsistema de } \\
\text { Intermediação }\end{array}$} & $\begin{array}{l}\text { Instituições Financeiras Bancárias: } \\
\text { Bancos Comerciais } \\
\text { Bancos Múltiplos } \\
\text { Caixas Econômicas }\end{array}$ \\
\hline & & & $\begin{array}{l}\text { Sistema Brasileiro de Poupança e Empréstimo- } \\
\text { SBPE }\end{array}$ \\
\hline & & & $\begin{array}{l}\text { Instituições Auxiliares: } \\
\text { Bolsas de Valores } \\
\text { Sociedades Corretoras de Valores Mobiliários } \\
\text { Sociedades Distribuidoras de Valores Mobiliários } \\
\text { Agentes autônomos de investimento }\end{array}$ \\
\hline & & & Instituições Não Financeiras \\
\hline & & & $\begin{array}{l}\text { Instituições Financeiras Não Bancárias: } \\
\text { Bancos de investimento } \\
\text { Bancos de desenvolvimento } \\
\text { Sociedades de crédito, financiamento e } \\
\text { investimento } \\
\text { Sociedades de Arrendamento Mercantil } \\
\text { Cooperativas de Crédito } \\
\text { Sociedades de Crédito Imobiliário } \\
\text { Associações de Poupança e Empréstimo } \\
\end{array}$ \\
\hline
\end{tabular}

Assaf Neto, 2000, p. 62 e 64

Ao subsistema Normativo cabe o estabelecimento do controle e de diretrizes de operação das instituições financeiras. O outro subsistema, o de Intermediação, também chamado operativo, compõe-se das instituições financeiras que trabalham com a intermediação de recursos, conforme Assaf Neto (2000).

A partir dessa contextura macroeconômica, cabe definir as instituições que apresentam relação mais próxima com o objeto da pesquisa. São elas, a Comissão de Valores Mobiliários (CVM), cuja influência incide diretamente no comportamento dos agentes financeiros envolvidos nas Bolsas de Valores por meio de instruções normativas que regulamentam, entre outros, as normas de divulgação de 
informações por parte das companhias abertas; e a própria Bolsa de Valores, que oferece o ambiente onde ocorrem as negociações de títulos e valores mobiliários.

\subsubsection{Comissão de Valores Mobiliários - CVM}

É uma entidade autárquica em regime especial, vinculada ao Ministério da Fazenda, criada pela Lei no 6.385/76, com autoridade administrativa independente, ausência de subordinação hierárquica e administrada por um Presidente juntamente com quatro Diretores, nomeados pelo Presidente da República. Também possui autonomia financeira e orçamentária e sua diretoria é órgão de deliberação colegiada.

\section{Objetivos}

A CVM tem por finalidade assegurar o funcionamento eficiente e regular dos mercados da bolsa e de balcão, assim como proteger os investidores do mercado contra emissões irregulares de valores mobiliários, contra quaisquer atos ilegais de gestores das companhias abertas ou de administradores de carteira de valores mobiliários e contra o uso de informação relevante não divulgada no mercado de valores mobiliários.

Ainda dentro do funcionamento regular do mercado, a CVM deve evitar ou coibir modalidades de fraude ou manipulação destinadas a criar condições artificiais de demanda, oferta ou preço dos valores mobiliários negociados e assegurar o acesso do público a informações sobre os mesmos e as companhias que os tenham emitido.

\section{Atribuições}

Compete à CVM fiscalizar e disciplinar:

- A emissão e distribuição de valores mobiliários no mercado; 
- A negociação e intermediação no mercado de valores mobiliários e no mercado de derivativos;

- A organização, funcionamento e operações das bolsas de valores e de mercadorias e futuros;

- A administração de carteiras e a custódia de valores mobiliários;

- A auditoria das companhias abertas;

- Os serviços de consultor e de analista de valores mobiliários.

$O$ detalhamento completo das funções e da organização da CVM encontrase nos Anexos desta tese.

\section{o trabalho da CVM relacionado à divulgação de informações contábil-financeiras}

A CVM tem extensa produção normativa que orienta a publicação e divulgação de informações para as empresas de capital aberto. Conforme o Ofício Circular CVM/SNC/SEP No 01 de 2005:

O objetivo da regulação contábil para o mercado de capitais está vinculado ao funcionamento das empresas na forma corporativa, ou seja, no conjunto de relações com os interessados no funcionamento da empresa (stakeholders) capaz de produzir efeitos econômicos e sociais. Esse objetivo relaciona-se, também, ao papel dos administradores, que têm responsabilidade primária sobre as contas da companhia, e com o papel dos auditores que expressam a sua opinião sobre as demonstrações contábeis e assumem coresponsabilidade pública sobre essa informação.

A regulação se constitui no arcabouço formal sobre o qual se dá a produção das informações contábeis e estabelece as condições mínimas para que se conheça a situação econômico-financeira da empresa. Isso, entretanto, não esgota as possibilidades de atendimento às necessidades informacionais dos agentes de mercado externos à companhia aberta e nem supre a velocidade com que essas informações devem chegar aos interessados. É necessário que a companhia faça o esforço permanente de aperfeiçoamento dessas informações e procure garantir a adequação e razoabilidade de seus procedimentos nesse esforço, particularmente se for considerado o problema da globalização das informações contábeis associado ao livre fluxo de capitais. 
Mais adiante, no mesmo Ofício, a CVM comenta a evolução das divulgações legalmente obrigatórias e as barreiras ao seu desenvolvimento.

O sentido principal da evolução regulatória no Brasil está na convergência com os pronunciamentos internacionais e, para isso, o Instituto Brasileiro de Contadores (IBRACON) e a CVM vêm se empenhando na adaptação, para o ambiente contábil brasileiro, das regras emitidas pelo International Accounting Standards Board (IASB). Estas regras são os International Financial Reporting Standards IFRS.

As instruções normativas da CVM, mais aplicáveis a esta pesquisa, podem ser consultadas nos anexos.

Segundo o Presidente do Banco Central, Marcelo Trindade, estas normas regulamentares, como as resumidas acima,

põe o Brasil em pé de igualdade (ou mesmo em situação de vantagem) com o que há de mais moderno na regulamentação mundial. $E$ isto é fundamental em um mercado de capitais globalizado. (Entrevista. Revista RI, no 76, junho/2004, p. 5)

\subsubsection{Bolsa de Valores}

As bolsas de valores são associações civis sem finalidades lucrativas, cujos patrimônios são constituídos por títulos patrimoniais adquiridos por seus membros, as sociedades corretoras. (ASSAF NETO, 2000, p.75).

Essas instituições devem oferecer um local onde são negociados os títulos e valores mobiliários, de modo livre e aberto, obedecendo a regras claras, de forma a propiciar liquidez às negociações que ali são realizadas por meio de pregões contínuos e ainda fornecendo informações sobre todas a operações, segundo Assaf Neto (2000).

No Brasil, uma das vantagens mais procuradas pelas empresas, ao angariar recursos na Bolsa de Valores, é a taxa de juros, que é inferior aos juros bancários. Para que uma companhia aberta atinja um alto grau de interesse do investidor, diversas medidas devem ser implementadas, além das exigências legais. 
As mais importantes dentre estas são as relacionadas à governança corporativa. 0 Instituto Brasileiro de Governança Corporativa (IBGC) assim define esta expressão:

Governança corporativa é o sistema pelo qual as sociedades são dirigidas e monitoradas, envolvendo os relacionamentos entre Acionistas/Cotistas, Conselho de Administração, Diretoria, Auditoria Independente e Conselho Fiscal. As boas práticas de governança corporativa têm a finalidade de aumentar o valor da sociedade, facilitar seu acesso ao capital e contribuir para a sua perenidade.

Quando aplicada, esta forma de gestão visa garantir eqüidade de tratamento e de direitos entre os sócios, transparência das decisões e seus resultados, prestação de contas e conformidade com as regras estabelecidas na empresa (IBGC). Para a empresa, todo este esforço significa ter seus títulos classificados em um nível melhor, o que os torna mais atraentes para os investidores e mais líquidos para negociação.

\section{Histórico da Bolsa de Valores}

Segundo publicações da BOVESPA (2005), a Bolsa de Valores de São Paulo - BOVESPA foi fundada em 23 de agosto de 1890 e, até meados da década de 60 , ela e as demais bolsas brasileiras eram entidades oficiais corporativas, vinculadas às secretarias de finanças dos governos estaduais e compostas por corretores nomeados pelo poder público. Na década seguinte, houve reformas no sistema financeiro nacional e do mercado de capitais, que vieram a ser implementadas em 1965/66. Com isso, as bolsas assumiram a característica institucional que mantêm até hoje, transformando-se em associações civis sem fins lucrativos, com autonomia administrativa, financeira e patrimonial. A antiga figura individual do corretor de fundos públicos foi substituída pela da sociedade corretora, empresa constituída sob a forma de sociedade por ações nominativas ou por cotas de responsabilidade limitada.

Quanto à autonomia, a Bolsa de Valores de São Paulo é uma entidade auto-reguladora que opera sob a supervisão da Comissão de Valores Mobiliários (CVM). 
Os avanços tecnológicos permitiram que fossem iniciadas em 1990 as negociações através do Sistema de Negociação Eletrônica Computer Assisted Trading Sistem (CATS) com operação simultânea com o sistema tradicional de Pregão Viva Voz. Em 1997, foi implantado com sucesso o novo sistema de negociação eletrônica da BOVESPA, o Mega Bolsa. Além de utilizar um sistema tecnológico altamente avançado, o Mega Bolsa amplia o volume potencial de processamento de informações e permite que a BOVESPA consolide sua posição como o mais importante centro de negócios do mercado latino-americano.

A modernização tecnológica tem possibilitado grande evolução das atividades da BOVESPA. Em 1999 foram lançados o Home Broker e o After-Market, ambos meios para facilitar e tornar viável a desejada participação do pequeno e médio investidor no mercado. O Home Broker permite que o investidor, por meio do site das Corretoras na Internet, transmita sua ordem de compra ou de venda diretamente ao Sistema de Negociação da BOVESPA. Para isso, o sistema da BOVESPA é único no mundo. Comparativamente, nos Estados Unidos, as ordens são executadas, em sua maioria, fora do âmbito das bolsas de valores e, portanto, nem sempre ao melhor preço. O After-Market é outra inovação da BOVESPA, pioneira em termos mundiais, que oferece a sessão noturna de negociação eletrônica. Além de atender aos profissionais do mercado, este mecanismo também é interessante para os pequenos e médios investidores, pois permite que enviem ordens por meio da Internet também no período noturno.

Atualmente, a BOVESPA é o maior centro de negociação com ações da América Latina com o estabelecimento do acordo histórico para a integração de todas as bolsas brasileiras em torno de um único mercado de valores - o da BOVESPA.

\section{Um resumo sobre o funcionamento do mercado financeiro}

"Mercado Financeiro" é uma expressão que representa o conjunto de instituições dedicadas a manter um fluxo de recursos entre poupadores e investidores. Os principais agentes são o mercado bancário (que entre outros, é 
responsável pelo crédito e financiamento para investimento e consumo, no papel de intermediadores das operações) e o mercado de capitais (que realiza a intermediação de ativos e não de crédito, sendo composto por corretoras, distribuidoras e bancos de investimento).

Conceituando, as Sociedades corretoras "são instituições que efetuam, com exclusividade, a intermediação financeira nos pregões das bolsas de valores, das quais são associadas mediante a aquisição de um título patrimonial." (Assaf Neto, 2000, p. 76). E as sociedades distribuidoras "são também instituições intermediadoras de títulos e valores mobiliários, cujos objetivos básicos se assemelham bastante aos das corretoras" (ASSAF NETO, 2000, p. 76).

\section{O que se negocia no mercado de ações}

São considerados valores mobiliários emitidos por companhias abertas:

- ações: títulos nominativos, negociáveis, representativos de propriedade de uma fração do capital social de uma sociedade por ações.

- debêntures: títulos nominativos, negociáveis, representativos de dívidas de médio e longo prazos contraídas pela companhia junto aos debenturistas.

Entre os principais papéis negociados, conforme Assaf Neto (2000), estão ainda:

- Opções: ou melhor, opções sobre ações são títulos que representam um direito de compra (direito de adquirir no futuro um lote de ações a um determinado preço) ou venda (direito de vender um lote de ações a um preço fixado) válido durante um intervalo de tempo, negociadas em Bolsa mediante o pagamento de um prêmio;

- Depositary Receipts - títulos também negociados em Bolsa e lastreados em ações de uma sociedade instalada em outro país. São recibos de depósitos e quando emitidos nos EUA, denominam-se ADRs; 
- Commercial papers: - pode ser entendido como uma espécie de nota promissória de curto prazo, que as empresas emitem para financiar seu capital de giro.

O mercado de ações pode ser primário (captação de recursos para a empresa, ou seja, quem vende as ações é a companhia, usando os recursos para se financiar). Para ter acesso a essa fonte de recursos, a empresa deve proceder à sua abertura de capital, apresentando a documentação legal e contábil para os registros na CVM e na Bolsa de valores. Essas ações precedem a colocação dos papéis e o repasse dos recursos para a companhia. Pode também ser secundário (troca a propriedade do título, ou seja, o vendedor é um investidor que se desfaz das ações para reaver o seu dinheiro, trocando a propriedade das ações). Essa negociação proporciona liquidez ao mercado primário.

Quanto ao sistema de negociação, a Bolsa opera por pregão ou sistema eletrônico, sendo que o preço e as quantidades negociadas são abertos ao público. Na descrição de Assaf Neto (2000, p. 75), a Bolsa tem responsabilidade "pela fixação de um preço justo, formado por consenso de mercado mediante mecanismos de oferta e de procura." Para tanto, existe uma constante supervisão sobre as regras para negociação, fiscalização dos negócios realizados e equalização do nível de informação.

Para que o processo de formação dos preços seja mais transparente e atraente, existem as chamadas práticas eqüitativas de mercado. Essas práticas garantem que todos que comprarem e venderem ações em Bolsa:

Terão o mesmo tratamento

Obedecerão aos mesmos procedimentos.

Terão idêntico acesso à informação. (CAVALCANTE e MISUMI, 2003, p. 69) 
A sistematização formal e pública das negociações de ações apresenta algumas características fundamentais, segundo Cavalcante e Misumi (2003), resumidas no quadro abaixo.

\begin{tabular}{|c|c|c|}
\hline $\begin{array}{l}\text { Legitimar compra e } \\
\text { venda }\end{array}$ & $\begin{array}{l}\text { Comprador deposita numerário } \\
\text { Vendedor comparece com as } \\
\text { ações }\end{array}$ & $\begin{array}{l}\text { Corretora confirma existência do } \\
\text { valor, e que as ações estão } \\
\text { liberadas para venda. }\end{array}$ \\
\hline $\begin{array}{l}\text { Negócios realizados } \\
\text { durante o pregão }\end{array}$ & $\begin{array}{l}\text { Pregão = leilão público } \\
\text { Encontro da oferta com a } \\
\text { demanda. } \\
\text { Ações: quantidade, companhia, } \\
\text { tipo, forma de emissão, direitos e } \\
\text { preço. }\end{array}$ & $\begin{array}{l}\text { Pregão pelos sistemas de: } \\
\text { Chamada (call) } \\
\text { Postos de negociação (trading } \\
\text { posts) } \\
\text { Eletrônico (Mega Bolsa). }\end{array}$ \\
\hline $\begin{array}{l}\text { Pregão tem preços } \\
\text { públicos }\end{array}$ & $\begin{array}{l}\text { Preços e quantidades apregoados } \\
\text { de viva voz para conhecimento } \\
\text { geral. } \\
\text { Nos terminais eletrônicos, oferta e } \\
\text { demanda se caracterizam nos } \\
\text { monitores. }\end{array}$ & $\begin{array}{l}\text { Preços e quantidades } \\
\text { determinam valor venal } \\
\text { instantâneo e liquidez das ações }\end{array}$ \\
\hline $\begin{array}{l}\text { Fechamento } \\
\text { negócios }\end{array}$ & $\begin{array}{l}\text { Corretoras do vendedor e do } \\
\text { comprador anunciam em alta voz: } \\
\text { Fechado! }\end{array}$ & $\begin{array}{l}\text { Fechado! É a palavra mágica dos } \\
\text { negócios de Bolsa. Depois de } \\
\text { fechado, um negócio está } \\
\text { formalmente concluído. O } \\
\text { restante é } \\
\text { administrativo. }\end{array}$ \\
\hline
\end{tabular}

Fonte: Cavalcante e Misumi (2003, p. 70)

As formas de negociação principais ocorrem por meio dos operadores que executam as orientações que os investidores passam por meio das corretoras ou por meio do Home Broker (os Home Brokers das corretoras estão interligados aos sistemas da BOVESPA e permitem que o investidor envie, automaticamente, através da internet, ordens de compra e venda de ações).

A denominada auto-regulação da Bolsa ocorre em três etapas: antes do pregão (com o acompanhamento e divulgação de Informações), durante o pregão (acompanhamento das negociações - oscilação e quantidade) e após o pregão (análise de operações atípicas). 


\section{Tipos de investidores}

Os investidores costumam ser classificados como individuais ou institucionais. Os institucionais são

administradores profissionais do dinheiro de outras pessoas. Eles são pagos para alcançarem as taxas de retorno mais altas sobre os investimentos que fazem em ações, títulos de renda fixa e em outros ativos. (...) O universo dos investimentos é formado por diversos grupos de investidores institucionais. Entre eles, os maiores são os fundos de pensões, os bancos, as companhias de seguros, os fundos mútuos, as fundações, os sindicatos e as firmas administradoras de investimentos. (MAHONEY, 1999, p. 8)

Os investidores individuais, também chamados de "investidor pessoafísica", são aqueles que aplicam no mercado financeiro sem estarem vinculados ao capital de nenhuma empresa. Esse tipo de investidor é que funda os clubes de investimento, quando se agrupa para aumentar o montante do capital a ser aplicado.

Apresentado o referencial teórico que embasa a pesquisa, passamos, na próxima seção, ao objeto da pesquisa - a mediação da informação contábil e seus atores e processos específicos. 


\section{seção 3: Análise Descritiva das "Relações com Investidores"}

\subsection{Conceito e finalidade das Relações com Investidores}

A área de contabilidade e controladoria das empresas detém o conjunto dos dados que vão compor as demonstrações contábeis, as quais devem ser apresentadas à Comissão de Valores Mobiliários (CVM), aos órgãos governamentais para tributação (FISCO) e aos demais destinatários. O incremento dos conceitos de comunicação, especialmente de Relações Públicas, ao conhecimento técnico do negócio é o traço mais marcante da área de Relações com Investidores.

O Instituto Brasileiro de Relações com Investidores (IBRI), assim como a revista RI (Relações com Investidores) $\mathrm{n} . .06$ 66, de agosto de 2003, fornecem a seguinte definição para a expressão "relações com investidores":

\footnotetext{
É o conjunto de atividades, métodos, técnicas e práticas que, direta ou indiretamente, propicie a interação das áreas de Contabilidade, Planejamento, Comunicação, Marketing e Finanças, com o propósito de estabelecer uma ligação entre a administração da empresa, os acionistas (e seus representantes) e os demais agentes que atuam no mercado de capitais e que integram a comunidade financeira nacional ou internacional.
}

São os executivos e analistas de Relações com Investidores que elaboram e executam os processos de comunicação e mediação institucional de informações contábil-financeiras para o público, em sua maioria, profissionais do mercado de capitais, os quais representam os investidores.

O fornecimento de relatórios contábeis de uma empresa, acompanhado de explicações com forte embasamento técnico, tem reflexo no risco que aquele investimento representa, uma vez que tende a esclarecer pontos de dúvidas sobre o que se pode prever a partir dos números relatados. Guerreiro (1989) afirma que há um aumento de valor da informação relacionado à melhoria de sua utilização por quem a recebe. $\mathrm{O}$ mesmo autor considera como inferências básicas: 
A informação é um recurso da organização, que tem um valor e um custo.

A informação tem valor porque reduz a incerteza a respeito das condições ambientais onde a empresa atua.

$A$ redução de incerteza permite a tomada de melhores decisões. (GUERREIRO, 1989, p.137)

Portanto, as atribuições da área de Relações com Investidores estão associadas, em última instância, às decisões dos investidores em comprar ou não títulos da empresa e a qual preço.

Um importante objetivo do executivo de RI é criar o mais alto nível de conhecimento sobre sua empresa no mercado. Conhecimento vem da informação. Assim, um mercado bem informado atribui a uma ação o preço que representa o valor justo da empresa. A falta da informação causa incerteza sobre a empresa e sobre seu futuro desempenho. Essa incerteza cria medo entre os investidores, o que os leva a não comprar ações. $A$ falta do interesse de compra impede que a ação suba. (RI - Teoria \& prática. n.3, p.7, maio, 1998.)

A finalidade da área de Relações com Investidores compreende "ajudar a empresa a alcançar o seu justo valor. Isso ocorre quando as melhores informações disponíveis estão sendo refletidas no preço das ações." (MAHONEY, 1997, p.5). Significa dizer que, quando a empresa fornece informação satisfatória, o preço de suas ações alcança o valor correto. Em outro capítulo, o mesmo autor argumenta que os profissionais da área acreditam ser a contribuição essencial de relações com investidores "ajudar a preencher a lacuna da informação no processo que os investidores utilizam para fixar o valor dos títulos das empresas." (MAHONEY, 1997, p. 16). Esse objetivo se alinha à definição de informação, presente na Teoria da Informação, que diz:

a informação é uma redução de incerteza, oferecida quando se obtém resposta a uma pergunta (SHANNON, 1975, p.53). A incerteza refere-se à quantidade de respostas possíveis que conhecemos, apesar de não sabermos qual delas é a verdadeira.

Para definirmos a informação no sentido da Teoria da Informação é necessário conhecer-se o tamanho da ignorância, isto é, a dimensão da classe das respostas possíveis.(EPSTEIN, 1988, p.35) 
Para dimensionar o grau de conhecimento dos usuários, é pratica comum a adoção da técnica de Relações Públicas denominada de "auditoria de opinião".

A auditoria de opinião destina-se ao levantamento do perfil real da organização pública ou privada, do nível de conhecimento e aceitação de seus produtos e serviços, do grau de satisfação de seus públicos e ao levantamento de desempenho de gestões administrativas. Também tem por objetivo o levantamento de conceitos e preconceitos emitidos pelas lideranças dos diversos públicos que possam influenciar direta ou indiretamente, uma organização, um produto, um projeto ou uma decisão. (MESTIERI, 2001, p.21).

Esse setor, dentro das empresas, concentra esforços para ampliar o conhecimento dos usuários de seus serviços informacionais. Especialmente com o emprego de tecnologia, os usuários possuem cadastro, passando a fazer parte de um banco de dados da empresa. Dessa forma o setor de Relações com investidores tem a possibilidade de estruturar os usuários em grupos de acordo com seu nível de linguagem, ou melhor, seu nível de conhecimento técnico. Este é o principal recorte, porém, são selecionados usuários por outros aspectos, como o tempo que o investidor tem ações da empresa, sua faixa etária, o volume de ações adquirido etc., de forma que podem ser organizados eventos específicos para aproximação com cada segmento.

Além dos levantamentos feitos pelas empresas, envolvendo os usuários, existem também pesquisas realizadas por entidades do setor. Em 2002, a empresa americana Erdos \& Morgan promoveu uma pesquisa, publicada na revista IR Magazine, sobre empresas da América Latina. Esta pesquisa identificou, em questão aberta, alguns fatores essenciais para um programa de Relações com Investidores, apresentados a seguir, por ordem de importância:

1. Acesso e comunicação com pessoas chaves na empresa

2. Pontualidade e demonstração de interesse no atendimento

3. Honestidade e integridade

4. Consistência e confiabilidade dos dados

5. Disclosure claro e completo 
Pesquisas desse tipo também norteiam a criação e o desenvolvimento de produtos de mediação direcionados aos investidores, pois representam um retorno avaliativo da intermediação e dos produtos de comunicação gerados pelas empresas.

\title{
3.2 A constituição da função Relações com Investidores nas
}

\section{empresas}

Nos Estados Unidos, país com as maiores bolsas de valores do mundo, as relações com investidores têm se desenvolvido rapidamente nos últimos 30 anos, tendo como embasamento uma combinação das áreas de relações públicas e finanças. $O$ instituto que congrega os profissionais dessa área, National Institute of Investor Relations (NIRI) foi fundado em 1969.

As primeiras comunicações de relações com investidores foram bastante influenciadas pelo conceito de marketing, conforme a visão de Relações Públicas, o que se pode verificar pelo traço promocional presente.

\begin{abstract}
Neste sentido, podemos definir marketing como o "composto de todas as atividades planejadas e estruturadas que visam o mercado. (YANAZE, 2001 p. 46)

Devemos entender que marketing é a filosofia empresarial que norteia a ação da empresa no mercado e que relações públicas, como propaganda e promoção de vendas, são atividades de comunicação que aproximam a empresa de seu público, informando, persuadindo e convencendo-o a adotar uma postura positiva em relação a ela. (YANAZE, 2001 p. 59).
\end{abstract}

Porém, com o amadurecimento das funções de relações com investidores, também houve uma concentração do uso de terminologia contábil-financeira nos serviços informacionais prestados. Dessa forma, a presença dos conceitos de finanças e a linguagem mais técnica de negócios foram ganhando consistência, como observa Mahoney:

Agora, passada a fase da impressão, as relações com investidores estão sendo alimentadas pelos princípios das finanças. Isso é tão lógico quanto necessário: os mercados de capitais se institucionalizaram, as instituições seguem sofisticados modelos 
financeiros em seus investimentos, logo, a informação precisa ser financeiramente dirigida. (MAHONEY, 1997, P.15)

No Brasil, em dezembro de 1993, por meio da instrução normativa $n^{\circ} 202$, a Comissão de Valores Mobiliários (CVM) oficiou a exigência de que as companhias abertas nomeassem um diretor para responder ao mercado, então designado "diretor de relações com o mercado". Foi o início da institucionalização da área, a qual passou a ser tratada como "relações com investidores" na instrução CVM no 309, de 10 de junho de 1999, conforme artigos abaixo:

Art. 50 - Para a companhia ser registrada na CVM, o estatuto social
ou o Conselho de Administração deve atribuir a um diretor a função
de relações com investidores, que poderá ou não ser exercida
cumulativamente a outras atribuições executivas.
Art. 60 - O diretor de relações com investidores é responsável pela
prestação de informações ao público investidor, à CVM e, caso a
companhia tenha registro em bolsa de valores ou mercado de balcão
organizado, a essas entidades, bem como manter atualizado o
registro de companhia (arts. 13,16 e 17). (NR)

Esta função é condição necessária para que a companhia aberta obtenha seu registro, pois para obtê-lo a empresa deve apresentar à Comissão de Valores Mobiliários (CVM) a "ata de reunião do Conselho de Administração ou da Assembléia Geral que houver designado o diretor de relações com investidores" (art. 70, IN 309/1999).

O Instituto Brasileiro de Relações com Investidores (IBRI), foi fundado em 1997, como uma sociedade civil de direito público, sem fins lucrativos, que atualmente reúne mais de 270 profissionais ligados à área de Relações com Investidores. Esse marco coincide com a história do desenvolvimento desta área no país. Esta função, quando de sua criação nas empresas nacionais, consistiu em um acúmulo de tarefas por executivos das áreas de Controladoria, Finanças e similares.

...no Brasil, as empresas iniciaram, basicamente, suas atividades de RI no início desta década. Portanto, estamos completando 10 anos de Relações com Investidores, neste país. (...) A atividade nasceu pela necessidade ao cumprimento de formalidades legais. Entretanto, a falta de institucionalização dentro da empresa, tem sido quase total. Subordinada às mais diversas áreas na empresa, tais como Finanças, Administração, Presidência, entre outras, essa falta de 
padronização ainda marca a estrutura de RI no Brasil. (...) Se analisarmos as diversas posições hierárquicas que a área de RI tem ocupado nas empresas podemos relacionar: seções, assessorias, gerências, coordenadorias, superintendências e, é claro, diretorias, não exclusivas. (...) Mas o maior problema que a estrutura de RI enfrentou nesta primeira década foi a distância do poder, da informação estratégica. Esta distância significa falta de credibilidade externa (mercado) e, sobretudo, interna (em todas as áreas da empresa). (MARQUES, 1999, p.12).

\subsection{Fundamentos de um programa de Relações com Investidores}

Ao se observar as áreas de Relações com Investidores de diversas empresas, destacam-se as similaridades presentes em diversas atividades e formas de divulgação de informações. Porém, antes de sua implementação, um programa de relações com investidores deve partir de uma prospecção intitulada pesquisa referencial, a qual tem como objetivo "verificar, por um lado, o quanto o mercado sabe sobre a empresa e, por outro, qual o grau de distorção e preconceito existente entre os investidores e suas principais influências." (MAHONEY, 1997, p.37). Essa prospecção é similar ao conceito de "auditoria de opinião" em Relações Públicas, apresentado no item 3.1 desta seção.

Considerando como grupos fundamentais os profissionais de investimento, investidores institucionais e corretores, a amostragem deveria abranger, dentre estes grupos, as pessoas com interesses na empresa e, também, as sem interesse, para obter suas impressões. Assim como devem ser entrevistados os investidores individuais que a empresa possua. Este princípio está alinhado com a comunicação empresarial de Relações Públicas:

Basta adotar o princípio da segmentação, classificando os públicos por nível de interesses em comum, estabelecer para cada um deles uma linguagem e abordagem específicas, respeitando suas características. Em todas estas situações o objetivo principal é conhecer as necessidades e expectativas de cada público e, a partir de então, criar as condições ideais para harmonizar os interesses envolvidos. (SHMIDT, 2001, p. 173). 
Uma vez descritos os públicos, são utilizadas formas de comunicação dirigida, pois:

À comunicação dirigida cabe a elaboração da mensagem eficiente, eficaz e apta a produzir os efeitos desejados no público receptor. (FERREIRA, 2001, p. 73)

Este composto de Teoria de Comunicação, vinda de Relações Públicas, com a adição de conceitos e terminologia contábeis, forma a base dos serviços informacionais de Relações com investidores.

\subsubsection{Objetivos para um programa de Relações com Investidores}

Após a pesquisa referencial, idealmente devem ser definidos os objetivos gerais e específicos do programa. Além da idéia de "atender às necessidades de informação dos interessados na empresa", um programa com objetivos bem delineados ajuda a definir outros elementos. Por exemplo, as pessoas que vão trabalhar ali e os custos envolvidos, ou seja: "uma análise frontal das qualificações necessárias pela equipe de profissionais, grau exigido de participação gerencial, projeções de custos razoáveis e estimativa realista de resultados. " (MAHONEY, 1997, p.35).

Esta formalização exige um comprometimento da administração da empresa e dos executivos envolvidos nos processos de geração de informação suporte para a área. Um dos problemas que se busca evitar é a inconsistência da comunicação, ou seja, quando as empresas são "demasiadamente promocionais falando profusamente quando têm alguma coisa a dizer, e se fechando quando as coisas não vão muito bem. As administrações empresariais devem enfrentar esse problema antes de se lançarem num programa intensivo de comunicação com investidores. " (MAHONEY, 1997, p.36).

O programa de Relações com investidores, portanto, deve estar embasado nos fundamentos da Comunicação, como descrito abaixo. 
estratégia da abordagem, a mensagem em si, e que busquemos os canais para transmiti-la. Hoje, o sucesso estará com as empresas que buscarão uma interação com seus públicos, medindo o entendimento e a aceitação de suas atitudes passo a passo. Para isto e por isto esta postura moderna de abertura de canais facilitadores e dinamizadores do feedback.

A compreensão das demandas, expectativas e necessidades nos vários níveis sociais dos seus públicos valorizou a segmentação, 0 tipo de abordagem e a linguagem utilizada, desembocando na necessidade de uma verdadeira interação com os mesmos, que vem sendo apontada pelos técnicos em gestão como um dos ingredientes de sucesso e permanência da empresa. (GIANGRANDE, 2001, p. 190)

\subsubsection{Geração e uso da informação}

Para elaborar o conteúdo a ser apresentado aos investidores, os profissionais de relações com investidores devem conhecer quais informações são importantes para a análise de investimentos de forma geral, assim como as de caráter mais específico do negócio e também deve conhecer a empresa bem o suficiente para ser questionado pelos usuários. Por isso, são gerados dois tipos principais de informação:

a factual, informações expressas em números (quantitativa), que os analistas e investidores precisam para montar o seu acervo de dados, efetuar suas análises e tomar suas decisões de investimento baseadas em fórmulas ou julgamento; e os insumos qualitativos, que habilitam os analistas e investidores a dar maior peso e significado a tais números em suas recomendações. (MAHONEY, 1997, p.42).

Existe a informação apontada pela revista RI como básica, que virtualmente todo analista, corretor ou investidor deseja saber. Ela serve como uma plataforma. Essencialmente, essa informação compreende:

1) Receitas, apresentadas por linhas de produtos ou principais serviços, se elas crescerão ou não, e quais novas fontes de receitas serão desenvolvidas no futuro;

2) Despesas, mostradas por tipo, se aumentarão ou diminuirão, e os programas para reduzi-las; 
3) Lucros, especificamente o valor derivado das operações e dos controles financeiros, e as oportunidades para aumentá-los no futuro;

4) Dispêndios de Capital e como os recursos serão utilizados para elevar as receitas ou reduzir os custos;

5) Gastos em pesquisa e desenvolvimento de produtos;

6) Custos de fabricação, e como a empresa está trabalhando para ser mais eficiente em custos;

7) Produtividade por empregado e programas para melhorá-la;

8) Planos e programas Estratégicos para crescer no futuro;

9) Taxa de retorno sobre os ativos, para determinar a eficiência das operações;

10) Níveis de Fluxo de Caixa, e como os recursos estão sendo aplicados, no reinvestimento em projetos de crescimento ou distribuídos para os acionistas na forma de dividendos ou recompra de ações; e

11) Incentivos aos administradores e empregados para levá-los a trabalhar mais e com maior eficiência. (Teoria \& prática. RI nº 28 de 06/00 p.17)

Além da fonte principal - as informações contábeis, todas as áreas de negócios da empresa são consideradas na elaboração da informação a ser divulgada. Isso reúne o planejamento estratégico, os novos projetos, as divisões, a logística etc. Essa composição editorial possui uma base de comunicação: a avaliação da empresa, conforme Mahoney (1997, p.43): "como os investidores procuram atribuir um valor para as ações de uma empresa, tanto a sua administração como os seus profissionais de relações com investidores estão, atualmente, se concentrando nos ingredientes vitais da avaliação."

Quanto ao principal grupo de usuários, os profissionais de investimento, eles podem ser classificados em dois grupos, de acordo com seu trabalho: analistas "sell side", os quais trabalham com informações para a venda de ações e os "buy side", que emitem seus pareceres em análises de compra de ações. Esta segmentação é considerada muito importante para os serviços informacionais de Relações com investidores, pois são os usuários mais tecnicamente capacitados e com interesses de busca específicos. 
Ir diretamente ao "buy side" (lado da compra) está se tornando uma importante segunda dimensão do processo de relações com investidores. O fundamento é uma sólida cobertura de analistas do "sell side" (lado da venda) ou seja, ter várias corretoras e bancos respeitados no mercado escrevendo sobre a empresa e, espera-se, fazendo recomendações de compra. (Teoria \& prática, $R I n^{\circ} .5$, p.7, julho, 1998).

O trecho acima mostra que até o direcionamento da comunicação recebe influência desses profissionais.

\subsubsection{Divulgação e tecnologia}

As empresas de capital aberto devem, por exigência legal, dispor as informações ao mesmo tempo para todos os seus interessados. Essa medida visa coibir a divulgação de informações privilegiadas que favoreceriam alguns negociadores, conforme item 2.5.1.

Entretanto, as companhias abertas têm buscado desenvolver formas de atingir públicos com conhecimentos técnicos diferenciados.

A forma de comunicar e os métodos de distribuição de informações devem convir aos usuários destinatários e serem feitos de modo mais eficaz, segundo Mahoney (1997). As formas de divulgação mais comuns para as companhias abertas são:

- Demonstrações e relatórios obrigatórios para órgãos de governo, como o conjunto de Demonstrações Contábeis, que são enviados para o governo, as entidades reguladoras e publicados em jornais;

- Divulgação eletrônica de informações, meio de maior expansão, destacando-se o vasto conteúdo dos websites e suas possibilidades de transferência de arquivos, vídeo conferências, conference call, telefone e email, entre outros;

- Apresentações da empresa para a comunidade de investimentos, palestras e eventos; e

- Malas-diretas, publicações enviadas a usuários cadastrados. 
Técnicas e tecnologias em favor da exposição da empresa, alinhados com sua imagem institucional almejada, pode ser considerado um axioma do programa de Relações com investidores. Dele partem as diversas formas e as inovações de contato com usuários.

Existem inúmeros veículos de comunicação para atingir o mercado com um todo. O mais importante é um ativo programa de relações com a mídia, objetivando uma presença freqüente nos jornais, revistas e programas de televisão lidos e vistos pelos investidores. Em seguida, deve-se fazer a mais ampla distribuição possível do relatório anual da empresa. Além dos acionistas, eles devem ser enviados para os analistas dos bancos e corretoras, etc (...)Teoria \& prática $R I n^{\circ} .5$ de julho/98 p.7

Porém, segundo Mahoney (1997), os analistas e investidores interessados buscam discussões individuais. Neste contexto, a apresentação da empresa em reuniões alcança a maior relevância, sendo passível de julgamento tanto a administração da empresa como a área de relações com investidores. Tornam-se evidentes a capacidade de organização e disposição das informações, a profundidade do conhecimento sobre a empresa e seu setor, o domínio da influência de fatores macroeconômicos e a própria acessibilidade da empresa para fornecer mais informações.

As apresentações e a internet são tratadas em diversos artigos da revista RI, do Instituto Brasileiro de Relações com Investidores (IBRI), conforme trecho a seguir:

Uma outra forma para atingir amplamente o mercado é através de apresentações a grupos de investimentos, tais como conferências patrocinadas por bancos ou corretoras, reuniões em associações de analistas ou corretoras, e encontros realizados pela própria empresa. Atualmente, a forma mais ampla para atingir o mercado é através de Internet. Milhões de investidores individuais usam diariamente a Internet para obter informações. (...)

Com a base das comunicações que cobrem o mercado, as empresas podem se concentrar na identificação das instituições mais prováveis a se interessarem por suas ações. (...) Existem serviços disponíveis para o fornecimento desses dados. (...) Suas informações são extremamente úteis pra empresas com programas de ADRs. Antes mesmo de fazer qualquer viagem para a realização de road shows, pode-se determinar as instituições que deverão ser convidadas, selecionando aquelas mais prováveis de ter maior interesse pela 
empresa. Esses fornecedores de dados já estão trabalhando para cobrir os investidores institucionais numa escala global. (Teoria \& prática, $R I n^{\circ} 5$, p.8, julho, 1998).

Este mesmo instituto realizou um estudo com diversas empresas, denominado $2^{\mathrm{a}}$ Enquete IBRI - "Ações de Comunicações", o qual apresentou, em $1^{\circ}$ de setembro de 2004, os seguintes apontamentos:

\section{1) As ferramentas mais importantes para a comunicação do RI:}

O gráfico das ferramentas aponta o website como o principal meio de comunicação para a área de relações com investidores, seguido por uma apresentação sucinta dos relatórios contábeis, denominada press release. As formas de contato diretas como apresentações e reuniões têm quase a metade da importância dada ao website.

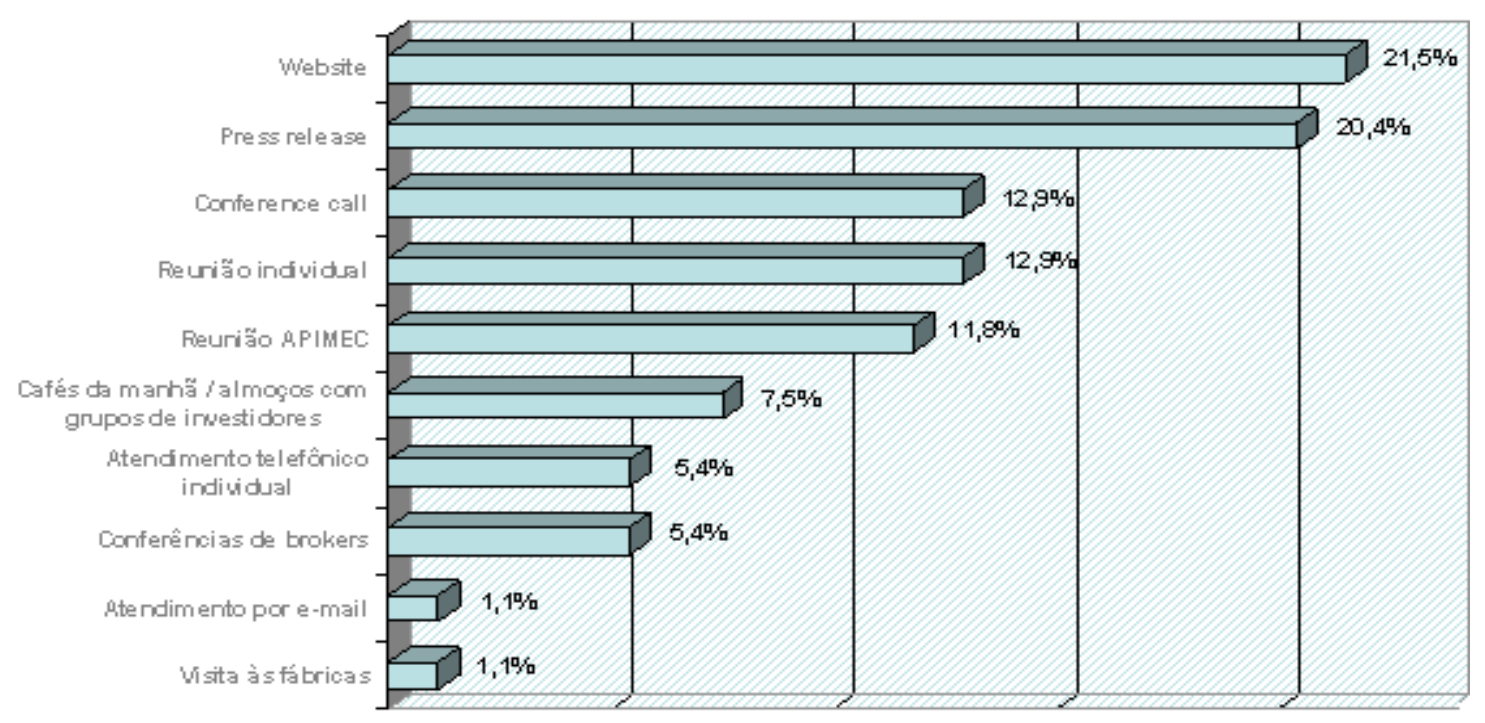

\section{2) A freqüência ideal de comunicação com cada analista}

As empresas entrevistadas obtiveram de seus usuários a informação de que a freqüência de 4 a 8 contatos anuais é a média mais adequada de fornecimento e mediação de suas divulgações. 


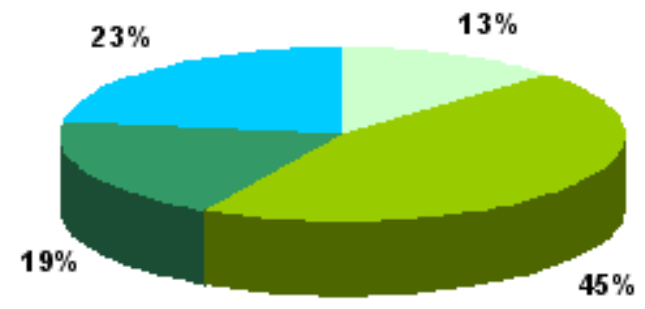

\author{
até 4 por ano \\ de 4 a 8 por ano \\ - de 9 a 11 por ano \\ mais de uma vez por mês
}

\title{
3) Os locais de preferência para reuniões com analistas
}

A metade das empresas consultadas prefere realizar as reuniões no país, embora um grande número já prefira nos Estados Unidos, cerca de um terço delas.

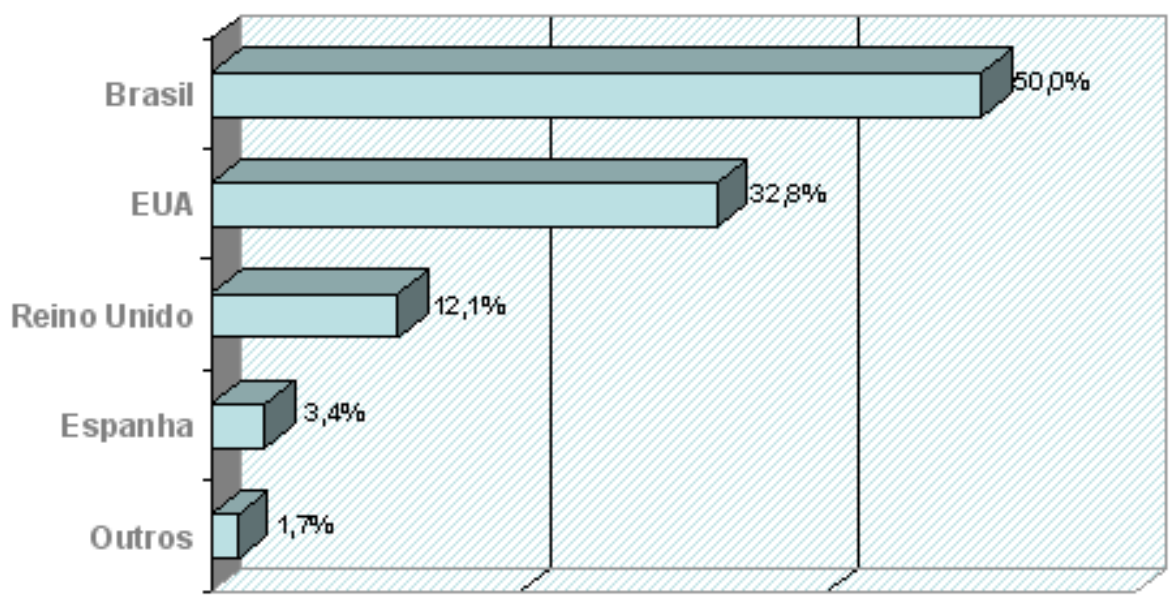

Outros $=$ Analistas, Corretoras, Investidores institucionais e NYSE.

\section{4) Entidades de preferência para realizar as reuniões}

Essas reuniões de apresentação de resultados e outras informações sobre a empresa podem ser realizadas em diversos locais para reunir profissionais de investimentos principalmente. Os locais apontados como mais adequados foram os próprios bancos de investimentos, em primeiro lugar, e a Associação dos Analistas e Profissionais de Investimento do Mercado de Capitais (APIMEC). Os demais locais apontados são de pequena participação. 


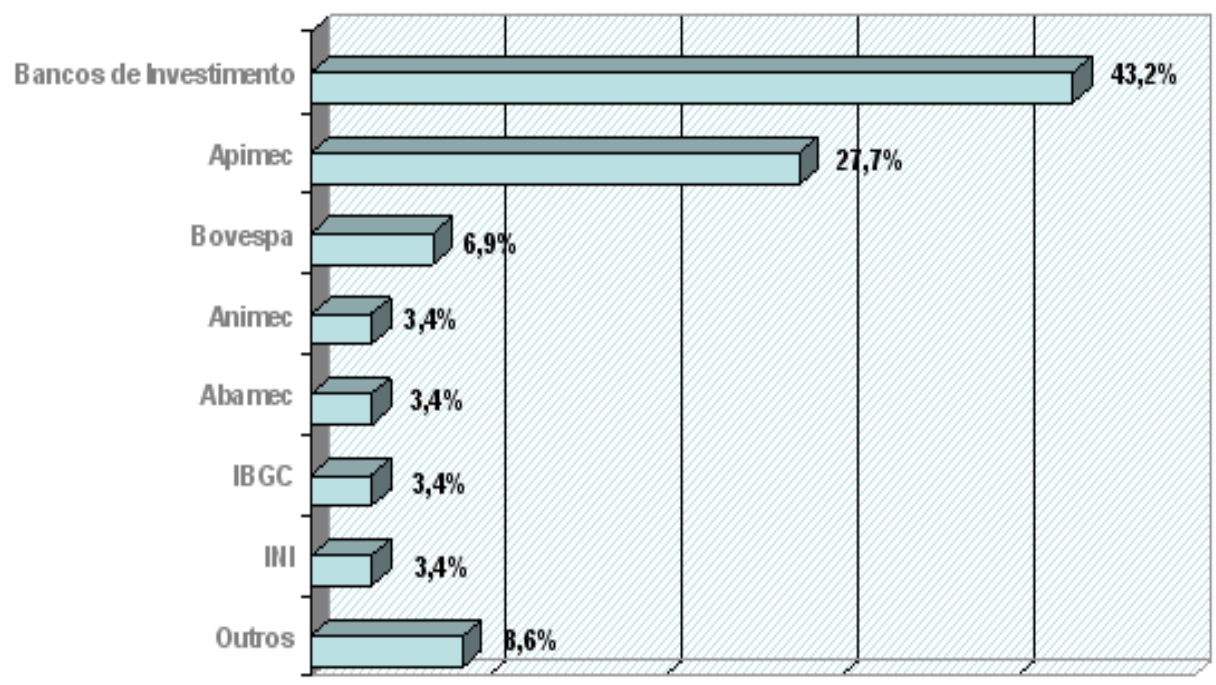

Outros = Analistas, Corretoras, Investidores institucionais e NYSE

5) 0 valor investido nestas reuniões por ano (passagem aérea, hotel, material, etc.)

As reuniões são eventos de informação e mediação com gastos relevantes que denotam a importância de sua realização para as companhias abertas.

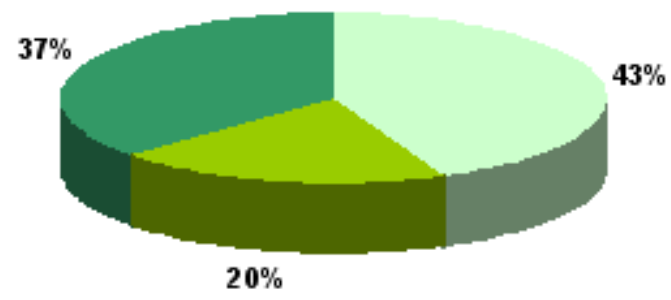

até $R \$ 100$ mil

\# de $\mathbf{R} \$ 100$ mil até $\mathbf{R} \$ 200 \mathrm{mil}$

- mais de $\mathbf{R} \$ 200$ mil

6) O orçamento para a área de RI, para 2004, excluídas as despesas administrativas

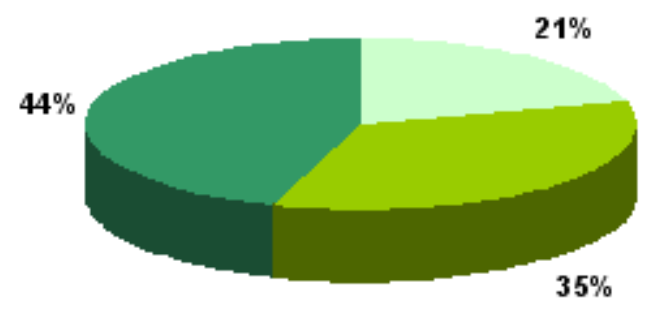

até $\mathbf{R} \$ 500 \mathrm{mil}$

de $\mathbf{R} \$ 500$ mil até $\mathbf{R} \$ 1$ milhão

mais de $\mathbf{R} \$ 1$ milhão 
Os recursos investidos são volumosos e os gráficos dos itens 6 e 7 mostram que estão em expansão, especialmente motivados pelo aumento da realização de reuniões.

\section{7) Este orçamento difere de anos anteriores? Se sim, os motivos são}

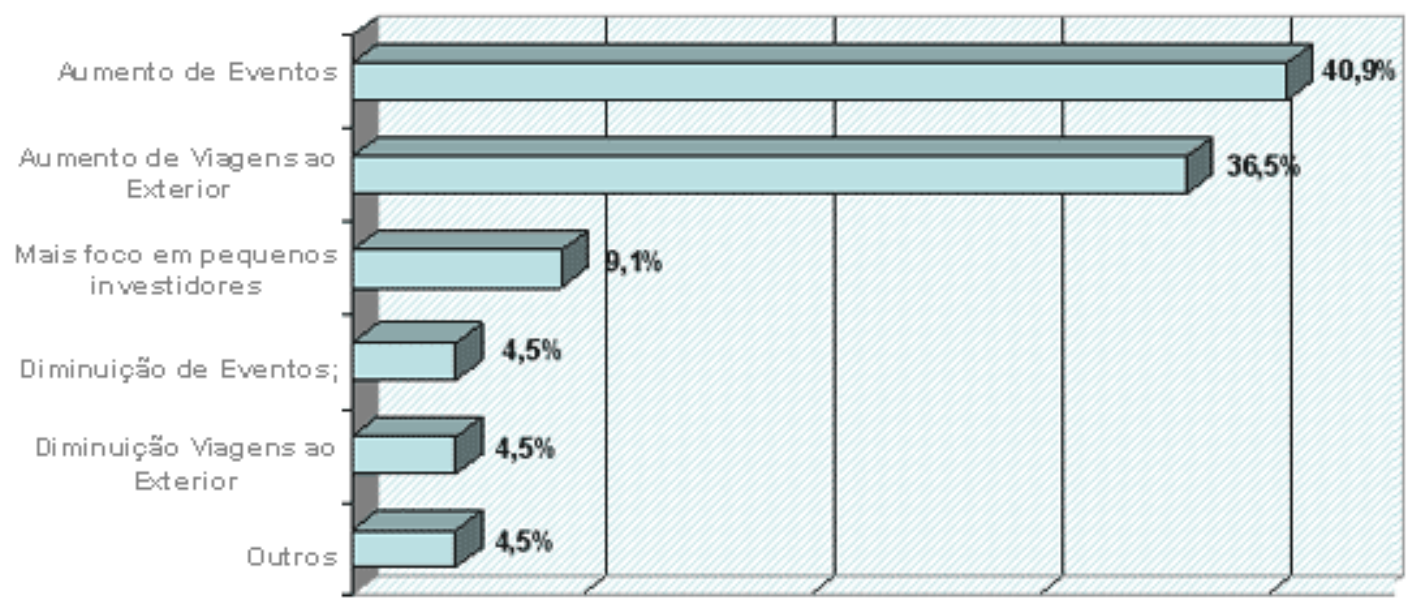

Outros = Adaptação à Sarbanes Oxley, e Redução da liquidez do papel.

\section{8) Existe alguma comunicação voltada especialmente para investidores individuais? Quais?}

O atendimento, ou a mediação, dedicada a investidores individuais é um tema recente para as áreas de relações com investidores. O gráfico a seguir mostra que a maioria das empresas não respondeu a esta questão.

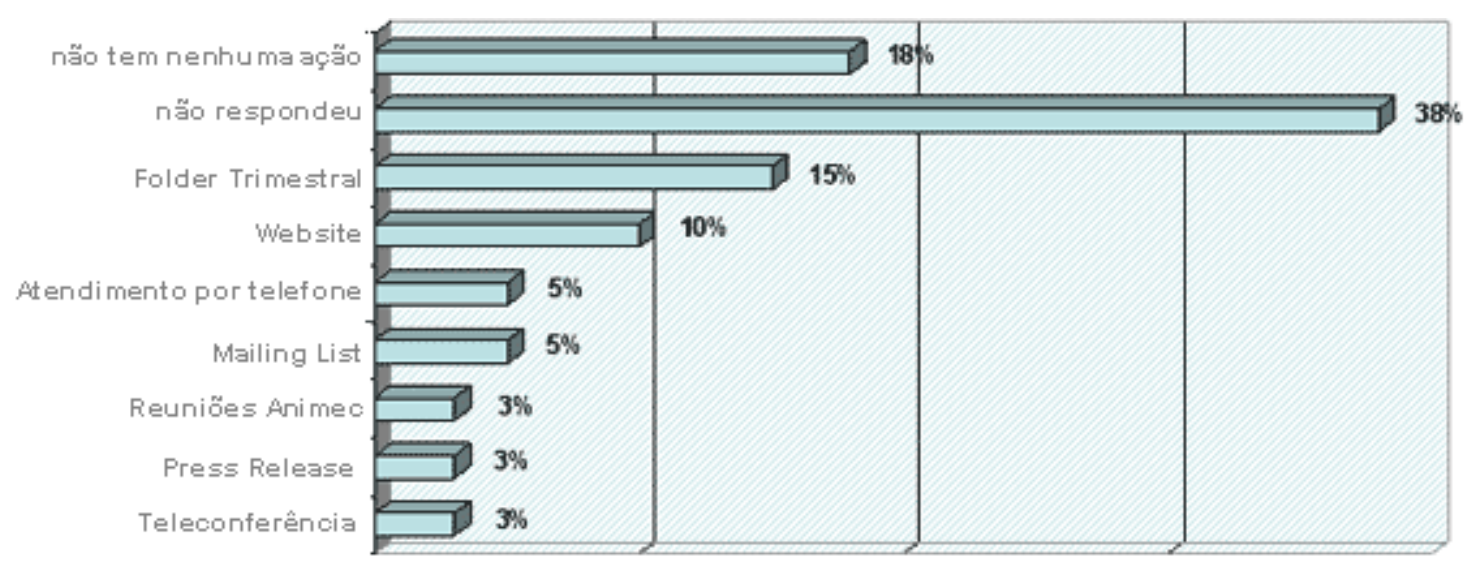


Os resultados da pesquisa supra constituem a caracterização da área de relações com investidores no país e a identificação de formas e tendências desse trabalho nas companhias abertas.

\subsection{O enfoque da Valorização}

A idéia de criar "valor para o investidor" começou a ser enfocada nos Estados Unidos da década de 80 e, desde então, só aumentou sua importância para as companhias abertas, em todo o mundo. A valorização pode ser entendida como "o processo fundamental utilizado pelos investidores na determinação do valor de uma empresa, para decidir se a mesma representa um bom investimento ao seu preço atual." (MAHONEY, 1997, p.198).

Outro aspecto da valorização é aquele que

envolve o processo de incremento do valor - as medidas da empresa que geram maiores retornos, aferidos pelos modelos dos investidores em função do aumento dos lucros, fluxos de caixa e valor patrimonial. $O$ incremento do valor é conseguido mediante o uso produtivo dos ativos existentes e de novos investimentos que geram retornos acima dos seus respectivos custos. (MAHONEY, 1997, p.198)

Para o mesmo autor (1997, p.197), "as administrações estão aprendendo como os investidores calculam o valor e estão desenvolvendo atividades específicas, mostradas em estudos de pesquisas, para elevar o valor mediante a conquista da preferência dos investidores".

As Relações com Investidores representam o processo de valorização em quatro elementos principais e interligados que são:

1. Compreender como a comunidade de investimentos determina a valorização da empresa;

2. Transmitir o que, no entendimento da empresa, deva ser a base da sua valorização;

3. Corrigir quaisquer visões distorcidas que o investidor porventura tenha da empresa e de suas principais componentes de valorização; e

4. Comunicar todas as notícias importantes que venham afetar a valorização. (MAHONEY, 1997, p.1997) 
A crítica que se faz a este enfoque tem como base o perigo de a empresa privilegiar ações que favoreçam um aumento de valor instantâneo em detrimento de ações que tragam benefícios duradouros. Entretanto, os métodos de se calcular o valor de uma empresa, ou quanto vale sua ação, mais recomendados por consultores e especialistas sempre incluem horizontes de longo prazo.

As empresas não deixam de ter uma certa medida de controle sobre a melhoria do seu retorno sobre investimentos e no condicionamento do seu crescimento a longo prazo através de iniciativas tecnológicas, conquista de fatias do mercado, produção a baixo custo, práticas inteligentes de marketing e investimentos no futuro, que acabam alcançando retornos superiores ao custo de capital. Podem também se desfazer de ativos de fraco desempenho como um meio de aumentar o valor. (MAHONEY, 1997, p.203)

\subsection{As informações relevantes}

Para a Teoria da Contabilidade, informações relevantes são aquelas definidas conforme a Comissão de Valores Mobiliários (CVM), em sua Instrução Normativa $\mathrm{n}^{\circ} 358$ de 2002:

\footnotetext{
Art. 20 Considera-se relevante, para os efeitos desta Instrução, qualquer decisão de acionista controlador, deliberação da assembléia geral ou dos órgãos de administração da companhia aberta, ou qualquer outro ato ou fato de caráter político-administrativo, técnico, negocial ou econômico-financeiro ocorrido ou relacionado aos seus negócios que possa influir de modo ponderável:

I - na cotação dos valores mobiliários de emissão da companhia aberta ou a eles referenciados;

II - na decisão dos investidores de comprar, vender ou manter aqueles valores mobiliários;

III - na decisão dos investidores de exercer quaisquer direitos inerentes à condição de titular de valores mobiliários emitidos pela companhia ou a eles referenciados.
}

Outra definição similar é a estabelecida pela Securities and Exchange Commission (SEC) americana, a qual considera como "informação relevante" aquela 
capaz de influenciar um investidor a tomar uma decisão de comprar, vender ou manter um investimento.

Sendo assim, a revelação e a não revelação de uma informação importante estão igualmente contidas na relevância. Neste conceito está a raiz de a divulgação ser obrigatoriamente simultânea e democrática. A revelação de informações, seletivamente, é proibida, pois viabiliza vantagens entre investidores.

Os problemas sobre o que é relevante surgem em sua maioria em situações envolvendo fusões, aquisições, tomadas de controle e em vantagem em termos de informação. Os agentes de relações com investidores precisam estar permanentemente cônscios da possibilidade de serem envolvidos numa discussão em torno de informação relevante. (MAHONEY, 1997, p. 446).

Grande parte das empresas discute o equilíbrio entre serem agressivas ou defensivas, abertas ou cautelosas, quando consideram a questão da divulgação de informações. O traço comum nos primórdios das atividades de relações com investidores era a tendência das empresas em serem muito prolixas nos momentos de crescimento de lucros e expansão e serem muito reservadas nas crises e recessões. Esta inconstância ou falta de uniformidade de procedimentos gerou críticas e mudanças:

Políticas e procedimentos claramente enunciados e compreendidos fazem funcionar um programa de revelações. Políticas $e$ procedimentos estão interligados. Estes últimos preenchem os primeiros. Os princípios básicos das políticas devem ser escritos... (MAHONEY, 1997, p.461).

O mesmo autor publica um conjunto de parâmetros a serem considerados na elaboração das políticas e procedimentos. Entre os tópicos estão: a adoção de uma abordagem de equipe para as divulgações da empresa; o estabelecimento de controle interno incluindo comunicados, discursos, apresentações, declarações etc; a preservação da confidencialidade minimizando o número de pessoas "que precisam ter conhecimento e prepará-las para a importância do sigilo"; a centralização de material de informação relevante para o controle da disponibilidade; a educação interna a respeito dos procedimentos de divulgação da empresa e o conhecimento 
desses procedimentos também por parte do mercado de capitais; acompanhamento da cobertura feita pela mídia ou mercado sobre os comunicados e declarações; a realização de reuniões prévias com os executivos que falarão ao mercado, entre outros. Conforme matéria da revista RI:

\begin{abstract}
Apenas poucas pessoas devem falar em nome da empresa. Deve ser designado um porta-voz para cada público importante. $O$ executivo de RI fala com os analistas e investidores, o executivo de comunicação corporativa fala com a mídia. Podem ser designados porta-vozes para os empregados, clientes, e autoridades governamentais. Em situações de crises altamente críticas o CEO deve ser o principal porta-voz. (...) É fundamental que cada portavoz forneça essencialmente a mesma informação. As respostas às perguntas devem se limitar ao teor da informação acordada por todos." (Teoria \& prática. RI $n^{\circ} 37$, p. 9, março, 2001).
\end{abstract}

A função RI - relações com investidores - mostra, conforme relatado nesta seção, amadurecimento como prestador de serviços informacionais e fundamentação conceitual de área de especialidade. Essa junção de habilidades veio a preencher a lacuna entre a comunicação técnica da contabilidade e a comunicação generalista de relações públicas, por meio da introdução da mediação de informações contábeis realizada por executivos com muito conhecimento técnico. 


\section{Seção 4: Apresentação da pesquisa de campo}

\subsection{Metodologia}

Este trabalho realiza-se no campo da Ciência da Informação e pode ser classificado como uma pesquisa qualitativa histórica-estrutural, em consonância com as seguintes características apresentadas por Triviños (1987):

A investigação histórico-estrutural aprecia o desenvolvimento do fenômeno não só em sua visão atual que marca apenas o início da análise, como também penetra em sua estrutura (...) para descobrir suas relações e avançar no conhecimento de seus aspectos evolutivos, tratando de identificar as forças decisivas responsáveis por seu desenrolar característico.

(...) parte também da descrição que intenta captar não só a aparência do fenômeno, como também sua essência. Busca, porém, as causas da existência dele, procurando explicar sua origem, suas relações, suas mudanças e se esforça por intuir as conseqüências que terão para a vida humana. (TRIVINOS, 1987, p.129).

O fenômeno é a mediação de informações em linguagem de especialidade, neste caso, a linguagem contábil. O que se busca provar é sua necessidade para que a Contabilidade possa atingir sua função comunicativa.

Para tanto, propõe-se, além dos levantamentos das teorias em Ciência da Informação e Ciências Contábeis, uma pesquisa de campo. O componente experimental dessa pesquisa é um estudo de casos múltiplos. Um estudo de caso é uma investigação específica que se aplica a um fenômeno contemporâneo dentro de seu contexto da vida real, especialmente quando os limites entre o fenômeno e o contexto não estão claramente definidos, segundo Yin (2001).

O Estudo de Caso possui uma vantagem distinta quando são feitas questões de pesquisa do tipo "como" ou "por que" sobre um conjunto contemporâneo de acontecimentos sobre o qual o pesquisador tem pouco ou nenhum controle. Sua investigação enfrenta uma situação tecnicamente única em que haverá muito mais variáveis de interesse do que pontos de dados, e, como resultado, baseia-se em várias fontes de evidências. Além disso, beneficia-se do 
desenvolvimento prévio de proposições teóricas para conduzir a coleta e a análise de dados, conforme Yin (2001).

Quanto ao modelo teórico da Comunicação que mais abrange o tema desta pesquisa, tem-se o Modelo Teórico Recepcional, que estuda a formação do sentido de uma mensagem tendo como base a interação continuada dos elementos que a constituem:

A produção de sentidos é intrínseca ao processo da Comunicação, observando-se que o sentido de uma mensagem se constitui pela 'direção significativa' que a ela é dada. Em estado puro, tal sentido não residirá na codificação feita pelo emissor; não estará no meio de comunicação escolhido; tampouco será encontrado no procedimento de decodificação que o receptor realiza. O sentido de uma mensagem repousará na interação continuada desses fatores.... (POLISTCHUK e TRINTA, 2003, p.151).

Em outro trecho,

Recepção supõe, portanto, uma modalidade de interação entre pólos de produção e o de consumo, que irá determinar a constituição de um sentido por parte do leitor/espectador/ouvinte. (POLISTCHUK e TRINTA, 2003, p.153).

Sob as referencias bibliográficas citadas será analisada a mediação institucional efetuada pelas empresas selecionadas, tendo como base primordial os produtos comunicacionais divulgados, os canais utilizados e as respostas às entrevistas.

A pesquisa de campo consiste de entrevista semi-estruturada com um executivo que responda pelo serviço de informações de cada empresa selecionada. Conforme Triviños:

Podemos entender por entrevista semi-estruturada, em geral, aquela que parte de certos questionamentos básicos, apoiados em teorias e hipóteses, que interessam à pesquisa, e que, em seguida, oferecem amplo campo de interrogativas, fruto de novas hipóteses que vão surgindo à medida que se recebem as respostas do informante. Desta maneira, o informante, seguindo espontaneamente a linha de seu pensamento e de suas experiências dentro do foco principal colocado pelo investigador, começa a participar na elaboração do conteúdo da pesquisa. (TRIVINOS, 1987, p. 146). 
Este usuário interno das informações contábeis é quem desenvolve toda a mediação institucional da empresa, ou seja, ele elabora o serviço de informação explicativa e interativa com o mercado (em seus diversos segmentos).

\subsubsection{Os critérios de seleção das empresas entrevistadas}

Um dos maiores especialistas mundiais em websites de Relações com Investidores, com mais ampla participação de empresas e países, é o IR Global Rankings, com sede nos Estados Unidos. O prêmio "Top Five" de 2005 contou com 426 participantes (websites) de 42 países. Este prêmio é concedido aos cinco melhores websites sobre Relações com Investidores, com base em critérios técnicos e é dividido por regiões mundiais, por países e também por setores industriais.

No Brasil, este prêmio é editado pela MZ Consulting e o resultado de 2005, cujas empresas premiadas constituem o estudo de casos desta pesquisa, foram:

TOP 5 - MZ consulting

$\begin{array}{ll}\text { Empresa } & \text { Pontos } \\ \text { Petrobras } & 73.5 \\ \text { Unibanco } & 68.5 \\ \text { Banco Itaú } & 67.0 \\ \text { Banco Bradesco } & 66.5 \\ \text { Ultrapar } & 65.0\end{array}$

\subsubsection{Processo eletivo de Websites de Relações com Investidores}

Constituindo os critérios técnicos do agente premiador, seis atributos são identificados como sendo os mais importantes para que um website de Relações com Investidores torne-se um instrumento de consulta e comunicação para acionistas, potenciais investidores, analistas e demais agentes do mercado de capitais, aos quais está primordialmente dirigido. 


\section{a) Conteúdo e profundidade das informações financeiras (40 pontos)}

Um bom conteúdo na Internet é caracterizado, segundo os premiadores, pela sua amplitude (quantidade de informação corporativa e financeira recente) e profundidade (quanto de histórico). Uma vez que a capacidade de armazenamento de informações online é muito vasta, a versão eletrônica de comunicados, anúncios de dividendos e relatórios deve ser mais completa que a versão impressa.

\section{b) Tecnologia e navegabilidade (15 pontos)}

Para os organizadores, um website de RI bem projetado combina tecnologia: webcasts (vídeo e áudio, ao vivo e arquivo) e recursos de multimídia. 0 resultado é uma fácil navegabilidade.

Como a tecnologia subjacente continua se aperfeiçoando (ferramentas de procura, bancos de dados interativos e modelagem de gráficos), deve-se permitir que os investidores façam suas próprias análises (cálculo do retorno sobre o investimento, geração de gráficos que mostram tendências em resultados operacionais e outras relações financeiras).

\section{c) Interatividade com o visitante (15 pontos)}

Os websites são descritos pelos organizadores do prêmio como uma ferramenta de comunicação e não apenas mais uma fonte de informação. Características como e-mail de alerta de atualizações, perguntas \& respostas, voto online de Proxy e salas de discussão permitem ao visitante interagir mais intimamente com a companhia. 


\section{d) Qualidade do Design (15 pontos)}

O website de Relações com Investidores considerado bem projetado exibe, de forma coordenada, gráficos, textos e dados financeiros em uma história coerente. A seção de RI deve estar visível na página inicial do website da empresa.

\section{e) Tempestividade na disseminação de informações relevantes (10 pontos)}

A disseminação de informações via Internet leva segundos comparativamente aos minutos de um fax ou dias de uma correspondência normal, além de adicionalmente representar um custo bastante inferior. Conseqüentemente, informações financeiras online devem ser bem mais responsivas do que aquelas disponibilizadas através de canais convencionais. O foco está nas informações em tempo real, consideradas quase como uma evidenciação contínua da empresa.

\section{f) Flexibilidade de idioma e moeda (5 pontos)}

Os websites estão tornando-se cada vez mais flexíveis e adaptando-se crescentemente aos interesses dos visitantes. Para websites de Relações com Investidores, as duas características principais de flexibilidade são: moeda de apresentação dos resultados financeiros e idioma. Em alguns casos, isto significa apresentar as demonstrações contábeis em padrões contábeis internacionais também. Devem também permitir uma visualização personalizada, para que o usuário possa acessar somente a informação em que está interessado.

Ainda na visão das empresas que concedem os prêmios:

Os websites de RI são o melhor meio de comunicação com a comunidade de investimento. Os melhores websites de RI globais utilizam a força da Internet para informar os investidores sobre tudo 
o que eles possam querer saber sobre os negócios da companhia, seu desempenho financeiro, história, perspectivas, competição e cultura. Esses websites propiciam fácil acompanhamento da empresa através de eventos regulares transmitidos via Internet (webcasting), FAQs e e-mail. Para auxiliar investidores a encontrarem a informação desejada e novidades, eles também oferecem janelas de procura, alertas por e-mail e calendário de eventos futuros. Bons websites de RI não são apenas uma tela na frente do investidor, mas uma interface permeável de duas vias. Eles permitem que investidores: votem seus proxies; adquiram ações da companhia; participem de teleconferências trimestrais; e manipulem a informação online através de ferramentas analíticas, de personalização (linguagem e moeda) e de modelagem. (ZABISKY, 2000, p. 12-13).

Os critérios técnicos do agente premiador, quando comparados às características qualitativas das informações contábeis apresentam alguns fatores comuns. Os itens relacionados ao conteúdo e profundidade (a), interatividade (c) e flexibilidade de idioma e moeda (f) estão alinhados com as premissas da Compreensibilidade. A tempestividade (e) é exigência da característica qualitativa descrita como Relevância. Os itens de tecnologia (b) e flexibilidade (f) são componentes que viabilizam a Comparabilidade. Entretanto, os atributos da Confiabilidade não fazem parte dos critérios de premiação.

\subsubsection{O questionário para as Empresas}

As questões desta pesquisa referente ao estudo de casos múltiplos das cinco empresas selecionadas têm como ferramenta uma entrevista semi-estruturada, cujo questionário roteiro é apresentado a seguir. 
Pesquisadora: Ângela D.G. Amorim

UNIVERSIDADE DE SÃO PAULO - USP

ESCOLA DE COMUNICAÇÃO E ARTES - ECA

DOUTORADO EM CIÊNCIA DA INFORMAÇÃO

Tema da pesquisa: a mediação da informação contábil

Orientadora: Profa. Dra. Nair Y. Kobashi

\section{Identificação}

1. Nome, cargo, formação, breve histórico

2. equipe: tamanho, principais funções. Essas funções são compartilhadas? Ou há divisão de trabalhos, etapas, clientes etc?

3. Quem são os usuários das informações?

4. Como a instituição os identifica? Faz pesquisa própria? Utiliza dados de outras fontes? Quais?

5. Como são classificados (tipos de investidor)?

6. Tipos de informações: há produtos customizados? Mesmo com a democracia da divulgação, há explicações ou formas diferenciadas de mediação? A linguagem técnica é de conhecimento obrigatório?

\section{Processo de geração de informação}

7. Como ocorre o processo: análise diagnóstico da situação, planejamento, ação, feedback, mensuração (e reinício)? Quais as informações e formas de captação de informação de cada fase? Existe algum problema ou curiosidade em alguma fase?

8. Como é feito o armazenamento das informações? (organização para acesso e recuperação)

\section{Meios de divulgação}

9. Quais os canais que a instituição se utiliza? Site, Serviços terceirizados, jornais, Bovespa - CVM, (mais algum?)

10. Como ocorre a mediação?

11. Qual a ordem de preferência do usuário? Como é medida? O que o Sr. pensa da obrigação legal de publicação em jornais?

\section{Ruídos e Barreiras}

12. Quais as principais barreiras internas ao trabalho de RI? As soluções são padronizadas?

13. Quais os entraves de comunicação interna mais comuns?

14. Quais as barreiras de recuperação da informação?

\section{Acréscimo de valor}

15. Essa instituição mede o acréscimo de valor que o RI traz para ela na visão dos usuários? Há algum estudo?

16. A valorização financeira da empresa pode ser relacionada ao crescimento do programa do RI?

A primeira parte do questionário busca identificar a estrutura operacional da área de "Relações com Investidores" da empresa, os entrevistados e também uma primeira tipologia de usuários e as principais informações.

Em seguida focaliza-se o processo de geração da informação, em complementação às questões prévias, fazendo o percurso que a empresa se utiliza para montar seus produtos de mediação e a forma de armazenamento empregada. 
Os meios de divulgação e os serviços que a empresa realiza ou contrata compõem os instrumentos de mediação, possibilitando uma primeira análise descritiva desse processo em cada caso estudado.

Os ruídos e as barreiras completam o descritivo da construção desse processo comunicacional. Para Kunsch (2002, p. 74) "Barreiras são os problemas que interferem na comunicação e a dificultam."

Por se tratar de companhias abertas, a última parte do questionário objetiva fazer uma relação entre a importância do processo de comunicação e mediação com reflexos em valorização econômica.

\subsubsection{Validação da recepção}

Na observação do fenômeno do crescimento dos serviços informacionais prestados pelas companhias abertas, esta pesquisa questiona como melhorar a compreensão dos usuários na transferência de informações contábil-financeiras e também o porquê deste crescimento. Para testar as hipóteses relacionadas a tais questões, propõe o estudo de casos múltiplos inicialmente descrito.

Ainda que os itens constantes do formulário de entrevistas com as empresas não apresentem pontos de constrangimento na relação empregatícia, o quadro a seguir foi elaborado no mesmo roteiro da entrevista, para definir pontos sensíveis ou de difícil verificação. Dito de outro modo, uma vez que as entrevistas foram realizadas com executivos das empresas estudadas, alguns temas constantes do formulário de entrevistas também foram objeto de questionamento para um público externo às mesmas. Dentre esses temas, destacam-se a questão sobre ruídos e barreiras que possam afetar a elaboração da informação a ser divulgada e a questão sobre o aumento de valor para a empresa resultante do serviço informacional prestado. 
Esses temas estão detalhados no quadro:

\begin{tabular}{|l|l|}
\hline \multicolumn{1}{|c|}{ Item pesquisado } & \multicolumn{1}{|c|}{ Verificabilidade } \\
\hline Identificação da equipe & Dados públicos, presentes no website. \\
\hline $\begin{array}{l}\text { Processo de geração de } \\
\text { informação }\end{array}$ & Não há. Porém o processo é metódico e não-confidencial. \\
\hline Meios de divulgação & $\begin{array}{l}\text { Os meios são consultáveis e os produtos de jornalismo } \\
\text { empresarial foram exibidos nas entrevistas. }\end{array}$ \\
\hline Ruídos e barreiras & $\begin{array}{l}\text { Ponto sensível: o entrevistado é questionado sobre problemas } \\
\text { e falhas. Alterações mais aparentes quando a empresa } \\
\text { começa a ter insucesso financeiro. Este item foi tema para o } \\
\text { grupo de controle. }\end{array}$ \\
\hline Acréscimo de valor & $\begin{array}{l}\text { Difícil verificação: as empresas não tinham método de } \\
\text { mensuração para esta questão. Este item foi tema para o } \\
\text { grupo de controle. }\end{array}$ \\
\hline
\end{tabular}

Uma vez que as entrevistas semi-estruturadas foram realizadas com as empresas (emissoras da comunicação), alguns especialistas em mercado de capitais foram ouvidos, como grupo de controle, contrabalançando as entrevistas. Este grupo, citado na tabela, teve a finalidade de complementar, qualitativamente, as respostas dos executivos, uma vez que seus componentes não têm ligação com as empresas estudadas, tampouco conhecimento de quais executivos fizeram parte das entrevistas.

O formulário, apresentado a seguir, foi respondido por alunos do curso de MBA em Finanças, Comunicação e Relações com investidores da Fundação Instituto de Pesquisas Contábeis, Atuariais e Financeiras (FIPECAFI) em convênio com o Instituto Brasileiro de Relações com investidores (IBRI), os quais são usuários de websites de relações com investidores, com grande conhecimento da área. 


\section{UNIVERSIDADE DE SÃO PAULO - USP \\ ESCOLA DE COMUNICAÇÃO E ARTES - ECA \\ DOUTORADO EM CIÊNCIA DA INFORMAÇÃO}

Tema da pesquisa: a mediação da informação contábil

Pesquisadora: Ângela D.G. Amorim

Orientadora: Profa. Dra. Nair Y. Kobashi

1) Dentre as características abaixo, marque a mais importante para um website de Relações com investidores ser considerado bom:

( ) conteúdo e profundidade das informações

( ) tecnologia e navegabilidade

( ) interatividade com o usuário

( ) rapidez na divulgação de informações relevantes

2) Quando uma Cia. aberta começa a ter insucesso financeiro, o que muda no serviço de relações com investidores?

( ) a empresa não atende com a assiduidade de sempre

( ) diminui as apresentações à comunidade de investimento

( ) marca entrevistas coletivas para dar explicações

( ) altera o website reduzindo funções interativas

e/ou

3) O serviço de Relações com investidores pode ser relacionado a um aumento de valor da empresa?

( ) $\operatorname{sim}$ ou ( ) não

A primeira questão reforça os critérios do processo eletivo dos melhores websites de relações com investidores e as demais complementam assuntos que pediam mais neutralidade, tais como: a mudança de comportamento quando surge 0 insucesso financeiro e a questão sobre o aumento de valor para a empresa resultante do serviço informacional prestado pela área de relações com investidores.

\subsection{O modelo de análise}

As respostas obtidas nas entrevistas foram submetidas a uma classificação inicial, identificando-se as unidades de análise para serem relacionadas. O tratamento analítico para as entrevistas tem como base a técnica da triangulação, descrita a seguir conforme a definição de Triviños: 
A técnica da triangulação tem por objetivo básico abranger a máxima amplitude na descrição, explicação e compreensão do foco em estudo. Parte de princípios que sustentam que é impossível conceber a existência isolada de um fenômeno social, sem raízes históricas, sem significados culturais e sem vinculações estreitas e essenciais com uma macro-realidade social. (TRIVINOS, 1987, P.138).

Análise endógena dos casos selecionados

Análise de representação e transferência da informação (Informação \& emissor)

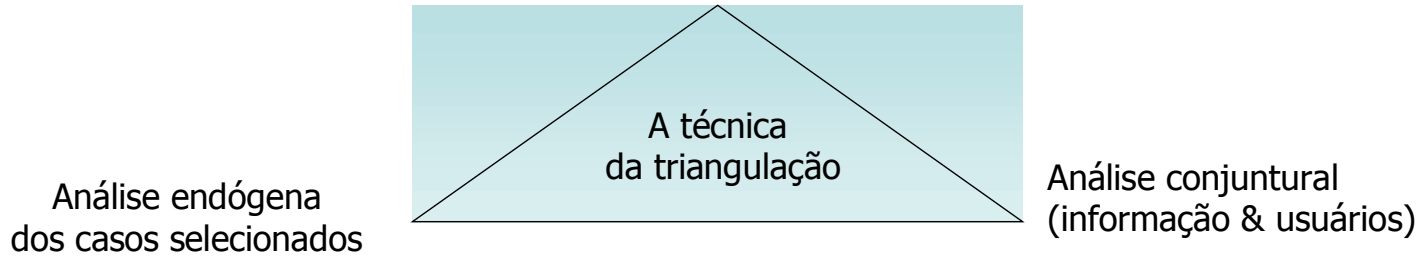

Para o tratamento das entrevistas do estudo foram determinadas unidades de análise de dois tipos, segundo Krippendorff (1990): unidades de registro - descrições que podem ser analisadas de forma isolada; e unidades de contexto informação contextual que pode incorporar-se à descrição de uma unidade de registro.

A especificação de cada unidade de análise constitui uma associação da proposição descrita acima com as áreas da Ciência da Informação, elaboradas por Belkin, de forma a cotejar a informação gerada pela Contabilidade com esta Ciência. As 5 áreas relacionadas à Ciência da Informação, descritas por Belkin (1978, p.58, apud Ingwersen), são:

1. transferência de informação em sistemas de comunicação humana formal e informal, ou seja o fluxo entre instituições;

2. a noção de informação desejada - compreensão da geração e desenvolvimento de necessidades de informação na sociedade, entre grupos específicos ou indivíduos; 
3. a eficácia dos sistemas de informação e transferência de informação métodos e tecnologias que promovem o desempenho e a qualidade da informação e dos sistemas de informação. Lida, portanto, com o desenvolvimento de teorias e modos para facilitar os processos de informação entre produtores e usuários;

4. as relações entre informação e produtor - conhecimento produzido e as formas de analisá-lo e representá-lo em sistemas de informação textuais;

5. a relação entre informação e usuário - estudo da relevância e o valor da informação.

O quadro foi elaborado com base na mesma referência bibliográfica, já considerando o contexto social, institucional e econômico de realização desse estudo de casos múltiplos.

\begin{tabular}{|c|c|c|}
\hline \multirow{4}{*}{$\begin{array}{l}\text { A técnica da } \\
\text { triangulação }\end{array}$} & $\begin{array}{l}\text { Análise endógena } \\
\text { dos casos selecionados }\end{array}$ & $\begin{array}{l}\text { Unidades de análise: áreas da } \\
\text { Ciência da informação (Belkin) }\end{array}$ \\
\hline & $\begin{array}{l}\text { Processos e produtos centrados nos } \\
\text { casos estudados }\end{array}$ & $\begin{array}{l}\text { a) A noção de informação desejada } \\
\text { b) A mediação }\end{array}$ \\
\hline & $\begin{array}{l}\text { Análise de representação e } \\
\text { transferência da informação } \\
\text { (Informação \& emissor) } \\
\text { Elementos produzidos pelo meio do } \\
\text { objeto de estudo }\end{array}$ & $\begin{array}{l}\text { a) Informação e produtor: a } \\
\text { geração e a representação da } \\
\text { informação. } \\
\text { b) Eficácia dos sistemas de } \\
\text { informação }\end{array}$ \\
\hline & $\begin{array}{l}\text { Análise conjuntural } \\
\text { (informação \& usuários) } \\
\text { Processos e produtos originados } \\
\text { pela estrutura sócio-econômica e } \\
\text { cultural do macro-organismo social } \\
\text { do objeto de estudo }\end{array}$ & $\begin{array}{l}\text { a) Relevância da Informação } \\
\text { b) Criação de valor }\end{array}$ \\
\hline
\end{tabular}

Quadro adaptado de Triviños (1987, p.138) 


\subsubsection{Análise endógena dos casos estudados}

Este primeiro item da técnica teve foco na análise crítica das respostas das entrevistas, acrescentando a postura da organização entrevistada e as intenções da comunicação e da mediação apresentadas.

Os parâmetros para a redução dos dados e as inferências foram: a) a noção de informação desejada - a compreensão da geração e desenvolvimento de necessidades de informação dos usuários de cada empresa entrevistada e b) a transferência de informação em sistemas de comunicação - formal e informal, privilegiando a mediação institucional (Belkin, 1978, p. 53 apud Ingwersen, 1990).

Com esta base foram descritos os serviços informacionais prestados, conforme cada empresa os divulga no website, em conjunto com a entrevista. Também foram contemplados as formas de aproximação com os usuários, as questões do nível de linguagem e segmentação.

\subsubsection{Análise de representação e transferência da informação}

Com abrangência sistêmica, os elementos do entorno do objeto de estudo constituíram uma observação da área de Relações com Investidores das companhias abertas em geral, com aderência às teorias expostas nas seções 2 e 3.

Estas unidades de contexto foram lidas conforme os itens: a) as relações entre informação e produtor - conhecimento produzido e as formas de analisá-lo e representá-lo em sistemas de informação textuais e b) a eficácia dos sistemas de informação - métodos e tecnologias que promovem o desempenho e a qualidade da informação e dos sistemas de informação (Belkin, 1978, p. 53 apud Ingwersen, 1990). 


\subsubsection{Análise conjuntural}

Finalmente, foi comparado o conceito de "relevância" elaborado pela Teoria da Contabilidade com o da Ciência da Informação, de forma a realçar as questões de comunicação envolvidas.

Também foram analisados: o papel do acionista na geração dos serviços informacionais, a avaliação da empresa e sua importância na interação mediativa, chegando-se a associações com a confiança, em sua conotação filosófica.

Este enfoque foi norteado pela última área identificada por Belkin: a relação entre informação e usuário - estudo da relevância e o valor da informação (Belkin, 1978, p. 53 apud Ingwersen, 1990).

\subsection{Integração da Ciência da Informação e da mediação das informações contábeis}

As bases teóricas expostas nas seções prévias estão inseridas em cada unidade de análise para descrever, explicar e criticar o fenômeno estudado, qual seja a mediação institucional realizada pelas empresas em consonância com a função comunicativa da Contabilidade.

A "análise endógena dos casos estudados" (item 4.2.1) tem base nas entrevistas com as empresas e os contrapontos do grupo de controle. Esse item trouxe grande conformidade com as teorias de Relações Públicas, tanto os fundamentos como as práticas realizadas pelas empresas pesquisadas.

A "análise de representação e transferência da informação" (item 4.2.2) está relacionada às seções 2 (a mediação institucional sob a ótica da Ciência da Informação) e 3 (análise Descritiva das "Relações com Investidores"). A "análise conjuntural" está fundamentada nas seções 2 (Teoria Contábil e contexto institucional e a mediação institucional sob a ótica da Ciência da Informação).

Buscou-se com os temas principais do questionário, os resultados da vivência das empresas que se destacam no cenário nacional e internacional, como direcionadores das análises. E destas, surgem as inferências e considerações finais. 


\section{Seção 5: Análise interpretativa e considerações finais}

\subsection{Análise endógena dos casos estudados}

Em concordância com o modelo de análise proposto na seção 4, esta primeira análise das entrevistas apresenta o modo pelo qual as instituições processam e enviam as informações e também as formas de aproximação com os usuários. Ela teve como enfoque a postura da organização entrevistada e os objetivos da comunicação e da mediação praticadas.

A redução dos dados e as inferências, nesta análise individualizada dos casos, seguem os seguintes parâmetros, já apresentados à p. 79, a saber: a) a elaboração da transferência de informação em sistemas de comunicação humana formal e informal; e b) a noção de informação desejada - a compreensão da geração e desenvolvimento de necessidades de informação na sociedade, entre grupos específicos ou indivíduos (Belkin, 1978, p. 53 apud Ingwersen, 1990).

As descrições, nos subitens a seguir, foram baseadas no roteiro da entrevista.

\section{Descrição das empresas estudadas}

\subsubsection{O Banco Bradesco}

Com uma equipe de cinco pessoas, o setor de relações com investidores do Bradesco processa as informações contábeis provenientes das demais áreas do banco e as apresenta, principalmente, no website, em relatórios anuais impressos, no jornal próprio trimestral "Acionista sempre em dia", na Revista Bradesco, nas diversas reuniões de road shows, conference calls e nos órgãos oficiais como Comissão de Valores Mobiliários (CVM) e Bovespa. Internacionalmente, estas informações são apresentadas na Security Exchange Commission (SEC), New York Security Exchange (NYSE), ambas americanas e na espanhola Latinoamerica en Euros (Latibex). 
A forma de divulgação considerada como principal pelos entrevistados é o website. Nele, os serviços de Relações com investidores aparecem à esquerda da primeira página (link Relações com Investidores) e dão acesso a informações de apresentação, como "Visão geral" que abre para seções como "História", "Conheça o Bradesco", "Missão e estratégia", entre outros. O Bradesco tem a seguinte missão, como empresa:

\begin{abstract}
Nosso principal objetivo é consolidar nossa posição como a principal instituição financeira privada no mercado brasileiro, que presta uma gama completa de serviços, aumentando nossa rentabilidade, maximizando valor para nossos acionistas e gerando um retorno acima da média em comparação com outras instituições do setor financeiro brasileiro.
\end{abstract}

O setor de Relações com Investidores do Bradesco trabalha, portanto, conjuntamente com as demais áreas para a conquista desse objetivo principal. Seu conhecimento a respeito dos investidores, descrito na entrevista, possibilita o uso de diversas técnicas de comunicação e relações públicas.

\title{
5.1.2 O Banco Itaú
}

Colecionador de prêmios e grande inovador na área de Relações com Investidores no Brasil, o Banco Itaú possui uma equipe de oito pessoas neste setor, provenientes, em sua maioria, da área de controladoria do banco. Esta equipe trabalha em regime de funções compartilhadas. A filosofia de trabalho descrita na entrevista é de que não há como a área de Relações com Investidores funcionar de forma compartimentada - dito de outro modo, as funções e o conhecimento devem ser comuns à equipe.

As informações são angariadas nos demais setores, modeladas e apresentadas nos meios de comunicação do banco, sendo o website o mais completo. Porém, existem publicações encadernadas de relatórios, um folheto informativo direcionado ao acionista - "Itaú em foco", entre outros.

Na página inicial do website, a opção de acesso à área de Relações com Investidores aparece na faixa inferior do website, à esquerda. Cabe notar que, na 
página específica, além da história da empresa e outras informações-padrão, há o item "Política de RI" e, dentro deste, "quem somos" com esclarecimentos conceituais e posturas sobre a visão desta área na empresa:

O profissional de "Relações com Investidores" fornece informações sobre a empresa para, principalmente, analistas de investimentos, acionistas e investidores; auxiliando na tomada de decisão de investir na ação desta empresa.

O objetivo principal da área de Relações com Investidores do Banco Itaú Holding Financeira S.A. é agregar valor aos acionistas do Banco Itaú Holding Financeira S.A.. Para isso, a área desenvolve um trabalho contínuo que inclui planejamento estratégico, implantação coordenada, acompanhamento permanente, avaliações e feedback. Nossa política de Relações com Investidores é fornecer subsídios que sejam suficientes para a decisão de investir em ações do Itaú Holding Financeira, através da divulgação de informações com transparência e qualidade. Respeitando sempre os princípios legais e éticos, buscamos consolidar e manter a imagem de liderança e inovação do Banco Itaú Holding Financeira S.A. junto ao Mercado de Capitais.

Os usuários são classificados principalmente como profissionais de investimentos, investidores e acionistas, porém vem crescendo a mídia especializada (jornalismo econômico) e estudantes de todo o país.

Os investidores estrangeiros são institucionais e alcançam $1 / 3$ do capital social do banco, os investidores nacionais são conhecidos por cadastro, podendo ser estratificados de várias formas. Desta interação nascem os avanços na mediação, por meio de esclarecimentos mais didáticos nas publicações. Quanto à elaboração das apresentações, há uma busca constante de inovação de forma a expor as informações contábeis, com tecnologia e segmentação de público-alvo.

\subsubsection{A Petrobras}

Com vinte e quatro pessoas trabalhando no setor de Relações com Investidores, a Petrobras tem a maior equipe entre as empresas entrevistadas. Ela ocupou a primeira posição na premiação de melhor website de Relações com Investidores. 
Iniciado por seções de apresentação, como introdução, história, estatuto social e relatórios, a página de Relações com Investidores da Petrobras traz uma inovação - um tratamento particularizado ao investidor individual, intitulado "pessoa física", conforme descrito na página específica:

\begin{abstract}
A Petrobras, reconhecendo a importância de seus atuais e potenciais investidores individuais (acionistas e debenturistas) e reforçando sua política de tratamento equânime a todos os seus públicos de interesse, criou uma página dedicada a você, investidor individual.
\end{abstract}

Além de contatos da própria empresa, os investidores são também identificados por empresas de consultoria contratadas e há informações customizadas para cada grupo de investidores, embora todas as informações são de acesso livre a quaisquer usuários.

As informações são geradas na própria empresa com a cooperação das áreas de negócios, passando a estar disponíveis no website desde 1998. Os relatórios e formulários apresentados às bolsas de valores permanecem sem substituições e as informações dedicadas ao mercado e aos acionistas recebem atualizações.

O caminho de busca dos usuários é apontado pela empresa como primeiramente a consulta ao website e, após, as vias de contato direto.

A Petrobras realiza estudos de percepção para verificar o acréscimo de valor que o trabalho de Relações com Investidores traz, mas não relaciona a valorização financeira da empresa ao crescimento deste programa.

\title{
5.1.4 O Unibanco
}

Para o setor de relações com investidores do Unibanco, é importante que um profissional desta área tenha conhecimento sobre os domínios de Contabilidade, Finanças, Mercado de Capitais e da estratégia tanto da própria empresa quanto das concorrentes. Esta equipe é formada por oito pessoas, sendo que cinco delas são analistas de investimentos. 
O principal usuário, citado na entrevista, é denominado "investidor", ou seja, aquele que tenha ações do Unibanco ou que possa se interessar por comprálas. Isto inclui desde pessoa física até quem o orienta nas negociações - o profissional de investimentos. O website também é apontado como uma apresentação da empresa para quem quer conhecê-la, como os exemplos citados de alguém que esteja procurando emprego ou procurando fazer negócios.

Considerando que uma informação possa servir tanto ao usuário pessoa física, quanto ao usuário institucional, esta equipe prefere elaborar "camadas de informação" que possam atender a usuários com distintos níveis de conhecimento da linguagem de especialidade contábil.

Outra forma de identificação de usuários apontada é a observação do processo de busca no website. A partir da verificação dos itens acessados, a informação mais demandada é posta de forma proeminente. Cabe notar que esta observação quantitativa não foi citada sem a junção do aspecto da sensibilidade no contato falado com usuários.

O Unibanco também faz pesquisa terceirizada, contratando empresas de consultoria externa para fazer a crítica do website, o mapeamento de questões sobre o melhor conteúdo e forma de apresentação e ainda sobre o processo de divulgação.

Quanto à preparação das informações a serem apresentadas, foi feita uma classificação geral em dois tipos: as informações recorrentes (como as demonstrações contábeis trimestrais) e as pontuais ou especiais (como novos negócios, fatos relevantes, mudanças de legislação etc.). Junto à informação contábil legalmente exigida, a qual é elaborada em linguagem de especialidade, é emitido também o chamado "press release" (um acompanhamento em linguagem menos técnica e com realces em alguns fatos e ou valores).

A "boa divulgação" foi diferenciada de "bons resultados" (lucratividade), sendo associada à redução de incertezas do investidor (usuários) por meio da clareza, pois:

A incerteza é um fator de desconto no preço do papel, à medida que você vai removendo as incertezas, você vai removendo um dos fatores de desconto no preço do papel até chegar ao ponto de que aquilo deixa de ser um fator inibidor para o investidor. Quanto mais transparente for a empresa, quanto mais tranqüilo for para a pessoa 
saber o que está acontecendo com o investimento dela, melhor aquilo vai ser para o preço da ação. (Trecho da entrevista).

Dessa forma, a valorização da empresa foi associada à clareza e a transparência das informações divulgadas.

\subsubsection{A Ultrapar}

Responsável pelo Relatório Anual da empresa, a área de Relações com Investidores da Ultrapar está envolvida na representação publicitária da empresa, uma vez que esta divulgação é considerada, conforme a entrevista, "a peça publicitária institucional mais forte aqui dentro." A equipe é formada por cinco pessoas e destaca que a comunicação em todos os níveis é essencial para a realização do trabalho.

A empresa se vale muito de cadastro próprio, além de um programa de informática norte-americano que facilita identificação de quem entra em contato, para montar uma base de dados própria sobre os usuários, seus interesses e consultas principais.

Com um conjunto de acionistas formado, em grande parte, por investidores institucionais, a Ultrapar apresenta uma comunicação única, sem diferenciação e sem os jornais e revistas explicativos (para os acionistas com pouco conhecimento da linguagem contábil).

A função de Relações com Investidores definida na entrevista é a de explicar a informação contábil e como está a empresa. A riqueza da função é vista como captar a percepção do usuário e suas necessidades informacionais.

Embora não tenha sido citada nenhuma barreira na obtenção dos dados internamente, é na compilação da informação e na elaboração da forma de apresentação que surgem divergências entre a área de Relações com Investidores e as demais áreas. 


\section{a) A elaboração da transferência de informação}

O principal meio de comunicação, podendo ser descrito como a principal forma de acesso para quase todos os usuários, é o website. Em cada um deles há níveis diferentes de tecnicidade e possibilidade de interação. A Petrobras tem um link para "Pessoa física" com "Perguntas e Respostas", "Chat", e histórico de dividendos distribuídos; o Unibanco com "Opinião do mercado" e "Fundamentos"; o Itaú com "RI em um clique" e "Ferramentas de RI"; o Bradesco com "Universo RI", "Serviços" e "Glossário"; e a Ultrapar com "Destaques" e "Últimas novidades".

Cabe, então, uma primeira caracterização do maior grupo de usuários: são pessoas (e instituições) com acesso a informações digitalizadas, mas nem todas lêem informações na linguagem de especialidade da contabilidade. Outra característica da tecnologia presente no fluxo de informação é a ausência de problemas com armazenamento, isto é, não houve menção a problemas com arquivamento, as informações são dispostas e acrescentadas no website da empresa, sem que haja substituição dos arquivos anteriores.

A maioria das empresas entrevistadas desenvolveu produtos segmentados para os níveis de linguagem identificados nos usuários e, além disso, criou oportunidades para que estes usuários participem do processo editorial. Este conjunto de ações concorda com a descrição de Giangrande:

A compreensão das demandas, expectativas e necessidades nos
vários níveis sociais dos seus públicos valorizou a segmentação, o
tipo de abordagem e a linguagem utilizada, desembocando na
necessidade de uma verdadeira interação com os mesmos, que vem
sendo apontada pelos técnicos em gestão como um dos ingredientes
de sucesso e permanência da empresa. (GIANGRANDE, 2001, p.
190).

Entre estes produtos desenvolvidos pelas empresas entrevistadas estão os panfletos didáticos para investidores não institucionais, tais como:

- Petrobras: "Jornal do acionista";

- Itaú: jornalzinho "Itaú em foco" e

- Bradesco: jornalzinho "Acionista sempre em dia" 
Uma área que reúne o trabalho desenvolvido por outros departamentos, transforma-o em informação contábil-financeira e o divulga, certamente atrai barreiras de comunicação. Nas entrevistas foi citado o árduo trabalho de "conquistar o respeito" das outras áreas e esta conquista veio associada a uma postura de imposição hierárquica.

As barreiras ou problemas que interferem no processo comunicativo (Kunsch, 2002, p. 74), são relacionadas a situações derivadas da moderna divisão do trabalho. Por exemplo: os responsáveis por novos negócios querem, também, o reconhecimento por realizá-los. Sendo assim, quando a área de relações com investidores surge com o interesse de saber sobre os novos produtos ou negócios em desenvolvimento para, então, julgar se merece ou não divulgação, também surgem reações de desconfiança.

As barreiras citadas nas entrevistas se materializam na forma de "falta de agilidade" nas respostas às questões da área de relações com investidores, especialmente dos demais setores das empresas envolvidos a "negócios". Outro escape à resposta é adiá-la, em nome de consultar um superior se aquela solicitação pode ou não ser respondida.

Para kunsch (2002), elementos como a audição seletiva, juízo de valor, credibilidade da fonte, problemas de semântica, filtragem, linguagem intragrupal, diferenças de status, pressões de tempo e sobrecarga de informação são barreiras muito recorrentes nas organizações. Sobre a "credibilidade da fonte", a mesma autora escreve:

O nível de credibilidade que o receptor atribui ao comunicador afeta diretamente suas reações em relação às palavras e às idéias do comunicador. Se ele não acreditar na fonte, naturalmente se armará e tenderá a reagir de forma negativa às mensagens recebidas. (KUNSCH, 2002, p. 76).

E sobre as "diferenças de status":

Essas diferenças contribuem para aumentar a competição entre pessoas e departamentos em torno do poder e para o hiato de comunicação entre os vários níveis, sobretudo entre superiores $e$ subordinados. (KUNSCH, 2002, p. 77). 
Uma das empresas citou que seu reconhecimento interno veio após o reconhecimento do público externo à empresa. Ou seja, prevaleceu a idéia de que o que é bom para o crescimento da empresa, deve ser valorizado.

\section{b) A noção de informação desejada}

Um serviço informacional, que trabalha com documentos em linguagem de especialidade e se propõe a atender a todos os níveis de usuários, tem um grande desafio no que concerne a entender a informação que o usuário deseja recuperar.

A busca de aproximação com os usuários, planejada e realizada pelos setores de relações com investidores dos casos estudados, é intensa e avançada. Ela mostra um padrão que procede de uma análise de necessidades.

Uma análise das necessidades de informação abrangerá, então, cinco etapas:

1. Identificar os usuários e os usos da informação

2. Descrever a população-alvo e o ambiente

3. Identificar as necessidades dessa população

4. Avaliar as necessidades

5. Descrever, comunicar e implementar as soluções

(LE COADIC, 1996, p. 45).

Em todas as empresas estudadas, há diversas técnicas de conhecimento do usuário e de seus interesses, tais como cadastro de quem entra em contato, verificação de itens de maior acesso no website, estudos de percepção com empresas especializadas, eventos para segmentos específicos de usuários, apresentações variadas, contatos telefônicos e pela Internet, entre outros.

Por meio desta plataforma pró-ativa, estas empresas aprimoram seus conhecimentos sobre as informações desejadas, além das necessárias. Dito de outro modo, fornecer informações sobre a companhia aberta é uma obrigação legal para todas elas e as demonstrações contábeis já o fazem, em linguagem especializada. 
Entretanto, explicar os conceitos da terminologia, fornecer dados de contexto econômico, facilitar a comparação, abrir serviços de atendimento, tornar-se acessível etc., vão além da exigência legal. Neste aspecto, encontra-se uma grande diferença entre este serviço de divulgação de informações promovido pelos setores de relações com investidores e a função de divulgação tradicional, como a Contabilidade a pratica.

Infelizmente, no enfoque e nas práticas tradicionais a questão não é analisada em si mesma; o que se examina é se ela remete a um tipo de fonte onde se espera encontrar a resposta (procedimento orientado para o emissor). (LE COADIC, 1996, p. 46).

Tradicionalmente, um sistema de informação desenvolvido pela Contabilidade tem como ponto de partida uma decisão. Ou seja, é a Contabilidade (emissora) quem seleciona as informações adequadas para dar suporte à decisão. Em se tratando de comunicação, nem sempre a relevância para o sistema emissor significa relevância para o usuário.

O conjunto de processos e produtos de mediação realizado pelas companhias abertas sugere uma nova possibilidade de execução da função comunicativa componente da Teoria da Contabilidade.

\subsection{Análise de representação e transferência da informação}

No Brasil, a exposição de informações sobre companhias abertas, comum a todas elas, é a publicação em um jornal oficial. Esta é uma publicação anual obrigatória segundo a Lei $n^{\circ} 6.404$ de 1976. Esta obrigatoriedade foi considerada obsoleta pelas empresas entrevistadas, apenas a Petrobras a considerou importante, mesmo assim referindo-se a fatos relevantes e avisos a acionistas. As demais julgaram uma obrigação de custo elevado em relação ao benefício do alcance do público, entre outros comentários.

Além desta exigência legal, como agente determinante do entorno dos casos estudados está o conjunto de regulamentações da Comissão de Valores 
Mobiliários (CVM). Esta, por meio de instruções normativas, estabelece a presença de um diretor de Relações com investidores em cada companhia aberta, dá sugestões de explicações, regulamenta e fiscaliza o mercado para que haja um tratamento equânime dos investidores. A ação da CVM e os principais pronunciamentos desse órgão, relacionados a esta pesquisa, estão nos anexos.

\section{a) Informação e produtor: a geração e a representação da}

\section{informação}

Quanto às relações entre informação e produtor - conhecimento produzido e as formas de analisá-lo e representá-lo em sistemas de informação textuais (Belkin, 1978, p. 53 apud Ingwersen, 1990), destaca-se a inovação tecnológica constante. As empresas entrevistadas têm em comum um alto padrão de tecnologia para veicular a transferência das informações contábil-financeiras e demais conteúdos, tanto os interativos como os informes e comunicados.

O meio de transferência, com tamanho avanço tecnológico, tornou-se o principal agente facilitador da mediação. As formas de representação das informações contábil-financeiras extrapolam os modelos de demonstrações contábeis, incorporando, não só as novas tecnologias de difusão, mas também conceitos inovadores de editoração. Esta representação abarca o contexto de referência, glossário da terminologia, hipertextos e outros elementos que estimulam o contato contínuo, ou o fluxo, conforme Barreto:

Um ato de comunicação se efetiva quanto um emissor, remetente envia uma mensagem a um destinatário, receptor. Para se realizar de forma eficaz a mensagem necessita de um contexto de referência e este contexto precisa ser acessível ao receptor (...). É necessário ainda um código, total ou parcialmente comum ao emissor e ao receptor e finalmente um contacto, isto é, um canal físico e uma conexão psicológica entre o emissor e o receptor, que o capacite a entrarem e permanecerem em contato. (BARRETO, 2002, p. 50).

Os produtos gerados pelo serviço informacional demonstram concordância entre a apresentação e a significação, ou seja, folhetos menores e mais didáticos 
para acionistas não institucionais, e impressos mais técnicos e encorpados para os profissionais de investimento.

Outro aspecto notável nos produtos e serviços é o empenho em busca da assimilação.

\begin{abstract}
Agente mediador da produção de conhecimento, o conceito de assimilação da informação é um processo de interação entre $o$ indivíduo e uma determinada estrutura de informação, que gera uma modificação em seu estado cognitivo, produzindo conhecimento, que se relaciona corretamente com a informação recebida. É um estágio qualitativamente superior ao acesso e uso da informação. (BARRETO, 2002, p. 49).
\end{abstract}

Esta assimilação da informação, conforme o emissor deseja, foi um ponto sensível nas entrevistas. O serviço informacional de relações com investidores almeja sanar dúvidas, indicar a recuperação da informação e permanecer disponível.

Havendo um objetivo a comunicar e uma resposta a obter, o comunicador espera que a sua comunicação seja a mais fiel possível. Por fidelidade, queremos dizer que ele obterá o que quer. Um codificador de alta fidelidade é o que expressa perfeitamente o que a fonte quer dizer. Um decodificador de alta fidelidade é o que traduz a mensagem para o receptor com total exatidão. Ao analisar a comunicação, interessa-nos determinar o que aumenta ou reduz a fidelidade do processo. (BERLO, 1999, p.41).

Este aspecto pode ser observado nas respostas às questões 7 e 8 do formulário de entrevistas, que se referem ao processo de geração da informação. Tais respostas apresentam o conquistado comprometimento de outras áreas da empresa em fornecer os dados solicitados e enaltecem a capacidade de armazenamento de informações para consultas, ambos analisados aqui como elementos de fidelidade do processo.

Evidentemente, conseguir mediar a informação de forma que o usuário se aproprie do significado pretendido está relacionado intrinsecamente ao risco do negócio e à imagem institucional que se deseja manter, conforme a teoria de Relações Públicas:

A comunicação institucional é a responsável direta, por meio da gestão estratégica das relações públicas, pela construção e 
formatação de uma imagem e identidade corporativas fortes $e$ positivas de uma organização. (KUNSCH, 2002, p. 164).

As áreas de relações com investidores estudadas utilizam diversos instrumentos da comunicação institucional, conforme apresenta Kunsch (2002), tais como: relações públicas, jornalismo empresarial (boletins e revistas), assessoria de imprensa, editoração multimídia, imagem corporativa (o que os públicos pensam), identidade corporativa (o que a empresa é, faz e diz), propaganda institucional, marketing social e marketing cultural.

\section{b) Eficácia dos sistemas de informação}

Este assunto, analisado como unidade de contexto, tem sua validação no olhar do receptor. Pensar na eficácia do sistema de informação produzido pelo setor de Relações com investidores das empresas estudadas passa pelo conceito de utilidade da informação recuperada.

O comportamento dos usuários, suas preferências na busca, a informação - tanto a desejada quanto a importante - na decisão de comprar, vender ou manter ações da empresa são oferecidas com tecnologia e técnicas de comunicação, de forma a incrementar sua utilidade.

É importante notar que a análise de comportamento de usuário, assim como desenhos de intermediação crescentemente tocam as relações entre as representações dos sistemas de Recuperação de Informação, funções e comportamentos específicos de agentes intermediários e características de usuários. Estamos na fronteira da combinação de modelos variados e complexos com teorias $e$ estruturas para a projeção de sistemas interativos de Recuperação de Informação, envolvendo mecanismos intermediários baseados em conhecimento. (INGWERSEN, 1992, p. 120).

Estes sistemas interativos de recuperação de informação têm se mostrado eficazes. Os maiores usuários deste serviço informacional, conforme identificação nas entrevistas, são os profissionais de investimento, embora a utilização por parte de investidores individuais esteja aumentando, segundo medições feitas pelas próprias empresas. Este grupo de usuários, receptores, foram portanto ouvidos como grupo 
de controle para contrabalançar as entrevistas, de duas formas: alguns especialistas, individualmente, e outros analistas de mercado responderam a um pequeno questionário relacionado às perguntas feitas às empresas, conforme descrito na seção 4, item 4.1.4.

As respostas da pesquisa com os profissionais de investimento revelaram a seguinte ordem de importância nas características de um bom website:

1. Rapidez na divulgação de informações relevantes;

2. Conteúdo e profundidade das informações;

3. Interatividade com o usuário;

4. Tecnologia e navegabilidade.

Estas características foram apontadas como indicadores de eficácia por estes usuários.

Outros indicadores de eficácia dos sistemas de informação são 0 crescimento e o enriquecimento dos serviços prestados. O estudo de casos múltiplos foi feito com empresas premiadas em diversos eventos, por serviços informacionais. Esta evolução está relacionada às formas de apresentação que produzem um resultado aprovado em termos de conteúdo recuperado, conforme Epstein:

O conteúdo informacional de uma mensagem é a medida da mudança da incerteza do receptor antes de receber a mensagem para depois de recebê-la. (EPSTEIN, 1988, p. 36).

Existem programas de computação desenvolvidos para as demandas habituais de um setor de relações com investidores. Dentre os casos estudados, uma empresa citou a compra de um destes e duas outras comentaram as facilidades de estratificação de seus usuários investidores a partir dos cadastros e registros em seus sistemas. É possível segmentar investidores e usuários por idade, valor investido, tempo de posse dos títulos, questões mais comuns, entre outras variações. Configura-se, portanto, o conceito da comunicação dirigida:

Comunicação dirigida é o processo que tem por finalidade transmitir ou conduzir informações para estabelecer comunicação limitada, orientada e freqüente com determinado número de pessoas homogêneas e identificadas. (ANDRADE, 1985 apud FERREIRA, 2001, p. 73) 
À comunicação dirigida cabe a elaboração da mensagem eficiente, eficaz e apta a produzir os efeitos desejados no público receptor. (FERREIRA, 2001, p. 73).

O "tempo de consulta" que um usuário possa ter ou dispor para consultar o website, fazendo sua busca, é considerado como um fator determinante de muitos serviços e formas de apresentação. Nos casos estudados há a possibilidade de se obter informações com um "click", anunciadas em destaque no portal de relações com investidores. Este valor na geração da informação aparece, por exemplo, no texto da entrevista:

O que uma pessoa com meia hora de tempo precisa saber sobre $o$ Banco? O que uma pessoa com mais tempo...? E assim sucessivamente até aquela pessoa que lê o site do Banco com freqüência...(entrevista do Unibanco).

A análise da transferência de informação, em resumo, mostra uma evolução na prestação de serviços fortemente fundamentada na exploração eficaz de recursos tecnológicos.

\subsection{Análise conjuntural}

Este terceiro vértice da análise da triangulação enfoca as relações entre a informação e os usuários sob o macro contexto sócio-econômico. Tem como base o referencial teórico da seção 2 e outros estudos complementares.

A comunicação tem impacto na valorização da empresa. Essa é a constatação do estudo de Howard Stock (2003), que propõe a inclusão da estrutura de comunicação das companhias abertas como ativos intangíveis no Balanço Patrimonial.

O desenvolvimento da comunicação pela Teoria da Contabilidade tem, como principal produto, a denominada evidenciação de informações contábilfinanceiras. 
A orientação a ser seguida para a elaboração da evidenciação consiste na observação das características qualitativas das demonstrações contábeis, aplicáveis a todos os países, além de exigências legais e padrões de elaboração.

Uma vez que essa orientação é resultado de pesquisas, práticas do mercado financeiro, instruções de órgãos oficiais e entidades de classe de vários países, observa-se que a busca de fornecer a informação que seja útil para a tomada de decisões econômicas está direcionada ao processo de escolhas do usuário, conforme o modelo a seguir.

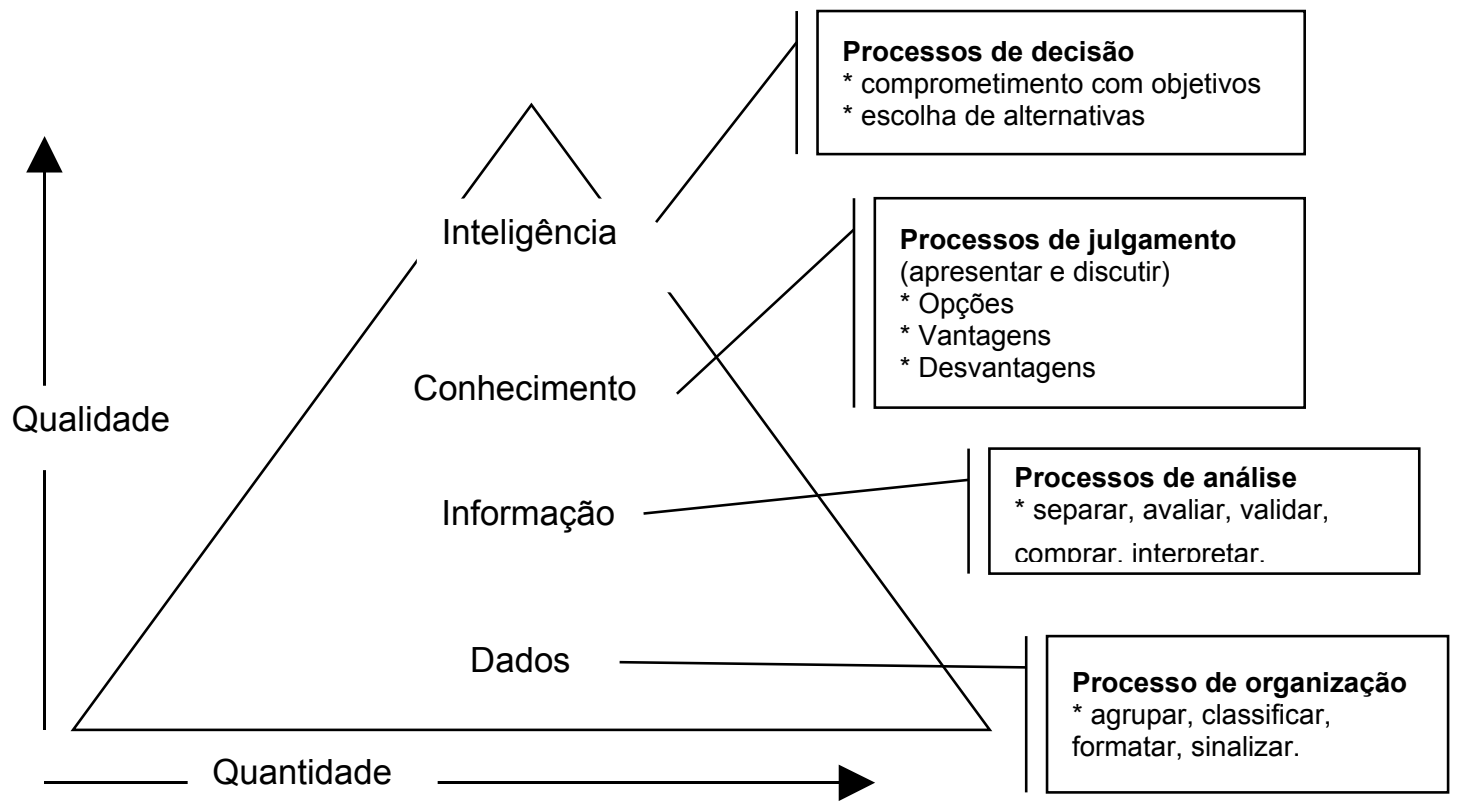

Fonte: Continuum dado-conhecimento por Ponjuan (1998, p.2) apud Marchiori (2002, p. 53)

Pode-se notar que, pelo modelo acima, o processo de decisão aparece como uma etapa com maior qualidade de conhecimento. 0 que a evidenciação de informações contábeis tenta suprir é esta etapa, enquanto que os demais sistemas de informação buscam oferecer conhecimento necessário ao processo de julgamento, etapa anterior. Porém, as decisões são possíveis se há um certo conhecimento do domínio. É nesse contexto que o tratamento da busca de informações pela ótica da Ciência da Informação se difere do tratamento pela Contabilidade, conforme discutido a seguir. 


\section{a) Relevância da informação}

A evolução implementada pelo sistema de informação das áreas de relações com investidores está em enfocar o conceito de Relevância conforme a Ciência da Informação. Segundo Le Coadic (1996, p. 82), "a relevância é uma relação entre um documento e uma questão" e, para a contabilidade, é a relação entre uma informação e uma decisão. Textualmente:

As informações são relevantes quando influenciam as decisões econômicas dos usuários, ajudando-os a avaliar o impacto de eventos passados, presentes ou futuros, confirmando ou corrigindo as suas avaliações anteriores. (IASB, 2001, p. 49).

O trecho acima ajuda a elucidar uma das inferências básicas desta pesquisa, relacionada à hipótese 1: "A Contabilidade deve empregar o conceito de mediação, segundo a Ciência da Informação, para melhorar sua função comunicativa."

A Teoria Contábil desenvolve sua função comunicativa ainda do ponto de vista do produtor da informação. Ela, conhecedora do universo de informações necessárias e suficientes a uma ou mais decisões econômicas, se encarrega de fornecer este conteúdo ao usuário.

A tarefa básica do Contador é produzir e/ou gerenciar informações úteis aos usuários da Contabilidade para a tomada de decisões. (IUDíCIBUS e MARION, 2000, p. 43).

Sob a ótica da Ciência da Informação, o excesso de especialização pode gerar um desserviço ao entendimento do usuário:

É óbvio que o vulto de conhecimento da fonte sobre o assunto influenciará a mensagem. Ninguém é capaz de comunicar aquilo que não sabe; ninguém comunica com a máxima efetividade material que não conhece. De outro lado, se a fonte sabe 'demais', se é ultraespecializada, poderá errar pelo fato de suas habilidades comunicadoras serem empregadas de maneira tão técnica que 0 receptor acabe não entendendo. (BERLO, 1999, p. 49). 
Ainda na Teoria da Ciência da Informação, a informação relevante é a que responde a pergunta do usuário, não a pergunta que ele deveria ter feito, de acordo com a visão do produtor.

No caso dos sistemas de informação, o objetivo principal é fornecer a informação relevante ao usuário. A relevância mede, assim, a correspondência que existe entre um documento e uma questão. (LE COADIC, 1996, p. 63).

Isto é, busca recuperar a informação solicitada e não simplesmente a que julgar conveniente. Com base na pesquisa de campo, este comportamento aparece em especial nas ligações telefônicas - a empresa atende ao usuário em sua questão e, depois disso, sugere ou explica complementos que possam influenciar no tipo de decisão. Essa seqüência de procedimentos gera a relevância para o usuário.

\section{b) Criação de valor}

A criação de valor para o acionista é um tema de grande discussão nas empresas e nas disciplinas relacionadas ao mercado de investimentos. A criação de valor, como algo relacionado à mediação institucional, foi um tema de questão na pesquisa aplicada a cinco empresas. Entretanto, embora reconhecendo o crescimento dos serviços de mediação, os entrevistados não possuíam uma metodologia para medir a valorização da empresa em conseqüência desses serviços. Para esta generalização, juntou-se a opinião do grupo de controle entrevistado, que identificou a valorização da empresa aos serviços de relações com investidores, com outras pesquisas já realizadas sobre o tema.

Um estudo de Silva e Alves (2004) envolvendo 150 companhias abertas do Brasil, Argentina e México revelou que existe associação entre o nível de informação contábil-financeira apresentada na Internet por estas companhias e o valor das mesmas.

A "cartilha" da Associação Nacional de Investidores do Mercado de Capitais - ANIMEC, que aponta 22 itens de valorização de uma empresa para os 
acionistas, apresenta, dentre estes itens, "política de relações com investidores", "website de relações com investidores" e "transparência" (o texto completo está nos anexos).

A valorização da empresa em decorrência dos serviços de mediação de informações contábeis que ela presta está inserida na criação de valor para o acionista. Essa criação de valor tem relação com o conjunto de alterações administrativas incluso na Governança Corporativa, conforme apresentado na seção 2 (item 2.1.2).

O que se percebe com a implantação de princípios de Governança Corporativa, juntamente com um bom serviço informacional de Relações com Investidores, é uma empatia relacionada à confiança do investidor.

Conforme o estudo de Niklas Luhmann (1996), sobre a confiança,

Mostrar confiança é antecipar o futuro. É comportar-se como se o futuro fosse certo. (p.15)

A complexidade do mundo futuro se reduz por meio do ato da confiança. Ao confiar, compromete-se com a ação como se houvesse somente certas possibilidades no futuro. (p.33)

A confiança somente está envolvida quando a expectativa confiável faz uma diferença para uma decisão, de outro modo, o que temos é uma simples esperança. (p.40).

A criação de valor para o investidor, usuário do serviço de informação de uma empresa, está alinhada com a geração de expectativas confiáveis sobre o futuro dessa empresa, a ponto de influenciar a decisão de investir desse usuário.

A confiança é um conceito fundamental no ato de investir, isso pôde ser observado no estudo de casos múltiplos, inclusive como um elemento que influencia no valor do papel negociado da empresa.

Conforme analisa Parente:

A prosperidade americana decorre da confiança do público investidor em suas empresas e, em conseqüência, no mercado de capitais.

No Brasil, as companhias, por não garantirem transparência nas informações, são obrigadas a lançar suas ações por um valor inferior ao que suas condições econômicas permitiriam, deixando de ganhar um prêmio de seus acionistas da ordem de 22,9\%. (PARENTE, 2002, p.83). 
Em busca do interesse do investidor pela empresa é que se desenvolve a transparência de gestão e de informação, embutidas na implementação da Governança Corporativa e na mediação das informações contábil-financeiras efetuada pelo setor de Relações com Investidores das mesmas. 


\section{Considerações Finais}

Esta pesquisa foi desenvolvida em torno de três objetivos, que podem ser resumidos como: a) relacionar os serviços informacionais das empresas aos paradigmas de transferência de informações de domínios específicos; b) apresentar e analisar as práticas de mediação institucional das empresas estudadas; e c) apresentar alternativas de comunicação da informação contábil para os investidores. Com esses objetivos, o marco teórico selecionado agrupou conceitos da Teoria da Contabilidade e da Ciência da Informação com as descrições da área de Relações com Investidores. A metodologia escolhida foi um estudo de casos múltiplos.

Com relação aos objetivos propostos, observou-se que a Contabilidade tradicionalmente classifica os usuários das informações que gera por categorias de interesse, afinal, ela se dispõe a dar a informação relacionada às decisões desses usuários. Dessa forma, lê-se, nos textos teóricos contábeis, que os usuários podem ser classificados como investidores, empregados, credores etc.

Diferentemente da classificação de usuários da informação feita pela Contabilidade, uma técnica da transferência de informação utilizada pelas companhias abertas e que esta pesquisa elucidou, foi a classificação inicial de públicos em interno e externo. A função comunicativa da Contabilidade terá, nesta forma de classificação de usuários, um fundamento teórico de grande aplicação. É necessário dividir os usuários em internos e externos, primeiramente, para depois classificá-los conforme suas necessidades decisoriais. Para os usuários externos, o emprego de técnicas de mediação e de comunicação vindas de Relações Públicas são os implementos a ser introduzidos.

A partir dessa elucidação, pode-se classificar as demonstrações contábeis como discursos. Na ótica da Ciência da Informação, o discurso da Contabilidade, exercido por meio das demonstrações, é argumentativo. Dito de outro modo, as 
demonstrações contábeis são formas de abertura de informações para público externo à empresa e possuem o objetivo de convencer. Para o público interno, o discurso utilizado e os relatórios utilizados são outros. Essa constatação foi obtida por meio da identificação de técnicas de persuasão provenientes de Relações Públicas presentes na mediação das informações contábeis praticada pelas companhias abertas.

Ainda em torno dos objetivos da pesquisa, outro paradigma de transferência de informação de domínios específicos, empregado pelas áreas de relações com investidores, é o tratamento da linguagem de especialidade. 0 vocabulário técnico e as terminologias contábeis devem ser de conhecimento de um usuário desse tipo de informações. Porém, os usuários das informações contábeis divulgadas pelas companhias abertas têm diferentes níveis de conhecimento desse vocabulário. Para esse cenário, a exemplo dessas empresas, devem ser criadas formas facilitadas de acesso aos conceitos, além da abertura de um canal de comunicação interativa. Afinal, o nível de conhecimento do domínio está relacionado à independência de julgamentos e decisões. O que não pode ocorrer é o esvaziamento da significação da terminologia contábil, porque ela representa o conjunto nocional dessa especialidade.

Quanto à metodologia, o estudo de casos múltiplos realizado nesta pesquisa apresentou algumas características mais freqüentes, descritas nos seguintes parágrafos, na mesma ordem de assuntos do questionário.

As equipes são pequenas, com até oito pessoas. Embora haja uma hierarquia bem definida em todas as empresas entrevistadas, as funções são compartilhadas, sendo exigido um amplo conhecimento da empresa. Em todos os casos, os funcionários de cargos superiores já eram de áreas contábeis da empresa e com alguns anos de trabalho, quando então "migraram" para a área de relações com investidores. 
Os maiores usuários são os profissionais de investimento, também conhecidos como analistas de mercado de capitais. Tanto os investidores pessoas físicas quanto os investidores institucionais buscam os trabalhos desses profissionais por meio de suas corretoras. Para eles, não há impedimentos quanto à linguagem técnica. Estes usuários costumam freqüentar as reuniões de divulgação de resultados e acompanhar diariamente as informações apresentadas no website. Além destes, existem os usuários individuais que telefonam para dirimir dúvidas de suas consultas à Internet, independentemente.

As informações são extraídas do eixo contábil-financeiro da empresa, acrescido de dados de outras áreas. $O$ que se sobressai é o desejo de informar mais rápido e ser melhor compreendido. As empresas entrevistadas mantêm um desenvolvimento de novos materiais de comunicação, principalmente em forma de panfletos e jornais.

Os meios de divulgação utilizados, em geral, pelas companhias entrevistadas são similares. Além dos meios obrigatórios legalmente, como a divulgação na Comissão de Valores Mobiliários (CVM) e no Diário Oficial, há publicações feitas em jornais temáticos (Gazeta Mercantil, Valor Econômico etc.), porém o meio apontado como o principal é o website da empresa.

Depreende-se, pelas respostas, que a mediação é desenvolvida em função do conhecimento dos hábitos dos usuários. Com grande ajuda da tecnologia, as empresas constroem bases de dados de dúvidas e consultas mais comuns, analisam as argüições por telefone e os interesses manifestos nas reuniões com o público. A partir deste material são desenvolvidos os conteúdos e disposições das informações no Website. Os usuários têm grande influência no conteúdo e profundidade dos materiais impressos, de jornalismo empresarial, especialmente os dirigidos aos investidores não institucionais.

Nenhuma dentre as empresas entrevistadas admitiu ter uma ordem de consulta preferencial por parte dos usuários, ou mesmo, um interesse em medir isso. 
Para as empresas entrevistadas não existem barreiras significativas. Elas argumentam que o trabalho de Relações com Investidores já está culturalmente aceito como fundamental em toda a companhia, de forma que as demandas desta área para as demais são já aceitas com cooperativismo. Dentre os poucos problemas citados, estão as restrições quanto à divulgação de lançamentos e a morosidade na obtenção de acesso a informações de outras áreas.

Não há restrições para o armazenamento de informações. Há cerca de uma década de informações contábil-financeiras disponíveis on-line e ainda há possibilidade de recuperação de informações anteriores às datas iniciais expostas no website.

As companhias entrevistadas são positivas a respeito do acréscimo de valor que o trabalho de Relações com Investidores traz para as ações, para os investidores e para a imagem institucional da empresa. Porém, não houve resposta afirmativa sobre método de mensuração desta valorização.

A primeira hipótese dessa pesquisa afirmou que a Contabilidade deveria empregar o conceito de mediação, segundo a Ciência da Informação, para melhorar a sua função comunicativa. A pesquisa de campo evidenciou que as companhias abertas oferecem um serviço de mediação de informações contábil-financeiras que satisfaz o conceito definido pela Ciência da Informação, isto é, busca responder o que o usuário perguntou. Desta forma, o conceito de relevância está sendo aplicado nessa mediação institucional, como o resultado da agregação das informações contábeis e técnicas de Relações Públicas. Portanto, o acréscimo destes conceitos e práticas à função comunicativa da Contabilidade resultará em um produto informacional melhorado, confirmando, assim, a hipótese proposta.

$\mathrm{Na}$ hipótese seguinte, foi cogitado que os serviços de mediação implementados pelas empresas estariam relacionados a um aumento de valor para seus proprietários. Embora, nas entrevistas e na pesquisa junto ao grupo de 
controle, as respostas fossem positivas, confirmando o aumento de valor, a falta de metodologia para medir esse acréscimo, alegada pelos entrevistados, não permite 0 teste da hipótese, tendo como referência a pesquisa de campo. Esta confirmação, porém, foi possível com a apresentação de pesquisas nacionais e internacionais que comprovaram esse aumento de valor relacionado aos serviços informacionais das companhias abertas.

Tanto as pesquisas efetuadas nos Estados Unidos como a pesquisa brasileira, realizada pelo Instituto Brasileiro de Relações com investidores (IBRI), juntamente com a Fundação Instituto de Pesquisas Contábeis e Atuariais (FIPECAFI), reforçam a opinião obtida nas entrevistas sobre a importância da tecnologia para a execução dos serviços da área de relações com investidores. A primeira e a principal fonte de busca de informação sobre a empresa para os usuários é o website. Isso confirma a hipótese de que a tecnologia utilizada é determinante para estes serviços de mediação.

Considerando os atributos da comunicação contábil, as denominadas "características qualitativas", cunhadas pelas pesquisas dessa área, constituem um excelente conjunto de parâmetros para a elaboração e a adequação de informações, aplicável em outros domínios de conhecimento, não somente para informações técnicas. A "compreensibilidade", primeira característica listada, enfoca o usuário, salientando que o caráter especializado da informação não deve inibir a divulgação de eventos mais complexos. A característica seguinte, "relevância", apresenta o conceito contábil dessa palavra: relaciona a informação à decisão. Finalmente, a "confiabilidade" aparece como resultante da observação de outros atributos, como precisão, essencialidade, imparcialidade e cautela.

A Ciência da Informação tem, nesse conjunto de "características qualitativas das demonstrações contábeis", um referencial desenvolvido a partir de uma especialidade, que pode ser empregado para a melhoria da produção informacional generalizadamente. 
A congregação de domínios de conhecimento praticada pelas companhias abertas, por meio de uma interface de comunicação que se opera entre os usuários externos desse serviço e os subsistemas que compõem essas empresas, foi de grande interesse para a pesquisa.

Os resultados obtidos com este trabalho interdisciplinar envolvendo a Contabilidade e a Ciência da Informação revelaram a presença de teorias vindas de outras áreas de estudo da Comunicação, especialmente de Relações Públicas. Do estudo de usuários, trazido da Ciência da Informação, houve desdobramentos como a segmentação e a comunicação organizacional integrada, provenientes de Relações Públicas e, finalmente, as possibilidades de uso das características qualitativas das demonstrações contábeis. Confirma-se com este trabalho, que a pesquisa interdisciplinar contribui para fazer avançar o conhecimento sobre os fenômenos sociais. 


\section{Referências Bibliográficas}

AQUINO, Mirian de Albuquerque (Org.). O campo da Ciência da Informação. João Pessoa: Editora Universitária, 2002.

BARRETO, Aldo de Albuquerque. Transferência da informação para o conhecimento. In: $\boldsymbol{O}$ Campo da Ciência da Informação. João Pessoa: Editora Universitária, 2002.

BELKIN, N.J. Cognitive models and information transfer. Social Science Information Studies. $\mathrm{n}^{\circ} .4$, p. 111-129, 1984.

BERLO, David K. O processo da comunicação. São Paulo: Martins Fontes, 1999

BLAIR, D.C. Information Retrieval and philosophy of language. The Computer Jornal, v.35, $\mathrm{n}^{\circ} 3$, p. 200-207, 1992.

BORKO, H. Information science: What is this? American Documentation. V.19, $\mathrm{n}^{\circ}$. 1, p.35, jan. 1968.

BOTTENTUIT, Aldinar Martins. Cidadania Digital: responsabilidade social em um mundo conectado e em rede. In: CASTRO, César Augusto (Org.). Ciência da Informação e Biblioteconomia: múltiplos discursos. São Luíz: Edufma, Edfama, 2002.

BROWN, Lawrence D. CAYLOR, Marcus L. Corporate Governance and Firm Valuation. Disponível em: <SSRN: http://ssrn.com/abstract=754484>. Acesso em 20.12.2005.

CANARY, Glenn. São Paulo. RI n. 11, p.9, Jan. 1999.

CAPURRO, Rafael. Epistemology of information Science. Disponível em: <http://www.capurro.de/trita.htm>. Acesso em: 2005

CASTRO, César Augusto (Org.). Ciência da Informação e Biblioteconomia: múltiplos discursos. São Luís: Edfama e Edufma, 2002.

CAVALCANTE, Francisco; MISUMI, Jorge Yoshio. Mercado de Capitais. Rio de Janeiro: Campus, 2003.

CHANLAT, J.F. coord. 0 indivíduo nas organizações:dimensões esquecidas. São Paulo: Atlas, 1992.

CINTRA, A.M.M. ; TÁLAMO, M.F.G.M.; LARA, M.L.G.; KOBASHI, N.Y. Para entender as linguagens documentárias. São Paulo: Polis; APB, 1994.

D'ÁURIA, Francisco. Primeiros princípios de contabilidade pura. São Paulo: Editora Nacional, 1959

EPSTEIN, Isaac. Teoria da Informação. $2^{a}$ ed. São Paulo: Ática, 1988.

FARIA, Valter. Curso de introdução ao mercado de capitais. in Por que ser uma companhia aberta? São Paulo, junho de 2004.

FERNEDA, Edberto. Recuperação da informação: análise sobre a contribuição da Ciência da Computação para a Ciência da Informação. Tese ECA, São Paulo: 2003

FIGUEIREDO, N.M. Da necessidade de promover o uso da informação. Ciência da Informção, v.16, $\mathrm{n}^{\circ}$ 1, p.75-79, 1987. 
FUJINO, A. Serviços de informação no processo de cooperação universidade empresa: proposta de um modelo de mediação institucional para micro e pequena empresa. Tese (Doutorado em Biblioteconomia) - Escola de Comunicação e Artes. São Paulo: Universidade de São Paulo, 2000.

FUJINO, A. Serviços de informação tecnológica para empresas industriais: subsídio para planejamento a partir de estudo de usuários. Dissertação (Mestrado em Biblioteconomia) - Escola de Comunicação e Artes. São Paulo: Universidade de São Paulo, 1993.

GÓMEZ, Maria Nélida González de. Dos estudos sociais da informação aos estudos do social desde o ponto de vista da informação. In: O Campo da Ciência da Informação. João Pessoa: Editora Universitária, 2002.

GREGORY, J.Jonas, BLANCHET, Jeannot. Assessing quality of financial reporting Accounting Horizons. vol. 14, $\mathrm{n}^{\circ}$ 1, Set. 2000.

GREGORY, J.Jonas, YOUNG, Stephen J. Bringing the gap: who can bring a user focus to business reporting? Accounting Horizons. vol.12, n¹, Jun. 1998.

GUAGLIARDI, José Rafael. A evidenciação de informações em companhias abertas um estudo exploratório. Tese (Doutorado em Controladoria e Contabilidade) Faculdade de Economia, Administração e Contabilidade. São Paulo: Universidade de São Paulo, 1987.

GUERREIRO, Reinaldo. Modelo conceitual de sistema de informação de gestão econômica: uma contribuição à teoria da comunicação da contabilidade. Tese (Doutorado em Controladoria e Contabilidade) - Faculdade de Economia, Administração e Contabilidade. São Paulo: Universidade de São Paulo, 1989.

HENDRIKSEN, Eldon S. VAN BREDA, Michael F. Teoria da Contabilidade. $5^{a}$ edição. São Paulo: Atlas, 1999.

INTERNATIONAL ACCOUNTING STANDARDS BOARD (IASB). Normas Internacionais de Contabilidade 2001. São Paulo: Ibracon - Instituto dos Auditores Independentes do Brasil: 2001.

INSTITUTO BRASILEIRO DE RELAÇÕES COM INVESTIDORES (IBRI). Disponível em: <http://www.ibri.com.br>. Acesso de 2003 a 2006.

INGWERSEN, Peter. Information retrieval in context. London: Taylor Graham, 1992

IR GLOBAL RANKINGS. Disponível em: <http://www.irglobalrankings.com/irglobal/html/>. Acesso em: 2005.

IUDÍCIBUS, Sérgio de et Alli. Contabilidade Introdutória. 9a ed. São Paulo. Atlas, 1998.

KOBASHI, Nair Yumiko. A elaboração de informações documentárias: em busca de uma metodologia. Tese (Doutorado em Biblioteconomia) - Escola de Comunicação e Artes. São Paulo: Universidade de São Paulo, 1994.

KRIPPENDORFF, Klaus. Metodologia de análisis de contenido. Barcelona (Espanha): Ediciones Paidós, 1990.

KUNSCH, Margarida Maria Krohling. Planejamento de Relações Públicas na Comunicação Integrada. São Paulo: Summus Editorial, 2002. 
LARA, Marilda L.G.de. Conceitos terminológicos para a construção de linguagens documentárias. São Paulo: ECA/USP, artigo preliminar de uso didático. 2003.

LARA, Marilda L.G.de. Elementos de Terminologia. São Paulo: ECA/USP, apostila de uso didático. 2003.

LUSTOSA, Elcias. O texto da notícia. Brasília: Editora UNB, 1996

MAHONEY, William F. Relações com Investidores. Rio de Janeiro: IMF Editora, 1997.

MARCHIORI, Patrícia Zeni. O campo de atividades, a ciência e o espaço da gestão da informação. In: CASTRO, César Augusto (Org.). Ciência da Informação e Biblioteconomia: múltiplos discursos. São Luíz: Edufma, Edfama, 2002.

MARION, José C. REIS, Arnaldo (coord). Mudanças nas demonstrações contábeis. São Paulo: Saraiva, 2003.

MARION, José Carlos. Contabilidade Empresarial. 9a.ed. São Paulo: Atlas, 2005.

MARQUES, Paulo Renato. RI. São Paulo, n ${ }^{\circ}$ 19, p.12, set. 1999.

MARTELETO, Regina Maria. Conhecimento e sociedade: pressupostos da antropologia da informação. In: AQUINO, Mirian de Albuquerque (Org.). O campo da Ciência da Informação. João Pessoa: Editora Universitária, 2002.

MZ CONSULTING. Disponível em: <http://www.mzconsulting.com.br>. Acesso em: 2005.

LARSON, Kermit D.; JENSEN, Tilly; CARROLL, Ray; LÉGARÉ, Michel; PERRON, Guy. Initiation à la comptabilité générale. vol.1, 7a. ed. Canadá, Montrréal: Chenelière McGraw-Hill, 2003.

LE COADIC, Yves-François. A Ciência da Informação. Brasília: Lemos Informação e comunicação Itda, 1996.

MARCHIORI, Patrícia Zeni. O campo de atividades, a ciência e o espaço da gestão da informação. In: CASTRO, César Augusto (org.). Ciência da Informação e Biblioteconomia: múltiplos discursos. São Luiís: Edfama e Edufma, 2002.

LUHMANN, Niklas. Confianza. Barcelona: Editorial Anthropos, 1996.

NIRI. National Institute of Investor Relations. Disponível em: <http//www.niri.org>. Acesso em: 2005.

OLIVEIRA, Luiz C.V., CAVALCANTE, Elmano P. Um modelo conceitual para a avaliação de inteligência empresarial nas organizações. In: AQUINO, Mirian de Albuquerque (Org.). O campo da Ciência da Informação. João Pessoa: Editora Universitária, 2002.

PARENTE, Norma. Governança Corporativa. Revista de Direito Bancário, do mercado de capitais e da arbitragem. São Paulo: Revista dos Tribunais, 2002, ano 5, no 15, 81-90, Janeiro-Março.

PIMENTA, Márcia Teresa da Rocha. O profissional da informação e as novas mediações no atendimento ao cliente. In: CASTRO, César Augusto (org.). Ciência da Informação e Biblioteconomia: múltiplos discursos. São Luiís: Edfama e Edufma, 2002

PINTO, Virgínia Bentes. Representação do conhecimento em Ciência da Informação através dos esquemas de tarefas (ETAF). In: AQUINO, Mirian de Albuquerque (Org.). 0 campo da Ciência da Informação. João Pessoa: Editora Universitária, 2002.

PORAT, Marc Uri. The information economy: definition and measurement. Washington: U.S.Department of Commerce, 1977. 
QUEIROZ, Antônio Diomário de. Integração dos sistemas de produção e finanças: demonstrativos e análises dos fluxos de fundos. 1988. Trabalho submetido à comissão examinadora do concurso público na carreira do magistério superior. Classe: Professor Titular. Área de Conhecimento: Gerência de Produção. Programa de PósGraduação em Engenharia da Produção, UFSC, Florianópolis.

SELLTIZ, WRIGHTSMAN e COOK.(org.) Métodos de pesquisa nas relações sociais. vol.2. São Paulo: EPU: 1987

SERRA NEGRA, Carlos Alberto; SERRA NEGRA, Elisabete Marinho. Manual de trabalhos monográficos de graduação, especialização, mestrado e doutorado. São Paulo: Atlas, 2003.

SFEZ, Lucien. Crítica da Comunicação. São Paulo: Loyola, 1994

SILVA, Benedito Gonçalves da. O sistema de informação contábil sob a ótica da teoria da comunicação. São Paulo, Dissertação FEA/USP, 1994.

SILVA, Wesley Mendes da, ALVES, Luiz Alberto de Lira. "The Voluntary Disclosure of Financial Information on the Internet and the Firm Value Effect in Companies across Latin America"., 13th International Symposium on Ethics, Business and Society. Universidad Navarra Barcelona, Janeiro 2004.

TAVARES, Olga. Comunicação e informação: caminhos de conexão. In: AQUINO, Mirian de Albuquerque (Org.). O campo da Ciência da Informação. João Pessoa: Editora Universitária, 2002.

TRIVIÑOS, Augusto N. S. Introdução à pesquisa em Ciências Sociais. São Paulo: Atlas, 1987.

YIN, Robert. Estudo de Caso - planejamento e métodos. 2a ed. Porto Alegre: Bookman, 2001.

ZABISKY, Rodolfo. RI. São Paulo, p. 12-13. Abr. 2000. 


\section{Anexos}

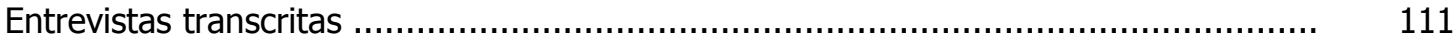

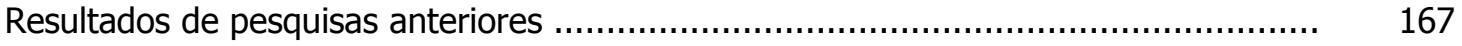

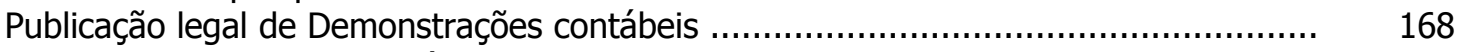

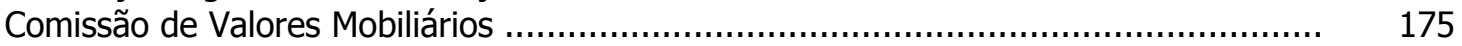

Pareceres e instruções da CVM ...................................................................... 180

Cartilha da Associação Nacional de Investidores do Mercado de Capitais - ANIMEC ..... 188 


\section{Entrevistas transcritas}

\section{Banco Bradesco S.A.}

Identificação

1. Nome, cargo, formação, breve histórico

2. Equipe: tamanho, principais funções. Essas funções são compartilhadas? Ou há divisão de trabalhos, etapas, clientes etc?

Entrevistados:

Jean Felipe Leroy - Superintendente Executivo

Edna R. Santos - Analista de RI

A equipe: 5 pessoas - $O$ superintendente executivo, formado em Administração com pós graduação; uma secretária, dois analistas de RI, também formados em Administração de empresas com MBA em Controladoria e um encarregado do website de RI do Banco.

As funções são compartilhadas, de forma que há revezamento em períodos de férias. 0 trabalho é realizado em equipe, embora haja uma divisão de tarefas.

3. Quem são os usuários das informações?

Olha, nós temos 3 grandes usuários. São os investidores, propriamente ditos,... nós temos os analistas de mercado e os administradores de carteira. Basicamente é esse o foco que a gente trabalha.

4. Como a instituição os identifica? Faz pesquisa própria? Utiliza dados de outras fontes? Quais?

Bom, a parte de investidor estrangeiro, nós temos uma relação de quem são. Nós temos também no departamento de controle e custódia, quem são os investidores. Só que o tratamento é o mesmo para todos.

Então vocês identificaram 3 grupos principais. Isso vocês mesmo identificaram, ou vocês contrataram uma empresa para traçar o perfil de quem consulta?

Não. A parte de investidores estrangeiros, como nós temos um banco custodiante, que é o Citibank, ele dá a relação de usuários com cadastro...

E o nacional é mais pela consulta do site? 
Site não. São bases de dados...

Então o próprio banco tem a base de dados, e através dessa base ele formou essa divisão em três grupos principais...

Não, na verdade isso o é na parte de investidor, porque nosso cliente principal para o banco é o investidor, que está comprando as nossas ações, mas por um outro lado, o analista, ele está dando recomendação do banco, então a gente precisa atender, precisa ter material disponível para ele, e assim bem como os administradores de carteira, então...

E esse pessoal entra mais em contato por telefone, ou email? Tem uma tendência? Não, é todo tipo.

5. Como são classificados (tipos de investidor) Institucional ou investidor pessoa física? IsSO

6. Tipos de informações: há produtos customizados? Mesmo com a democracia da divulgação, há explicações ou formas diferenciadas de mediação? A linguagem técnica é de conhecimento obrigatório?

Não, não tem diferenciação. Porque é assim, tudo que o Banco procura fazer, é para melhor rentabilizá-lo. Então, você não pode dar um tratamento diferente.

As perguntas chegam para você, mais ou menos, no mesmo nível técnico?

Não. Nós temos aqui aqueles investidores pessoa-física, que já têm uma noção, que conhecem o mercado, que sabem como funciona, então às vezes ele tem uma dúvida pontual, uma coisa ou outra, por exemplo, nós tivemos uma bonificação agora em 23 de novembro, aí ele achava...só que é assim: ao mesmo tempo que dobrou a quantidade de ações que o cliente tinha, o preço reduziu, isso foi uma ação que o banco teve para poder tornar as ações mais atrativas, elas estavam sendo negociadas num patamar de 118, caiu pela metade o preço, para se tornar mais atrativas. Muitas pessoas acharam que, "é eu vou ganhar o dobro das ações", e achou que o valor ia dobrar também. Na verdade não. Ele manteve a mesma posição. Então existe esse tipo de questionamento.

aí gera muita ligação e dúvida ...

Gera muita dúvida...

E esse pessoal que é pessoa física, eles preferem ligar, ou preferem o site(?). Tem alguma preferência? 
Depende muito, porque veja você, às vezes a pessoa não tem...olha, ainda existe na era do computador, ela ainda não tem aquela familiaridade... prefere pegar o telefone e ligar, às vezes prefere ouvir da pessoa, e tem aqueles que escrevem. Qualquer dúvida, seja ela por email ou telefone, a gente procura saná-la.

Processo de geração de informação

7. Como ocorre o processo: análise diagnóstico da situação, planejamento, ação, feedback, mensuração (e reinício)? Quais as informações e formas de captação de informação de cada fase? Existe algum problema ou curiosidade em alguma fase?

8. Como é feito o armazenamento das informações? (organização para acesso e recuperação)

É...Nós não somos donos de informação nenhuma. Cada área do banco tem a sua informação. Então nesse momento a gente tem muito contato com a parte de contabilidade do banco onde a gente monta os modelos com "o que é que eu quero mostrar para o mercado?". Então eu tenho isso, aí eu vou na contabilidade, busco essas informações, e aí a gente passa. Só que é assim, tem que ter um conhecimento total do que está acontecendo, porque às vezes o analista, além daquilo que está ali, o analista quer um detalhe um pouco maior, aí você tem que está preparado para responder. Agora, por um outro lado, todo material que a contabilidade faz ele fica disponibilizado no site - que seria o book, não é? Este aqui é o Book nosso de setembro. Quando você olha lá, desde 2000, nós temos esse material do book no nosso site. Então, a partir de 2000, você consegue acessar todo o material...

E vocês substituem, ou vão só acumulando?

Não, vamos acumulando...

Então é um banco de dados que vai... que você pode consultar retroativo até 2000?

$E_{\text {, }}$ mas, por exemplo, tem casos de... Eu tive um caso uns tempos atrás aí, que a pessoa era um estudante também, precisava fazer um trabalho para faculdade e queria informações do banco. Como o nosso site só era desde 2000 e ele precisava desde 95, eu acho que ele estava fazendo um estudo sobre o Plano Real, aí ele me solicitou. Nós temos o material impresso, nós escaneamos e mandamos por email para ele.

Então antes de 2000 é possível consultar, só não está no nosso site... Isso.

Meios de divulgação 
9. Quais os canais que a instituição se utiliza? Site, Serviços terceirizados, jornais, Bovespa CVM, (mais algum?)

11. Qual a ordem de preferência do usuário? Como é medida? O que o Sr. pensa da obrigação legal de publicação em jornais?

Aí, tem uma relação, tem uma relação deles aqui, olha, divulgação no site, publicações em jornais, na Bovespa, na CVM, na SEC, na NYSE, na Latibex utilização de serviços terceirizados, publicação de Relatórios Anuais, Relatórios Sociais, Relatórios de Análises Econômicas e Financeiras, publicações trimestrais do jornal "Acionista sempre em dia" e Revista Bradesco, conference calls via telefone e via Web, e ainda participações em conferências, palestras, e road-shows no Brasil e no exterior... É bastante!...

10. Como ocorre a mediação? O nível de explicação, de esclarecimento é igual ou não?

A CVM, Bovespa, você só manda os números, jornal você só publica, no nosso jornal "sempre em dia" e relatórios nossos, a gente dá um destaque maior no que foi importante naquele semestre no resultado do banco. E... tem o relatório anual, o relatório especial, então, todos têm o informe de como o banco está interagindo...

Então a parte técnica, a parte do governo, vai, vamos dizer, um número seco. É aquilo ali, eles já entendem... E a outra forma de interação com o público, com as organizações, ongs e tudo?

A gente pode dizer que tem uma explicação melhor mesmo do que é o banco, do que o banco vem fazendo, agora no banco foi criada de responsabilidade sócio-ambiental, então ele coloca tudo, as ações que ele está fazendo nesse sentido, então, assim, é bem detalhado mesmo...

tem um pouco mais de divulgação institucional, não é?

Isso. Por exemplo, nós estamos analisando o relatório especial que nós vamos soltar este ano, a gente coloca assim... olha, com os investimentos que estão sendo feitos nessa área, ou tem um cartão de crédito, ou tem uma capitalização voltada para o meio ambiente, 0 investimento foi tanto, e isso foi feito com que tantas árvores foram plantadas... Nós estamos fazendo reciclagem de papel... Então é assim, o banco procura dar esse... Esse enfoque, nas ações que ele está fazendo. E tem o relatório de análise econômico-financeira que, para você ver são duzentas e tantas páginas, ele tem balanço, ele explica linha a linha da demonstração de resultados, explica as contas de balanço propriamente ditas e é bem 
explicadinho, é bem detalhado. às vezes as pessoas ligam perguntando o que não conseguem achar, de tão grande que é.

E esse mais explicado, mais detalhado, vocês enviam para quem?

Na verdade, ele fica no site...Porém, nós temos o relatório impresso, que a gente manda imprimir, e às vezes vem investidor aqui, quando a gente os recebe, que não tem, a gente, se ele quiser a gente entrega.

11. Qual a ordem de preferência do usuário? Como é medida? Existe alguma preferência do usuário de vocês? Por exemplo... existe alguma medida... a maioria dos nossos investidores preferem consulta ao site...ou tantos por cento preferem ligar, por telefone ?

Não, não temos essa medida. Claro que todo mundo hoje prefere consultar a mídia. No caso dele não encontrar o que ele está procurando, ou até encontra mas não entende aí ele liga. Entende? É o que eu estou te falando, às vezes a pessoa liga: "ah, eu preciso de um detalhamento de receitas de serviços, eu não estou achando..." aí, "...ah, é verdade, está aqui, eu nem vi". Então não tem preferência, entendeu?

\section{Ruídos e Barreiras}

12. Quais as principais barreiras internas ao trabalho de RI? As soluções são padronizadas?

13. Quais os entraves de comunicação interna mais comuns?

o que acontece aqui é o seguinte...Às vezes eu preciso, alguém me liga perguntando alguma coisa. Eu vou na área e falo, falo com o diretor e tudo: Olha, eu preciso de tal informação, que tem um analista me perguntando, e tal. Às vezes ele fala assim: Olha, eu tenho, mas eu preciso consultar meu Vice-presidente, se essa informação é passível de divulgação ou não. Isso acontece, tem coisas que eu posso falar, e coisas que eu não posso falar.

Entendo, como se diz, tem coisas que ainda não estão prontas...a forma de divulgar...

Ou mesmo embutido alguma coisa que o banco não... não quer divulgar.

E aqui vocês têm assim, uma hierarquia para dar informação? Muitas empresas que eu já observei não é todo mundo que pode falar...justamente para evitar que um fale uma coisa, um fale outra...

Na verdade, como a gente, cada um interage, um ajuda o outro, não existe isso. Porque por exemplo, quando o Jean não está, o analista liga, eu não posso falar com ele: eu não tenho essa resposta para te dar porque o Jean não está aqui. Então o que eu faço: muitas vezes eu ligo para ele e falo: Olha, tem um analista perguntando isso. E ele fala: olha, você pode 
falar isso, isso e isso. Isso às vezes o próprio vice-presidente, quando ele não está liga " $E$ aí, está tudo bem, tem muita gente perguntando...?" e tal, então a gente tem essa cobertura. E as outras áreas do Bradesco, elas passam as ligações para vocês? Ou se alguém liga pedindo uma informação, o pessoal sabe: não, isso é controlado pelo RI...

Também. Também. E nós temos um problema também... Como o nosso telefone, nosso email está no site, e já... tudo que às vezes não tem nada a ver com a área de RI cai aqui, porque é um meio deles estarem comunicando, aí a gente faz o contrário: isso aqui não é nosso, é de tal departamento, aí a gente encaminha... tem as duas situações.

Vocês costumam ter problema, de alguma área responder uma coisa que competia ao RI, ao departamento responder, e não passou uma informação completa, ou...

Olha, eu não tenho conhecimento... porque se acontecer isso... a não ser que a pessoa que pediu a informação seja ele um analista, seja ele um investidor, se ele não estiver satisfeito, eu desconheço caso dele ligar para gente para criticar... porque eu só saberia disso se ele ligasse para mim e falasse: ó, aconteceu isso...

Acontece sim às vezes na agência... foi o que aconteceu: o cliente foi na agência, e perguntou a respeito de ações e a isenção do imposto de renda nas ações, e na agência falaram para ele que tinha que pagar, aí ele ligou para mim para perguntar, mas isso aí não era no meu departamento, eu estava atendendo lá na área comercial, só que então a gente foi atrás, levantamos a legislação para ele...

14. Quais as barreiras de recuperação da informação?

Não temos...

Acréscimo de valor

15. Essa instituição mede o acréscimo de valor que o RI traz para ela na visão dos usuários? Há algum estudo?

16. A valorização financeira da empresa pode ser relacionada ao crescimento do programa do RI?

Olha, eu não sei te dizer quanto, mas eu sei te dizer que agregou muito valor, tendo em vista que você pode ver quanto era o nosso valor de mercado antes do site, e hoje, com a transparência, com tudo, o nosso valor de mercado está em torno de 32 milhões, uma coisa assim, então aumentou muito para o cliente, os analistas contam isso, publicam isso. E o analista publicando, as pessoas que às vezes ele está cuidando se interessam. 0 número de visitas cresceu bastante,... mas eu não sei te dizer, se foi 50\%, eu não sei quantificar, quantificar eu não sei, mas eu sei que contribuiu bastante. 
Então a gente pode afirmar que o serviço de comunicação que o RI trouxe, ele agregou valor de mercado, valor para o usuário...

Com certeza, disso nós não temos a menor dúvida.

O que o você pensa da obrigação legal de publicação em jornais?

Olha, a gente só publica porque é obrigatório, porque a legislação exige, porque do contrário, como eu te falei, está no site, não é? Apesar da gente conhecer muita gente que não tem acesso. Porém, a gente distribui várias revistas com resultado trimestralmente... eu entendo assim, eu gostaria que você também perguntasse para o Jean, para que ele colocar a opinião dele: eu vejo dessa forma, porque hoje a gente tem muitas maneiras, e você vê lá na nossa recepção, tem várias revistas falando do banco, dos resultados, dos números...

E outra coisa que eu preciso saber: vocês têm uma padronização...do trabalho de RI, vem uma pergunta, vem uma solicitação... ah bom, isso aí a gente retorna assim, um passo - a passo para responder?

Olha, a gente tem respostas padrões para perguntas padrões. Quando a pergunta é a mesma e a gente já tem a resposta, a gente coloca, agora depende de cada, de cada pergunta... Mas nem todo mundo pergunta a mesma coisa, não é? O que acontece, assim, por exemplo, da bonificação, teve vários questionamentos, então, como era tudo por email, o que respondeu para um vale para o outro, então nesse caso é válido, mas na parte de números daqui, não.

Então seria assim: quando tem algum evento que gera uma dúvida padrão, alguma coisa nova, aí vocês acabam montando uma resposta que atenda...

Exatamente, isso porque na verdade as questões, assim... escritas são muito poucas. Nós damos muita explicação por telefone, mas a maioria dessas perguntas já está tudo na cabeça, então como é falado, então...

Comentários gerais do superintendente executivo Jean Felipe Leroy

No começo do ano, nosso trabalho é ainda mais sobrecarregado, porque muitos usuários fazem contato, vêm visitar, tem conferências, porque eles querem calibrar a carteira deles para o ano, então querem entender bem o que está acontecendo com a empresa, cenário macro, etc. Aí juntou isso, juntou meu casamento, juntou a mudança de chefe, essa semana 
eu passei a ter um novo chefe, e, além disso, daqui a 12 dias a gente divulga resultado do ano... então está uma correria desenfreada, lamento muito, eu gostaria de ter participado desde o início mas eu fiquei impedido por causa de uma série de coisas que... por causa do business plan do ano, eu acabei agregando uma nova área desde o ano passado, desde final do ano passado, desde praticamente setembro, setembro/outubro, que é a área de responsabilidade sócio-ambiental. Então tem a área de relações com investidores, que basicamente vai está tratando com analistas e investidores, falando sobre o banco, basicamente investidores institucionais, mas também atende pessoa física, porque também o mercado de capitais cresceu, e muita gente está vendo ação como sendo uma boa opção de investimento. Tem a parte de responsabilidade sócio-ambiental, que aí envolve desde mostrar o que é que as empresas fazem... você imagina, uma empresa que deu 4 bilhões de reais de resultado em 9 meses no ano passado, de alguma maneira tem que mostrar o que é que faz pela sociedade também. Então é um caminho de ida e volta, e pelo fato das empresas e das pessoas físicas também indagarem sobre o que é que essa empresa faz, então achou-se natural da comunicação, sendo feita pelo RI, ser agregada também a parte de responsabilidade sócio-ambiental, que aí você teria o todo. Além disso, você tem uma proliferação de ONGs, todo mundo quer testar, analisar, perguntar, indagar, e aí você precisa fazer um trabalho bem profissional. No nosso caso, a gente tem muito histórico para contar porque, já começa, de que em 56, o banco criou, o Amador Aguiar na época criou uma fundação para dar educação a brasileiros... essa fundação já formou 600.000 brasileiros. Essa fundação hoje tem cento e tantos mil alunos, mas 600 mil já foram formados. Dentre esses 600 mil existem também diretores de empresas, gerentes... muita gente que se não tivesse tido acesso através da fundação, com certeza não seria nem gerente, não seria diretor. Então... são casos bem interessantes que a gente precisa contar, e tem também toda a parte de envolvimento em patrocínio em esporte, parte cultural, Picasso que a gente trouxe lá na Oca, o esporte, o programa para inserção. Tem toda a parte muito interessante que é banco postal, que é a utilização da rede de 5.500 agências do Correio para vender também produtos de banco, que são produtos do Bradesco. Então, nesses, basicamente, 3 anos efetivos nós já trouxemos 4,2 milhões de clientes do Bradesco, clientes que em sua maioria não eram bancarizados, muita gente que nunca tinha, nunca teve conta em banco. Então são pessoas que para eles é tudo novo, não é? E não só pessoas que para eles é tudo novo, como a venda, a coordenação é feita pelos Correios, em 1.800 praças não tem banco além do Bradesco, e em muitos Correios o próprio cara do Correio não tem conta em banco, então, é que nem o cara que não dirige carro vender carro. Então é uma coisa assim um pouco complicada. Mas de qualquer maneira é um 
trabalho que é complementar ao trabalho do RI. Você teve com a Edna aí, acho que uma hora quase. Eu pedi para ela adiantar, porque que tem muito assunto que acho que ela poderia estar colaborando e também a minha limitação é de tempo, mas eu estou à sua disposição, e peço desculpas de novo pelo meu atraso.

Eu agradeço pela atenção, e tudo. Ela já me adiantou essa parte das respostas, aí ficou algumas coisinhas para te perguntar...

Tem alguma resposta dela que você, sinceramente, queria entender um pouco melhor? que você...

Sobre a obrigação de publicar em jornal.

É, isso aí é um assunto polêmico, porque lá fora você não é obrigado a publicar em jornal, e você já divulga na internet. Você poderia, na verdade, deixar na Internet: um acesso mais democratizado, não é? Porque aí acaba acontecendo que, às vezes serve de moeda... você tem que botar no Diário Oficial, que tem um custo absurdo, então já que tem que botar num jornal, você poderia botar num jornal, mas não, tem que ser no Diário Oficial mais os principais jornais, e tal, acaba sendo um custo muito alto. Até você vai ver quando sair o nosso balanço no jornal, que não é meia folha, são duas folhas, é colorido, é bem marqueteiro entre aspas, e com uma visualização mais fácil, ele é bem interessante, até para uma pessoa que não é especializada em banco, em mercado de capitais, ele está entendendo. Porque ele tenta pegar conceitos, não é? Inserção bancária... atendimento remoto... e tem muita coisa que ele traz. Não só o resultado, mas também como esse resultado foi atingido. Então o que acontece: a gente trabalha num mundo, que os investidores tem que se informar do que acontece, e até por força do que acontece e da vontade das empresas de serem cada vez mais transparentes...para você ter uma idéia, eu era do BCN, eu entrei no Bradesco em 1998, em março, estou completando agora 8 anos de casa. E quando eu entrei o balanço tinha, acho que duas ou três notas explicativas, agora o balanço tem umas 38 notas explicativas. Quer dizer, é uma coisa enorme. Então você vai botar o balanço, às vezes acaba sendo um custo enorme. Tem informação à beça. Então como é que eu vejo: você está pensando para mim pessoa física?

É.

Eu acho que é muito importante você informar, mas nem sempre o ato de informar tem que ser impresso. Pode ser também pela internet, que é a coisa mais democrática no mundo. Inclusive a gente faz a divulgação dos nossos resultados, antes das bolsas abrirem, em 3 línguas diferentes, então temos o balanço totalmente replicado em português, inglês e espanhol. Então qualquer investidor tem acesso à informação. Se fosse um jornal, aí de 
repente se questionava: porque esse jornal, e não aquele...Então o cara que é leitor do BCI... vai dizer assim "pô, mas saiu no Estadão, e não saiu no BCI"... então, bota na internet, aí quem quiser acessa... eu acho que o importante é informar, isso que é importante.

Também sobre o acréscimo de valor para o investidor, para o acionista, do trabalho do RI, existe um momento antes do trabalho do RI e um momento depois. E aí como você vê essa valorização, como refletiu nas ações do banco o trabalho de comunicação que vocês desenvolvem aqui?

São coisas muito difíceis de mensurar. A gente lida com informação. Se a gente fizer um bom trabalho eventualmente o investidor venda a ação. Aí você diz: mas como assim? É, ele pretendia vender 10 vezes mais do que vendeu. Então, em última instância, nem sempre "comprar" mostra que foi feito um bom trabalho, e "vender" mostra que o trabalho foi mal feito, porque se o trabalho foi mal feito, o investidor comprou 1 milhão de dólares de ações, era para comprar 10. Então, a gente tem uma base muito pulverizada de acionistas, nós temos hum milhão e 400 mil acionistas. É gente à beça. Existe uma grande preocupação, desde os primórdios do banco, do banco divulga todas essas informações, tanto é que, historicamente, o Bradesco sempre foi um dos primeiros a divulgar essas informações e isso não apenas como banco, como empresa, sempre ouve essa preocupação, desde a época do Amador Aguiar. Isso acabou continuando de maneira perene. Isso acabou não mudando. $O$ que eu vejo que o trabalho de relação com os investidores ele é um trabalho que está sendo muito valorizado e ajuda valorizar a empresa: eu não consigo dissociar isso, como também vejo que a recíproca é verdadeira: se o trabalho não for bem feito acaba impactando no preço da ação e no valor de mercado da empresa. Então, eu acho que é tão estratégico, que, via de regra, a área de Relações com os Investidores está ligada com o Senior Management das empresas. Antigamente era um departamento que ficava longe, até fisicamente, quando eu cheguei há 8 anos atrás estava num prédio lá longe, hoje em dia eu trabalho aqui, desço um andar, estou na diretoria. Então é importante, nós fazemos um ciclo de reuniões APIMECS, e o Bradesco é o único que traz seu presidente em seis praças. Quer dizer, na maioria dos casos são feitas muitas APIMECS, mas quem vai é o diretor financeiro, é o gerente de RI, é o diretor de RI, no nosso caso o Sr.Márcio faz questão de participar. Então isso mostra a importância que o management dá ao RI. Então a gente sabe com certeza que a gente tem colaborado muito. A gente sabe que o mercado gosta e aprecia, às vezes a gente ganha prêmios, a gente recebe elogios, quer dizer isso tudo a gente sabe. Mas é um grande desafio você fazer uma gestão perfeita. No Valor Econômico de ontem, saiu uma informação de que cada vez mais o mercado de capitais está se movimentando 
para fora das grandes cidades. Antes era o grande eixo Rio e São Paulo, agora é Rio e São Paulo, mas também praças têm movimentado muito. E aí o trabalho de RI tem que se adaptar, é que nem a música: a gente tem que está onde o povo está, então a gente tem feito mais reuniões, por exemplo, a gente não ia para Florianópolis, hoje vai para Florianópolis todo ano. Esse ano a gente provavelmente deva fazer reuniões em cidades menores, e aí eu acho que isso é muito favorável. E a gente acha que pode trazer valor para empresa, porque a gente vai está mais perto da pessoa. A utilização do site eu acho que é vital, porque o site está disponível em qualquer lugar. A pessoa está em Quixeramobim, ela entra na internet. Ela ouve a conferência telefônica, ela vê o site on-line, on-time. Então a gente realmente está usando muito o site de relação com os investidores para propagar a nossa mensagem para o mundo. Porque na verdade não é só brasileiro. Eu por exemplo hoje eu tava numa conferência eletrônica durante uma hora com um investidor da Ásia. Tem que combinar porque na hora que você acorda, que ele deita, não é? Então a gente tem combinar horário, e tal...e eu acho que a tecnologia é usada de maneira muito favorável. Não sei se eu respondi bem a sua pergunta, mas eu acho que é imprescindível manter, principalmente uma empresa grande, que tem uma grande base de acionistas, ter uma estrutura forte de relações com os investidores.

Falando nestes acionistas, eu achei interessante você comentar que o Banco tem em interesse pulverizar... Como que o banco conhece esses investidores? Vocês fazem um cadastro? Sabem o número ou o percentual de quem é um investidor individual, os institucionais?... vocês fizeram um perfil?

Não. Existe pelo fato do Bradesco fazer a custódia das suas ações. Então eu sei quais são os meus acionistas imediatamente. Eu só não sei com essa perfeição, quando o acionista compra ADRs em Nova Iorque, porque existe uma obrigatoriedade trimestral das informações dos investimentos dos investidores serem passadas para sistemas, mas é trimestral. Então eu agora estou começando a ter informações, estou fechando meu backlog de informações da minha base de ações em dezembro. Agora, se eu pego o telefone e ligo para o DAC, eu sei quais eram os meus acionistas ontem locais...e tem um grande acionista chamado Citibank, que é o depositário dos meus ADRs Você está familiar com estes termos? Então eu sei...

DAC é que eu não entendi...

DAC é departamento de ação de custódia, que é o departamento que cuida dessas custódias de ações do Bradesco e de outras empresas. O Bradesco é um dos clientes, de si mesmo. Mas a gente tem isso muito bem analisado. Aí existem os não acionistas. Tem muita gente 
que se cadastra no site e recebe informação, e para se cadastrar, ele tem que dizer o que ele é... Então eu tenho um mailing list de milhares de pessoas e eu sei o que é que eles são. Pelo menos o que eles informam que são, porque ele pode dizer que é um investidor institucional, mas é pessoa física... Na parte de investidores estrangeiros, eu analiso quem são os meus acionistas. Em base trimestral? Sim. Mas eu também analiso quem são os grandes acionistas dos outros bancos e que, eventualmente não são os meus acionistas. Então, faço um cruzamento. Em função disso, eu tento gerar reuniões, mando emails, tipo assim. "olha, eu existo" e tal. Na parte de investidores locais, ainda o mercado é muito concentrado... Quer dizer, eu sei quais são as grandes Assets e eu faço visitas a essas assets... eu sei quem são as fundações, eu visito essas fundações... e eu sei também quem é esse novo mercado de hedge fund que está começando no Brasil e muita gente me visita. Então eu tento fazer isso.

Por vocês conhecerem o perfil dos grupos de investidores, é possível prestar uma informação e desenvolver um serviço de comunicação que atenda mais?

Todas as informações que são passadas ao mercado estão no site. Então qualquer um tem acesso. A gente está tentando melhorar cada vez mais, por exemplo, a gente lançou um jornalzinho chamado "Acionista sempre em dia", que a gente manda para os acionistas que tem mais de duzentas ações do Banco... Eles recebem mais ou menos... em cada trimestre eu emito umas trinta mil cópias desse jornalzinho. Eu vou te dar uma cópia para você ver, e aí é mais direcionado a pessoa física, é num português mais inteligível - sai o resultado da empresa, como é que a gente está...etc. Mas a idéia, ela nunca pára. A gente utiliza muito a APIMEC, que é uma associação, para fazendo APIMEC's ter acesso aos associados, a gente manda também informações para a APIMEC e ela para seus associados e aí acaba divulgando mais, no final das contas, o que nós fazemos. Mas é um processo que não pára, é um processo que envolve inclusive a gente atender grupos de MBA's. A gente recebe grupos de MBA's de faculdades do mundo todo, principalmente americanos e europeus. Tem turmas de 10, 20, 30 pessoas... aí você fala sobre o Brasil, fala sobre o Banco, você está plantando, não é? Porque lá na frente essa pessoa vai ser um investidor, ou trabalhar em uma empresa que, eventualmente, queira vir para o Brasil e aí vai se lembrar do Bradesco. Você vai para Sorocaba para visitar investidores, se você fosse, o pessoal de Campinas vai perguntar porque você não foi lá... então, você tem uma massa muito grande de pessoas.

Crescente?

Crescente e cresce cada vez mais até em função do rejuvenescimento dos investidores. Quando a gente vai ver as APIMEC's a cada ano tem mais gente jovem. Antigamente nas APIMEC's você tinha o pessoal de mercado que trabalhava no mercado de capitais dos anos 
setenta... falavam do Fundo 157, se lembravam da época áurea, mas durante essas duas décadas teve muita inflação e pouca gente comprou ação. E agora, você tem muita gente jovem que está vendo listagem de empresas, taxa de juros em queda... então eles estão começando a ver que o mercado de renda variável é muito promissor. Você vê gente jovem participando das reuniões e fazendo perguntas muito procedentes, quer dizer, eles estão estudando, estão interessados e você precisa estar acompanhando esse movimento. É bem interessante isso, o mercado de capitais realmente está crescendo, tanto é que pessoa física responde por 30\% da Bovespa... Se a gente for considerar que 2 bilhões de reais são negociados por dia, tem um terço que vem de pessoa física: são 600 milhões / dia. É muito dinheiro e isso a gente tem que acompanhar. Não pode ficar parado.

\section{Banco Itaú S.A.}

Identificação

1. Nome, cargo, formação, breve histórico.

Entrevistado: Geraldo Sorares - Superintendente de Relações com Investidores do Itaú.

2. equipe: tamanho, principais funções.

Itaú: Diretor de Relações com Investidores, Superintendente de Relações com Investidores, Supervisor de Relações com Investidores, Analista Sênior de Relações com Investidores, mais 3 analistas de Relações com Investidores e uma Secretária.

Essas funções são compartilhadas? Ou há divisão de trabalhos, etapas, clientes etc?

Eu sou formado em Sociologia pela Unicamp, tenho uma pós-graduação Latu sensu pela Getúlio Vargas, ganhei uma bolsa, vim para São Paulo e fiz esse curso durante um ano. Esse curso era sobre mercado de capitais, formação de profissionais para a área de mercado de capitais, foi onde eu conheci muito bem bolsa de valores. Já conhecia alguma coisa, eu fiz dois anos de Economia na Unicamp e aí passei nesse concurso da GV que tinha provas iguais a entrar em uma Anpad, numa USP, equivalente a uma prova daquelas. Aí passei e vim aqui para São Paulo, fiz o curso da GV e depois de concluir o curso eu entrei na área de Controladoria do Banco Itaú. Com cinco anos eu era gerente de custos do Banco, durante esse período eu fiz mestrado na USP, na FEA na área de Controladoria. Neste período, tanto a área de Custos como a de Relações com Investidores começaram a despontar muito mais forte dentro da organização. Começou a se olhar muito mais "custos"...Isso eu estou falando de 97, 98,99. A questão de receitas, foram várias iniciativas em análise de receitas e começou a vir a área de custos e surgiu uma nova atividade chamada "relações com 
investidores". E, como eu estava na área de Controladoria, essa incumbência começou a vir para minha pessoa... a minha equipe, nós trabalhávamos com custos, era uma equipe muito maior do que a que tenho hoje. Eram umas dez, onze pessoas e a gente trabalhava com custos durante a semana e com relações com investidores no fim de semana. Eu trabalhava muito naquele período... e chegou uma época que o relações com investidores estava demandando muito e a área de custos estava demandando muito. Era uma época que "custos" ficou sendo uma coisa que todo mundo queria saber e a área de relações com investidores começou a encorpar demais...e aí foi decidido em 99, foram separadas as áreas, eu fui promovido a superintendente, que é meu cargo atual. Em meados de 99 que eu assumi, aí sim só trabalhar com relações com investidores, porque não era minha realidade antes de 99. Então, quer dizer, o Banco Itaú tem realmente, a partir de 99, uma área especificamente trabalhando com isso. O Banco Itaú não começou isso a partir de 99, ele já fazia antes, mas não de uma forma, digamos assim, estrategicamente pensada, todo dia fazendo, todo dia pensando nisso, em como atender melhor o investidor... quer dizer, eram feitos trabalhos específicos para demandas específicas de relações com investidores. "Ah, vamos fazer uma apresentação" - aí montar a apresentação, montar um caderno, fazer aquele material..."Ah, precisa para os Estados Unidos" - então montava-se o material para os Estados Unidos... então, você trabalhava sob demanda e o dia a dia era custos, da equipe. A partir de 99 não... então foi separado totalmente e aí sim nós tivemos uma área de relações com investidores, e aí sim que começa a trabalhar e a ter uma estratégia... e fazer um trabalho pensado no longo prazo com relações com investidores. O primeiro grande projeto nosso foi o site, quer dizer, a gente já colocava demonstrações financeiras no site do Banco... mas não tinha um site específico só de relações com investidores. Lançamos o primeiro site sete meses depois que foi constituída a área, quer dizer, foi o grande primeiro projeto e acabou virando um site extremamente premiado desde 2000 até hoje. É o site mais premiado brasileiro, não tenho dúvida nenhuma, a única diferença é que, quando a gente lançou, a gente era o top dos tops e hoje existem empresas que chegaram em num nível muito bom, algumas empresas brasileiras tem alguma competição em relação a site. Mas enfim, isso é só para você ter um breve histórico.

A equipe é uma equipe de seis pessoas, com várias formações, eu acredito muito mais no potencial, que na formação específica, não consigo contratar gente no mercado - que já entre aqui trabalhando... é uma coisa muito difícil de conseguir. Eu contrato gente que eu acredito que tenha potencial e a gente dá treinamento para essa pessoa, qualificações que possibilitem a ela trabalhar. Tem o MBA do IBRI e FIPECAI, eu tenho três funcionários que 
já fizeram o curso e isso tem a agregar para eles. Então é mais ou menos isso, para você ter uma idéia da equipe.

Essas funções são bem delimitadas ou são compartilhadas?

A nossa atividade é uma atividade que eu acredito que só pode funcionar se for compartilhada, não pode ser compartimentada. Ela tem que ser uma atividade em que as pessoas saibam o que os outros estão fazendo, conheçam e, se possível, possam cobrir aquela atividade da outra pessoa. É o seguinte, se eu tenho um funcionário que fica só fazendo site, amanhã liga um analista aqui e não tem nenhum outro funcionário, como ele vai atender esse analista? Ele só sabe fazer site...Então eu não acredito nisso. A nossa área tem muita visibilidade externa, nós participamos de congressos, reuniões, Apimec... somos a empresa que faz mais Apimec no Brasil atualmente. Esse ano a gente vai fazer doze Apimecs pelo Brasil. Então eu tenho que treinar eles suficientemente bem para que a área, 0 nome, a reputação do Banco não sofram nenhum problema, algum ruído de comunicação. Se chegar um funcionário meu num congresso desse e perguntarem a ele o que é um IPF, "Ah, qual é o IPF do Banco?" - que ele saiba se virar e responder o que é um IPF. "Ah, quanto é o B"s ratio do Banco?" - A pessoa tenha condições de responder, entendeu? Se eu tenho uma pessoa compartimentada, só fica no site, ou só fica para responder analistas...eu não acredito nisso. $O$ que nós fazemos é o seguinte, a gente discute muito em equipe aqui para a gente conseguir atribuir atividades em que você utilize o melhor potencial de cada um e, ao mesmo tempo, atividades que forcem a pessoa a aprender. Um exemplo que ficou muito claro para a gente há um ano atrás aqui, de um funcionário meu, que eu não queria passar uma atividade para ele. Mas ele brigou, fez uma reunião especial comigo... o grupo chegou a um consenso que ele não era a pessoa ideal para fazer aquele serviço. Mas ele quis fazer o serviço porque achava que ele ia crescer profissionalmente... ele insistiu tanto que a atividade foi passada para ele e ele fez o trabalho muito melhor que os dois que tinham feito antes! Quer dizer, para ele foi um desafio e ele queria aprender com isso. Hoje ele está pedindo para tirar a atividade dele. Na época da divisão da atividade, que é responder ao canal "Fale conosco" que havia no site, nós recebíamos uma média de quinze perguntas por semana. Bem, a gente recebe muito mais que isso, mas muitas não são da nossa responsabilidade, por exemplo, você manda um email para falar de um problema na sua agência... esse problema a gente vai encaminhar para a área responsável, ok? De nossa responsabilidade, a gente recebe quinze, mais ou menos, é uma média, por semana só por esse canal. Essa atividade é que já passou por dois funcionários e eu ia passar para um terceiro, só que este que está tomando conta hoje, insistiu tanto, ele fez uma campanha 
junto à equipe etc e tal, que ele pegou... e foi melhor que os outros dois. Fez um trabalho muito superior, de controle, tipo de resposta, rapidez na resposta. Ele queria a função porque ele achava que ia crescer profissionalmente, ele queria saber qual era a demanda do mercado, qual o tipo de pergunta que chegava e ele ter a capacidade de responder. E ele melhorou em tudo, melhorou no conhecimento, melhorou no português... então, isso foi muito bacana. Eu acredito mais na idéia do funcionário eclético.

3. Quem são os usuários das informações?

Olha, o foco principal é: analista de investimento, investidor e acionista. São os três grandes públicos alvos que a gente trabalha. Mas, atualmente, eu diria para você que de uns dois anos para cá, tem esse público, esse público continua... contudo, aumentou muito a demanda da mídia especializada - a mídia econômica, aumentou muito. Universitários, tese de doutorado, por exemplo... Para você ter uma idéia, a gente recebe, em média, a gente responde por mês, por volta de uns dez, quinze trabalhos desde TCC, de graduação, de mestrando... hoje, eu falei com uma menina da USP de Ribeirão que está fazendo um trabalho sobre "stock options" - dissertação de mestrado e ela ligou aqui para ter umas informações, porque ela está trabalhando com isso e está usando o Itaú como "case". Eu mandei o material para ela já hoje por email e pedi para ela mandar as perguntas por email, para a gente ir trocando emails até o momento em que a gente achar necessário realmente ter uma entrevista. A gente recebe de dez a quatorze questionários por mês de Universidades espalhadas pelo Brasil, de universitários de vários níveis: graduandos, mestrandos e doutorandos, discutindo "mercado de capitais". Todos são respondidos. Alguns demoram mais que outros, ou porque os questionários são muito complexos ou pelo momento em que a área está... a gente manda email e fala "olha, desculpa mas você me aguarde um mês aí porque estamos em correria aqui e o questionário é complicado... "peço a sua paciência" mas que a gente vai responder, vai.

É interessante o mercado de capitais, o que acontece: nós temos muita visibilidade lá fora, fazemos muitas apresentações, a gente vai fazer doze apresentações esse ano, já tem oito agendadas até o final do primeiro semestre, já foram feitas duas. E agora no final do mês tem mais seis, eu vou viajar pelo Brasil fazendo apresentações... então, você conhece muita gente, tem muita demanda, as pessoas entram em contato, pedem coisas, solicitam coisas... e todos são atendidos. Pode ser simplesmente um investidor individual de pequeno porte e ele vai ser atendido como um grande investidor... da mesma forma.

4. E como vocês os identificam? Os tipos de investidor, o Banco classifica ou separa os grupos? 
Olha, eu diria para você que temos dois grandes grupos. Tem um grupo - investidores estrangeiros, ele está lá fora e pode estar negociando tanto na Bolsa de Nova Iorque como na Bovespa. Aqui é $A D R$, nós temos ADR lançadas no exterior, nível dois, tudo bem? E Bovespa, eu tenho anexo 4. O estrangeiro hoje, ele tem por volta de 33\% do meu "free float", que é mais ou menos a metade do meu capital social. Então, um terço mais ou menos está na mão de estrangeiros, ou via ADR ou via Anexo 4. Lá fora tem um terço, no Brasil tem dois terços. Esse daqui [quadro com investidores externos] chama-se investidor institucional, ta? O Itaú é um Banco que não tem investidor de varejo lá fora. Não estou trabalhando com pequeno acionista lá fora. Eu te diria que é muita pretensão a gente querer trabalhar com o varejo norte-americano, porque as empresas que têm ADR e têm uma inserção junto ao varejo americano são empresas que tem algum negócio lá dentro, e um negócio visível. Por exemplo, uma Cemex, Cimentos do México, que tem uma operação dentro dos Estados Unidos, comprou uma cimenteira dentro dos Estados Unidos - para eles é relativamente fácil atingir o público do varejo, você fala "eu tenho uma fábrica ali". Para nós, é muita pretensão querer chegar a esse mercado, eles não tem nenhuma idéia do que é o Banco Itaú, eles mal têm idéia do que é Brasil... Esquece! Todo mundo fala, você tem que atingir o varejo norte-americano, mas para quê? Envolve gastar muito dinheiro... eu acho que tem muita empresa que fala isso, mas é da boca para fora, vai gastar muito e não vai conseguir nada. Então, o estrangeiro, principalmente o norte-americano, nós temos na Europa, Estados Unidos etc.

E outro público que nós temos, está no Brasil, é o investidor nacional. Com relação ao investidor brasileiro, eu tenho a custódia do Banco, o Banco custodia suas próprias ações. Para todo mundo que tem a custódia do Banco, eu sei exatamente a qualificação, a qualidade, o tamanho, prazo, quanto tempo ele tem investido em ações do Banco, enfim... eu consigo estratificar isso da forma que eu quiser. Hoje a gente fez um almoço com 21 acionistas e a gente escolheu simplesmente o seguinte: "eu quero acima de 10 anos de ações, entre 35 e 55 anos de idade... enfim, esse público [investidores externos] e esse público da Bovespa, eu consigo estratificar da forma que eu quiser. Porque é um público que está custodiado dentro de mim.

Então, o Banco tem um cadastro? No sistema?

Isso, na custódia. Vamos supor, quando eu fui escolher o público alvo, para fazer esse almoço de ontem, como eu falei: vamos pegar os que já têm ações há mais de dez anos, têm entre trinta e cinco e cinqüenta e cinco anos de idade, que morem em São Paulo... enfim, fizemos um grupo de pessoas. Desse grupo, nós convidamos e vieram 21 ontem. $A$ 
gente queria um grupo de mais ou menos trinta, mas vieram 21. Então, eu "brinco" do jeito que eu quiser com essa informação ...Qual é o grupo que eu "brinco"? O que está na minha custódia: todo esse público brasileiro, mais o estrangeiro do Anexo 4.

A mais, o que estiver na ADR tem um problema: nos Estados Unidos, não só nos Estados Unidos, mas em Londres, Edimburgo, enfim, no exterior em geral, eles não te dão cadastro. Não existe um cadastro, é diferente a metodologia lá da metodologia daqui. Aqui, você fala o seguinte: "eu tenho custódia, não é?" Então, tudo o que estiver na custódia, eu tenho informação: os dados todos - telefone, email, endereço, ta tudo "bonitinho" lá. Evidentemente, tem problemas, do tipo: cadastro desatualizado etc e tal, mas teoricamente, eu tenho todo o cadastro. Como todo mundo que utiliza o Itaú como custodiante também tem esse cadastro perfeito. $E$ tem mais um detalhe, no Brasil, você tem vários custodiantes: Bradesco, Itaú, a própria Bolsa de valores. Se você quiser, você custodiar tua ação numa corretora, você pode, na verdade você não está custodiada naquela corretora, você está custodiada na CBLC (Companhia Brasileira de Liquidação e Custódia), que é da Bovespa. Eles falam "corretora", mas não é, na verdade, está na custódia da CBLC. Pois é, a CBLC todo dia faz a movimentação. Quem fica na CBLC normalmente? São pessoas que operam muito rápido, pessoas que não querem ficar um ano com a ação, então, ela compra e na primeira oportunidade, vende. Porque na CBLC é fácil de fazer operações. Já enquanto você está numa custódia, você tem que comprovar quem é você etc. tem que passar por alguns passos a mais, pelo controle, para não ter fraude, para não ter nenhum problema. A CBLC passa, todo dia à noite para a empresa que custodia a ação de uma companhia aberta, a movimentação dos acionistas. A empresa custodiante sabe, e passa os dados para a companhia aberta, que pode ter todas as informações sobre os acionistas. Então você tem todas as informações na custódia, as únicas que não temos, são as do exterior, por causa de regras. No exterior, tem a seguinte questão, o Banco custodiante, vou te dar um exemplo, o maior banco custodiante dos Estados Unidos é o Bank of New York, que a gente chama de Bony. Ele deveria, pela nossa "cabeça" ser igual ao Itaú aqui, ter cadastros direitinho - não tem! Nos Estados Unidos é assim, você pode ir a uma corretora, comprar ação de uma empresa e falar "eu não quero que você me registre no custodiante" - mas aí você está falando com a corretora, nem a Bolsa de Valores sabe quem é a pessoa. No Brasil, é diferente, quando uma pessoa falar para você que está custodiada na corretora, ela está na CBLC, as corretoras não tem custódia. Então existe um lugar onde está a informação daquela pessoa que é passada para a empresa custodiante. Nos Estados Unidos, não, se você for à corretora e disser que não quer que sua informação seja passada, só quem sabe quem comprou é a corretora. Bom, como é que a gente consegue descobrir informação lá 
fora de quem está comprando e quem está vendendo o nosso? Só consegue de um público de investidor institucional. Nos Estados Unidos é obrigatório aos fundos que tem patrimônio acima de US\$100 millhões, divulgar trimestralmente a movimentação deles. Por exemplo um fundo de Hong Kong tem operação nos Estados Unidos, ele vai ter que informar para a SEC, ou o Citibank tem um fundo na Alemanha, mas como o Citi é norte-americano, ele vai ter também que informar a SEC. É um relatório chamado $13 F$, que é passado trimestralmente para a SEC e a SEC coloca isso num banco de dados. Nós aqui capturamos as informações desse grupo de investidor institucional e conseguimos descobrir, através dessa informação, como está a movimentação das ações. O último cálculo que eu fiz, por volta de $75 \%$ do que eu tenho lá fora, eu consigo identificar através do $13 F, 25 \%$ eu não consigo identificar. E aí você trabalha, você consegue fazer táticas de relacionamento e de comunicação com todos esses públicos de uma forma diferente. Então para cada público alvo, a gente trabalha de um jeito diferente...

É isso que eu ia te perguntar agora...

Segmentação?

Tipos de informação.

6. Tipos de informações: há produtos customizados? Mesmo com a democracia da divulgação, há explicações ou formas diferenciadas de mediação? A linguagem técnica é de conhecimento obrigatório?

Então por exemplo, isso aqui é uma peça que nós desenvolvemos, chama-se "Itaú em Foco". É uma peça didática, ela vai para os acionistas, nós fizemos uma pesquisa com dois grupos - focos, nós sentamos com eles... fui eu que "bolei" isso, fui lá, conversei com eles, a gente queria saber o seguinte "nós estamos nos comunicando bem com vocês?" E chegamos nisso, nessa peça. Eles discutiram a peça conosco. Por exemplo, eu tinha uma idéia e eu sugeri para eles sobre a segunda página, "vamos fazer uma entrevista com um executivo do Banco". Mas eles foram totalmente contra, ótimo, é a opinião deles. Eu achava legal, eles acharam péssimo, tá bom...A peça foi construída com base em discussões com eles. Outro exemplo que eu não coloquei e eles sugeriram, foi o "você sabia" - que é, dentro do jornalzinho, ter uma curiosidade do Banco, alguma historinha do Banco. Sabe por quê? Eles são acionistas antigos, eles querem ficar no Banco, participar e conhecer melhor o Banco, inclusive para falar para os amigos... "você sabia que o nome Itaú significa 'pedra preta' em Tupiguarani?" Para eles isso é importante. O "você sabia" foi construído por eles. A idéia do "você sabia" é algo que nós nunca tínhamos pensado. Então, é uma peça que foi discutida e que nós queremos segmentar, porque a gente sabe o seguinte: não adianta, eu não vou me 
comunicar da mesma forma com o grande investidor... a gente chama assim, o investidor profissional e o não profissional. Eu não falo de investidor pequeno ou grande, estou falando de investidor que conhece o mercado de capitais e de investidor que não conhece $o$ mercado. Eu consigo falar de "tag along" com o investidor profissional e não consigo falar de "tag along" com o investidor não profissional. Eu tenho que explicar detalhadamente o que é "tag along"... eu não posso falar de amortização de ágio com um investidor não profissional... então, é uma comunicação diferente. Aqui o que nós utilizamos, um dos mecanismos é este [o jornalzinho], o site nosso está em três línguas português, inglês e espanhol e tem oito mil e quinhentas páginas. Ele já foi construído pensando na segmentação, então, ao mesmo tempo que ele tem informações trimestrais, que é para o analista, para o investidor institucional - aquele profissional de mercado. Ele [o site] tem glossário, tem atendimento ao acionista, tem mecanismos muito mais úteis e didáticos para aquele usuário que não tem um profundo conhecimento. Nós temos um negócio chamado "consenso" no site, que é qual é a média do valor, que o mercado acha, do lucro líquido do Itaú no próximo trimestre. Para um investidor profissional, a gente só precisa colocar tabela para informá-lo, só que nós colocamos um texto antes explicando para aquela pessoa não profissional de mercado que está acessando aquela informação do Banco, exatamente porque está aquela informação ali: "isso aqui é uma média utilizada...". Explica para ele porque se não ele vai falar "não entendi nada" - pelo menos se ele ler, vai entender.

Então a pessoa que não tem o conhecimento da linguagem técnica, ela tem o mesmo acesso ao site?

Sim, tem glossário e outra, a segmentação da área é importantíssima na comunicação. Eu não posso me comunicar do mesmo jeito com públicos diferentes. A comunicação nossa, desde carta que vai para o acionista, carta para o mercado... é diferente. O jeito que eu me comunico com o analista é diferente do jeito que me comunico com o acionista. É um público diferente que tem que ser tratado de formas distintas. E não é só o site, é o "Ações Itaú em Foco" é o relatório anual, é a análise gerencial da operação etc,etc e etc. São vários meios que nós estamos colocando à disposição de todos os usuários, de modo diferente. $O$ jornalista não pode ser atendido da mesma forma, se você pega um jornalista da Gazeta Mercantil é uma coisa, se você pega um da Folha é outra. Vou te dar um exemplo: hoje existe uma questão que se discute muito que é a sustentabilidade das empresas, então se fala muito em meio ambiente, responsabilidade social, cultural, relacionamento com stakeholders, não é? Aí direto está acontecendo o seguinte, há um mês atrás eu estava dando uma palestra em Minas Gerais, no Primeiro Simpósio do Meio Ambiente Mineiro, 
perfeito? Falando sobre o Banco Itaú, pois é, pensa naquele público que cuida de meio ambiente, ONG, jornalistas, estudantes, etc e tal e eu falando de "tag along", de "conselheiro independente", de "governança corporativa" - a comunicação tem que ser diferente. Se eu começar a falar nos termos que eu falo numa USP, numa reunião, eles não vão entender nada. Então, quando um jornalista do meio ambiente conversa conosco, você tem que tomar muito cuidado na forma de comunicar porque você pode falar coisas que ele não vai entender absolutamente nada. Se for necessário falar, você vai ter que explicar muito bem para ele poder entender o que você está falando.

Processo de geração de informação

7. Como ocorre o processo: análise diagnóstico da situação, planejamento, ação, feedback, mensuração (e reinício)? Quais as informações e formas de captação de informação de cada fase? Existe algum problema ou curiosidade em alguma fase?

8 Como é feito o armazenamento das informações? (organização para acesso e recuperação) Existe uma coisa que nós acreditamos, que eu acredito muito nisso: a informação, antigamente era o "bem maior". Hoje eu acho que ela não é o "bem maior" - é a transmissão dela. A rapidez com que você se comunica, a forma de você se comunicar com as pessoas, com o mercado, entendeu? Quero dizer, se eu tiver uma informação e guardar ela, estou perdendo. E é uma grande bobagem, muita gente acredita nisso porque era o paradigma anterior, era o paradigma há cinqüenta anos atrás. Mas hoje não é, coma Internet, se você não conseguir a informação comigo, você vai conseguir com outros... é uma bobagem você guardar a informação. A grande questão é a seguinte, eu tenho que me comunicar bem e com a maior quantidade de gente possível, para transmitir a mensagem.

Bom, mas só voltando à questão...

Sim, como você forma, monta essa informação? Você já adiantou, tem esse lado que vocês vão até o público de interesse e discute com ele, o que querem saber e o que precisam saber...

A gente sempre tenta ser inédito aqui. Sempre tenta fazer coisa nova. E temos conseguido sempre fazer. Todo ano tem uma coisa nova que o Itaú está lançando, diferente na minha área. E é com base no quê? Pesquisa.

Agora para montar, para fazer as coisas usuais, vamos supor, esse material aqui são os ciclos Apimec que vamos fazer nesse primeiro semestre de 2005. Já fizemos Rio de Janeiro e já fizemos Brasília, quase cinco, agora vamos para Goiânia, Uberlândia, Uberaba, Salvador, Florianópolis e Recife. Essa apresentação, por exemplo, é totalmente concebida aqui, se 
você olhar esse nível que hoje é um nível bem elaborado, a Contabilidade é essencial - a Controladoria e a Contabilidade para você conseguir as informações é essencial. Ou é o grande foco onde a gente trabalhou. E aí vem toda a criatividade da área de montar uma forma de comunicar com o mercado de uma forma boa. Esse [impresso] é para analistas. Esse [outro impresso] foi o da apresentação de ontem - bem mais simples, bem mais direto, bem menor. Olha o tamanho desse aqui, tem 82 telas e o outro tem 12! A segmentação é importante, eu não vou apresentar isso [impresso maior] para eles porque eles não vão entender nada... Bom, quando nós começamos a área, a gente teve muita dificuldade realmente com informação... teve que trabalhar muito no público interno primeiro para melhorar e conseguir... Aqui no Itaú tem uma característica: a gente conseguiu primeiro conquistar o público externo para depois conquistar o interno...

Ruídos e Barreiras

12. Quais as principais barreiras internas ao trabalho de RI? As soluções são padronizadas?

13. Quais os entraves de comunicação interna mais comuns?

14. Quais as barreiras de recuperação da informação?

Sobre ruídos e barreiras, quais as principais barreiras internas ao trabalho de vocês? Vocês conseguiram soluções padronizadas?

Conseguimos. A nossa entrada no mercado interno foi através do mercado externo, quer dizer, devido ao trabalho e o reconhecimento que nós tivemos da comunidade de analistas e outros - somos uma área muito premiada no mercado. O que aconteceu foi que o mercado interno começou a nos ajudar muito, viu que era muito importante aquilo. O reconhecimento começou a vir de fora para dentro. Isso foi uma tática que a gente adotou desde o início. Em vez de ficar explicando o que é "relações com investidores" internamente, preferimos fazer o seguinte: "vamos atacar o público externo" - que aí o público interno vai saber o que é "relações com investidores" e vão ver o peso que tem isso. E foi um sucesso essa tática. $E$ hoje a gente tem uma grande facilidade de obter informações...

E o que era mais difícil era conseguir informações dos setores? Dos negócios ou era da Contabilidade mesmo?

A Contabilidade nunca foi um problema. Nem a Contabilidade nem a Controladoria, era muito mais na parte estratégica, alguns tipos de informações específicas por área. Não dados contábeis, dados contábeis você tem limitações de, às vezes, a informação não estar disponível, mas você discute e tal e o pessoal foi muito pró-ativo - Controladoria e Contabilidade juntas - no sentido de trazer a informação. Então, se não tinha a informação e 
a gente via a necessidade dela, daqui a seis meses aparecia, daqui um ano aparecia, enfim, existia um projeto para gerar aquela informação. Agora, quando você ia discutir alguns assuntos com alguma área específica, daí você podia ter problemas, resistências, ruídos "resistência é a melhor palavra: "não, não sei para quê essa informação" não é? Mas isso foi sendo vencido e hoje nós não temos problemas em relação a isso. Hoje nós temos facilidade. Nós e a Cemig somos as duas únicas empresas que estão no índice: Sustentability World Index - há cinco anos, que é o índice de sustentabilidade da Dow Jones. Esse índice é anualmente revisto, o Itaú já esta há cinco anos nesse índice e a minha equipe aqui sempre cuidou do Dow Jones, respondeu o questionário, que é o questionário mais difícil que nós respondemos anualmente e hoje mesmo eu estava discutindo com o diretor executivo e ele abriu informações que, se fosse há dois, três anos atrás, ele não abriria. Eles sabem da importância daqui, entendeu? A amplitude ficou muito maior, mas a alta administração - é essencial que ela esteja bem incorporada, acreditando na idéia e vendendo essa cultura internamente. Tanto o presidente do Banco, como o Diretor de Relações com Investidores e alguns executivos venderam muito bem a idéia porque o Banco sempre teve o seguinte objetivo: agregar valor para o acionista no longo prazo e essa "mantra" foi tão repetida aqui internamente que isso foi repassando para toda a estrutura, facilitando o nosso trabalho.

[Continuação da questão 8] E como vocês armazenam essas informações ?

O nosso site, para você ter uma idéia, ele tem demonstrações contábeis desde 1996. Ele tem a posição de dividendos mensais desde 1980, tem fatos relevantes desde 1997... O que eu cheguei à conclusão é o seguinte: o site é um grande canal, primeiro para exterminar problemas de comunicação da empresa com o público externo. Para você ter uma idéia, teve uma vez, no começo da área aqui de relações com investidores. Saiu no jornal, aliás em três jornais diferentes, no mesmo dia, três números diferentes para a quantidade de agências do Banco Itaú! Então, saiu no Estadão um número, na Gazeta Mercantil, outro e no Globo, outro número. Eu dei esse exemplo para falar o seguinte - olha pessoal, quem forneceu esse número foi a área de Relações com Investidores, quem forneceu esse outro foi a superintendência de planejamento, quem forneceu essa informação foi a assessoria de imprensa. Nenhuma das três estava errada, as três estavam certas: conceitos diferentes. Nós usávamos o consolidado, o outro usava só agências do Banco Itaú, e o outro usava, como estava no Rio de Janeiro, agências Itaú mais Banerj. E nós usávamos todo o conglomerado, que é o conceito correto. Se eu tenho agências que se chamam Banerj, Bemge, não importa: é o conglomerado Itaú. Um absurdo completo, numa questão boba, nem é uma questão elaboradíssima, sofisticada... era o número de agências. O que 
aconteceu com o site, a partir desse momento o site virou o grande site institucional da empresa. Foi uma coisa que, desde o inicio, eu batalhei muito. Então você homogeneíza dados da organização, pára de ter confusões sobre números, é aquele que está no site. Se aquele número estiver errado, pelo menos eu sei de uma coisa, está todo mundo recorrendo ao mesmo número, é um erro recorrente. Não é o erro de cada um dar um número. Então isso foi a primeira questão. E a segunda questão foi criar no site também o histórico da empresa. Então, nós acumulamos informações no site, nós não retiramos informações. Todas as apresentações da Apimec estão lá, desde 1998, quem quiser acessar, acessa, puxa a informação, baixa a informação sem problemas. A gente acredita que, com isso daí, nós estamos sendo transparentes com o mercado e amanhã, alguém quer pesquisar? Está fácil. E para nós também, ontem mesmo, eu estava procurando uma informação de 99, puxei do site e imprimi. Isso eliminou uma quantidade muito grande de pedidos de informação para nós. Você homogenizar, classificar... se está tudo no site - perguntas bobas pararam de chegar. "Onde está o fato relevante?" - Está no site, o número de funcionários? - Está no site...o analista não procurou mais a gente para perguntar isso, ele vai no site e pega.

Meios de divulgação

9. Quais os canais que a instituição se utiliza? Site, Serviços terceirizados, jornais, Bovespa CVM, (mais algum?)

Números...ah, Relatório Anual, Relatórios Trimestrais, tanto em português, quanto inglês, site de Relações com Investidores, inglês, português e espanhol, jornal - o informativo para acionistas, Ações Itaú em foco, email, Alert, wap Alert - que a gente manda mensagens por email e por Wap também, SMS - que é o short message, reuniões públicas para divulgar informações - estamos fazendo muitas reuniões públicas com o mercado, apresentações em congressos e em eventos em que nós somos convidados... E... tem algum outro canal? Carta para acionistas...

Vocês têm empresas terceirizadas?

Eu não acredito nisso. Na área de Relações com Investidores, nós não acreditamos nisso. Eu acho que o trabalho terceirizado no Brasil é muito ruim. Muito ruim, de Relações com Investidores. Eu só uso, ah, teleconferências também [resposta anterior]. Eu só uso, no caso, empresas terceirizadas para fazer a pesquisa pós-conferência - quero dizer, a gente faz a teleconferência e essa empresa vai lá e faz uma pesquisa junto aos analistas. Eu não posso ligar, porque ia ficar a coisa mais chata do mundo, "o que você achou da minha teleconferência?" Ele ia falar "ótima", todo mundo ia responder "ótima". Então, eu tenho que 
ter alguém isento, para perguntar e a pessoa ser honesta para a gente melhorar, ele vai falar das falhas que aconteceram. Eu não acredito em serviços terceirizados nesse caso, de serviços na área de Relações com Investidores - eu acho hoje que as empresas no Brasil são muito, muito fracas... Evidentemente: impressão, gráfica, é tudo terceirizado, não é? Evidente. Mas o conteúdo da informação é nosso, eu não passo isso, tem muita empresa brasileira que faz o conteúdo com empresa terceirizada, nós não fazemos. Por exemplo, para fazer um material desses [mostra o impresso], a empresa recebeu o power point de tudo isso aqui. A empresa recebeu as telas prontas, acabou, eu só discuti com eles a capa. Eles não elaboraram isso daqui para mim. Eles elaboraram o caderninho, esse formato aqui. É tudo feito internamente.

\section{Como ocorre a mediação?}

Temos essas ferramentas (impressos, site). Por exemplo, governança corporativa, tem aqui inglês e português, certo? Aqui tem até uma brincadeira [no impresso] "governança corporativa se faz com ações" - ações aqui está nos dois sentidos: ações no mercado de valores e ações de iniciativas. Então quando a gente chegava para discutir governança corporativa, o pessoal não entendia. Então a gente pensou "vamos fazer um folderzinho?" Para a gente se comunicar e falar só de governança corporativa? Foi um enorme sucesso. Então a pessoa bate o olho aqui e começa a ler... dá uma noção para ela, eu explico para ela. Quero dizer, eu estou em uma palestra e digo, "você está com o forderzinho aí?" Então pega ele, vamos falar o que é governança corporativa, conselheiro independente...Ou seja, em cima de um problema de que você não estava se comunicando bem, você gera uma peça de comunicação. É simples, boba, não custa nada isso daqui, entendeu?

As preferidas são esses pequenos relatórios essas folhinhas?

As folhas ajudam muito em coisas muito específicas, mas a gente produz muito relatório, por exemplo, o relatório anual é gigantesco não é? Você vê o Balanço social, olha o tamanho da "encrenca"... É uma peça muito importante, quero dizer, nós temos intervenções gigantescas em cima do relatório anual em relações com investidores. Esse ano a gente colocou a parte do GRI dentro do Balanço Social. Então há peças, depende do público, que você tem que ser mais elaborado, fazer uma peça mais explicativa... por exemplo, esse aqui é o relatório que a gente libera para os analistas, que é o PDF do Relatório Trimestral. Então, aqui, o analista vê cada operação - esse discurso aqui é um discurso extremamente técnico. Uma pessoa que não for do mercado de capitais, analista de bancos, que ler isso daqui não vai entender nunca. Minha intenção com isso daqui é atender o público 
especializado, então para esse público especializado, a gente libera trimestralmente, o equivalente a 121 páginas, em inglês, português e espanhol - as três línguas. Ao passo que para um acionista, vai o "ações Itaú em foco", o que ele quiser está no site, ele pode imprimir. Se ele quiser isso daqui, é só ele pedir. Alguns recebem, alguns vêm em reuniões do Banco, esse tipo de coisa, e tem lá, é só pegar. Quer dizer, depende muito do público, de como você vai agir com ele. Isso daqui, evidentemente, a gente distribui para quase todos os públicos alvos, é uma maneira fácil de ver como está indo a governança corporativa do Banco...

Vai pelo correio? Impresso?

Esse daqui especificamente não, esse aqui a gente distribui em eventos, congressos, reuniões ... direto. Porque esse daqui eu vou falar para ele na hora, eu vou ter uma tela que vai apresentar essa linha do tempo aqui, aí eu digo, "oh, vocês estão com esse folder aí, então vamos discutir esse folder?" Eu explico. Então ele tem a peça de comunicação na hora. O que vai pelo correio é essa peça aqui para os acionistas, tá ok? Então para cada público alvo, as peças são distintas. Para os jornalistas, por exemplo, a gente produz peças totalmente diferentes, até o comunicar é diferente. Porque o jornalista, ele tem outra cabeça, ele pensa diferente, etc. O comunicado que o Banco libera para o mercado de capitais como um todo, para o jornalista é diferente. Porque não adianta, aquela comunicação é para analista, para investidor institucional etc.

11. Qual a ordem de preferência do usuário, tem alguma preferida? Como é medida? Não, não, para cada público, você tem que segmentar e ponto.

O que o Sr. pensa da obrigação legal de publicação em jornais?

Eu pessoalmente sou contra. Não o "publicar em jornais" mas publicar no Diário Oficial, eu acho. É um custo muito grande, para o Itaú não é um custo fantástico, mas eu fico prensando em uma empresa de capital aberto, uma companhia pequena... é muito caro. Não é caro o Estadão, a Gazeta Mercantil... caro mesmo é o Diário Oficial. É monopólio, você tem que publicar lá, então eles cobram o que querem. Eu sou contra e vou te dar um exemplo: quando a gente publica o relatório anual, nós temos por volta de uns sete tipos de comunicação diferente em jornal. Em um jornal como o Gazeta Mercantil, a gente publica o balanço na íntegra, para o segmento de jornais tipo Folha de São Paulo e Estadão, para eles o processo é diferente. São duas páginas, com gráficos, pizzas, grandes chamadas, "olha, está no site toda informação, está na Bovespa e está na CVM, acesse lá e veja porque aqui 
estão os principais fatos" - porque a comunicação é diferente. Porque quem lê o Estadão e a Folha não vai querer pegar um balanço, com aquele tanto de nota explicativa, não é? Ele não está interessado nisso, a gente tem que chamar a atenção dele para ir até o site, ir falar com o corretor de preferência dele... mas, aquilo é para chamar a atenção dele para os resultados e as grandes questões. Aí a gente tem um outro nível de jornal, Jornal do Comércio, ICI, etc, é uma página e aí vai diminuindo, entendeu? Em uma página: grandes números, bem menos informações e chamando, remetendo para o site. Então é uma comunicação corporativa sobre o resultado anual da empresa e feita de forma distinta em vários meios de comunicação.

Então eu sou contra a publicação obrigatória das demonstrações contábeis completas no jornal. Isso não implica que a gente vai parar, porque, como eu te disse, a gente faz publicação em vários lugares, se eu pudesse diminuir o custo daquela primeira, com certeza a gente utilizaria aquele custo para publicar em outros jornais para outros lugares do Brasil ou para produzir outras peças promocionais. Ou seja, não implica que eu não queira ter aquele custo, não é isso. Implica sim que eu posso ter uma comunicação mais efetiva, melhor com meu público alvo, publico estratégico e não do jeito que está com a obrigatoriedade. Toda obrigatoriedade é ruim, quer dizer, se eu coloquei na CVM e na Bovespa, por que eu tenho que publicar em jornal? E eu acho que é muito pouca gente que lê. Eles poderiam muito bem solicitar à empresa que mandasse para eles impresso. Ia ser muito mais barato para empresa e para ele, que ia receber em casa etc. Quer dizer, você pode fazer outros mecanismos de ter acesso a essa informação, não necessariamente a obrigatoriedade.

Acréscimo de valor

15. Essa instituição mede o acréscimo de valor que o RI traz para ela na visão dos usuários? Há algum estudo?

Não dá para você medir isso, quer dizer, é uma conjunção de fatores. Várias ações nossas contribuíram muito para aumentar o valor, mas não é o posto, não é a área de RI sozinha... você precisa de outras áreas e vai discutindo até chegar a implantar uma iniciativa que aumente o valor da Companhia. É muito difícil dimensionar uma coisa dessas. Uma coisa mais simples que RI, que é a Governança corporativa, menos complexa talvez para mensurar, no máximo, no máximo ela deve, dependendo de estudos, aqui no Brasil se considera que uma ação aumentaria o valor de mercado em $21 \%$ com boas práticas de Governança Corpotariva. Mas é tão subjetivo isso... Como mensurar uma coisa dessas? É tão implicado em outras questões... Não, não temos uma medição desse tipo. Nem pensamos 
em ter. A mensuração é muito... vou te dar um exemplo: as premiações que a empresa recebeu devido ao trabalho da área de relações com investidores, aumentaram o valor da marca. Como mensurar isso? Não tem como mensurar. Hoje o Itaú tem a marca mais bem avaliada brasileira. Quem está falando isso é a "Inter?" - uma consultoria inglesa contratada três vezes pela revista "Isto é - Dinheiro". Ela avaliou as marcas brasileiras e nas três vezes falou que o Itaú era a empresa que mais valia no Brasil- a marca Itaú, a que mais agrega valor aos stakeholders. $A$ área de Relações com Investidores tem um peso nisso. $A$ quantidade de prêmios que já recebemos, a quantidade de reconhecimento... isso gera uma reputação de benchmarking etc. Como mensurar isso? Não tem como mensurar porque tem outras atividades e milhares de iniciativas da empresa juntas. Todas os comerciais que ela atua estão gerando também aquele valor da marca, não só a área de Relações com Investidores. Ela tem uma contribuição também, entendeu o que eu estou falando? Não tem como você destacar isso na minha visão...

16. A valorização financeira da empresa pode ser relacionada ao crescimento do programa do RI?

Com certeza, sem dúvidas. Como a gente aqui é meio chato, não é, fica atrapalhando todo mundo... falando... lembrando..."oh, pára de encher a paciência, Geraldo, você já falou isso dez vezes". Até alguém fazer o que você quer ou então responder: "pára de falar porque eu não vou fazer." São coisas muito interessantes... um exemplo é isso daqui: Regras Operacionais de Tesouraria [um manual impresso]. O que são essas regras? São regras, isso aqui é uma coisa pública - foi mandado para CVM. Mensalmente nós estamos divulgando quanto que a tesouraria do Banco está comprando, negociando com ações do Banco, ok? Eu não sou obrigado a fazer isso, isso tudo é voluntário. Pois é, isso daqui como surgiu? Só para você entender mais ou menos o mecanismo - essa é uma contribuição da área. 0 nosso comitê de divulgação estava discutindo a questão de compras para a tesouraria... eu pesquisei e descobri que não tinha regras, no mundo inteiro, as empresas não tinham regras de como elas negociavam ações de emissão delas próprias. Existem órgãos reguladores, como a CVM, que tinham regras de como as empresas poderiam ou não poderiam comprar, os limites, horários etc. Cada país tem um critério. Eu fiz uma pesquisa gigantesca e inclusive escrevi um artigo na revista "Capital Aberto" sobre esse assunto - o que eu descobri em nível mundial. Aí nós pesquisamos e descobrimos que na França era de um jeito, na Alemanha era outro, nos Estados Unidos era outro... cada um tinha um jeito, mas tinha alguns que eram parecidos em algumas questões, enfim, eu fiz um arcabouço disso e levei para a reunião do comitê e falei "olha: as práticas mundiais, não existe nenhuma 
empresa brasileira com regras operacionais, não existe nenhuma empresa no mundo com regras operacionais...". Só se tiver uma empresa muito pequena que eu não consegui achar, as maiores empresas do mundo, os maiores conglomerados do mundo não têm regras operacionais, eu garanto, eu pesquisei, não têm. Bom e aí nós fizemos a nossa, as nossas regras operacionais. Então aqui nós estabelecemos como que a tesouraria do Banco pode operar, como exatamente: "olha, ela pode operar $25 \%$ do volume das médias dos últimos 20 pregões, você tem limite de horário aqui, ela não pode operar nos 20 primeiros minutos, nem nos dez últimos minutos, ela não pode formar preço, ela não pode pagar preço maior que o mercado está pagando na hora... tem um monte de regras aqui. É o seguinte, a minha tesouraria tem regras! Ela não pode entrar no mercado operando...Mas qual é a importância disso? É muito importante para o acionista porque ele não sabe como a tesouraria do Banco está formando preço, se ela está formando ou não está, se ela está intervindo ou não está, se ela está arbitrando o mercado ou não está... com base nisso ele vai saber, o investidor acionista, qual é a postura, como a tesouraria do Banco entra e compra. Mensalmente eu vou divulgar isso. Então eu estou só te dando o exemplo do que é uma pesquisa, discutida e se chegou nessa peça. Essa peça foi aprovada pelo Conselho de Administração do Banco Itaú. Foi apresentada numa reunião da Apimec, cinco minutos antes, a gente mandou para a CVM e a Bovespa, porque a CVM tem que ser a primeira a saber, e apresentamos ao mercado. Eu quero ter Governança Corporativa, eu quero ter regras operacionais e para isso eu criei voluntariamente regras que estabeleçam que quando nós que estamos aqui não estivermos mais aqui, a empresa tem regras e tem estrutura para manter a Governança Corporativa da empresa. Não é só hoje a cabeça de um, amanhã, a cabeça de outro e você não sabe o que vai acontecer. $A$ área de Relações com Investidores tem um peso gigantesco nisso, estou te dando um exemplo, como outras coisas do passado que a gente fez e chegou no nível que nós estamos hoje. Se eu mensuro, se eu consigo mensurar qual é o efeito disso no mercado, eu não consigo. Eu consigo saber o seguinte: cada vez mais iniciativas e ações possibilitam uma estrutura de longo prazo da estabilidade da empresa. A questão ambiental, até a gente criar o Comitê de Responsabilidade Ambiental, eu era o cara mais chato do Banco. Bom, chegamos e criamos o Comitê, hoje temos o Comitê de Responsabilidade Ambiental, discutindo a postura do Banco em relação a esse assunto. A gente está criando mecanismos, há o fundo de responsabilidade ambiental que só a ABNR -Itaú que tem fundos nesse tipo de foco. Aderimos aos princípios do Equador, que para financiamentos acima de U\$150 milhões, nós temos que ter o relatório de impacto ambiental, tem que ter um especialista em meio ambiente junto ao processo de consultoria ....Então, vários mecanismos nós estamos adotando e posturas que só foram 
construídas a partir do momento que geramos uma discussão dentro da área e essa discussão ampliou-se e começou a tomar uma nova postura dentro da organização. 


\section{Petrobras}

Identificação

1. Nome, cargo, formação, breve histórico.

2. Equipe: tamanho, principais funções. Essas funções são compartilhadas? Ou há divisão de trabalhos, etapas, clientes etc?

Entrevistado:

Marcos Vinícius Guimarães

Coordenador de Articulação Institucional

Engenheiro de Produção - UFRJ com Pós-Graduação em Finanças - IBMEC

Após trabalhar na AIG Seguros (2 anos) e na Esso Brasileira de Petróleo (5 anos), passei a integrar a força de trabalho da Petrobras em 2001, onde já ocupei posição na área de Estratégia Corporativa ( 2 anos) antes de me transferir para a área de RI.

A equipe atualmente é formada por 24 empregados, sendo 1 Gerente Executivo, 4 Gerentes, 5 Coordenadores, 1 Consultor, 2 profissionais de nível superior e 11 profissionais de nível médio.

3. Quem são os usuários das informações? (investidores institucionais e pessoas-físicas? Há outra classificação?)

Investidores institucionais, individuais, cotistas de fundos FMP-FGTS Petrobras, investidores de renda fixa, imprensa, consultorias, publicações especializadas, demais stakeholders

4. Como a instituição os identifica? Faz pesquisa própria? Utiliza dados de outras fontes? Quais?

Através de contatos próprios e consultoria especializada.

5. Como são classificados (tipos de investidor)?

Sell-side, Buy-side, Renda Fixa, Clubes de Investimentos, Corretoras, Investidores Individuais. 
6. Tipos de informações: há produtos customizados? Mesmo com a democracia da divulgação, há explicações ou formas diferenciadas de mediação? A linguagem técnica é de conhecimento obrigatório?

Todos os produtos são disponibilizados para todos os públicos, embora existam produtos elaborados especificamente (customizados) para atender a públicos específicos, sendo sua forma, veículo e linguagem, adaptados conforme a necessidade.

Ex: Chat e informativo aos acionistas -> voltados para investidores individuais

Webcasts sobre Resultados e Roadshows -> voltados para investidores institucionais

Processo de geração de informação

7. Como ocorre o processo: análise diagnóstico da situação, planejamento, ação, feedback, mensuração (e reinício)? Quais as informações e formas de captação de informação de cada fase? Existe algum problema ou curiosidade em alguma fase?

As informações disponibilizadas no website ou outros veículos são obtidas de fontes públicas ou das áreas de negócios da Companhia. As informações que constam do Relatório Anual (20-F) são certificadas por cada área, através de uma pirâmide de assinaturas (gerentes executivos, diretores etc.) até a certificação final pelo presidente.

8 Como é feito o armazenamento das informações?

Estão disponíveis no website informações contábeis desde 1998. Os arquivos não são substituídos, uma vez que é cópia fiel das informações apresentadas à CVM / SEC.

As demais informações (operacionais, governança, apresentações, informações aos acionistas etc.) têm atualização permanente.

Meios de divulgação

9. Quais os canais que a instituição se utiliza? Site, Serviços terceirizados, jornais, Bovespa CVM, (mais algum?)

Website de Relacionamento com Investidores;

Fatos relevantes e comunicados ao mercado; 
Apresentações para a imprensa;

Webcasts e roadshows com analistas e investidores;

Chat com investidores individuais;

Hotline e sala privada para atendimento aos acionistas;

Informativo trimestral Petrobras em Ações (acionistas e cotistas de fundos FMP-FGTS);

Relatório anual (Atividades, Relatórios Financeiros e Balanço Social) e Form 20-F;

Participação em eventos do mercado de capitais.

A Petrobras teve reconhecimento através de diversos prêmios, incluindo em 2005 o Prêmio Transparência da ANEFAC (ganho pela segunda vez consecutiva).

10. Como ocorre a mediação?

A mediação é feita através dos canais acima mencionados. Além disso, mantemos contato direto com os analistas que cobrem a Petrobras e com a Imprensa.

11. Qual a ordem de preferência do usuário? Como é medida? O que o Sr. pensa da obrigação legal de publicação em jornais?

O caminho natural é a pesquisa no website e nos relatórios oficiais da Cia (relatório anual, 20-F etc.) e depois um contato mais direto com a área de RI.

As publicações em jornais são importantes para alcançar o maior número possível de partes interessadas quando estamos divulgando fatos relevantes, como um aviso aos acionistas, por exemplo.

Ruídos e Barreiras

12. Quais as principais barreiras internas ao trabalho de RI? As soluções são padronizadas?

Tendo como objetivo-fim a transparência e tempestividade na divulgação de informações, as principais barreiras ao trabalho de RI estão na agilidade de obtenção de informações junto às áreas de negócios e corporativas.

13. Quais os entraves de comunicação interna mais comuns?

Normalmente não encontramos entraves na comunicação interna. 
14. Quais as barreiras de recuperação da informação?

Como já dito, o maior entrave é na agilidade de resposta das áreas de negócios e corporativas.

Acréscimo de valor

15. Essa instituição mede o acréscimo de valor que o RI traz para ela na visão dos usuários? Há algum estudo?

São realizados estudos de percepção interna e externa.

16. A valorização financeira da empresa pode ser relacionada ao crescimento do programa do RI?

Não. A valorização financeira da empresa é função de inúmeros fatores tanto endógenos como exógenos, sendo que estes últimos estão totalmente fora do controle da Cia.

\section{Ultrapar S.A.}

Identificação

1. Nome, cargo, formação, breve histórico.

Entrevistadas: Maria Fernanda Leme Brasil e Maristela Seiler - Gerente e Analista de Relações com Investidores da Ultrapar.

2. equipe: tamanho, principais funções. Essas funções são compartilhadas? Ou há divisão de trabalhos, etapas, clientes etc?

A equipe é composta por um Diretor Financeiro e de Relações com Investidores, um Superintendente de Planejamento e de Relações com Investidores, uma Gerente de Relações com Investidores e duas Analistas. As formações principais são Engenharia e Administração de Empresas.

Um conhece a função do outro e é um trabalho... a área de relação com investidores, se não tiver uma comunicação muito forte entre as pessoas, principalmente dentro da equipe, internamente, a área não funciona direito. É uma área com muita troca de informação para todos os lados: para cima, para baixo, para os lados... a gente tem sempre que estar conversando, sempre estar alinhado naquilo que é a filosofia da companhia, modo de 
trabalhar, onde quer chegar, então é tudo muito... muito alinhado, mesmo, eu diria a palavra certa, muito conversado, muito costurado...

E essa equipe de vocês tem uma formação multi-disciplinar? Ou tem um peso maior de um curso?

Olha, eu diria que maioria... dois cursos fundamentais: engenharia e administração, mas a forma como está desenhada hoje, fora o nosso diretor, que é engenheiro, mas tem mestrado em administração, o resto é tudo administrador...

3. Quem são os usuários das informações?

Olha, é mercado de capitais de uma forma geral, aí entra banco, seja a parte de analista "sell side", que escreve relatórios, ou "buy side", que é o pessoal que faz análise de carteira, monta carteira, portifólio, responsáveis por fundo de investimento de banco, de pequenos "assets", o pessoal de previdência privada, que administra recurso de previdência privada... investidor individual e órgãos regulamentadores, então, o BOVESPA, CVM, a SEC dos Estados Unidos, a própria New York Stock Exchange, a gente conversa bastante... Então é um público, é um público mais específico de mercado de capitais, salvo uma pouco o investidor pessoa física, que daí ele, como você falou, ele não tem um conhecimento técnico tão apurado que o resto tem...mas ele tem um conhecimento razoável de mercado, de economia, de uma forma geral. Tem algumas peças que a gente acaba fazendo, como por exemplo, relatório anual da companhia: é de nossa responsabilidade. E daí é o público que entra, contato comercial, é para todo mundo, eu distribuo para companhia inteira...é a peça publicitária institucional mais forte aqui dentro.

A maior parte do público usuário são investidores institucionais?

É... Investidor institucional ou pessoas com nível técnico muito bom, que faz a análise de crédito, por exemplo, analista "sell side", de fato um pessoal com conhecimento de mercado de capitais.

4. Como a instituição os identifica? Faz pesquisa própria? Utiliza dados de outras fontes? Quais?

5. Como são classificados (tipos de investidor)?

Se a consulta, por telefone, por exemplo, a gente sempre pergunta quem tá falando, onde trabalha, de que área que é. A gente procura sempre saber quem que é a ponta final, até para melhor forma de comunicar com a pessoa. Quando é através de site, a gente tem um 
cadastrinho para pessoa se identificar... dessa forma.. e, através dos anos, que o contato vai se estreitando com essas pessoas...

Então, o próprio sistema tem aquela memória das perguntas que foram feitas?

A gente tem um sistema de CRM na área, é um sistema que a gente comprou de uma empresa americana que é específico para área de relação com os investidores, onde a gente coloca o perfil da pessoa, o histórico do relacionamento, então, a cada contato a gente cadastra lá: "ligou tal dia... pediu tal informação"... então, aí, por pessoa, a gente vai sabendo por exemplo o que é que olha mais, qual é mais o foco de preocupação, sabe, o foco de interesse, etc.

Mas vocês não utilizam também o serviço de terceiros? Contratam alguma empresa? A gente utiliza, mas não de uma forma constante. A gente para eventos específicos que a gente faz, por exemplo, o "conference call", eu tenho uma empresa que me ajuda com tecnologia. Toda a parte estrutural, eles me ajudam. Mas a gente que monta as apresentações, a gente que define essa discussão de como prosseguir, o que discutir, o que é que a gente vai abordar, etc, é feito internamente. É mais estrutura de apoio. Assim como eventos com os analistas, a gente contrata uma empresa especializada, para fazer esses eventos... tira um pouco o foco da minha preocupação em estrutura, deixa o foco em comunicação, em trabalhar o material de divulgação... aí, eles cuidam, aí eles armam o circo...

6. Tipos de informações: há produtos customizados? Mesmo com a democracia da divulgação, há explicações ou formas diferenciadas de mediação? A linguagem técnica é de conhecimento obrigatório?

Não, a gente ainda não faz isso. A gente atende todo mundo... a comunicação é de fato uma comunicação em massa, única. Não há diferenciação. Tem algumas empresas, por exemplo, a Petrobras, que tem separado a área de relações com o investidor para pessoa física, porque o volume é muito grande, é muita gente, daí faz sentido, daí o careta fala com jeitinho, mas o material disponível deles também é o mesmo, para todo mundo, mas tem uma área... uma comunicação mais direcionada. A gente aqui, até em função da nossa base de acionistas ser bem menor que a da Petrobras, não tem necessidade, então normalmente acionista pessoa física liga, a gente atende pessoalmente, conversa, dá a mesma atenção que daria a qualquer outro investidor de mais porte. 
E sem diferenciação... o que vai acontecer é que essas perguntas desse cara são perguntas mais light, menos técnicas...

Acontece de, às vezes, o usuário ligar com uma pergunta tão elementar que você precisa explicar o conceito primeiro, ver se é isso mesmo o que ele quer saber?

Acontece... e aconteceu, como eu te falei, de um acionista pessoa física que ligou para perguntar um negócio do balanço que a gente não sabia... então, eu peço para checar... "deixa eu falar com o pessoal da minha contabilidade e eu te volto". Aí checamos, voltamos, discutimos, esse aí ele fazia a análise do balanço mesmo. Como pessoa física, ele ia lá e analisava todas as variações.

A questão de material não existe, lógico, a diferenciação: a gente manda esse para um e para outro, mas tem desde demonstrações contábeis que a gente divulga nos jornais, que é totalmente técnico, até o relatório anual, que é linguagem mais acessível, os próprios relatórios trimestrais, também são muito mais explicativos... com os destaques, sem entrar em muitos detalhes. Porque a informação contábil per si ela não explica nada: é um número, e a função nossa é explicar aquilo, e a gente procura fazer isso de uma forma bem didática, para que qualquer um que pegue aquilo, mesmo que não entenda a tecnicidade de dados contábeis, entenda o que está acontecendo com a empresa, que ambiente que ela viveu, como que foi o mercado, sabe? A gente procura fazer isso de uma forma... de uma linguagem simples, transparente, objetiva, que atenda todos os públicos. O site nosso também é um site bem explicadinho, tem bastante informação, bem didático, sabe? Não parte do pressuposto que todo mundo sabe tudo, muito pelo contrário, fica explicando as coisinhas, o que é, o que não é, então tem uma função didática na apresentação do site.

Processo de geração de informação

7. Como ocorre o processo: análise diagnóstico da situação, planejamento, ação, feedback, mensuração (e reinício)? Quais as informações e formas de captação de informação de cada fase? Existe algum problema ou curiosidade em alguma fase?

8. Como é feito o armazenamento das informações? (organização para acesso e recuperação)

A gente procura perceber um pouco qual que é a percepção do mercado em relação à empresa. O trabalho mais rico nosso, é estar sempre de olho em como o nosso público nos enxerga, o que viu, o que ele gostaria de ver, o que está bom, o que está ruim na 
percepção dele, a gente procura trabalhar isso em função daquilo que a gente entende que é a companhia: ele está entendendo direito a nossa mensagem ou não? Então a gente sabe que está faltando comunicação nessa parte, vamos atacar um pouco, é assim que funciona. E alguns investidores, a gente tem uma qualidade boa de investidor, graças a Deus, que são investidores que estão preocupados, de fato, em agregar valor à companhia, não é investidor que liga e reclama: "pô, o lucro não foi bom ou foi bom"... ou: "vocês distribuem poucos dividendos" ..., São pessoas com um nível de conhecimento e conhecimento principalmente de agregação de valor, de geração de valor, são pessoas que ligam, que vêem oportunidade, sabe? Que vêem questões e que vêm discutir com a gente. Por exemplo, a empresa hoje dá "tag along" para os acionaistas, no caso de venda de controle, quem está comprando o controle tem que fazer a mesma oferta de valor para todos os acionistas, ou seja, você elimina o prêmio pelo controle, e esse instrumento é um instrumento que, quando a gente abriu o capital, as pessoas demandaram: podia pelo menos ter "tag along", porque o grupo controlador é um grupo só grande... Ah, então tá, e ponderamos, e vimos que fazia sentido, ah, então qual o melhor instrumento para fazer, chamamos advogados, sentamos, construímos isso juntos, e demos o "tag along".

Então é um processo de troca muito bom, e isso foi gerando ao longo do tempo uma confiança muito grande dos investidores, na companhia, na administração da companhia... faz uma bela diferença.

Os investidores de vocês têm bem o perfil de sócios?

De fato têm. Aquela coisa: ah... é acionista minoritário... não existe aqui... o cara é acionista! E ele se sente como acionista, como sócio... Isso é legal.

E como é feito o armazenamento?

A gente deixa tudo no site...Então, a companhia abriu o capital em 99, a gente tem informações de 99... de 98 em diante, no site, em planilhas... disponíveis, tem as demonstrações, tem relatórios anuais, tem relatórios da SEC. A gente deixa tudo disponível no site.

Fica tudo arquivado lá, vocês não chegam a retirar não...?

Por enquanto está tudo lá. A gente não tem nenhum problema, e... nunca tivemos nenhuma questão.

Meios de divulgação 
9. Quais os canais que a instituição se utiliza? Site, Serviços terceirizados, jornais, Bovespa CVM, (mais algum?)

10. Como ocorre a mediação?

11. Qual a ordem de preferência do usuário? Como é medida? O que o Sr. pensa da obrigação legal de publicação em jornais?

Olha, os mais utilizados são: o site, é lógico que BOVESPA, CVM e SEC porque são obrigatórios, os jornais obrigatórios, às vezes acabamos publicando algum aviso aos acionistas, algo que não seria obrigatório, mas que é legal, que é importante. Os serviços terceirizados, a gente tem essa empresa que a gente contrata, eles tem um "mailing list", bem amplo, bem abrangente, então eles fazem a distribuição através do "mailing" deles também para bastante gente.

E vocês têm também um "mailing" da ULTRAPAR?

Temos.

Quais jornais em que vocês publicam?

A gente, legalmente, é Valor e Diário Oficial do Estado, do Estado de São Paulo. Esse que eu acho uma bobeira, sabe, o Valor, ainda vá lá, porque tem bastante gente que lê, do nosso mercado de capitais, mas Diário Oficial, é caro, e ninguém lê. E agora, por exemplo, quando é ano, é balanço anual a gente publica um resumido no Estado, e na Folha e na Gazeta também. A gente amplia um pouco pela relevância, que é ano, e aí a gente faz resumido para não ficar tão caro. Ou quando tem alguma aquisição grande, daí a gente chega a publicar até em revista, como coisas institucionais.

E vocês avisam a edição do jornal, isso já está no site, por exemplo, eu sou investidora, mas eu não assino o Valor, e quero saber quando que vocês vão publicar, quando vai sair o balanço...?

A gente tem no nosso site um calendário de eventos.

E quais os produtos? Como ocorre a mediação? Além do jornal, vocês divulgam... boletins... eu tinha anotado aqui um relatório trimestral, né?

Esse relatório trimestral não é publicado. É um relatório da companhia sobre o desempenho. Ele base para as informações. Mas aí ele é disponibilizado no site. No nosso site, no site da CVM, no site da BOVESPA, é distribuído via mailing. 
E junto com a parte técnica, de gráficos, de números, vocês montam a parte explicativa, o "press release" e isso é um padrão?

É um padrão.

Qual é a ordem de preferência do usuário, apesar da maioria ser institucional, existe um caminho comum? Primeiro o site, depois eles telefonam...?

Olha, tem de tudo... tem gente que faz o dever de casa super bem, e liga bem para perguntar a vírgula da vírgula, e gente que não leu nada, que viu só o lucro foi tanto, vi aqui que caiu... e diz: "deixa eu ligar lá para bater um papo"....Aí a gente acaba tendo que explicar mais detalhadamente, aí demora mais... esse é o caso que está com um pouco de preguiça...a gente já sabe direitinho.

Tem assim uma maioria, o mais comum?

Não, tem todo jeito. Não tem preferencial.

De um modo geral o pessoal dá uma olhada, e de uma forma geral a maioria hoje das pessoas é tudo via site, vêem tudo, já sabem onde tem todas as informações no site, vão, olham... Aí, para tirar duvidada, a maioria liga, a maioria liga, daí quer falar por telefone, quer bater um papinho...

O que eu percebo é que, minha impressão, o pessoal tem uma certa resistência a fazer a perguntinha já no site, porque aí tem que explicar, tem preguiça de digitar, a impressão que eu tenho é que eles lêem, analisam... e ficou com dúvida? Liga. É mais rápido...

É. É isso mesmo. E daí a gente vai vendo também. É bom quando liga a gente vai pegando uma percepção: ah, "o quê que você achou do resultado?"...e a pessoa fala: "ai, eu fiquei preocupado com isso"... "isso aqui me surpreendeu positivamente"... aí a gente vai capturando...e a gente de uma forma ou de outra acaba endereçando isso nas próximas comunicações. Por exemplo, "o pessoal ficou preocupado com o volume de vendas daquela região", aí no próximo a gente explora um pouco mais, sabe...

Aqui eu tinha perguntado o que você acha de publicação de jornal, mas você já respondeu, né?

Eu, Diário Oficial eu acho um problema. É ruim quando é obrigatório, porque às vezes é até do nosso interesse, por exemplo, o Estado e Folha, a gente publica porque a gente quer que atinja o investidor pessoa física, formador de opinião, sabe, algum tipo de profissional que 
nos interessa, trabalhar um pouco a imagem do grupo, né? Mas, o Diário Oficial? Nunca vi um leitor...

Ruídos e Barreiras

12. Quais as principais barreiras internas ao trabalho de RI? As soluções são padronizadas?

13. Quais os entraves de comunicação interna mais comuns?

14. Quais as barreiras de recuperação da informação?

Eu te diria que assim, aqui a área de RI é uma área muito respeitada. É uma empresa que tem uma cultura de respeito ao acionista minoritário muito grande, então não é só: "ah, é o cara que está em bolsa", "é o cara que tem preferência"...não é assim que funciona, entendeu? A gente deve satisfação para os nossos acionistas...é uma postura que vem de cima isso. Esse "enforcement" todo é um "enforcement," é um evento que se passa de cima para baixo, então a gente tem muito pouca dificuldade de conseguir informação, muita pouca, e isso é muito bom, a gente tem aqui uma facilidade de navegar pelos diversos departamentos da empresa, sentar, conseguir conversar, muito bom.

O que tem às vezes, assim...a pessoa gostaria de falar de um jeito, e outra de outro jeito, ou uma unidade não vai bem, ou está com algum problema pontual, e o cara acha que não tem que pôr do jeito que a gente colocou, tem que pôr de outro jeito, sabe? Compilar a informação acho que é mais difícil que conseguir a informação, chegar num consenso de comunicação às vezes é muito mais difícil que de fato entender o que está acontecendo... 0 consenso às vezes é tumultuado.

Quanto tempo mais ou menos tem o RI aqui da empresa?

Tem 6 anos. $A$ bem da verdade tem 5 anos, porque abriu o capital em 99, e a área foi montada em 2000, porque já tinha uma gerente que estava em licença-maternidade. Ela voltou, estruturou a área, funcionou, abriu em 99, funcionou capenga 3 meses, aí a estruturação de fato vem 4 meses depois de estruturada...

Existe alguma dificuldade para acessar uma informação? Acontece de algum usuário ligar e dizer que não conseguiu no site alguma informação?

Menos o que não conseguiu pegar no site...às vezes eles falam: "eu não tô conseguindo abrir o arquivo"..."você pode me mandar o arquivo por email?", ou no caso desse acionista que perguntou uma coisa do balanço, da nota explicativa do balanço que a gente não sabia responder... aí, a gente falou: não sei agora, ... 
E para vocês é simples ter o acesso?

Sim, a tecnologia ajuda bastante.

Acréscimo de valor

15. Essa instituição mede o acréscimo de valor que o RI traz para ela na visão dos usuários? Há algum estudo?

16. A valorização financeira da empresa pode ser relacionada ao crescimento do programa do RI?

Ah, como a área de RI surgiu junto com a ação em bolsa cotada, não é que já tinha a ação e daí, montou um trabalho, tinha um antes e depois, mas o que a gente percebe hoje em diante é um pouco de mudança de..., são valores adicionados à empresa que antes não tinha. Então essa questão da transparência, da ética no trabalho, da ética com os acionistas, da boa governança, preocupação com a boa governança, não tinha antes. E hoje tem, isso é um valor numa empresa, e a própria confiança no "management", como não era aberto, não tinha toda essa transparência, essa visibilidade, não tinha tanto o que as pessoas falarem: "ah, o 'management' é muito bom", porque se conhecia muito pouco, uma empresa de capital fechado, um mercado bem específico, não é um mercado que está muito próximo ao público, o mais próximo que está é o entregador de gás, é bem diferente. Hoje em dia tem uma imagem de qualidade associada à empresa em função de ter capital aberto, e das próprias ações que a gente vem fazendo, o posicionamento junto ao mercado. E quando os relatórios saem, de avaliação da empresa, sempre vem "boa governança"... e vem como um valor da ação, da empresa.

Então, na opinião de vocês existe uma valorização associada a esse serviço de comunicação? Existe sim e à conduta de governança. É difícil mensurar, quanto do valor da minha ação que tem isso dentro.

\section{Unibanco S.A.}

Identificação

1. Nome, cargo, formação, breve histórico 
Entrevistados: Leandro Alves da Silva e Nira Bessler - gerente e analista do setor de relações com Investidores do Unibanco.

2. equipe: tamanho, principais funções. Essas funções são compartilhadas? Ou há divisão de trabalhos, etapas, clientes etc?

A equipe é composta por um Diretor, um superintendente, um gerente e cinco analistas de mercado. As formações são economista e jornalista (os entrevistados), há também pessoas formadas nas áreas de engenharia, administração e contábeis.

A gente tem uma formação multidisciplinar, mesmo porque o trabalho, ele é bastante multidisciplinar, embora a gente tenha que ter uma formação mínima básica em Contabilidade, finanças, conhecer mercado de capitais, estratégia da empresa e estratégia dos concorrentes.

A gente compartilha bastante, não só o conhecimento, mas também algumas funções. É necessário estar sabendo, como a equipe é muito pequena, quando uma pessoa sai de férias a outra tem que assumir os trabalhos, então tem uma certa especialização - o que é inevitável numa área com bastantes tarefas, mas de uma maneira geral, a gente procura que pelo menos duas pessoas saibam fazer uma mesma tarefa e às vezes até mais que duas. Para que se possa ter back up e as pessoas saírem de férias e até uma certa rotatividade nas atividades - e não ficar uma pessoa só fazendo sempre a mesma coisa.

3. Quem são os usuários das informações?

4. Como a instituição os identifica? Faz pesquisa própria? Utiliza dados de outras fontes? Quais?

5. Como são classificados (tipos de investidor)?

6. Tipos de informações: há produtos customizados? Mesmo com a democracia da divulgação, há explicações ou formas diferenciadas de mediação? A linguagem técnica é de conhecimento obrigatório?

O usuário de um site de RI é um público bastante diversificado. O publico básico, pelo menos o público-alvo hoje central do site de RI são os investidores. Os investidores que tem ações do banco, ou os investidores em ações que se interessam pelas ações do Unibanco, aí você tem desde a pessoa-física que tem ações do banco e acompanha até principalmente os analistas de investimento, que é a pessoa que orienta o investidor sobre o que fazer com o dinheiro, quais papéis comprar, quais vender... este é um cara bastante crítico e busca sempre uma quantidade, uma diversidade e uma profundidade de informação bastante razoável. Você tem também outras empresas. O site de relações com investidores além de atender o próprio público que são os investidores e os analistas de investimento, ele acaba 
também tendo outra função - a de explicar a própria empresa, quando uma pessoa está procurando fazer negócios com o Unibanco, ou quando alguém está procurando emprego e quer conhecer melhor a empresa ou para o governo quando ele procura informações sobre o banco ou algum órgão de fiscalização... então é sempre diversificado, tem um público-alvo principal, mas tem também um outro público que acessa com freqüência - jornalistas, estudantes, outras empresas. A gente acaba até recebendo emails e, pelas pessoas que se comunicam com a gente, a audiência costuma ser bastante diversificada também.

Vocês dividem basicamente em institucional e individual?

A gente não costuma ter uma divisão tão clássica assim até porque muitas vezes a informação que serve para o institucional, é a mesma que serve para o individual; a gente costuma ter camadas de informação - a gente tem um nível de informação que atente uma pessoa com pouco conhecimento técnico, às vezes pouco tempo a se dedicar ao banco, ele vai ter informações básicas em lugares de fácil acesso e aí você cria camadas mais profundas até chegar nas demonstrações financeiras - o que é uma publicação que já demanda um pouco de conhecimento técnico para um perfeito entendimento, outras informações societárias da empresa que a pessoa precisa ter um pouco de familiaridade, mas até aí se uma pessoa, por exemplo um investidor estrangeiro, ou a pessoa que $o$ Unibanco é só um pedacinho do investimento dele e não tem muito tempo para locar para aquilo, ele tem as informações macro já assim facilmente disponível no site. À medida que ele vai tendo mais tempo ou mais capacitação ou mais interesse em conhecer melhor o banco, ele vai encontrando outros níveis de informação que permite que ele se aprofunde.

E como o Unibanco identifica esses usuários, como vocês formam esse perfil das camadas para fornecer essas informações diferenciadas?

Olha, basicamente a gente busca ver quais as páginas do site são mais acessadas, onde precisa haver margem de informação mais proeminente, a gente também procura ver pelas conversas com os investidores, reuniões que a gente faz com eles, muitas vezes a gente recebe emails ou telefonemas procurando alguma informação, então a gente já sabe quais são as informações mais demandadas e a gente procura deixar as informações mais demandadas à disposição. À medida que você atente esse primeiro nível de informação, você começa a colocar mais coisa no site. Tem informações que são periódicas, é preciso atualizá-las a cada três meses ou menos e tem informações que são mais perenes, você atualiza à medida que tem uma mudança mais significativa no Banco. Para ter uma noção, a gente procura pensar assim: o que uma pessoa com meia hora de tempo precisa saber 
sobre o Banco? O que uma pessoa com mais tempo... e assim sucessivamente até aquela pessoa que lê o site do Banco com freqüência, coleta todas as informações recentes colocadas no site, procura extrair delas o que ela precisa pro dia a dia. Mas vai muito de sensibilidade também, da gente conversar com as pessoas e ver quais são as informações mais demandadas, um pouco de quantitativo - ao ver a página do site mais acessada, os arquivos que têm mais download, os arquivos que têm mais demanda e também de ver a própria dinâmica do mercado. Num mercado de capitais, dentro de relações com investidores, quais são as informações que as pessoas demandam mais? É também um pouco temático: teve uma época, há uns dois ou três anos atrás que o peso era forte na parte de responsabilidade social, o que os bancos e as empresas estavam fazendo por aí. Hoje, não que isso tenha perdido o foco, mas a gente também é bastante demandado para informações de governança corporativa... então os acionistas e as pessoas querem saber como é o processo de tomada de decisões dentro da empresa, como é garantido o direito e o respeito aos minoritários etc. As épocas, elas também modulam o tipo de informações que tem lá. O mais importante é que a gente quando coloca um conteúdo novo no site ou procura dar uma nova informação, a gente sempre acrescenta, a gente nunca tira. Então não é porque hoje estamos sendo demandados por um outro tipo de informação que a gente tira o que estava no site: a informação continua, só que tem outras coisas também disponíveis para as pessoas.

Então, basicamente, esse trabalho é interno. Vocês levantam as necessidades de acordo com essa verificação de busca aqui mesmo?

Periodicamente a gente também faz pesquisas - que a gente chama de "perception study" com a comunidade de analistas e investidores do banco. Então nas divulgações de resultado trimestrais, a gente contrata uma empresa de consultoria e a gente pergunta várias coisas para essa empresa com relação ao processo de divulgação de informações e também o que eles acham do site do Banco, o que as pessoas gostariam de ver lá e não estão vendo... etc. Isso também é apoiado por pesquisas. Só que as pesquisas a gente a gente não faz com um intervalo muito curto de tempo para que elas não percam muito a efetividade. É importante que se faça com um intervalo maior de tempo para ver as tendências e a evolução, o que muda de um semestre para o outro e de um ano para o outro.

Sobre produtos customizados (por tipo de investidor)

Não existe esse tipo de produto, até porque a gente não pode dar "disclosure" diferenciado. Então o que a gente faz é disponibilizar um conjunto de informações, agora vai do interesse 
pessoal de cada um o quanto que ele se aprofunda e principalmente qual o lado que ele vai ter mais demanda - às vezes ele procura mais informações societárias, às vezes mais informações financeiras... então, a gente tem que estar atento a quem está fazendo a busca no site, mas a gente busca de maneira nenhuma, de modo algum diferenciar por pessoa.

E como vocês lidam com esse investidor que não tem conhecimento técnico?

Sim, a gente por email recebe muita pergunta "básica"... a gente procura explicar: primeiro ver se a informação tem no site, porque o site tem muita informação didática. A gente procura direcionar para o site e se não, a gente procura explicar...

Aí você primeiro dá o conceito para a pessoa reformular sua pergunta...

Exatamente. Mas, de qualquer maneira, qualquer pergunta que entra, seja da mais simples até a mais complexa, a gente responde todas.

Processo de geração de informação

7. Como ocorre o processo: análise diagnóstico da situação, planejamento, ação, feedback, mensuração (e reinício)? Quais as informações e formas de captação de informação de cada fase? Existe algum problema ou curiosidade em alguma fase?

8. Como é feito o armazenamento das informações? (organização para acesso e recuperação)

Vou te dar um exemplo de um material que temos aqui que é bastante ilustrativo: numa área de relações com investidores você tem basicamente dois tipos de informações: as informações que são recorrentes - que vão acontecer a cada período determinado. 0 período mais comum para uma RI é o trimestre: você publica trimestralmente as demonstrações financeiras e você precisa criar todo um conjunto de informações que acompanham e explicam as informações financeiras para o público ou não tão técnico ou não tão especializado, além das próprias demonstrações. Fora as informações que são periódicas e que se repetem, você tem as informações ou porque o Banco fez uma operação importante com alguma outra empresa, ou porque surgiu algum fato importante para $o$ mercado - uma legislação ou alguma outra coisa fora da rotina. Mesmo essas coisas fora da rotina aparecem nos relatórios trimestrais, mas precisamos dar um tratamento diferenciado para isso. Um exemplo do que a gente faz é: na nossa publicação trimestral, a contabilidade produz as demonstrações com aderência à legislação societária, à CVM e a toda essa parte de normas, mas é um documento bastante técnico e bastante restrito em termos do tipo de informação que entra. Como é um documento auditado pelo nosso auditor externo, existe 
todo um rigor para essa informação, mas muitas vezes isso aqui não é suficiente ou não é claro o suficiente para uma pessoa que não seja tão especializada ou mesmo não traz informações de negócios, informações gerenciais. Para acompanhá-lo, a gente faz o que a gente chama de "press release", que é uma publicação de mais ou menos trinta páginas e a gente explica o resultado numa linguagem um pouco mais acessível para o investidor, um pouco mais de negócios e colocando alguns destaques, algumas informações que não cabem numa demonstração financeira. Numa demonstração financeira você tem a informação seca: o lucro do período foi de tanto, a intermediação financeira foi de tanto, a carteira de crédito atingiu tanto. Numa explicação, a carteira de crédito foi de tanto porque aconteceram tais e tais eventos, ou o resultado da intermediação financeira foi de tanto porque impactado pelo aumento na taxa de juros combinado com alguma outra coisa ligada com a provisão para devedores duvidosos e você monta, então, a explicação do resultado. Você usa os números da contabilidade como suporte, mas você usa outras informações para suplementar e no fim fica uma informação talvez fácil de interpretar, mas que não dispensa a leitura das demonstrações financeiras, eu diria que ela acompanha e complementa. Aqui a gente dá destaque para alguns desses pontos que você levantou, por exemplo, quando a gente fala de análise diagnóstico da situação, planejamento, ação, feedback e mensuração quando a gente tem algum evento importante para relatar no trimestre, ele acaba fazendo parte do "press release". Vou dar um exemplo a gente fez uma operação grande no final do ano passado que foi a venda da participação do Banco na Credicard e no Orbital: então tem toda a situação - você faz uma análise-diagnóstica, você vê que tipo de informação vai ser mais relevante para o seu público alvo; a parte do planejamento, você procura criar textos ou tabelas ou gráficos que ilustram de maneira transparente para a pessoa o que está acontecendo, sem ser muito prolixo, você não pode ter um texto muito grande e encher a pessoa de tabelas porque você acaba não dando a informação que a pessoa precisa. $A$ parte da "ação", especificamente no caso da Credicard, uma semana antes do "press release" a gente fez um "conference call" e a gente deu destaque para as informações do Credicard. $O$ Feedback, a gente sempre procura saber dos investidores e dos analistas o que eles acharam e no caso de Relações com Investidores o feedback é bastante interessante, porque você tem um feedback natural - das pessoas te ligarem com dúvidas, perguntas e comentários e também os analistas "sell side", eles fazem relatórios recomendando ou não a compra do papel, então você tem um feedback também por aí, quer dizer, a opinião do mercado. O processo de divulgação de informações que seja transparente produz um feedback positivo e você consegue também avaliar, pelo tipo de reação que as pessoas no mercado, os analistas, têm sobre um evento societário se aquilo foi bem ou mal divulgado. 
Independente até da informação ter sido boa ou ruim, quer dizer, você tem empresas que reportam bons e maus trimestres, mas você pode ter uma empresa reportando um bom resultado trimestral e uma péssima informação para investidores e vice-versa. O que o investidor está querendo, no fim, é informação transparente para reduzir o risco e a incerteza dele com relação ao investimento que ele está fazendo. Quanto mais ele tem confiança que o resultado da empresa é inteligível, que a empresa não está escondendo nada dele, que ele consegue ter acesso às informações que produziram aquele resultado mais confiante ele vai ficar, mais baixo fica o grau de incerteza dele no investimento e com isso ele consegue precificar melhor aquele ativo. Então o feedback que a gente recebe é muito importante e a mensuração que se faz disso é constante. Todos os relatórios que a gente recebe, que são escritos sobre o Unibanco no mercado, a gente tem um processo de leitura, de fazer uma crítica, de entender o mecanismo de análise de cada analista daquele e até de saber se ele está usando premissas adequadas, se não está... se de repente ele está fazendo um cálculo que não corresponde muito à realidade etc. $A$ gente tenta não interferir nas opiniões de investimento das pessoas, porque opinião é uma coisa muito particular e dependente do julgamento de valor, mas em termos das premissas, a gente faz questão que as premissas sejam corretas. A gente faz um trabalho até de educação, por exemplo, se a gente pega um relatório com algum erro conceitual, a gente liga para a pessoa e explica, até que ela entenda. Agora, se ela não gostou do número, aí é uma questão pessoal dela, mas o importante é que ela saiba qual é o número.

E quanto do feedback direto, telefonemas e emails, existe uma freqüência maior de investidores individuais ou institucionais?

Quem se preocupa muito com as demonstrações financeiras e acompanha cada detalhe que é escrito, são os analistas e investidores - principalmente porque eles têm interesse financeiro diretamente envolvido ou estão recomendando investimento para pessoas que tem interesse em investimento em Bancos. Esses são os principais leitores, os primeiros que se manifestam com elogios, com dúvidas, com perguntas, com questionamentos. Agora, ao longo do tempo, e isso não está ligado diretamente à evolução do trimestre, a gente recebe diversas manifestações, principalmente por email, mas também por telefone, de gente "olha eu não entendi essa informação", "não achei muito claro", "onde eu encontro isso no site?"

E como é feito o armazenamento das informações? 
Pelo fato de ser um banco, o banco tem uma estrutura de tecnologia de informação muito desenvolvida, então a gente tem essa facilidade, a gente não tem nenhum problema de espaço no nosso website para as informações que já estão lá. Eventualmente a gente pode alugar provedores externos com esse fim, mas só pra colocar os arquivos mais antigos. Em termos de estrutura, de servidor e de espaço a gente não tem nenhum problema. Nosso site tem informações desde 1997, que é quando o banco começou a ter informações eletrônicas disponíveis para o público e a tendência é que a gente mantenha essas informações lá, até porque hoje em dia a disponibilidade do espaço não chega a ser um problema, eu acho que para nenhuma instituição - muito mais a organização da informação, a forma com que você deixa aquilo disponível faz a diferença do que a quantidade de informação. Principalmente agora que a maioria das empresas pode contar com o arquivamento da CVM e do SSI que são on line, nem a questão do espaço próprio é tão relevante: você pode dar acesso a todas as informações nos sites de terceiros. O mais importante é você conseguir explicar onde estão as informações e fazer com que as pessoas tenham acesso com facilidade, mas no nosso caso, a gente tem todas as informações guardadas com os nossos meios e bastante tranqüilidade com relação ao espaço que tem lá. Por exemplo, numa consulta que alguém tem que fazer nas demonstrações financeiras do ano 2000, não é que vai acontecer todo dia, se você for procurar estatística no site de consulta às demonstrações financeiras de 2000, vai ser muito baixo, mas é importante estar disponível porque quando alguém precisar, esta lá. O trabalho que a gente teria se tirasse do site e tivesse que mandar pontualmente para alguém por email: levantar a informação numa base de dados e passar, então deixar disponível é muito mais fácil, mais transparente. 'As vezes a pessoa tem interesse porque houve uma operação específica naquele período, ou quer lembrar de algum dado, ou está fazendo uma pesquisa, ou mesmo os jornalistas que precisam, às vezes, de informações históricas para fazer estatísticas... o importante é que a informação esteja disponível.

Meios de divulgação

9. Quais os canais que a instituição se utiliza? Site, Serviços terceirizados, jornais, Bovespa CVM, (mais algum?)

10. Como ocorre a mediação?

11. Qual a ordem de preferência do usuário? Como é medida? O que o Sr. pensa da obrigação legal de publicação em jornais? 
A gente usa como canal mais importante o site, a gente tem uma base de dados que tem um mailing grande de investidores, pessoas que tem interesse no Unibanco, então a gente manda emails para essa base com bastante freqüência, a gente também usa muito de conferências, reuniões, teleconferências semestrais, o jornal...

Vocês têm algum jornal específico?

Os jornais que o Banco tem como publicação obrigatória são o "Valor" e o "Diário Oficial do Estado". Então nesses, a gente tem que publicar todas as atas, convocações, publicações, enfim toda a parte de comunicação societária.

\section{E a CVM e a Bovespa?}

Hoje a CVM e a Bovespa compartilham um sistema chamado IPE, você alimentando o IPE, você está fornecendo informação para as duas casas. Para o mercado americano, a gente tem uma coisa similar que é o EDGAR, que é uma sigla do sistema deles, onde você faz o arquivamento e atende as exigências do SSI.

E o mailing? Vocês vão cadastrando as pessoas que entram em contato ou elas se cadastram pelo site?

Temos as duas opções. Por exemplo, se uma pessoa vem a uma reunião conosco e deixa um cartão, a gente pergunta se há interesse em entrar no mailing, se a pessoa concorda, as informações dela são colocadas no nosso database e ela passa a receber as informações.

Todo mundo que está no mailing recebe o convite para as teleconferências, mas o convite é público e fica disponível no website, quer dizer, qualquer pessoa que tenha interesse e acompanha a empresa, tem condições de acessar a conferência. A gente tinha até uma limitação antiga, quando a conferência era $100 \%$ por telefone gerava custos principalmente para quem não era de São Paulo. Hoje com a difusão da banda larga, a gente transmite a conferência por computador, pelo sistema de webcast, então a pessoa pode acessar pelo computador, ao vivo ou pelo replay e não tem custos de telefone.

A gente procura ser bastante abrangente neste aspecto.

Vocês têm alguma medida sobre o que o usurário, o investidor do Unibanco, prefere? A gente fez alguns estudos no passado e mais ou menos é o seguinte: todo mundo ou a maioria acessa o site de relações com investidores, só que muitos não se contentam com o que está no site e é até natural, de acordo com o nível de profundidade de informação que ele precisa. Por exemplo, mesmo os analistas investidores, o que eles fazem? Quando tem 
uma divulgação trimestral de resultados, ou quando estamos na iminência de ter uma publicação, ele busca essa informação no website, eles lêem, fazem as perguntas e nos ligam ou mandam email com perguntas mais específicas. Eles vão primeiro para o website $e$ pegam lá as demonstrações financeiras, press reliease e conference call, eles fazem 0 download, imprimem e analisam. A partir daí eles vêm com mais perguntas ou mais demanda de informação. Eu diria que o site é bastante universal, mesmo aqueles que não nos ligam, às vezes, vão no site e pegam perguntas, mas a maioria dos que nos ligam já passaram pelo site, já passaram pelo nível básico de informações. É claro que isso não é uma regra absoluta, tem pessoas que simplesmente pegam o telefone e ligam, mas o mais normal é as pessoas irem primeiro no website ou não encontram exatamente o que procuram e nos ligam perguntando onde está a informação ou ela conseguiu a informação que queria, só que ela quer uma informação adicional ali.

Então a gente pode concluir que o investidor com mais conhecimento é o que mais extrapola o site, que utiliza mais recursos que vocês disponibilizam, como ligar, como ter mais acessos e o investidor que é uma pessoa com menos conhecimento, o site já é muita coisa para ela... esse seria mais ou menos o perfil.

Eu não sei se é uma regra absoluta porque o fato do cara ter pouco ou menos conhecimento do que o outro não necessariamente determina se ele vai ligar mais ou menos. Acho que é uma questão de interesse, se a pessoa tem um investimento grande no Unibanco, mesmo que ele tenha pouco conhecimento por falta de tempo, limitação ou outra coisa, se ele tem investimento, é o dinheiro dele que está em jogo, ele vai ter bastante curiosidade, ele vai ligar bastante. Mas não tem uma regra muito especifica. Geralmente, aqueles que nos ligam com mais freqüência ou que são mais exigentes em quantidade de informação também são as "heavy users" do site - aqueles que freqüentam com mais assiduidade, que fazem download das informações novas que estão ali e que buscam estar sempre atualizados o máximo possível.

Esse é mais o perfil do investidor institucional mesmo, o investidor pessoa física está começando a acordar para essa área de investimento. E até como tem uma assessoria muito grande de bancos e de corretoras para a pessoa física, muitas vezes não é ele que liga, ele pede a informação para o analista da corretora ou para a pessoa que está assessorando ele no investimento - e quem liga para a gente é essa pessoa. O analista "sell side" é muito importante nesta hora porque muitas vezes o investidor não fala direto com as empresas, ele fala com uma corretora com a qual ele contrata os serviços de análises e essa corretora se encarrega de ligar para as empresas e de fazer todo o trabalho de análise, de comentar o 
desempenho da empresa e de passar para o cliente pessoa física. A gente até gostaria que ele viesse pessoalmente, mas geralmente ele pára em um certo ponto e a partir daí ele terceiriza, contrata alguém para fazer o trabalho para ele.

Existem alguns trabalhos e entrevistas de profissionais de RI dizendo que há um interesse das empresas em aumentar o número de investidores individuais, por eles serem mais permanentes em seus investimentos. O Unibanco tem algum projeto ou campanha com esse objetivo?

Em termos de liquidez, o Unibanco tem uma fase bastante marcada que está acontecendo agora, desde que ele fez a oferta global em 1997, a maior parte da liquidez do banco estava na bolsa de Nova Iorque. A gente tinha quase $90 \%$ das ações negociadas em bolsa em Nova Iorque. De uns dois anos para cá, com duas ofertas secundárias de grande porte que o banco fez, na verdade foram grandes acionistas institucionais que venderam suas posições e as ofertas foram canalizadas para a Bovespa, a gente tem feito um movimento grande de tentar trazer o máximo de liquidez para a bolsa de São Paulo. A gente foi muito bem sucedido nisso, se você acompanhar nossa evolução de liquidez nesse período, ela é muito satisfatória e nosso objetivo é fazer parte do índice Bovespa. A gente já faz parte do IBRX desde o ano passado e agora a gente quer incluir Bovespa e tudo indica que esse ano isso deve acontecer. Então num primeiro momento, a gente está buscando que os investidores brasileiros tenham interesse no papel. $O$ fato de pertencer a índices de bolsa, o fato de ter uma liquidez aqui dá mais segurança para o investidor e em um segundo momento naturalmente a gente espera que isso desperte o interesse do investidor pessoa-física pelo papel. Já existe um interesse bastante razoável, a gente percebeu quando a gente fez as duas ofertas secundárias que houve um grande volume de pessoas físicas buscando o papel e as ofertas tiveram também um direcionamento para pessoa-física. Elas foram vendidas, como tem acontecido com muitas operações recentes no mercado de capitais, para pessoasfísicas e teve uma resposta muito boa. É um investidor que realmente se identifica com o papel, que fica mais tempo, que resiste mais a vender o papel... a gente sabe que é um bom investidor e a gente sabe que esse tipo de investidor brasileiro vai aumentar naturalmente à medida que aumentar nosso "float" aqui no mercado doméstico. Então, a gente fincando firmemente nossa saída aqui na Bovespa a gente acha que vai atingir o institucional brasileiro e ficando o papel mais conhecido me Bolsa, isso atrai também o investidor pessoa-física.

O que o Sr. pensa da obrigação legal de publicação em jornais? 
Olha, é um custo. Mas, dada a magnitude de outros custos que as empresas brasileiras são submetidas, não é um custo tão alto assim.

Para você pedir ao seu investidor que imprima um informe com 70 páginas na casa dele em sua impressorinha jato de tinta, realmente dá um custo muito alto para a pessoa e nem sempre ela tem essa disponibilidade, muitas pessoas tem computador em casa, mas não tem impressora... Então eu acho que o custo para a empresa de pagar publicação em jornal, mas que a pessoa possa ter a publicação em um caderno em que ela possa pôr em uma pasta e carregar, é muito mais prático do que dar o ônus da pessoa imprimir essa informação. E a gente tem, no Brasil, outros custos associados ao custo país que são muito mais altos que este. Pode soar um pouco arcaico publicar em jornal, mas eu vejo muito analista chegando aqui com informações impressas de jornal. Eu acho que facilita muito para a pessoa-física principalmente, é muito mais prático comprar o jornal que tem a publicação financeira que imprimir em casa.

Vocês informam no site a edição do jornal em que está a publicação?

Na verdade a data de publicação já fica no calendário do site desde muito tempo antes, então as pessoas já sabem quando vai ser publicados e os jornais de publicação obrigatória também são amplamente conhecidos, que no caso do banco é o Valor e também o Diário Oficial do Estado.

Ruídos e Barreiras

12. Quais as principais barreiras internas ao trabalho de RI? As soluções são padronizadas?

13. Quais os entraves de comunicação interna mais comuns?

14. Quais as barreiras de recuperação da informação?

As informações são produzidas na Contabilidade, o diretor de relações com investidores estatutário que está na CVM é o chefe da Contabilidade também e da Controladoria e a pessoa dedicada somente a relações com investidores, que é o nosso Diretor adjunto trabalha na mesma sala com o chefe da contabilidade, sem falar que as pessoas da Controladoria, como de Contabilidade e as de Relações com Investidores se reportam ao CFO do Banco, então é a mesma estrutura. São pessoas que trabalham muito próximas, a gente não tem qualquer dificuldade de acesso às informações contábeis. Agora, barreiras de informação, elas sempre existem e eu acho que elas estão mais presentes na parte de negócios e, às vezes, são barreiras não intencionais... às vezes é o fato de a pessoa estar desenvolvendo um produto novo ou de ter uma área cuidando de um projeto específico. Aí 
você precisa fazer um trabalho de networking muito próximo. Às vezes a pessoa está fazendo um trabalho muito importante para o Banco, mas ela não sabe da importância e a informação fica presa em um ambiente mais restrito. Isso é natural em qualquer empresa grande. O que a gente faz aqui é buscar trazer essa pessoa para o nosso convívio, explicar para elas o que a gente faz aqui e principalmente incutir a necessidade de reportar também para o Relações com Investidores todas as coisas relevantes que acontecem entre as áreas do Banco. No Banco, de alguns anos para cá, está muito presente na cabeça dos principais executivos a cultura de mercado de capitais, eu acho que já existe uma cultura bastante disseminada de pensar assim: "bom, quando eu estou fazendo alguma coisa relevante aqui, também é relevante para a área de relações com investidores". Agora, é claro que sempre acontecem operações ou novos produtos e a gente precisa ir na área de negócios e saber o que está acontecendo. Então depende muito de networking, de cultivar um bom relacionamento com as áreas, principalmente as áreas não financeiras. Também acho que há uma questão de feedback, acho que não é sempre ir na área e pedir informações e nunca explicar o que vai ser feito com aquilo. Se você volta e diz a pessoa, "isso aqui foi publicado no press release", "Isso foi publicado no jornal assim" "teve repercussão"... Você cria comprometimento, você traz a pessoa para o seu lado.

Então vocês têm também um papel educativo?

Acho que tem um trabalho interno de relações com investidores, que é você explicar para as áreas do Banco qual é a importância do RI, porque o que alguém está desenvolvendo ali na ponta de negócios importa para relações com investidores e também de dar para as áreas a repercussão que teve. Um exemplo, um novo produto que foi lançado no ano passado na área de captação, a gente colheu diversas informações da área de negócios que estava trabalhando esse produto e ao mesmo tempo foi importante passar de volta para eles o que o mercado achou, qual foi a reação dos investidores com relação ao produto que foi lançado. Tem que ser um canal de duas vias, não pode ser via única, senão você vai perdendo o comprometimento do outro lado também. É natural, a pessoa tem o dia a dia dela, ela ganha o bônus dela pelo que gera de negócios e não pelo volume de informações que ela passa para o RI, então você precisa criar um comprometimento para tirar a pessoa do que ela está fazendo e passar informações para você e criar boa vontade.

Tem alguma barreira na recuperação da informação?

Quanto ao site não. Mas em questão de recuperação da informação internamente... a gente, quando tem informações mais antigas para solicitar das áreas, é natural que elas peçam um 
pouco mais de tempo, porque às vezes aquilo está num backup, alguma coisa assim. Para acessar um dado do começo do ano 2000 de uma área de negócios, é possível que essa pessoa me fale "olha, eu vou precisar de um tempo para achar essa informação", pelo fato de não estar mais ali no dia a dia. Mas, no site, dificilmente tem algum problema, até porque tem o backup para tudo, então se sumir alguma coisa, a gente coloca de volta.

Acréscimo de valor

15. Essa instituição mede o acréscimo de valor que o RI traz para ela na visão dos usuários? Há algum estudo?

16. A valorização financeira da empresa pode ser relacionada ao crescimento do programa do RI?

A quantificação disso é muito difícil porque afetando o preço do papel em bolsa tem muita coisa. Então, às vezes, você tem os fatores macroeconômicos do país, que são muito relevantes e também são condicionados pelos fatores econômicos do resto do mundo, você tem informação pertinente ao setor de atuação da sua empresa, você tem uma série de contingências da própria empresa em que está atuando. Tem várias coisas que interagem e interferem, é muito difícil dizer que determinada empresa é mais ou menos valorizada apenas por conta de relações com investidores ou por disclosure. O que a gente sabe é que, mensuração é um pouco difícil, mas você pode tentar fazer alguns trabalhos analíticos para entender um pouco melhor. É claro que a empresa que é transparente, que o investidor tem confiança nas informações que vêm da empresa, é mais bem valorizada pelo mercado.

Um dos fatores que contribuem para depreciar o preço de uma ação na empresa em bolsa é a quantidade de incerteza relacionada àquele investimento. A partir do momento em que você consegue diminuir o nível de incerteza em relação a um ativo, naturalmente você consegue atribuir um preço melhor a esse ativo. A incerteza é um fator de desconto no preço do papel, à medida que você vai removendo as incertezas, você vai removendo um dos fatores de desconto no preço do papel até chegar a ponto de que aquilo deixa de ser um fator inibidor para o investidor. Quanto mais transparente for a empresa, quanto mais tranqüilo for para a pessoa saber o que está acontecendo com o investimento dela, melhor aquilo vai ser para o preço da ação. Um site de relações com investidores muito abrangente, um trabalho de relações com investidores que busca falar com o maior número possível de pessoas, ser o mais esclarecedor possível, ter uma quantidade maior de informações acaba sendo um fator que melhora o preço da empresa, é claro que tem um custo, mas o custo de manter uma área de relações com investidores eficiente e focada é infinitamente 
compensado pelo benefício que isso traz para o papel. É claro que a empresa pode ter um bom RI e ter um resultado financeiro ruim ou inesperado e isso acaba afetando também o preço. Ao mesmo tempo, a empresa pode ir muito bem, o relações com investidores ir muito bem, mas um fator econômico qualquer pode afetar o preço da ação e assim sucessivamente, tem vários fatores que interferem. Como dizer... é a mesma coisa como se fosse um selo de qualidade: não que a informação boa necessariamente agregue valor, mas a informação ruim certamente tira valor. Mas o trabalho de relações com investidores não pode maquiar a realidade, tem que ser uma vitrine de uma loja bem transparente, 0 investidor tem que ter uma visão bastante clara do que está ali dentro. O trabalho de transparência e de fidelidade da informação é muito importante.

Tem mais alguma coisa que vocês queiram acrescentar?

Há uma frente que hoje tem sido muito explorada na área de RI. É o seguinte, você não precisa necessariamente diferenciar ou discriminar a informação que você dá para um e para outro, você tem é que conhecer o seu cliente, quem está te pedindo a informação para você. É completamente diferente você ter um site que dá informação diferenciada para um e para outro e uma área que dá informação diferenciada para um e para outro de você entender a necessidade de seu cliente e dar uma informação customizada para ele. Então eu acho que um interesse das áreas de relações com investidores em geral ultimamente é conhecer o público que está cuidando e você ter informações para o institucional, para a pessoa-física, para as agências de rating etc. Em nenhum momento, isso é diferenciação de informação, mas é você ter uma solução que se adeqüe mais à necessidade de cada um. Por exemplo, se eu faço um press release que seja para um público mais amplo, eu não posso ser tão técnico quanto se eu estivesse falando com os contadores, e vice-versa. O que é que isso é diferente da discriminação? Se um médico tem acesso a um press release de duas páginas explicando o resultado e ele quiser ter o balanço na mão dele, ele vai ter. Eu não estou discriminando, eu só estou dando a informação que eu acho que tem mais a ver com a demanda dele. É diferente de eu dar uma informação para um e dar uma informação melhor para outro porque ele é mais técnico, mais avançado na análise que faz... e eles também não querem saber de informação que não se adeqüe ao perfil deles. $O$ analista não gosta de receber uma coisa muito superficial e o profissional liberal, uma pessoa que comprou ação do Banco como pessoa física, às vezes, quer receber um informe de duas páginas só para saber como está a empresa da qual ele comprou a ação. A gente precisa ter no site, nas publicações que a gente faz, todo tipo de nível de informação e acho que a 
inteligência do negócio de RI está em direcionar, para cada publico alvo, aquilo que ele está demandando. É completamente diferente de você achar que a pessoa precisa de uma informação e negar para ela outro tipo de informação.

Toda vez que alguém liga para a gente ou manda email, e que faz parte da nossa base de dados, a gente vai guardando o histórico dele no nosso banco de dados, e no fim a gente acaba sabendo se essa pessoa tem mais interesse por uma informação financeira ou uma informação mais qualitativa etc. Agora, o grande interesse das áreas de RI é aumentar um pouco a escala em que isso é feito. O que, em nenhum momento é negar informações, mas é você dar aquilo que o investidor está querendo e falar "olha, se você quiser o resto, está aqui disponível, mas eu acho que o que você quer é isso aqui". Aí você tem que ir atrás do feedback, saber se a pessoa se agradou, se era aquilo que ela queria mesmo, que tipo de crítica ela tem ao material - está muito extenso, muito curto, muito profundo ou não. 


\section{Resultados de pesquisas anteriores}

\section{GUAGLIARDI, José Rafael. A evidenciação de informações em companhias abertas -}

um estudo exploratório. Tese (Doutorado em Controladoria e Contabilidade) -

Faculdade de Economia, Administração e Contabilidade. São Paulo: Universidade de São Paulo, 1987.

Sua pesquisa empírica foi aplicada ao segmento "agentes do mercado de ações investidores ou intermediários" - especificamente, as corretoras com operação na Bolsa Bovespa e o levantamento abrangeu os seguintes temas:

- Quais as demonstrações contábeis são mais utilizados para análise de uma empresa;

- Quais informações são extraídas destes documentos para as decisões de investimento;

- Que outras fontes de informações são utilizadas além das demonstrações contábeis;

- Se as companhias abertas deveriam publicar dados projetados para o ano subseqüente, entre outras.

Os principais resultados de sua pesquisa são:

\begin{tabular}{|l|l|l|l|l|l|l|}
\hline & DT & DB & DP & CP & CB & CT \\
\hline $\begin{array}{l}\text { Mudanças legais e econômicas afetam a comparabilidade } \\
\text { p.157 }\end{array}$ & 2 & & 2 & 3,9 & 23,5 & 68,8 \\
\hline $\begin{array}{l}\text { cias abertas deveriam publicar dados projetados p.158 sim } \\
62,7 \% \text { e não } 37,3 \%\end{array}$ & & & & & & \\
\hline $\begin{array}{l}\text { relatórios administrativos suficientemente esclarecedores } \\
\text { p.161 }\end{array}$ & 11,8 & 9,8 & 27,5 & 45,1 & 5,9 & \\
\hline $\begin{array}{l}\text { As informações do Relatório da Administração podem gerar } \\
\text { vieses na análise de prospecção p. } 161\end{array}$ & 3,9 & 2 & 17,6 & 39,2 & 21,6 & 15,7 \\
\hline $\begin{array}{l}\text { Os diretores de relações com o mercado têm tido } \\
\text { desempenho satisfatório em suas funções p.162 }\end{array}$ & 5,9 & 13,7 & 17,6 & 37,3 & 23,5 & 2,0 \\
\hline $\begin{array}{l}\text { As Cias abertas têm dado igual oportunidade ao mercado } \\
\text { sobre informações relevantes p. 162 }\end{array}$ & 21,6 & 19,6 & 19,6 & 31,4 & 5,9 & 2 \\
\hline $\begin{array}{l}\text { O parecer da auditoria independente é tão importante } \\
\text { quanto os demonstrativos contábeis para efeito de análise } \\
\text { p.165 }\end{array}$ & 5,9 & 7,8 & 7,8 & 25,5 & 19,6 & 31,4 \\
\hline
\end{tabular}

Legenda:

$$
\begin{aligned}
& \text { DT }=\text { discordo totalmente } \\
& \text { DB }=\text { discordo bastante } \\
& \text { DP }=\text { discordo um pouco } \\
& C T=\text { Concordo totalmente } \\
& C B=\text { concordo bastante } \\
& C P=\text { concordo um pouco }
\end{aligned}
$$

Além de traçar o perfil dos profissionais de investimento, como usuários, a tese ainda apresenta um novo modelo para uma demonstração contábil que pudesse ser mais útil para este usuário. 


\section{Publicação legal de Demonstrações contábeis}

A Lei das Sociedades por Ações nº 6.404 de 15 de dezembro de 1976, conhecida como lei societária, apresenta:

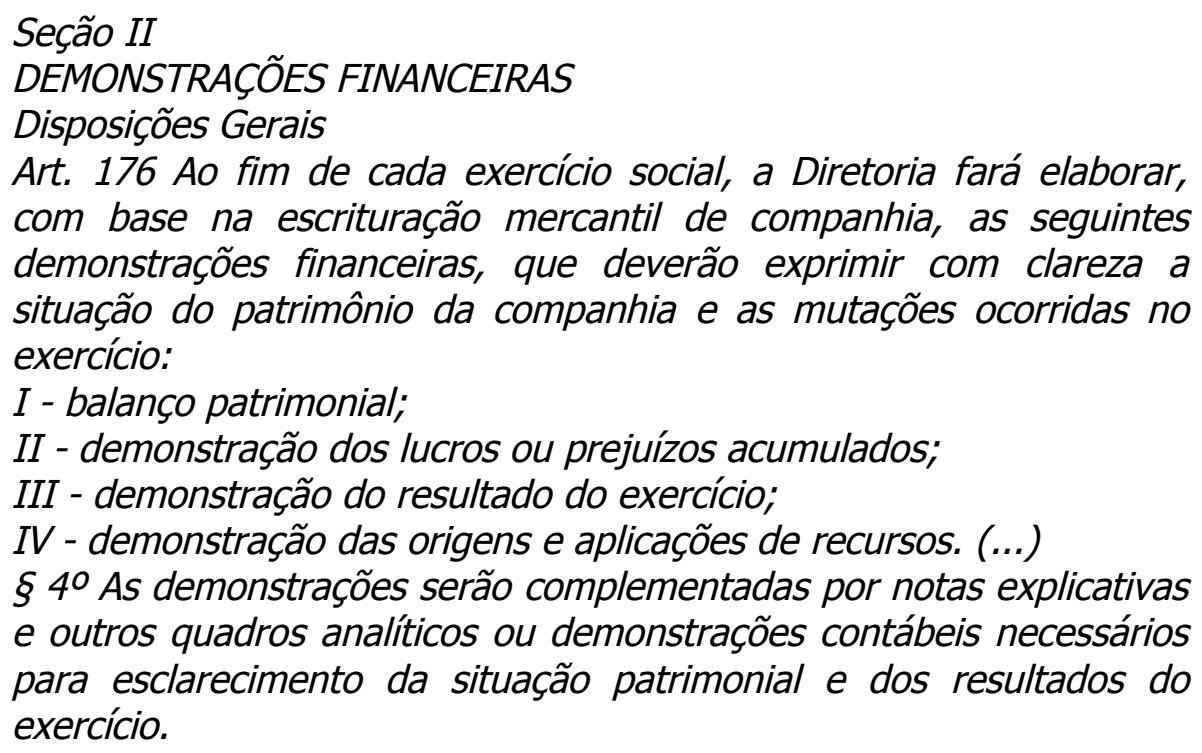

Dentre os relatórios não obrigatórios, destacam-se a Demonstração do Fluxo de Caixa e a Demonstração do Valor Adicionado. O anteprojeto de lei que reformula a Lei das S.A. apresenta, como uma das alterações, a inclusão destes dois relatórios como obrigatórios e a exclusão da Demonstração das Origens e Aplicações de Recursos. O conteúdo gráfico e semântico de cada uma dessas demonstrações, citadas no anteprojeto, será resumidamente exposto a seguir.

\section{a) Balanço Patrimonial}

Apresenta o saldo monetário dos valores constituintes do patrimônio da empresa em uma data específica, de forma estática (os saldos válidos para aquela data), sintética (contas agrupadas) e ordenada (critérios de classificação), segundo Marion (2003).

As demais demonstrações contábeis são aberturas dos componentes dessa. Ou seja, o balanço condensa dados que são mais bem explicados em outras peças. Essa relação entre as demonstrações contábeis costuma ser parte do trabalho dos analistas, de uma forma simplista, quanto melhor se sabe verificar dados equivalentes entre as demonstrações, mais se pode opinar sobre a qualidade da elaboração. 


\begin{tabular}{|l|l|}
\hline balanço patrimonial (estrutura básica) \\
\hline Ativo & Passivo \\
\hline CIRCULANTE & CIRCULANTE \\
Atividades Usuais & NÃO CIRCULANTE \\
Atividades não usuais & Exigível a longo prazo \\
NÃO CIRCULANTE & Resultados não realizados \\
Realizável a longo prazo & \\
Investimentos & PATRIMÔNIO LíQUIDO \\
Imobilizado & Capital realizado \\
em operação & Reservas de Capital \\
em arrendamento & Ajustes de avaliação \\
para futura operação & Reserva de lucros \\
Intangível & $(-)$ Aç̃̃es em tesouraria \\
Diferido & $(-)$ Prejuízos acumulados \\
\hline
\end{tabular}

Fonte: Marion, 2003, p.15

Cabe descrever alguns itens da terminologia contábil, para que se possa entender o que representam essas contas e grupos acima dispostos.

O Ativo engloba todas as aplicações de recursos em direitos e em bens que estão à disposição da empresa e dos quais ela tenha a propriedade ou o direito contratual de se tornar proprietária futuramente. (MARION, 2003 p.16).

Dito de outro modo, o que a empresa possui (dinheiro, estoques, instalações, máquinas, equipamentos, veículos, imóveis etc.) e o que ela detém o direito a receber ou utilizar-se (contas a receber por vendas a prazo, aluguéis pagos adiantadamente, seguros, direito a restituição de impostos etc.) compõem o ativo.

Para o International Accounting Standards Board (IASB),

O benefício econômico futuro embutido em um ativo é o potencial de contribuir, direta ou indiretamente, ao fluxo de caixa ou equivalente de caixa da entidade. Poderá ser um ativo potencial produtivo, que é parte das atividades operacionais da entidade. Poderá também ter a forma de conversibilidade em caixa ou equivalentes de caixa ou um poder de reduzir as saídas de caixa, da mesma maneira que um processo industrial alternativo reduz os custos de produção.(IASB, 2001, p. 55).

E ainda

Os benefícios econômicos futuros de um ativo podem fluir para a entidade de diversas maneiras. Por exemplo, um ativo pode ser:

(a) usado isoladamente ou em conjunto com outros ativos na produção de mercadorias e serviços a serem vendidos pela entidade;

(b) trocado por outros ativos;

(c) usado para liquidar um passivo; ou

(d) distribuído aos proprietários da entidade. (IASB, 2001, p. 55). 
A divisão entre "circulante" e "não circulante" significa o que vencerá nos próximos 12 meses e o que vencerá após esse prazo, respectivamente.

O Passivo "representa as fontes de recursos das quais a empresa lançou mão para financiar os valores aplicados no Ativo." (MARION, 2003 p. 23). Esse grupo concentra as dívidas ou obrigações da empresa (contas a pagar a fornecedores, bancos, tributos a pagar ao governo, salários aos funcionários, encargos trabalhistas a vencer etc.).

Uma característica essencial de um passivo é que a entidade tem uma obrigação. Uma obrigação é um dever ou responsabilidade de agir ou fazer de uma certa maneira. As obrigações poderão ser legalmente exigíveis em conseqüência de um contrato ou requisitos estatutários.(...)

A extinção de uma obrigação presente pode ocorrer de diversas maneiras, por exemplo:

(a) pagamento em dinheiro;

(b) transferência de outros ativos;

(c) prestação de serviços;

(d) substituição da obrigação por outra; ou

(e) conversão da obrigação em capital.(IASB, 2001, p. 56).

O Patrimônio Líquido se constitui dos "recursos próprios da empresa, trazidos pelos sócios (capital) ou gerados pelas operações sociais (lucros e reservas)". (Marion, 2003 p. 25). Nesse grupo de contas estão, principalmente, os recursos investidos pelos proprietários no início da empresa e os originados pela venda de ações (inclusão de novos investidores).

Portanto, ao ler o balanço patrimonial, é possível fazer a leitura das seguintes questões: os bens que a empresa dispõe (Ativo), o quanto ela deve (Passivo) e a diferença entre os dois (Patrimônio Líquido). Mais detalhadamente, pelo Ativo pode-se observar a distribuição dos investimentos da empresa - o quanto em dinheiro e equivalentes, o quanto em estoques, o valor das instalações fabris, imóveis, veículos etc., e a evolução desses investimentos comparando-se a períodos anteriores. Sobre o Passivo, conhecer o endividamento da empresa, para quais tipos de emprestadores e a proximidade dos pagamentos, assim como, comparar a evolução das dívidas entre períodos.

\section{b) Demonstração do Resultado do Exercício}

Despertando um interesse especial nos usuários que possuem certo conhecimento do domínio, essa demonstração é a que exibe o resultado (lucro ou prejuízo) das atividades do período. 
Demonstração do Resultado do Exercício do período $\mathrm{x}$

Receita Bruta

(-) Deduções da receita bruta (devoluções, cancelamentos, abatimentos e tributos)

= Receita líquida

(-) Custo da Receita líquida

$=$ Lucro Operacional Bruto

$( \pm)$ Resultados Operacionais

receitas financeiras

outras receitas e ganhos (operacionais)

resultado das participações societárias

despesas administrativas

despesas com vendas

despesas financeiras

prêmio na emissão de debêntures (já realizado)

juros sobre o capital próprio

ajustes a valor presente

= Resultado Operacional Líquido

( \pm ) Resultados não operacionais

ganhos e perdas em operações descontinuadas

doações e subvenções para investimento (já realizadas)

Itens extraordinários

$=$ Resultado Antes das Participações

(-) Participações de terceiros

imposto de renda

empregados e diretores

debêntures e partes beneficiárias

= Resultado Líquido do Exercício

$( \pm)$ ajustes de exercícios anteriores

= Resultado Líquido do Exercício Ajustado

Adaptado de Marion, 2003 p.33

Trata-se de uma demonstração de formato coluna (vertical), na qual das receitas (vendas) efetuadas vão sendo diminuídos os diversos gastos.

Além disso, tal demonstrativo procura mostrar, em seqüência lógica e ordenada, todos os fatores que influenciaram, para mais ou para menos, o resultado do período. Ele se torna, assim, valioso instrumento de análise econômico-financeira e preciosa fonte de informações para a tomada de decisões administrativas. (MARION, 2003, p.32).

Nem todas as empresas apresentam a complexidade de atividades exposta nessa demonstração exemplificada, porém essa dá uma visão do nível de abertura de valores nela exibidos.

\section{c) Demonstração das Mutações do Patrimônio Líquido}


Essa peça contábil apresenta todas as modificações ocorridas nas contas que estão no grupo do balanço patrimonial denominado "patrimônio líquido", desde a última elaboração do conjunto de demonstrações até o momento. "Essa demonstração mostra com clareza o fluxo de uma conta para outra, indicando a origem e o valor de cada acréscimo ou diminuição no Patrimônio Líquido durante o exercício." (MARION, 2003, p.51).

\begin{tabular}{|c|c|c|c|c|c|c|c|c|}
\hline \multicolumn{9}{|c|}{ Demonstração das Mutações do Patrimônio Líquido do exercício findo em 31/12/0x } \\
\hline \multirow[b]{2}{*}{ Descrição } & \multirow[b]{2}{*}{$\begin{array}{l}\text { capital } \\
\text { realizado }\end{array}$} & \multirow{2}{*}{$\begin{array}{l}\text { Reserva } \\
\text { s de } \\
\text { capital } \\
\text { Ágio na } \\
\text { emissão } \\
\text { de ações }\end{array}$} & \multicolumn{2}{|c|}{ Reservas de lucros } & \multirow[b]{2}{*}{$\begin{array}{l}\text { Ajuste de } \\
\text { Avaliação } \\
\text { Patrimonial }\end{array}$} & \multirow[b]{2}{*}{$\begin{array}{l}\text { Lucros } \\
\text { Acumu- } \\
\text { lados }\end{array}$} & \multirow[b]{2}{*}{$\begin{array}{l}\text { Lucros } \\
\text { a Desti- } \\
\text { nar }\end{array}$} & \multirow[b]{2}{*}{ Total } \\
\hline & & & $\begin{array}{l}\text { Reserva } \\
\text { legal }\end{array}$ & $\begin{array}{l}\text { Reserva } \\
\text { de } \\
\text { Lucros } \\
\text { para } \\
\text { expansão }\end{array}$ & & & & \\
\hline Saldos iniciais & & & & & & & & \\
\hline Movimentações & & & & & & & & \\
\hline Saldos finais & & & & & & & & \\
\hline
\end{tabular}

Adaptado de Marion, 2003, p.56.

Todas as contas representadas na primeira linha subdividida da tabela fazem parte do patrimônio líquido, e essa demonstração visa à abertura da movimentação de cada uma individualmente, o que não pode ser observado no balanço patrimonial.

\section{d) Demonstração dos Fluxos de Caixa}

Talvez a demonstração contábil de mais difícil elaboração, essa peça tem o propósito de mostrar detalhes da formação do saldo do caixa (desde quanto era no balanço patrimonial mais antigo e quanto está no último). Mais claramente, ela indica a origem e a aplicação das disponibilidades (dinheiro e equivalentes) que passaram pelo caixa da empresa no período coberto pela demonstração.

"Por meio da Demonstração dos Fluxos de Caixa, podem ser avaliadas as alternativas de investimentos $e$ as razões que provocaram as mudanças da situação financeira da empresa, as formas de aplicação do lucro gerado pelas operações e até mesmo os motivos de eventuais quedas no capital de giro." (MARION, 2003 p.57). 
Há dois métodos principais de elaboração, o direto (exemplificado a seguir) e o indireto.

d) Demonstração dos Fluxos de Caixa - método direto

Fluxo de caixa proveniente:

1. Das atividades operacionais

Recebimentos de:

clientes

receitas financeiras

dividendos de coligadas e controladas

devedores diversos

Pagamentos a:

fornecedores de estoques

impostos e contribuições

salários e encargos

devedores diversos

= Acréscimo de caixa originado das atividades operacionais

2. Das atividades de investimentos

Receita da venda de:

imobilizado

investimentos permanentes

Aquisições de:

imobilizado

investimentos permanentes

$=$ Aumento/Diminuição de caixa originado das atividades de investimentos

3. Das atividades de financiamento

integralização de capital

novos empréstimos e financiamentos

amortização de empréstimos e financiamentos

dividendos pagos

= Aumento/Diminuição de caixa originado das atividades de financiamento

Resumo

Saldo inicial

+ Acréscimo/redução de caixa no período $(1+2+3)$

= Saldo final

Adaptado de Marion, 2003 p.66

Esse demonstrativo é muito popular na América do Norte, passando a integrar o projeto de lei já citado, em substituição à demonstração das origens e aplicações de recursos, que é a atual exigência legal brasileira. 


\section{e) Demonstração do Valor Adicionado}

Essa demonstração apresenta "o quanto de valor a empresa adiciona aos insumos adquiridos por ela e sua distribuição aos elementos que contribuíram para essa adição." (MARION, 2003, p.69). O mesmo autor conceitua o "valor adicionado" como: "a diferença entre o valor da produção e os consumos intermediários (que representam compras a outras empresas) em certo período mensurável, que nada mais é do que a definição utilizada pela Economia. Pode-se utilizar o mesmo conceito de aplicação empresarial também para a aplicação em uma área ou divisão da empresa ou, ainda para produtos." (MARION, 2003, p.70).

É um demonstrativo bastante considerado na Europa por seu aspecto social, tanto no contexto da empresa (microeconômico) quanto para a macroeconomia, pois o somatório dos valores adicionados de um país deve coincidir com seu produto interno bruto (PIB). O modelo padrão está apresentado a seguir.

\begin{tabular}{|l|l|}
\hline Demonstração do valor adicionado - empresa X exercício de 200x \\
\hline $\begin{array}{l}\text { Receita operacional } \\
\text { Vendas de mercadorias, produtos e serviços }\end{array}$ & VENDAS \\
\hline $\begin{array}{l}\text { Menos Insumos adquiridos de terceiros } \\
\text { matérias primas } \\
\text { custo da mercadoria vendida } \\
\text { custo dos serviços prestados } \\
\text { serviços de terceiros e outros }\end{array}$ & $\begin{array}{l}\text { '- CMV } \\
\text { - MATERIAIS, -ENERGIA, } \\
\text { Igual= valor adicionado bruto }\end{array}$ \\
\hline $\begin{array}{l}\text { Menos - retenções } \\
\text { depreciações } \\
\text { amortizações e } \\
\text { exaustão }\end{array}$ & = VAB \\
\hline Igual= valor adicionado líquido & -DEPRECIAÇÕES \\
\hline $\begin{array}{l}\text { Mais + valor adicionado recebido em transferências } \\
\text { receitas financeiras e } \\
\text { resultado de equivalência patrimonial }\end{array}$ & = VAL \\
\hline Igual = valor adicionado total a distribuir & + OUTRAS RECEITAS \\
\hline $\begin{array}{l}\text { distribuição: Pessoal e encargos } \\
\text { Impostos, taxas e contribuições } \\
\text { Juros e aluguéis } \\
\text { Juros sobre capital próprio e dividendos } \\
\text { Lucro reinvestido }\end{array}$ & VAT \\
\hline TOTAL DO VALOR ADICIONADO (= VAT) & \\
\hline $\begin{array}{l}\text { Adaptado de Marion, 2003 p.80 } \\
\text { - DISTRIBUIÇÕES }\end{array}$ \\
\hline
\end{tabular}




\section{Comissão de Valores Mobiliários - CVM}

É uma entidade autárquica em regime especial, vinculada ao Ministério da Fazenda, criada pela Lei no 6.385/76, com autoridade administrativa independente, ausência de subordinação hierárquica e administrada por um Presidente juntamente com quatro Diretores, nomeados pelo Presidente da República, aprovados pelo Senado Federal, com mandatos fixos de 5 anos. Também possui autonomia financeira e orçamentária e sua diretoria é órgão de deliberação colegiada.

\section{Objetivos}

A CVM deve exercer suas atribuições com a finalidade de assegurar 0 funcionamento eficiente e regular dos mercados da bolsa e de balcão e proteger os investidores do mercado contra:

•emissões irregulares de valores mobiliários;

-atos ilegais de administradores e acionistas controladores das companhias abertas, ou de administradores de carteira de valores mobiliários.

-uso de informação relevante não divulgada no mercado de valores mobiliários.

Evitar ou coibir modalidades de fraude ou manipulação destinadas a criar condições artificiais de demanda, oferta ou preço dos valores mobiliários negociados no mercado e assegurar o acesso do público a informações sobre os valores mobiliários negociados e as companhias que os tenham emitido.

\section{Atribuições}

Compete à CVM fiscalizar e disciplinar:

-A emissão e distribuição de valores mobiliários no mercado;

-A negociação e intermediação no mercado de valores mobiliários e no mercado de derivativos;

-A organização, funcionamento e operações das bolsas de valores e de mercadorias e futuros;

-A administração de carteiras e a custódia de valores mobiliários;

-A auditoria das companhias abertas;

- Os serviços de consultor e de analista de valores mobiliários.

Para isso, a instituição exerce as seguintes funções:

a)Fiscalizatória; 

b)Regulatória;
c)Registrária;
d)Consultiva;
e)De Fomento.

\section{a) Função Fiscalizatória}

A CVM tem poderes para examinar e extrair cópias de registros contábeis, livros ou documentos das pessoas naturais e jurídicas que integram o sistema de distribuição de valores mobiliários; das companhias abertas e demais emissoras de valores mobiliários e, quando houver suspeita fundada de atos ilegais, das respectivas sociedades controladoras, controladas, coligadas e sociedades sob controle comum; dos fundos e sociedades de investimento; dos auditores independentes; dos consultores e analistas de valores mobiliários; de outras pessoas quaisquer, naturais ou jurídicas, quando da ocorrência de qualquer irregularidade a ser apurada nos termos do inciso $\mathrm{V}$ deste artigo, para efeito de verificação de ocorrência de atos ilegais ou práticas não eqüitativas.

Além disso, ela pode intimar as pessoas acima a prestar informações, ou esclarecimentos, sob cominação de multa; requisitar informações de qualquer órgão público, autarquia ou empresa pública; determinar às companhias abertas que republiquem, com correções ou aditamentos, demonstrações financeiras, relatórios ou informações divulgadas; apurar, mediante processo administrativo, atos ilegais e práticas não eqüitativas de administradores, membros do conselho fiscal e acionistas de companhias abertas, dos intermediários e dos demais participantes do mercado; aplicar aos autores das infrações indicadas no item anterior as penalidades previstas no art. 11 da Lei no 6.385/76, sem prejuízo da responsabilidade civil ou penal.

No exercício da competência fiscalizatória, a CVM deve fiscalizar e inspecionar as companhias abertas, dada prioridade às que não apresentem lucro em balanço ou às que deixem de pagar o dividendo mínimo obrigatório (art. 8 o, inciso V, da Lei no 6.385/76); e dar prioridade às infrações de natureza grave, cuja apenação proporcione maior efeito educativo e preventivo para os participantes do mercado (art. $9^{\circ}$, $\S 40$, da Lei no 6.385/76).

Ainda no exercício da competência fiscalizatória, a CVM poderá divulgar a instauração do procedimento investigativo que antecede a instauração de processo administrativo para aplicação de penalidades, quando o interesse público exigir.

Porém, a CVM não tem poderes para determinar o desfazimento de atos societários praticados pelos administradores e acionistas controladores das companhias 
abertas (ex.: alienação de controle, incorporação, fusão ou cisão de companhias abertas, compra e venda de ativos, etc.); e de determinar o ressarcimento de investidores prejudicados pelos atos ilegais e práticas não eqüitativas de administradores, membros do conselho fiscal e acionistas de companhias abertas; nem dos intermediários e dos demais participantes do mercado.

\section{b) Função Regulatória}

À CVM compete regulamentar as matérias expressamente previstas na Lei no 6.385/76 e na Lei no 6.404/76 (lei das sociedades por ações). Os atos normativos baixados pela CVM revestem-se da forma de Instruções (Deliberação CVM nº 01, de 1978).

\section{c) Função Registrária}

À CVM compete administrar os registros instituídos pela Lei $n^{0} 6.385$, ou seja, o registro de emissão pública de valores mobiliários (art. 19 da Lei no 6.385/76), sendo que o Art. 19, § 60, da Lei n 6.385 diz: "A Comissão poderá subordinar o registro a capital mínimo da companhia emissora e a valor mínimo da emissão, bem como a que sejam divulgadas as informações que julgar necessárias para proteger os interesses do público investidor".

A Instrução CVM no 400, 29/12/2003 dispõe sobre as ofertas públicas de distribuição de valores mobiliários, nos mercados primário ou secundário e o registro para negociação em bolsa ou em mercado de balcão (art. 21 da Lei no 6.385). Somente os valores mobiliários emitidos por companhia registrada na CVM podem ser negociados na bolsa e no mercado de balcão.

A Instrução CVM no 202, de 06/12/93 dispõe sobre o registro de companhia para negociação de seus valores mobiliários em Bolsa de Valores ou no mercado de balcão e a Instrução CVM n 270, de 23.01.1998 aborda o registro de companhia emissora de títulos ou contratos de investimento coletivo.

\section{d) Função Consultiva}

A Comissão de Valores Mobiliários manterá serviço para exercer atividade consultiva ou de orientação junto aos agentes do mercado de valores mobiliários ou a qualquer investidor valores mobiliários ou a qualquer investidor (art. 13 da Lei n 6.385/76) . Sendo que fica a critério na Comissão de Valores Mobiliários divulgar ou não as respostas às consultas ou aos critérios de orientação. 


\section{e) Função de Fomento}

Como agente de fomento do mercado financeiro, à CVM compete estimular a formação de poupanças e a sua aplicação em valores mobiliários; promover a expansão e o funcionamento eficiente e regular do mercado de ações, e estimular as aplicações permanentes em ações do capital social de companhias abertas sob controle de capitais privados nacionais (Lei no 6.385 , art. 40, incisos I e II).

Em seu site, a CVM apresenta este quadro que consolida alguns Pareceres de Orientação de sua emissão, que tratam de procedimentos contábeis e da divulgação de informações em notas explicativas e no relatório dos administradores, englobando, ainda, dois Ofícios-Circulares da Presidência.

ASSUNTO

Adiantamentos

Agências no Exterior - Consolidação

Ágio/Deságio - Amortização

Ajustes de Exercícios Anteriores

Aplicações em Ações - Atualização Monetária

Aplicações em Ouro

Apresentação dos Números em DF's

Arrendamento Mercantil

Ativação de Despesas Financeiras

Ativação de Encargos Financeiros

Ativo Contingente

Ativo Diferido

Atualização "Pro Rata" de Ativos e Passivos

Atualização

Financeiras

Avanços na Qualidade da Informação e PO.24/92

Divulgação das Demonstrações Contábeis

Capacidade Ociosa

Consistência

Contas a Receber $\mathrm{x}$ Resultado de Exercícios PO.21/90

Futuros

Contribuição Social

Correção Monetária Integral

Correça Monetária integral

Correção

Correção Monetária de Resultado Intermediários

Debêntures - Classificação Contábil

ASSUNTO

Demonstrações Consolidadas

PO.24/92

$P 0.21 / 90$

P0.17/89 $29 / 96$

/Prejuízo do OF-CIRC 578/85

PO.21/90

Ato da CVM
Ato da CVM

P0.15/87

PO.15/87

PO.15/87

OF-CIRC 578/85 309/86; PO.18/90

PO.21/90 e 22/91

$\mathrm{PO} .17 / 89$ e $\mathrm{PO} .18 / 90$

$\mathrm{PO} .17 / 89$ e PO.18/90

OF-CIRC 309/86 e PO.15/87

OF-CIRC $578 / 85$

OF-CIRC 309/86

PO.15/87

PO.17/89 PO.18/90

PO.18/90

OF-CIRC 309/86

PO.17/89; PO.18/90; PO.21/90; PO. 27/94e

OF-CIRC 309/86

OF-CIRC 309/86 
ASSUNTO

Ato da CVM

Demonstrações das Mutacões do Patrimônio OF-CIRC 309/86

Líquido

Demonstração das Origens e Aplicações de PO.15/87

Recursos

Demonstrações Financeiras do Exercício Anterior PO.15/87

(1986)

Diferimento do Resultado e Contratos com Pessoa PO.18/90

Jurídica de Direito Público

Discriminação das Participações nos Resultados $\quad \underline{\text { PO.04/79 }}$

Dividendos Obrigatórios - Política de Pagamento $\quad$ PO.21/90

Efeitos da Correção Monetária da Lei no. 8.200/91 PO.24/92

Empreendimentos em Fase de Implantação $\quad \underline{P O .17 / 89}$

Estoques, Correção Monetária

PO.24/92

Estoques, Critérios de Avaliação

Estrutura Conceitual Básica da Contabilidade

$\underline{\text { OF-CIRC } 578 / 85 \text { e } 309 / 86}$

OF-CIRC $309 / 86$

Imposto sobre a Renda na Fonte sobre Lucro $\underline{\text { PO.18/90 }}$

Líquido

Imposto sobre a Renda, Crédito Oriundo de PO.24/92

Prejuízo

Incentivos Fiscais

$\underline{P 0.21 / 90 e ~ 22 / 91}$

Indexador

PO.21/90e 22/91

Indices de Inflação para Novembro e Dezembro PO.24/92

de 1991

Investimentos Societários no Exterior

OF-CIRC $309 / 86$

Notas Explicativas

OF-CIRC 578/85 e 309/86, PO.15/87, PO.17/89,

PO.18/90e PO.24/92

Parecer do Auditor Independente

Pareceres de Auditoria, Ressalva nos

PO.24/92

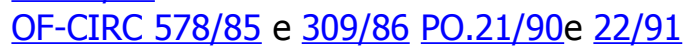

Pareceres dos Auditores e Postulado da PO.21/90

Continuidade

Participações Societárias

P0.17/89

Planos de Aposentadoria e Pensões

Programa de Desestatização

Programa de Estabilização Econômica

Provisão para Ajuste a Valor de Mercado

$\underline{P O .18 / 90}, \underline{P O} .21 / 90 \underline{P O} .24 / 92$

PO.24/92

OF-CIRC 309/86

Provisão para Créditos de Liquidação Duvidosa

PO.17/89

Provisão para Imposto de Renda e Incentivos OF-CIRC 309/86

Fiscais

Provisões para Passivos e Perdas Previstas com PO.18/90

Ativos

Receitas e Despesas Financeiras

Relatório da Administração

OF-CIRC $578 / 85$ e $309 / 86$

Reserva de Lucros a Realizar

Reserva de Reavaliação

PO.15/87 PO.17/89 PO.18/90

PO.15/87 PO.24/92

Resultados de Exercícios Futuros

Transações entre Partes Relacionadas

Valor Presente - Ajuste

Variação Cambial

OF-CIRC 578/85 e 309/86 PO.24/92

PO.17/89 OF-CIRC 578/85 e 309/86

OF-CIRC 309/86 PO.18/90

Voto Múltiplo

$0.21 / 90$ 22/91e PO.24/92

$\mathrm{PO} .13 / 87$

P0.24/92 


\section{Pareceres e instruções da CVM}

Para a esta tese, interessam os seguintes Pareceres de Orientação: PO No 04/79; PO No 13/87; PO No 15/87; PO No 17/89; PO No 18/90; PO No 21/90; PO No 24/92; 27/94; PO No 29/96; e Ofícios-Circulares CVM/PTE No 578/85 e No 309/86.

Trechos da INSTRUÇÃo CVM No 202, DE 06 DE DEZEMBRO DE 1993, com as alterações introduzidas pelas INTRUÇÕES CVM Nos 238/95, 245/96, 274/98, 309/99, 344/00, 351/01, 358/02 e 373/02.

\section{INSTRUÇÃO CVM No 202, DE 06 DE DEZEMBRO DE 1993.}

Dispõe sobre o registro de companhia para negociação de seus valores mobiliários em Bolsa de Valores ou no mercado de balcão, consolidando as Instruções CVM nºs. 60, de 14 de janeiro, 73, de 22 de dezembro, ambas de 1987, 118, de 7 de maio, e 127, de 26 de julho, ambas de 1990.

O Presidente da Comissão de Valores Mobiliários - CVM torna público que o Colegiado, em reunião realizada em 30 de novembro de 1993, com fundamento no disposto nos artigos 21 e 22, parágrafo único, inciso I, da Lei no 6.385, de 7 de dezembro de 1976, resolveu:

Art. $1^{0}$ - A negociação de valores mobiliários, emitidos por sociedades por ações, em Bolsas de Valores ou no mercado de balcão, depende de prévio registro da companhia na Comissão de Valores Mobiliários - CVM, de acordo com as normas previstas na presente Instrução.

Parágrafo único. O mercado de balcão compreende duas categorias: (NR)

a. o mercado de balcão organizado, cujos negócios são supervisionados por entidade auto-reguladora, com funcionamento autorizado pela Comissão de Valores Mobiliários, nos termos da Instrução CVM no 243, desta data; (NR)

b. o mercado de balcão não organizado, cujos negócios não são supervisionados por entidade autoreguladora. (NR)

○ Parágrafo único acrescentado pela Instrução CVM no 245, de $1^{\circ}$ de março de 1996.

Art. 20-O registro de companhia para a negociação de seus valores mobiliários no mercado de baleão não autoriza a negociação desses valores mobiliários em Bolsa de Valores.

Art. 20 -O registro de companhia para a negociação em um determinado mercado autoriza a negociação de seus títulos e valores mobiliários de renda variável exclusivamente nesse mercado.

- Artigo com redação dada pela Instrução CVM no 245, de 10 de março de 1996.

- $\quad$ Artigo revogado pela Instrução CVM no 344, de 17 de agosto de 2000.

- Vide art. $2^{\circ}$ da Instrução CVM no 344, de 17 de agosto de 2000.

Art. $3^{0}$ - Considera-se negociação de valores mobiliários no mercado de balcão a negociação feita fora das Bolsas de Valores, com a intermediação de bancos de investimentos, bancos múltiplos com carteira de investimento, sociedades corretoras, sociedades distribuidoras e agentes autônomos credenciados por essas instituições.-

Att. 40-O pedido de registro de companhia deverá ser submetido à CVM juntamente com o pedido de distribuição pública de valores mobiliários a que se refere o artigo 19 da Lei no 6.385, de 7 de dezembro de 1976, devendo o deferimento, se houver, abranger os dois pedidos. 
§10 A CVM poderá, a-seu critério, dispensar a apresentação concomitante de registro de distribuição pública devalores mobiliários prevista no "caput" deste artigo.

§ 20 As companhias abertas que já tiverem registro para negociação no mercado de bałcão e que desejarem obter registro para negociar seus valores mobiliários em Bolsa de Valores deverão enviar à CVM o documento previsto no inciso III do artigo 70 da presente Instrução.

Art. $4^{\circ}$ - O pedido de registro de companhia poderá ser submetido à CVM juntamente com o pedido de distribuição pública de valores mobiliários a que se refere o artigo 19 da Lei nº 6.385, de 7 de dezembro de 1976, devendo o deferimento, se houver, abranger os dois pedidos.

Parágrafo único. As companhias abertas que já tiverem registro para negociação no mercado de balcão e que desejarem obter registro para negociar seus valores mobiliários em Bolsa de Valores ou no mercado de balcão organizado deverão enviar à CVM o documento previsto no inciso III do art. $7^{\circ}$ da presente Instrução. (NR)

Artigo com redação dada pela Instrução CVM no 373, de 28 de junho de 2002.
ide Instrução CVM no 315, de 27 de setembro de 1999.

\section{DIRETOR DE RELAÇÕES COMO MERCADO}

\section{DIRETOR DE RELAÇÕES COM INVESTIDORES (NR)-}

Art. 50 - Para a companhia ser registrada na CVM, o estatuto social ou o Conselho de Administração deve atribuir a um diretor a função de relações como mercado, que poderá ou não ser exercida cumulativamente a outras atribuições executivas.

Art. $5^{\circ}$ - Para a companhia ser registrada na CVM, o estatuto social ou o Conselho de Administração deve atribuir a um diretor a função de relações com investidores, que poderá ou não ser exercida cumulativamente a outras atribuições executivas. (NR)

- $\quad$ Artigo com redação dada pela Instrução CVM no 309, de 10 de junho de 1999.

Art. 60-O diretor de relações com o mercado é responsável pela prestação de informações aos investidores, à EVM e, caso a companhia tenha registro em Bolsa de Valores, às bolsas, indicadas no artigo 13, bem comomanter atualizado o registro de companhia (artigos 13, 16 e 17).

Art. $6^{\circ}$ - O diretor de relações com investidores é responsável pela prestação de informações ao público investidor, à CVM e, caso a companhia tenha registro em bolsa de valores ou mercado de balcão organizado, a essas entidades, bem como manter atualizado o registro de companhia (arts. 13, 16 e 17). (NR)

- $\quad$ Artigo com redação dada pela Instrução CVM no 309, de 10 de junho de 1999.

\section{DOCUMENTOS NECESSÁRIOS À OBTENÇÃO DO REGISTRO DE COMPANHIA}

Art. 70 - O pedido de registro de companhia deverá ser instruído com os seguintes documentos:

I. a ata de reunião do Conselho de Administração ou da Assembléia-Geral que houver designado- diretor de relações com o mercado (artigo 50);

I. ata de reunião do Conselho de Administração ou da Assembléia Geral que houver designado o diretor de relação com investidores (art. $5^{\circ}$ );

○ Inciso I com redação dada pela Instrução CVM no 309, de 10 de junho de 1999.

II. requerimento assinado pelo diretor de relações com o mercado, contendo informações sobre:

II. requerimento assinado pelo diretor de relação com investidores, contendo informações sobre:

○ Inciso II com redação dada pela Instrução CVM no 309, de 10 de junho de 1999. 


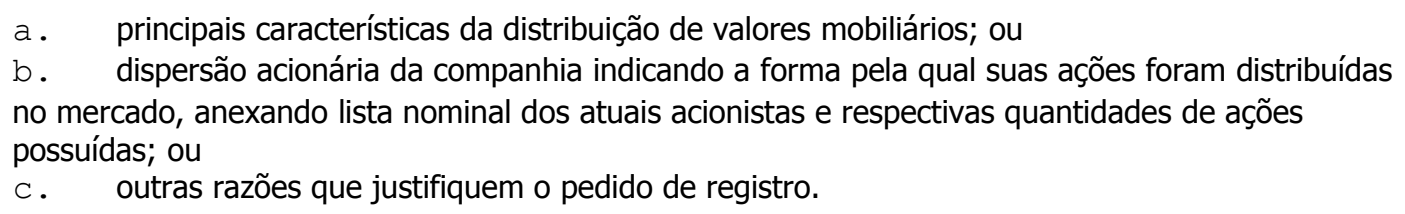

III. quando-se tratar de pedido de registro para negociação em Bolsa de Valores, declaração da Bolsainformando do deferimento do pedido de admissão à negociação dos valores mobiliários da companhia, condicionado apenas à obtenção do registro na-CVM;

III. quando se tratar de pedido de registro para negociação em Bolsa de Valores ou mercado de balcão organizado, declaração da entidade informando do deferimento do pedido de admissão à negociação do valor mobiliário da companhia, condicionado apenas à obtenção do registro na CVM; (NR)

\section{- Inciso III com redação dada pela Instrução CVM no 245, de $1^{\circ}$ de março de 1996.}

IV. exemplar atualizado do estatuto social;

V. demonstrações financeiras e notas explicativas previstas no artigo 176 da Lei n 6.404 , de 15 de dezembro de 1976, referentes aos três últimos exercícios sociais, indicando-se os jornais e as datas em que forem publicadas;

VI. demonstrações financeiras referentes ao último exercício social ou levantadas em data posterior ao encerramento do exercício social elaboradas em moeda de capacidade aquisitiva constante, nos termos da regulamentação emanada da CVM;

\section{○ Vide Instrução CVM no 248, de 29 de março de 1996.}

VII. relatório da administração referente ao último exercício social, elaborado de acordo com o artigo 133 da Lei no 6.404, de 15 de dezembro de 1976, e com o Parecer de Orientação CVM nº 15, de 28 de dezembro de 1987;

VIII. parecer do auditor independente, devidamente registrado na CVM, relativo às demonstrações financeiras do último exercício social (inciso V) e relativo as demonstrações financeiras referidas no inciso VI acima;

IX. demonstrações financeiras consolidadas, elaboradas de acordo com a legislação em vigor (Lei no 6.404/76, artigos 249 e 250, e regulamentação da CVM, e também em moeda de capacidade aquisitiva constante, acompanhadas de notas explicativas e de parecer de auditor independente, referentes ao último exercício social, ou levantadas em data posterior ao encerramento do mesmo, caso nesse período os investimentos adicionados aos créditos de qualquer natureza em controladas representem mais de trinta por cento do patrimônio líquido da companhia;

\section{- Vide Instrução CVM no 248, de 29 de março de 1996.}

X. demonstrações financeiras e, se for o caso, demonstrações consolidadas, acompanhadas de notas explicativas e parecer de auditor independente devidamente registrado na CVM, elaboradas de acordo com as disposições da Lei no 6.404/76 e em moeda de capacidade aquisitiva constante, levantadas em data que anteceder, no máximo, três meses o pedido de registro na CVM, quando:

○ Vide Instrução CVM no 248, de 29 de março de 1996.

a . o último exercício social for de doze meses e, na data do pedido de registro, já tiver transcorrido período igual ou superior a quarenta e cinco dias da data de encerramento do último exercício social;

b. o último exercício social compreender período superior a doze meses e a companhia ainda não tiver levantado as respectivas demonstrações financeiras;

c . o exercício social em curso compreender período superior a doze meses e, na data do pedido de registro, já tiver transcorrido período igual ou superior a doze meses.

IV. atas de todas as assembléias-gerais de acionistas, realizadas nos doze meses anteriores à data de registro na CVM;

V. fac-símile dos certificados de todos os tipos de valores mobiliários emitidos pela companhia ou, se for o caso, cópia do contrato mantido com instituição para execução de serviço de ações escriturais;

VI. quando se tratar de companhia em fase pré-operacional, estudo de viabilidade econômico-financeira do projeto, indicando, inclusive, os fatores de risco envolvidos no empreendimento, elaborado em data que anteceder em até três meses a entrada do pedido na CVM;

VII. formulário de Informações Anuais - IAN (artigos 22 e 23);

○ Vide art. $4^{\circ}$ da Instrução CVM no 346, de 29 de setembro de 2000.

IV . formulário de Demonstrações Financeiras Padronizadas - DFP apresentadas em moeda de capacidade aquisitiva constante (artigos 22 e 23);

$\mathrm{V}$. formulário de Informações Trimestrais - ITR contendo informações sobre os três primeiros trimestres do exercício social em curso, elaboradas em moeda de capacidade aquisitiva constante, desde que transcorridos mais de quarenta e cinco dias do encerramento de cada 
trimestre, acompanhadas de Relatório sobre Revisão Especial, emitido por auditor independente, devidamente registrado na CVM, consoante metodologia prevista no Comunicado Técnico - CT-IBRACON no 2, de 23 de julho de 1990, do Instituto Brasileiro de Contadores, aprovado pela Resolução CFC no 678, de 24 de julho de 1990, do Conselho Federal de Contabilidade (artigos 22 e 23).

- Vide art. 10, inciso I, alínea "b", e $2^{\circ}$ da Instrução CVM no 245, de $1^{\circ}$ de março de 1996, e arts. $4^{\circ}$ e $5^{\circ}$ da Instrução CVM no 346, de 29 de setembro de 2000.

\section{ATUALIZAÇÃO DO REGISTRO DE COMPANHIA}

Art. 13 - Concedido o registro, deverá a companhia adotar os seguintes procedimentos:

I. enviar à CVM, à bolsa em que seus valores mobiliários foram originalmente admitidos, à bolsa em que foram mais negociados no último exercício social e às outras bolsas que o solicitem informações periódicas e eventuais previstas nos artigos 16 e 17 desta Instrução nos prazos fixados; e

II. colocar as informações referidas no inciso I à disposição dos titulares de valores mobiliários, no departamento de acionistas da companhia; e

III. proceder à atualização, junto à CVM, dos seus dados cadastrais, até cinco dias após a ocorrência de qualquer alteração.

Parágrafo único. Os administradores deverão zelar pela divulgação simultânea para todo o mercado deinformações relevantes, inclusive relativas aos negócios da companhia, perspectivas de rentabilidade, vendas, comportamento de custos e de despesas, veiculadas por qualquer meio de comunicação ou em reuniões deentidades de classe, de modo a garantir a-sua ampla e imediata disseminação.

\section{○ $\quad$ Parágrafo único revogado pela Instrução CVM no 358, de 3 de janeiro de 2002.}

Art. 14. - As informações recebidas pela CVM serão colocadas à disposição do público, ressalvadas aquelas classificadas pela companhia como confidenciais.

§ 10 Poderá ser dispensada, a critério da CVM, a apresentação de informações periódicas e/ou eventuais, quando os administradores entenderem que sua revelação porá em risco interesse legítimo da companhia, aplicando-se, no que couber, as disposições do artigo 157, § 50, da Lei no 6.404, de 15 de dezembro de 1976, e da Instrução CVM no 31, de 8 de fevereiro de 1984.

$\S 20$ Se os administradores decidirem não revelar a informação, deverão apresentar as razões que os levaram a considerar que a revelação coloca em risco interesse legítimo da companhia.

$\S 3^{\circ}$ Quando as companhias remeterem à CVM informações confidenciais, deverão fazê-lo em documento apartado, enviado ao Presidente da CVM em envelope lacrado, no qual deverá constar a palavra "Confidencial".

Art. 15. - A CVM somente apreciará pedido de registro de emissão pública, ou qualquer outro pleito, de companhia que mantenha o registro atualizado, nos termos do artigo 13 desta Instrução.

\section{INFORMAÇÕES PERIÓDICAS}

Art. 16. - A companhia deverá prestar, na forma do artigo 13, desta Instrução, as seguintes informações periódicas, nos prazos especificados:

I. demonstrações financeiras e, se for o caso, demonstrações consolidadas, elaboradas de acordo com atei n0 6.404, de 15 de dezembro de 1976, e a regulamentação emanada da CVM para demonstrações financeiras em moeda de capacidade aquisitiva constante, acompanhadas do relatório da administração e do parecer do auditor independente:-

a. até um mês antes da data marcada para a realização da assembléia-geral ordinária; ou

b. no mesmo dia de sua publicação pela imprensa, ou de sua colocação à disposição dos acionistas, se esta ocorrer em data anterior à referida letra "a".

I. demonstrações financeiras e, se for o caso, demonstrações consolidadas, elaboradas de acordo com a Lei no 6.404, de 15 de dezembro de 1976, e a regulamentação emanada da CVM, acompanhadas do relatório da administração e do parecer do auditor independente: 
a. no prazo máximo de até três meses após o encerramento do exercício social; ou

b. no mesmo dia de sua publicação pela imprensa, ou de sua colocação à disposição dos acionistas, se esta ocorrer em data anterior à referida na alínea "a" deste inciso.

o Inciso I, alíneas "a" e "b", com redação dada pela Instrução CVM no 351, de 24 de abril de 2001.

o Vide Instrução CVM no 248, de 29 de março de 1996.

I I formulário de Demonstrações Financeiras Padronizadas-DFP, elaboradas em moeda de capacidade aquisitiva constante, nos mesmos prazos fixados no inciso I deste artigo;

II. formulário de Demonstrações Financeiras Padronizadas - DFP, nos mesmos prazos fixados no inciso I deste artigo;

- Inciso II com redação dada pela Instrução CVM no 351, de 24 de abril de 2001.

- Vide Instrução CVM no 248, de 29 de março de 1996.

III. edital de convocação da assembléia-geral ordinária, no mesmo dia de sua publicação pela imprensa;

IV. formulário de Informações Anuais - IAN, até trinta dias após a realização da assembléia-geralordinária;

IV. formulário de Informações Anuais - IAN: (NR)

a. no prazo máximo de cinco meses após o encerramento do exercício social; ou (NR)

b. no prazo máximo de um mês, a contar da data da realização da assembléia geral ordinária anual, se este prazo findar-se antes daquele estabelecido na alínea "a" deste inciso. (NR)

o Inciso IV, alíneas "a" e "b", com redação dada pela Instrução CVM no 351, de 24 de abril de 2001.

o Vide art. $4^{\circ}$ da Instrução CVM no 346, de 29 de setembro de 2000.

$V$. Sumário das decisões tomadas na assembléia-geral ordinária, no dia seguinte à sua realização;

VI . ata da assembléia-geral ordinária, até dez dias após a sua realização, com indicação das datas e jornais de sua publicação, se esta já tiver ocorrido;

VII . fac-símile dos certificados dos valores mobiliários emitidos pela companhia, se tiver havido alteração nos enviados anteriormente, até dez dias após a alteração;

VIII. formulário de Informações Trimestrais - ITR, elaboradas em moeda de capacidade aquisitiva constante, acompanhadas de Relatório de Revisão Especial (inciso XVI do artigo 70 desta Instrução) emitido por auditor independente devidamente registrado na CVM, até quarenta e cinco dias após o término de cada trimestre do exercício social, excetuando o último trimestre, ou quando a empresa divulgar as informações para acionistas, ou para terceiros, caso isso ocorra em data anterior.

0 Vide art. $1^{\circ}$, incisos I, alínea "b", e V, e $2^{\circ}$ da Instrução CVM no 245, de $1^{\circ}$ de março de 1996, Instrução CVM no 248, de 29 de março de 1996, e arts. $4^{\circ}$ e $5^{\circ}$ da Instrução CVM no 346, de 29 de setembro de 2000.

$\S 1^{\circ}$ Caso a companhia ainda esteja em fase pré-operacional deverá fornecer, juntamente com o formulário de Informações Anuais - IAN, informações atualizadas sobre o andamento do projeto apresentado à CVM por ocasião do pedido de registro.

$\S 2^{\circ}$ Caso a companhia tenha sido declarada falida, o síndico deverá prestar informações semestrais sobre prazos fixados, etapas atingidas, bens alienados, valores arrecadados, importâncias desembolsadas e outras informações consideradas relevantes para o mercado de valores mobiliários, até quarenta e cinco dias após o término do semestre.

$\S 3^{\circ}$ Caso a companhia entre em regime de liquidação extrajudicial as informações previstas no parágrafo anterior, deverão ser prestadas no prazo de quarenta e cinco dias após o término de cada trimestre do exercício social.

$\S 40$ Configura infração ao disposto no inciso IV deste artigo a não apresentação das informações anuais, em razão de não se ter realizado assembléia-geral ordinária no prazo estabelecido no artigo 132 da Lei n 6.404, de 15 de dezembro de 1976.

$\S 5^{\circ} \mathrm{Na}$ hipótese do parágrafo anterior, contar-se-ão os trinta dias fixados no inciso IV deste artigo da data do encerramento do prazo legal para a realização da assembléia-geral ordinária. 
§ $6^{\circ}$ As companhias poderão transmitir as informações previstas nos incisos III, V e VI deste artigo por fac-símile, ou telex, no qual constem os dados cadastrais do formulário Informações Periódicas e Eventuais - IPE, encaminhando-as nos referidos formulários padronizados, observados os prazos fixados.

$\S 70$ O formulário de Informações Anuais - IAN deverá ser atualizado sempre que se verificar a superveniência de quaisquer fatos que alterem informações prestadas na forma do inciso IV deste artigo, no prazo de dez dias, contados da data da ocorrência do fato. (NR)

\section{○ $\quad \xi 7^{\circ}$ acrescentado pela Instrução CVM no 351, de 24 de abril de 2001.}

\section{INFORMAÇÕES EVENTUAIS}

Art. 17. - A companhia deverá prestar, na forma do artigo 13 desta Instrução, as seguintes informações eventuais, nos prazos especificados:

I. edital de convocação de assembléia-geral extraordinária ou especial, no mesmo dia de sua publicação;

II. sumário das decisões tomadas nas assembléias-gerais extraordinária ou especial, no dia seguinte à sua realização;

III. ata de assembléia extraordinária ou especial, até 10 (dez) dias após a realização da assembléia;

IV. acordo de acionistas (artigo 118 da Lei no 6.404, de 15 de dezembro de 1976), quando do arquivamento na companhia;

V. convenção de Grupo de Sociedades (artigo 265 da Lei no 6.404, de 15 de dezembro de 1976), quando de sua aprovação;

VI. comunicação sobre ato ou fato relevante, nos termos do artigo 157, § 40, da Lei nº 6.404, de 15 de dezembro de 1976, e da Instrução CVM no 31, de 8 de fevereiro de 1984, no mesmo dia de sua divulgação pela imprensa;

VII. informação sobre pedido de concordata, seus fundamentos, demonstrações financeiras especialmente levantadas para obtenção do benefício legal e, se for o caso, situação dos debenturistas quanto ao recebimento das quantias investidas, no mesmo dia da entrada do pedido em juízo;

VIII. sentença concessiva da concordata, no mesmo dia de sua ciência pela companhia;

IX. informação sobre pedido ou confissão de falência, no mesmo dia de sua ciência pela companhia, ou do ingresso do pedido em juízo, conforme for o caso;

X. sentença declaratória de falência com indicação do síndico da massa falida, no mesmo dia de sua ciência pela companhia;

XI. outras informações solicitadas pela CVM, nos prazos que esta assinalar.

○ Vide Instrução CVM no 248, de 29 de março de 1996.

Parágrafo único. Para o encaminhamento das informações eventuais nos prazos fixados nos incisos I a XI deste artigo, aplicam-se as disposições constantes do $\S 6^{\circ}$ do artigo 16.-

Art. 18 - A companhia aberta que não mantiver seu registro atualizado, nos termos dos artigos 13,16 e 17 destaInstrução, ficará- sujeita à multa diária de 69,20 Unidades Fiscais de Referência Diária, sem prejúżo daresponsabilidade solidária dos administradores nos termos dos artigos 90, v, e 11 da Lei $n 06.385$, de 7 de dezembro de 1976.

Art. 18 - Sem prejuízo da responsabilidade dos administradores nos termos dos arts. 90 , $V$, e 11 da Lei no 6.385/76, com a redação dada pelo art. 20 da Lei no 9.457/97, a companhia aberta que não mantiver seu registro atualizado, nos termos dos arts. 13, 16 e 17 desta Instrução, ficará sujeita à multa cominatória diária, segundo os valores abaixo relacionados: (NR)

I. multa de $R \$ 500,00$ (quinhentos reais), pela não-apresentação das Demonstrações Financeiras, art. 16, inciso I; (NR)

II. multa de R\$500,00 (quinhentos reais), pela não apresentação das Demonstrações Financeiras Padronizadas - DFP-art. 16, inciso II; (NR)

III. multa de $R \$ 200,00$ (duzentos reais), pela não apresentação dos documentos e informações prevista no art. 16, incisos III a VII; (NR)

IV. multa de $R \$ 500,00$ (quinhentos reais), pela não apresentação das Informações Trimestrais - ITR - art. 16, inciso VIII; (NR)

V. multa de $R \$ 200,00$ (duzentos reais), pela não apresentação dos documentos e informações prevista no aft. 17 , incisos I a X. (NR) 
- Aftigo e incisos I a V com redação dada Instrução-GVM no 274, de 12 de março de1998.

Art.18 - Sem prejuízo da responsabilidade dos administradores nos termos dos arts. 90, inciso $\mathrm{V}$, e 11 da Lei no 6.385, de 7 de dezembro de 1976, com a redação que lhes foi dada pela Lei no 9.457, de 5 de maio de 1997, e pelo art. $2^{\circ}$ da Medida Provisória no 1.742-18, de 2 de junho de 1999, a companhia aberta que não mantiver seu registro atualizado, nos termos dos arts. 13, 16 e 17 desta Instrução, ficará sujeita à multa cominatória diária segundo as tabelas a seguir: (NR)

○ "Caput" com redação dada pela Instrução CVM no 309, de 10 de junho de 1999.

$\S 1^{\circ} \mathrm{O}$ patrimônio líquido será o apurado em 31 de dezembro do ano anterior ao da aplicação da multa cominatória. (NR)

\section{○ $\quad$ \& $1^{\circ}$ acrescentado pela Instrução CVM no 309, de 10 de junho de 1999.}

§ $2^{\circ}$ Caso não haja patrimônio líquido na data indicada no parágrafo anterior, ou o patrimônio líquido for negativo, a multa cominatória será cobrada pelo menor valor da respectiva tabela. (NR)

\section{○ $\quad \S 2^{\circ}$ acrescentado pela Instrução CVM no 309, de 10 de junho de 1999.}

Art. 19. - Configura infração grave para os fins previstos no §̧ 30 do artigo 11 da Lei no 6.385 , de 7 de dezembro de 1976, a transgressão às disposições desta Instrução e a não observância do prazo fixado no artigo 132 da Lei n0 6.404, de 15 de dezembro de 1976, para- a realização da assembléia-geralordinária.

Art. 19. Constitui infração de natureza objetiva, em que será adotado rito sumário de processo administrativo, de acordo com o Regulamento Anexo à Resolução CMN n 1.657/89, deixar de adotar, o administrador de companhia aberta, os procedimentos elencados nos incisos I a III do art. 13, ressalvada a hipótese prevista no inciso VI do art. 17 desta Instrução. (NR)

Parágrafo único. Configura infração grave, para os fins previstos no $\S 3^{\circ}$ do artigo 11 da Lei no 6.385 , de 07 de dezembro de 1976: (NR)

I. o descumprimento do disposto no inciso VI do artigo 17 desta Instrução; (NR)

II. a não-observância do prazo fixado no art. 132 da Lei no 6.404, de 15 de dezembro de 1976, para a realização da assembléia geral ordinária; (NR)

III. a reincidência das infrações de natureza objetiva definidas no "caput" deste artigo. (NR)

- Artigo e parágrafo único com redação dada Instrução CVM no 238, de 11 de outubro de 1995.

\section{DISPOSIÇÕES GERAIS}

Art. 22 - As informações periódicas e eventuais requeridas das companhias abertas, conforme disposto nos artigos 16 e 17 da presente Instrução, deverão ser apresentadas por meio eletrônico de acordo com estrutura- debanco de dados e programas fornecidos pela CVM, ou por formulários impressos padronizados.

Parágrafo único. As companhias poderão utilizar formulários contínuos desde que contenham todos os campose eonfiguração previstos nos formulários padronizados.

Art. 22 - Deverão ser apresentadas por meio magnético, de acordo com programas de computador fornecidos pela CVM, as seguintes informações: (NR)

I. Demonstrações Financeiras Padronizadas - DFP (art. 16, II); (NR)

II. Informações Anuais - IAN (art. 16, IV); (NR)

III. Informações Trimestrais - ITR (art. 16, VIII). (NR)

- "Caput" e incisos I a III com redação dada Instrução CVM no 274, de 12 de março de 1998. 
Art. 23. Ficam aprovados os seguintes formulários anexos e programas necessários para- oncaminhamento das informações por meio eletrônico:

a. Informações Anuais - IAN;

b. Informações Trimestrais - ITR;

c. Demonstrações Financeiras Padronizadas-DFP;

d. Informações Periódicas e Eventuais - IPE.

Art. 23. As demais informações periódicas e eventuais requeridas das companhias abertas deverão ser apresentadas impressas em papel A4, em duas vias.

- $\quad$ Artigo com redação dada Instrução CVM no 274, de 12 de março de 1998.

Parágrafo único. Fica autorizado o Superintendente Geral a alterar, incluir ou suprimir os formulários e programas aprovados por este artigo.

\section{Resumo de instruções relacionadas a esta pesquisa Instrução 358 de 03.01.2002}

Dispõe sobre a divulgação e uso de informações sobre ato ou fato relevante relativo às companhias abertas, disciplina a divulgação de informações na negociação de valores mobiliários e na aquisição de lote significativo de ações de emissão de companhia aberta, estabelece vedações e condições para a negociação de ações de companhia aberta na pendência de fato relevante não divulgado ao mercado, revoga a Instrução CVM No 31 , de 08.02.1984, a Instrução CVM No 69, de 08.09.1987, o art. 30 da Instrução CVM No 229, de 16.01.1995, o parágrafo único do art. 13 da Instrução CVM No 202, de 06.12.1993, e os arts. $3^{0}$ ao 11 da Instrução CVM No 299, de 09.02.1999, e dá outras providências. (Publicada no DOU de 28.01.2002 - págs. 14 e 15 - seção 1). ALTERADA PELA INSTRUÇÃO CVM No 369/02.

\section{Instrução 361 de 05.03.2002}

Dispõe sobre o procedimento aplicável às ofertas públicas de aquisição de ações de companhia aberta, o registro das ofertas públicas de aquisição de ações para cancelamento de registro de companhia aberta, por aumento de participação de acionista controlador, por alienação de controle de companhia aberta, para aquisição de controle de companhia aberta quando envolver permuta por valores mobiliários, e de permuta por valores mobiliários, REVOGA as Instruções CVM nºs 229/95, 299/99 e 345/00 e dá outras providências. (Publicada no DOU de 07.03.2002 - págs. 28 a 33 - seção 1).

\section{Instrução 391 de 16.07.2003}


Dispõe sobre a constituição, funcionamento e a administração dos fundos de investimento em participações. (Publicada no DOU de 18.07.2003 - pg. 11, 12 e 13 - Seção 1).

\section{Instrução 400 de 29.12.2003}

Dispõe sobre as ofertas públicas de distribuição de valores mobiliários, nos mercados primário ou secundário, e revoga a Instrução CVM no 13, de 30 de setembro de 1980, e a Instrução CVM no 88, de 3 de novembro de 1988. (Publicada no DOU de 09.01.2004 - pgs. 8 a 15 - Seção 1). REVOGA AS INSTRUÇÕES CVM NOS 13, DE 30.09.80 E 88, DE 03.11.88. 


\section{Cartilha da Associação Nacional de Investidores do Mercado de Capitais - ANIMEC}

Revista RI no. 61 , março 2003 p. 14

A GOVERNANÇA TEM QUE SER EXERCIDA DE FATO

por Gregorio Mancebo Rodriguez

vicepresidente da ANIMEC - Associação Nacional de Investidores do Mercado de Capitais.

(e-mail: animec@animec.com.br)

A Associação Nacional de Investidores do Mercado de Capitais - ANIMEC elaborou uma cartilha com 22 itens que, na visão dos investidores não controladores (chamados de minoritários), podem agregar maior valor às ações das empresas de Capital Aberto no Brasil. A proposta da cartilha surgiu tendo em vista a análise dos principais problemas enfrentados pelos investidores nos últimos anos. "Não basta as empresas adotarem regras de transparência e de Governança Corporativa, a 'Governança' tem que ser exercida de fato".

\section{CARTILHA DA ANIMEC \\ COMO OS ACIONISTAS NÃO CONTROLADORES (MINORITÁRIOS) OLHAM AS EMPRESAS QUE AGREGAM VALOR AO ATIVO AÇÃO}

A ANIMEC foi fundada há três anos e, desde então, participou, direta ou indiretamente, de mais 70 casos, relativos a ofertas públicas, fechamentos de capital, permutas de ações, permutas por BDR, aumentos de capital, etc. Fazendo uma breve análise dos problemas que sugiram neste período, e considerando sugestões de associados, discussões em seminários, etc., gostaríamos recomendar, na visão da ANIMEC, quais são principais pontos para a empresa alcançar, na prática, melhores níveis de disclosure / governança corporativa / transparência / etc.

1) Conselho de Administração - A nomeação de um Conselheiro representante dos minoritários dá indicação de que os rumos que a empresa pretende seguir estão em consonância com os seus objetivos sociais, e que a função deste Conselheiro será a defesa dos direitos e interesse dos minoritários (vide Enron);

2) Conselho Fiscal - A nomeação de um Conselheiro representando os minoritários favorece a fiscalização da execução, pela Diretoria, das decisões tomadas pelo Conselho de 
Administração, pondo em prática os melhores princípios de governança corporativa, o que agrega valor ao ativo AÇÃO;

3) Política de Relações com Investidores - Manutenção de um comitê de relações com investidores, para disseminar as práticas de governança instituídas pelo IBGC, CVM e ANIMEC;

4) Relacionamento com Investidores - Teleconferência - A ANIMEC está implantando, em parceria com a Thomson, um serviço de Teleconferências direcionado aos investidores, gestores de fundos, assets;

5) Tag Along - A inclusão, nos estatutos, do tag along de $100 \%$, dá maior segurança e confiança ao investidor quanto ao tratamento equânime em eventual venda do controle acionário;

6) Site para Investidores - Interativo, possibilitando acesso em tempo real às informações, fazendo com que boatos se dissipem, e números e informações estejam disponibilizados para todos os acionistas no mesmo tempo, inibindo o surgimento de situações de inside trade e inside information;

7) Agregar Valor - Divulgar instrumentos técnicos de avaliação, do tipo E.V.A.,que são de fundamental importância para verificar a criação de valor na companhia;

8) Câmara de Arbitragem - A inclusão, nos estatutos, da aceitação da Câmara de Arbitragem do Novo Mercado para resolução de eventuais conflitos, demonstra a seriedade da empresa no tratamento da matéria, e facilidade de solução em eventual demanda;

9) Níveis 1 e 2 e Novo Mercado - A inclusão nos níveis de maior transparência, ou definir e divulgar a estratégia para atingi-los, demonstra aos investidores a preocupação da empresa com o disclosure;

10) Rating - Disponibilização, para investidores, das avaliações a serem realizadas periodicamente;

11) Proporcionalidade entre ações ON /PN - Voto - A substituição das ações PN por ON (total ou parcial), e a possibilidade de voto extensivo aos preferencialistas, dará maior tranqüilidade ao investidor na escolha da aplicação;

12) ADR - A utilização desta prática, e seu beneficio na captação de recursos, bem como sua adequação, mostram a intenção de globalização da empresa no setor;

13) Contabilidade - Adequação aos padrões contábeis globais concede maior transparência e segurança quanto à veracidade das informações;

14) Valor Econômico - A utilização do critério do valor econômico para a avaliação do valor efetivo da empresa, evitará que, em futuras demandas (OPAs, troca de controle, etc.), sejam utilizados critérios legais, porém não justos, como o valor patrimonial e a cotação de 
mercado, para reembolso aos acionistas, enquanto a "mais valia" fica, na sua totalidade, nas mãos dos controladores;

15) Prêmio de Sinergia - Quando ocorrerem reestruturações, este prêmio deve ser dividido entre todos os participantes (ON e PN);

16) Split / Implit - Devem ser implementadas quando necessário, para facilitar a negociação e aumentar a liquidez, evitando variações descabidas nas cotações;

17) Base Acionária - Pulverizar e aumentar a base, para facilitar a negociação das ações;

18) Compra de Ações para Tesouraria - Quando houver disponibilidade de caixa e a precificação das ações for considerada inadequada, tendo em vista a realidade econômicofinanceira da empresa;

19) Venda de Ativos - Não ligados à atividade do negócio da empresa;

20) Gestão - Focando crescimento de receita, vantagens competitivas e melhoria de margens, como plano estratégico definido;

21) Dividendos - Política de pagamento acima da média da concorrência / mercado;

22) Aquisições - Realização de novas aquisições dentro do foco da empresa e de seu plano estratégico de crescimento.

Os pontos elencados traduzem para o Investidor, na prática, o que significa Governança Corporativa, as medidas que agregam valor à ação e a sua efetiva transparência.

Estes pontos devem ser seguidos por todas as empresas, de capital aberto ou não, as familiares ou governamentais, para termos uma economia mais dinâmica e um mercado de capitais mais consistente e confiável. 